\title{
JEFERSON STRAATMANN
}

Redes voltadas para produtos florestais não madeireiros - análise da influência de redes de cooperação nas cadeias de valor da Terra do Meio no Pará 



\section{JEFERSON STRAATMANN}

\section{Redes voltadas para produtos florestais não madeireiros - análise da influência de redes de cooperação nas cadeias de valor da Terra do Meio no Pará}

Tese de Doutorado apresentada à Escola de Engenharia de São Carlos da Universidade de São Paulo para a obtenção do Título de Doutor em Engenharia de Produção.

Orientador: Prof. Dr. Luiz Cesar Ribeiro Carpinetti 
AUTORIZO A REPRODUÇÃO TOTAL OU PARCIAL DESTE TRABALHO, POR QUALQUER MEIO CONVENCIONAL OU ELETRÔNICO, PARA FINS DE ESTUDO E PESQUISA, DESDE QUE CITADA A FONTE.

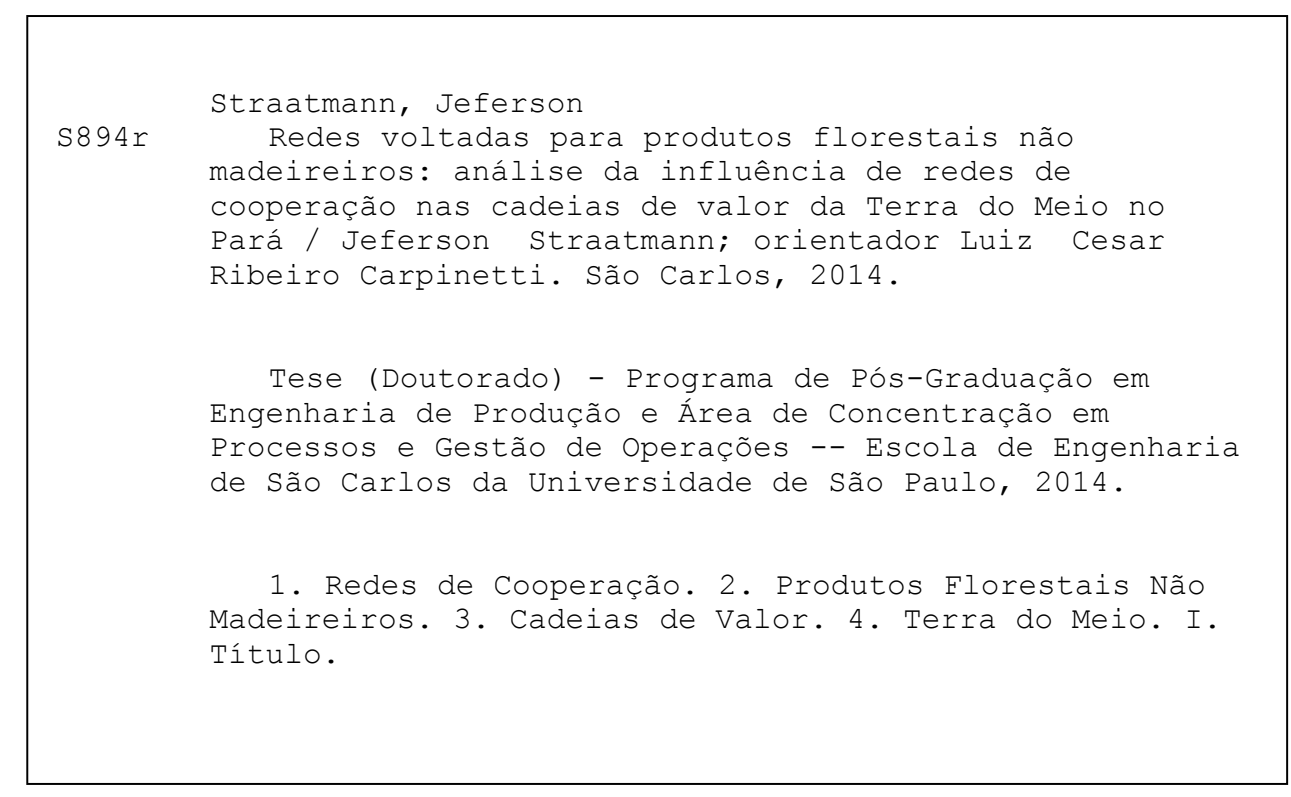




\section{FOLHA DE JULGAMENTO}

Candidato: Engenheiro JEFERSON STRAATMANN.

Título da tese: "Redes voltadas para produtos florestais não madeireiros - análise da influência de redes de cooperação nas cadeias de valor da terra do meio do Pará".

Data da defesa: 23/09/2014

\section{Comissão Julgadora:}

Prof. Titular Luiz Cesar Ribeiro Carpinetti (Orientador)

(Escola de Engenharia de São Carlos/EESC)

Prof. Dr. Mateus Cecilio Gerolamo

(Escola de Engenharia de São Carlos/EESC)

Prof. Associado Fabio Muller Guerrini

(Escola de Engenharia de São Carlos/EESC)

Prof. Dr. Mário Sacomano Neto

(Universidade Federal de São Carlos/UFSCar)

Profa. Dra. Carla Morsello

(Escola de Artes, Ciências e Humanidades - EACH/USP)

\section{Resultado:}

APROVADO

APRONADO

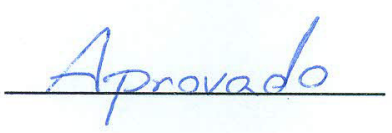

APROUADO

APROVADO

Coordenador do Programa de Pós-Graduação em Engenharia de Produção Prof. Titular Luiz Cesar Ribeiro Carpinetti

Presidente da Comissão de Pós-Graduação:

Prof. Associado Paulo César Lima Segantine 

A meus amigos, familiares e especialmente à minha amada esposa, com quem divido sonhos, suor, alegrias e tristezas. Juntos somos muito mais do que dois. 



\section{AGRADECIMENTOS}

"Uma pessoa só é uma pessoa através de outras pessoas". Assim, através dessa máxima dos povos Zulu e Xhosa, inicío meus agradecimentos. Minha existência como pessoa, meu trabalho, minha forma de ser e entender o mundo é parte das relações construídas ao longo de minha vida, sendo essas pessoas parte da minha existência e parte do meu reconhecimento como humano. Especialmente para a elaboração da tese, algo cartesiano e individual, as relações, as amizades e o companheirismo foram fundamentais tanto para seu início, quanto para o desenvolver, quanto para sua finalização.

Assim, agradeço primeiramente aos amigos das Resex e Terras Indígenas da Terra do Meio e Xingu, com os quais venho aprendendo cada vez mais sobre as relações humanas e de como somos parte integrantes da natureza, podendo nos reconhecer na mesma. Agradeço também aos amigos das diferentes instituições que lutam na Terra do Meio e Xingu por um país mais democrático, que reconheça o valor das Populações Tradicionais e Indígenas para a humanidade, e que garanta direitos adequados à realidade dos mesmos.

Agradeço aos professores Carpinetti e Mateus pela confiança e apoio e pela liberdade de pesquisar um tema desafiador, que ultrapassa os limites de conhecimento da Engenharia de Produção, trazendo novos entendimentos e possibilidades para a área.

Agradeço a meus amigos mais próximos pelo companheirismo e dedicação, especialmente nas horas mais difíceis.

Agradeço finalmente a meus pais Gilberto e Dinalva, minha irmã Gisele e minha esposa Carolina pelo amor compartilhado. 



\section{RESUMO}

STRAATMANN, J. Redes voltadas para produtos florestais não madeireiros análise da influência de redes de cooperação nas cadeias de valor da Terra do Meio no Pará. 2014. 225 f. Tese (Doutorado) - Departamento de Engenharia de Produção, Escola de Engenharia de São Carlos - Universidade de São Paulo, São Carlos, 2014.

Os Produtos Florestais Não Madeireiros (PFNM) são entendidos como uma fonte importante de renda agregada às atividades de subsistência das populações moradoras de áreas protegidas. Porém, a governança de seus territórios e cadeias é complexa, contemplando diferentes pressões, ilegalidades, interesses e organizações. Com base nesse contexto, as teorias relacionadas à governança florestal e de cadeias de valor de PFNM apontam para a necessidade de criação de ambientes multistakeholders para promover parcerias e melhorias na governança de territórios e cadeias. A teoria de Redes de Cooperação trazem elementos de organização e estruturação de processos cooperativos para a promoção de setores econômicos em diferentes realidades, podendo contribuir também para o entendimento e melhoria de redes voltadas para a promoção de cadeias de valor de PFNM. O estudo de caso realizado na Rede Terra do Meio (RTM) possibilitou o entendimento das contribuições das redes de cooperação para a melhoria da governança das cadeias de valor de PFNM. Percebe-se que a organização em rede na Terra do Meio permitiu a estruturação de processos de melhoria e monitoramento de cadeias de valor de PFNM com base em subredes organizadas pelo tripé "grupos extrativistas - grupos interinstitucionais - organizações de mercado" em paralelo a ações direcionadas ao acesso a políticas públicas, proteção do território, educação e saúde. Essas subredes de operação de melhorias são ligadas a ambientes mais amplos de promoção da cooperação interinstitucional, como a RTM, que potencializam o diálogo, planejamento, monitoramento e coordenação de processos cooperativos no território. A cooperação interinstitucional em rede observada na Terra do Meio contribuiu para o ganho de confiança nas relações entre as comunidades, instituições, organizações de mercado e financiadores, potencializando laços, ações conjuntas e obtenção de recursos. A presente tese 
apresenta a descrição do funcionamento da Rede Terra do Meio, suas subredes e cadeias de valor, analisando o funcionamento da rede como um todo em paralelo às teorias de redes de cooperação encontradas na literatura, buscando entendimento sobre os processos de governança e as influências sobre as cadeias de valor de PFNM. De forma complementar os aprendizados da pesquisa são sistematizados como diretrizes de governança, que visam facilitar o entendimento e melhoria do processo de cooperação na Terra do Meio e em territórios com características semelhantes.

Palavras-chave: Redes de Cooperação; Produtos Florestais Não Madeireiros; Cadeias de Valor; Terra do Meio. 


\section{ABSTRACT}

STRAATMANN, J. Networks focused on non-timber forest products - Analysis of the influence of cooperation networks in the value chains of Terra do Meio in Para. 2014. 225 f. Thesis (Ph.D.) - Department of Production Engineering, São Carlos School of Engineering - University of São Paulo, São Carlos, 2014.

Non-Timber Forest Products (NTFPs) are seen as an important source of income combined with livelihood activities of protected areas population. However, the governance of their territories and chains is complex, beholding different pressures, illegalities, interests and organizations. Based on this context, theories related to forest governance and NTFP value chains point to the need to create environments to promote multi-stakeholder partnerships and improvements in governance of territories and chains. The Cooperation Networks theory brings organization and structuring elements of cooperative processes for the promotion of economic sectors in different realities, contributing also to the understanding and improvement of networks focused on the promotion of NTFP value chains. The case study in Rede Terra do Meio (RTM) enabled the understanding of the cooperation networks contributions to the NTFPs value chains governance. It is noticed that the network organization in Terra do Meio allowed the structuring of process improvement and monitoring of NTFP value chains based on subnetworks organized by the tripod "extractivist groups - interinstitutional groups - market organizations" in parallel with targeted actions to access public policies, territorial protection, education and health. These subnetworks directed to improvements operation are linked to broader environments of interinstitutional cooperation promotion, such as RTM, which enhance dialogue, planning, monitoring and coordination of cooperative processes in the territory. interinstitutional cooperation observed in Terra do Meio network contributed to gain trust among communities, institutions, market and financing organizations, enhancing ties, joint actions and resourcing. This thesis presents a description of Terra do Meio network, its subnetworks and value chains, analyzing the functioning of the network as a whole in parallel to cooperation networks theories found in literature, seeking the understandin of governance processes and the influences on NTFP value chains. Complementarily, the research 
learnings are systematized as governance guidelines, which are intended to facilitate the understanding and improvement of cooperation processes at Terra do Meio and at territories with similar characteristics.

Keywords: Cooperation Networks; Non Timber Forest Products; Value Chains; Terra do Meio. 


\section{LISTA DE FIGURAS}

Figura 1: Terra do Meio. 26

Figura 2: Fases da Pesquisa. 33

Figura 3: Estrutura de gestão da rede Ecovida. 58

Figura 4: Papéis e organização da rede Ecovida. 58

Figura 5: Selo Empório do Cerrado. 60

Figura 6: Estrutura de Gestão Rede de Comercialização do Cerrado. 63

Figura 7: Estrutura político-administrativa do PNPSB. 68

Figura 8: Redes Colaborativas. 74

Figura 9: Fases do Ciclo de Vida de Redes Colaborativas. 83

Figura 10: O ciclo de vida do cluster. 84

Figura 11: Gestão de desempenho de clusters industriais e redes de cooperação empresarial.

Figura 12: Gestão de redes cooperativas.

Figura 13: Mapa do Fluxo de Valor da Castanha em 2010

Figura 14: Mapa do Fluxo de Valor da Castanha com Cantinas em 2014......115

Figura 15: Estrutura de Governança das redes e cadeias de valor da Terra do Meio. 157

Figura 16: Ciclo de processos de governança de Redes de Cooperação 189

Figura 17: Subredes de melhoria e monitoramento das cadeias. 197 



\section{LISTA DE QUADROS}

Quadro 1: Fontes de evidências - pontos fortes e pontos fracos.....................32

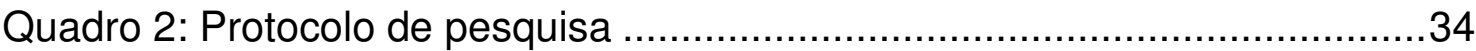

Quadro 3: Perspectivas teóricas para redes interorganizacionais. ..................71

Quadro 4: Pontos de caracterização e análise de redes de cooperação...........76

Quadro 5: Ontologia de estruturas de gestão de redes de cooperação. ...........80

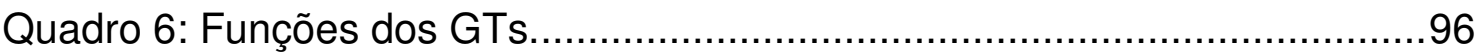

Quadro 7: Participação das Instituições na Rede da Terra do Meio.................97

Quadro 8: Comparação entre valores de mercadorias cobrados pelo regatão e nas cantinas das Resex.

Quadro 9: Síntese da análise do estudo de caso da RTM. 



\section{LISTA DE SIGLAS}

APL - Arranjo Produtivo Local

APA - Área de Proteção Ambiental

ADR - Agência de Desenvolvimento Regional

BNDES - Banco Nacional de Desenvolvimento Econômico e Social

CNO - Collaborative Network Organization

CNS - Conselho Nacional dos Seringueiros

CONAB - Companhia Nacional de Abastecimento

CPR - Certificação Participativa em Rede

CPT - Comissões Pastorais da Terra

Esec - Estação Ecológica

FES - Floresta Estadual

FLONA - Floresta Nacional

Funai - Fundação Nacional do Índio

GIZ - Cooperação Técnica Alemã

GTZ - Cooperação Técnica Alemã

IBGE - Instituto Brasileiro de Geografia e Estatística

ICMBio - Instituto Chico Mendes de Conservação da Biodiversidade

Ideflor - Instituto de Desenvolvimento Florestal do Pará

Imaflora - Instituto de Manejo e Certificação Florestal e Agrícola

Incra - Instituto Nacional de Colonização e Reforma Agrária 
Ipam - Instituto de Pesquisa da Amazônia

ISA - Instituto Socioambiental

MAPA - Ministério da Agricultura, Pecuária e Abastecimento

MDA - Ministério do Desenvolvimento Agrário

MDS - Ministério do Desenvolvimento Social e Combate à Fome

MDTX - Movimento de Defesa da Transamazônica e Xingu

MMA - Ministério do Meio Ambiente

NR - Núcleos Regionais

ONG - Organização Não Governamental

Opac - Organismo Participativo de Avaliação de Conformidade

Parna - Parque Nacional

PPG7 - Programa Piloto para a Proteção das Florestas Tropicais do Brasil

VBE - Virtual Breeding Environment

VE - Virtual Enterprise

VO - Virtual Organization

PAA - Programa de Aquisição de Alimentos

PDA - Projetos Demonstrativos Agroextrativistas

PDS - Projetos de Desenvolvimento Sustentável

PFNM - Produtos Florestais Não Madeireiros

PGPM - Programa de Garantia do Preço Mínimo

PME - Pequena e Média Empresa 
PNAE - Programa Nacional de Alimentação Escolar

PPG7 - Programa Piloto para a Proteção das Florestas Tropicais do Brasil

PNPSB - Plano Nacional de Promoção das Cadeias dos Produtos da Sociobiodiversidade

Resex - Reservas Extrativistas

RDS - Reserva de Desenvolvimento Sustentável

RTM - Rede Terra do Meio

SAGRI - Secretaria da Agricultura do Estado do Pará

Snuc - Sistema Nacional de Unidades de Conservação

SPG - Sistema Participativo de Garantia

TI - Terra Indígena

UC - Unidade de Conservação

UEBT - União para Biocomércio Ético

WWF - World Wild Foundation 



\section{SUMÁRIO}

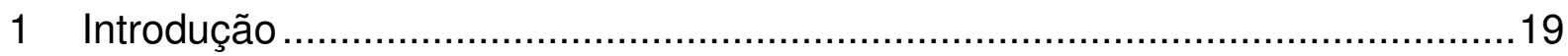

1.1 Contextualização e Problema de Pesquisa ......................................19

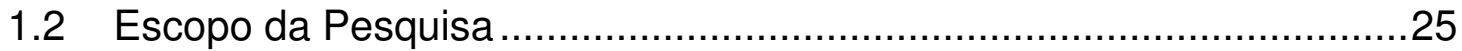

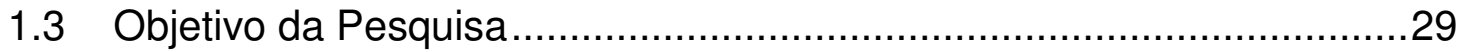

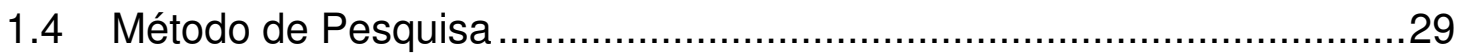

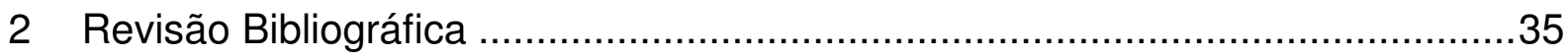

2.1 Produtos Florestais Não Madeireiros e Populações Tradicionais...........35

2.1.1 Histórico das Cadeias de Valor de PFNM …….............................37

2.1.2 A Organização Extrativista ...................................................... 40

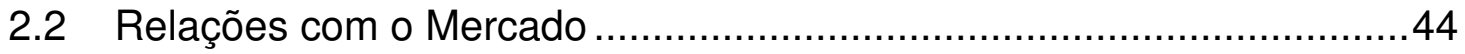

2.2.1 Relações empresas e comunidades ……….............................45

2.2.2 Relações na cadeia de valor .......................................................50

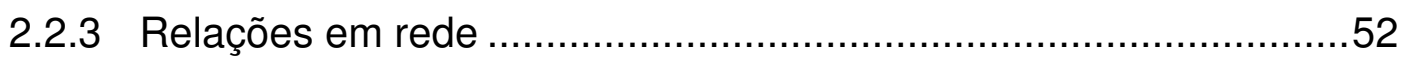

2.3 Plano Nacional de Promoção das Cadeias da Sociobiodiversidade......64

2.4 Redes de Cooperação ................................................................. 70

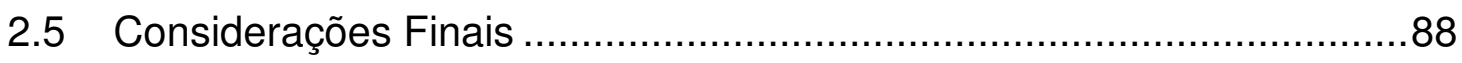

3 Estudo de Caso - Rede Terra do Meio ............................................................

3.1 Histórico da Rede Terra do Meio e Antecedentes de Cooperação.........93

3.2 O GT de atividades produtivas e o processo de planejamento das cadeias de valor da Terra do Meio .98

3.3 Produtos e Cadeias de Valor. 
3.3.1 Introdução e contextualização das cadeias e ações regionais .... 109

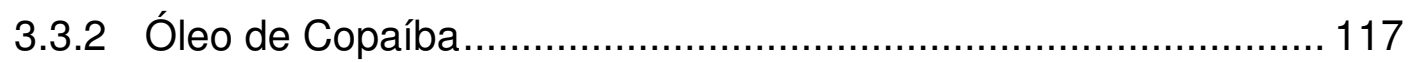

3.3.3 Borracha Natural.............................................................. 120

3.3.4 Castanha do Pará …............................................................... 126

3.3.5 Mini-usinas de PFNM ........................................................... 132

4 Análise da Rede Terra do Meio .............................................................. 144

4.1 Evolução e Ciclo de Vida da Rede .................................................... 144

4.2 Estrutura de Governança e Coordenação da RTM ............................ 147

4.3 Funcionamento da rede e das subredes da Terra do Meio.................. 157

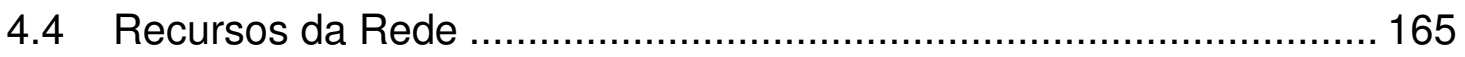

4.5 Influências nas cadeias de PFNM ................................................... 168

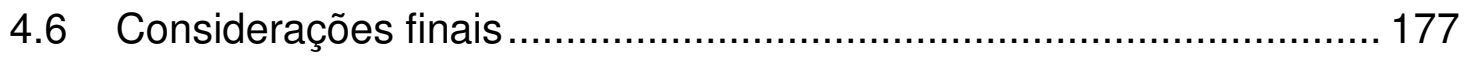

5 Diretrizes para estruturação de redes de cooperação voltadas para as cadeias

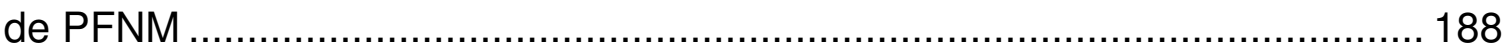

5.1 Mobilização e estruturação da rede ................................................. 189

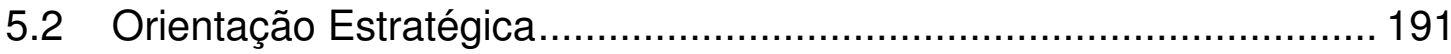

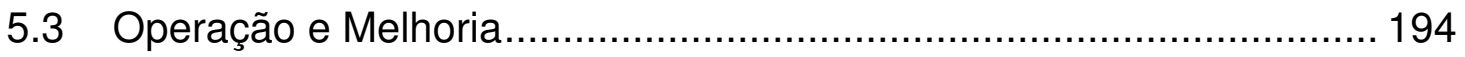

5.4 Monitoramento / Avaliação ................................................................ 199

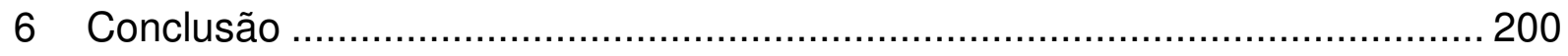

7 Limitações e sugestões para trabalhos futuros ............................................ 210

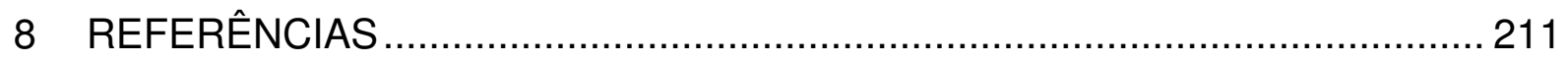

APÊNDICE A - Atividades, métodos e cronograma de campo …........................ 222 


\section{Introdução}

\subsection{Contextualização e Problema de Pesquisa}

As questões socioambientais e de sustentabilidade nas relações de mercado vêm ganhando força e adesão da população e das empresas. O aquecimento global e seus possíveis impactos, a poluição, a qualidade dos alimentos, as relações comerciais e de trabalho, assim como o modo de vida e o conhecimento tradicional, ganham cada vez mais visibilidade e passam a ser fatores de influência sobre o consumo de mercadorias e constituição de cadeias. Estes fatores estão levando governos a adotarem legislações mais restritivas e empresas a buscarem práticas de produção que aparentam ser mais dignas em termos sociais e ambientais (MORSELLO, 2006; BUTLER; LAURENCE, 2008; LE TOURNEAU; GREISSING, 2010).

A busca por produtos e cadeias produtivas socioambientalmente comprometidas traz possibilidades de mercados diferenciados para empreendimentos de base comunitária e empresas. No setor de cosméticos, por exemplo, há uma demanda crescente por produtos e matérias-primas oriundas de fontes naturais, extraídas de forma sustentável e que fortaleçam as comunidades que moram dentro destes ecossistemas (MORSELLO, 2006; LE TOURNEAU; GREISSING, 2010).

Para a produção e comercialização dos Produtos Florestais Não Madeireiros (PFNM) ou produtos da sociobiodiversidade ${ }^{1}$, as empresas necessitam de uma grande rede de fornecedores para atenderem a suas demandas, com cadeias que

1 "Bens e serviços (produtos finais, matérias primas ou benefícios) gerados a partir de recursos da biodiversidade, voltados à formação de cadeias produtivas de interesse dos povos e comunidades tradicionais e de agricultores familiares, que promovam a manutenção e valorização de suas práticas e saberes, e assegurem os direitos decorrentes, gerando renda e promovendo a melhoria de sua qualidade de vida e do ambiente em que vivem." (BRASIL, 2009a, p. 9). 
contemplem diferentes níveis de intermediários. É comum que as relações nestas cadeias sejam informais e algumas vezes ilegais (JENSEN, 2009), com exploração dos extrativistas neste processo (BELCHER; RUÍZ-PÉRES; ACHDIAWAN, 2005; TE VELDE et al., 2006; NKEM et al., 2010).

Os extrativistas fazem parte de diferentes grupos étnicos e formas de organização social (seringueiros, quilombolas, ribeirinhos, camponeses, indígenas etc.), sendo que parte desses grupos é reconhecida pela legislação Federal como Povos Tradicionais (BRASIL, 2007), Indígenas e Quilombolas. Em sua vida na floresta, estas populações desenvolveram estratégias próprias de relação interna, de relação com a floresta e de relação com o mercado, que são mais abrangentes que relações meramente comerciais e financeiras (ALMEIDA, 2004; ANDRADE; MATTOS; ARAÚJO, 2008; GUERRERO; FURIER; TORRES, 2009; TORRES, 2011; WOORTMANN, 2001).

A relação das populações tradicionais amazônicas com os mercados mercantilistas, capitalistas e com as cadeias de PFNM começa com os primeiros contatos com os colonizadores e se desenvolve durante os diferentes momentos econômicos da região (ALMEIDA, 2004; DE SARTRE; TARAVELLA, 2009; RIBEIRO D., 1995). O mercado da borracha, em especial, foi um dos mais influentes e trouxe uma nova população e crescimento econômico para a Região Norte. Com a abrupta queda de preços, por volta de 1913, a população diretamente ligada à economia gomífera passa a se especializar nas dinâmicas florestais (ALMEIDA, 2004).

Após a borracha, outras atividades econômicas mais predatórias se estabeleceram na região amazônica em diferentes ciclos, principalmente, a madeira, a pecuária e a especulação fundiária. Essas atividades aumentaram o impacto sobre as populações tradicionais, por meio da grilagem de terras, expulsão dos povos de seus territórios, migração e um grande processo de desmatamento reforçado pela política integracionista dos militares (FEARNSIDE, 2003; ALMEIDA, 2004, SALISBURY; SCHMINK, 2007; DE SARTRE; TARAVELLA, 2009).

Os processos de desmatamento e invasão de territórios colaboraram para 0 surgimento de movimentos sociais de luta pelos direitos destas populações, com 
aumento da atenção nacional e internacional para a Amazônia (ALMEIDA, 2004). Esta luta resultou na conquista de alguns direitos, especialmente 0 de reconhecimento territorial por meio da criação de áreas protegidas de uso sustentável e de uso comum (ALMEIDA, 2004; FEARNSIDE, 2003).

De Sartre e Taravella (2009) analisam o momento histórico de transição de um projeto desenvolvimentista militar para um projeto socioambiental e de conservação da floresta. Nesse processo, dividem-se instituições e projetos que apoiam e defendem as diferentes perspectivas e se desenvolve, na região amazônica, um sistema de governança forte, interligado e complexo. Esse sistema pode tanto apoiar quanto inibir ações nas cadeias dos diferentes produtos regionais.

Buscando contemplar a complexidade institucional e de gestão de florestas na Amazônia, Ros-Tonen et al. (2008) avaliam que as parcerias em suas diferentes perspectivas são o caminho mais apropriado para a melhoria da gestão e manejo florestal, e concluem que há,

Primeiro, a necessidade de lidar com um número cada vez maior de atores na gestão e governança florestal; segundo, um aumento no escopo da gestão florestal, com a necessidade de maior atenção aos objetivos sociais e aos PFNM; e, terceiro, a necessidade de lidar com questões mais amplas que a gestão de uma unidade em si, sendo preciso criar um contexto político, legal e institucional apropriado (ROS-TONEN et al., 2008, p. 1495).

Ros-Tonen et al. (2008) apontam a necessidade de arranjos institucionais equitativos, com boa relação custo-benefício e organização intermediária flexível, capazes de mediar as partes buscando baixos custos de transação. Na visão dos autores é necessária a inclusão de brokers, com uma função de controladores e guardiões da parceria, podendo ser constituídos pelo governo e por terceiros, intervindo quando necessário e orientando empresas e comunidades.

O conceito de broker é encontrado também na literatura de redes de cooperação, sendo definido como um agente, institucional ou não, que tem o papel de articular projetos, ações, relações com o mercado, novos negócios e empreendimentos coletivos que atendam a objetivos e princípios compartilhados 
(CAMARINHA-MATOS; AFSARMANESH, 2008; PLISSON et al., 2007).

Ao analisar as cadeias de valor de PFNM, Te Velde et al. (2006) também identificam a necessidade de suporte no monitoramento, formação e acompanhamento dessas cadeias e enfatizam a importância dos agentes empreendedores nas cadeias. Para os autores a ação destes agentes pode influenciar o sucesso e até mesmo a existência das cadeias, sendo destacada a necessidade de melhorias no monitoramento das cadeias para diminuir os impactos negativos nas comunidades.

Ao analisar diferentes Projetos Demonstrativos Agroextrativistas (PDAs), Becker e Lená (2003) observam o diferencial da organização em rede da Rede Frutos do Cerrado. Os autores destacam que, mais do que um ganho de escala, a "articulação mediante princípios e diretrizes comuns definidas de forma coletiva" (BECKER; LENÁ, 2003, p. 419) proporcionou melhores resultados comparados aos demais projetos.

Assim, Becker e Lená (2003), Morsello (2006), Ros-Tonen et al. (2008) e Te Velde et al. (2006) apontam para a necessidade de melhoria na relação entre populações tradicionais, mercado, instituições e governo. Porém, há poucas informações sobre casos onde essas relações foram bem intermediadas e os autores trazem poucos direcionamentos quanto aos papéis dos diferentes agentes dentro da cadeia de valor e como essa intermediação e o monitoramento poderiam ocorrer em longo prazo.

Dentro da perspectiva político-econômica nacional, o Governo Federal lançou, em julho de 2009, o Plano Nacional de Promoção das Cadeias dos Produtos da Sociobiodiversidade (PNPSB). O plano contou com coordenação interministerial, envolvendo o Ministério do Desenvolvimento Agrário (MDA), o Ministério do Meio Ambiente (MMA) e o Ministério de Desenvolvimento Social (MDS). O plano buscou fortalecer as cadeias de produtos da sociobiodiversidade por meio de diferentes ações, envolvendo na discussão comunidades, cooperativas, empresas privadas, governos (federal, estadual e municipal), universidades e organizações não governamentais (BRASIL, 2009a, 2009b, 2010). 
Uma das iniciativas do PNPSB foi a formação de Arranjos Produtivos Locais (APLs), com o intuito de promover a melhoria dos PFNM territorialmente ligados às políticas locais, estaduais e federais. Porém, não é claro se a estrutura de um APL é a mais adequada para o setor e restam ainda muitas questões a serem respondidas com relação à realidade dos PFNM e à estruturação dos arranjos produtivos, tais como: de que forma os arranjos podem ser constituídos, como irão considerar as populações tradicionais, como podem evoluir, qual a estrutura de gestão a ser adotada, como os atores locais poderão fazer parte, como se dará a governança do mesmo etc.?

O conceito de aglomeração de um setor produtivo em um território inicia-se com Marshall (1920), que identifica os ganhos com as "economias externas" proporcionadas pela concentração de empresas. Porter (1998) retoma este conceito ao estudar os clusters industriais, argumentando que há um ganho de competitividade por parte das empresas aglomeradas em um território, que dividem competências comuns e complementares.

Além de fatores de proximidade, vantagens competitivas e economias externas, os aglomerados podem ser vistos e entendidos sobre a perspectiva de redes interorganizacionais, redes colaborativas ou redes de cooperação, trazendo um entendimento mais amplo das relações, da coordenação, orientação estratégica, evolução e inovação destas redes (AMATO NETO, 2000; AMATO NETO; FUCCIAMATO, 2009; CAMARINHA-MATOS; AFSARMANESH, 2008; PROVAN; FISH; SYDOW, 2007; PARRILLI; SACCHETTI, 2008).

$\mathrm{Na}$ presente tese foi adotado o termo redes de cooperação ou somente redes para contemplar a organização em rede e as diferentes formas e possibilidades de cooperação interorganizacional dentro de setores econômicos e produtivos.

De maneira geral, para Camarinha-Matos e Afsarmanesh (2008), as redes de cooperação (territoriais, industriais, tecnológicas etc.) podem se constituir como: i) redes espontâneas, sem um processo de gestão estruturado; ii) redes orientadas por objetivos, com formas de organização mais dinâmicas focadas na solução de problemas e aproveitamento de oportunidades de curto prazo; ou, iii) redes de longo 
prazo, buscando ambientes de reprodução e melhoria continua.

Sölvell (2009) e Camarinha-Matos e Afsarmanesh (2008) apontam o ciclo de vida das redes de cooperação. De maneira geral uma rede de cooperação segue os seguintes passos: i) inicio e formação; ii) maturidade e operação; iii) evolução e melhoria contínua; iv) metamorfose, dissolução ou declínio.

Apesar de mais direcionado para o entendimento das relações para redes baseadas/suportadas pela tecnologia da informação, Camarinha-Matos e Afsarmanesh $(2007,2008)$ estudam processos de estruturação de redes de cooperação empresariais. Esta estruturação é complementar às diretrizes já estruturadas para os aglomerados industriais e redes de cooperação estudados por Gerolamo (2007), Carpinetti et al. (2008), Sölvell et al. (2003) e Sölvell (2009). As diretrizes de gestão estruturadas pelas pesquisas em redes de cooperação permitem o entendimento e melhoria dos processos de cooperação para além dos processos espontâneos de organização.

Não foram encontradas na literatura estudos, modelos ou diretrizes que avaliem e orientem a estruturação de redes voltadas às cadeias de PFNM na Amazônia. Com esta perspectiva a presente pesquisa de doutorado buscou preencher a lacuna sobre a estruturação de redes de cooperação e sua influência nas cadeias de valor de PFNM.

Desta maneira, tendo como parâmetro inicial o modo de vida das populações tradicionais, as cadeias de valor de PFNM e os conceitos, princípios e diretrizes da teoria de redes de cooperação, o presente trabalho buscou responder à seguinte questão:

Como as redes de cooperação contribuem para o funcionamento das cadeias de valor de PFNM e de que forma essas redes estão estruturadas?

Visando responder a essas questões foi realizado um estudo de caso da Rede Terra do Meio e das principais cadeias de valor de PFNM da região. 


\subsection{Escopo da Pesquisa}

A pesquisa da tese foi focada nas principais cadeias de valor vinculadas às reservas extrativistas da região da Terra do Meio (castanha, óleos vegetais, copaíba e borracha) e na rede e subrede formada para promover a cooperação interinstitucional no território: a Rede Terra do Meio (RTM) e o Grupo de Trabalho de Atividades Produtivas. Essas áreas fazem parte de um bloco maior de áreas protegidas que constituem o corredor de áreas protegidas da bacia do Xingu (SCHWARTMAN et al., 2013).

A região da Terra do Meio (Figura 1), localizada no estado do Pará, é composta por um grupo de áreas protegidas, tais como: i) Terras Indígenas (TI) - da Cachoeira Seca, Xipaya e Kuruaya; ii) Unidades de Conservação de Proteção Integral - Estação Ecológica (Esec) Terra do Meio e Parque Nacional (Parna) Serra do Pardo; iii) Unidades de Conservação de Uso Sustentável - Reservas Extrativistas (Resex) Rio Xingu, Rio Iriri e Riozinho do Anfrísio; iv) Floresta Estadual (FES) do Iriri; e v) Área de Proteção Ambiental (APA) Triunfo do Xingu. 


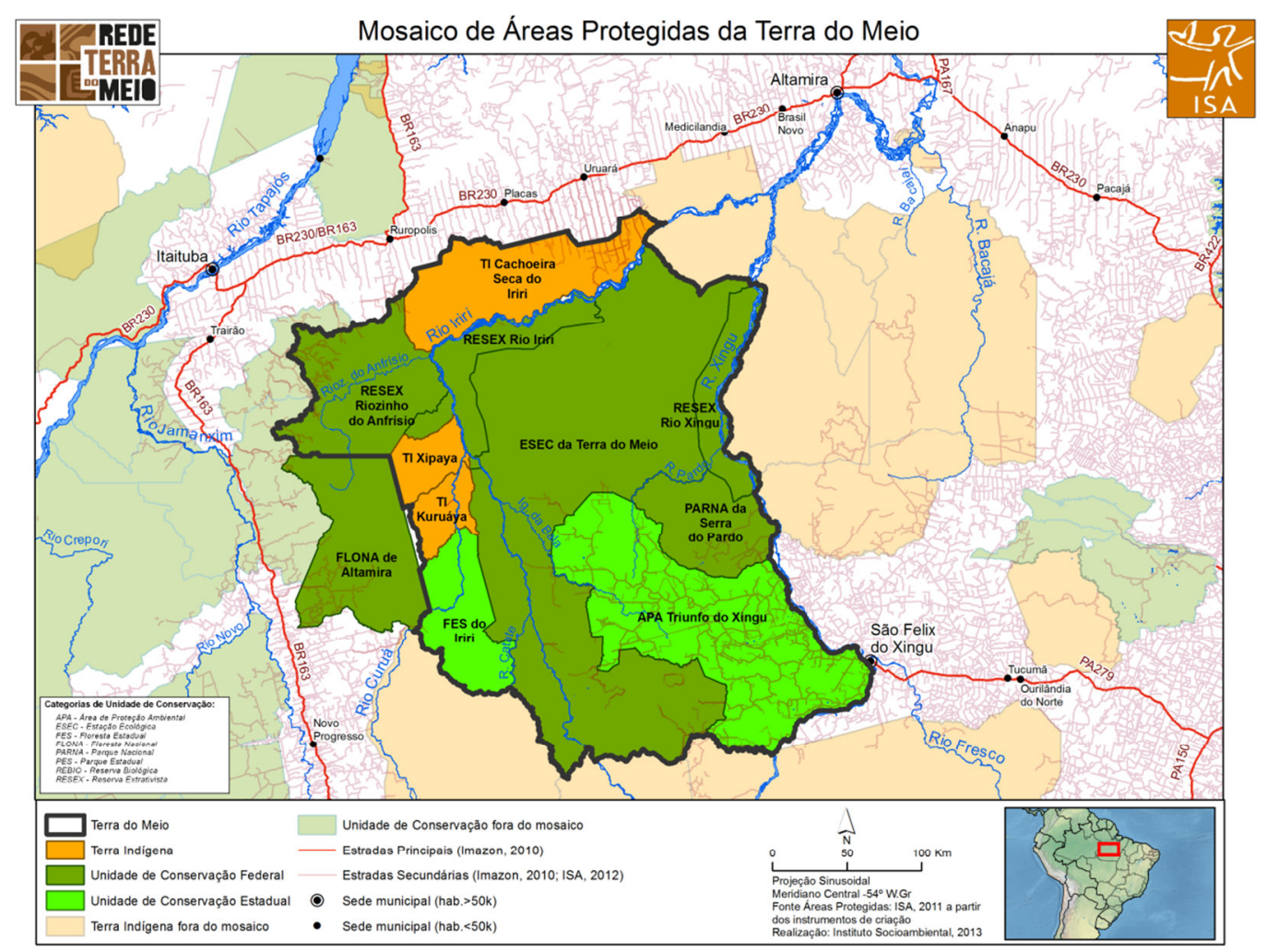

Figura 1: Terra do Meio.

Fonte: REDE TERRA DO MEIO (2013)

A Terra do Meio é constituída por mais de 8,216 milhões de hectares de Terras Indígenas e Unidades de Conservação com florestas e rios ainda bem conservados (VILLAS BOAS, 2012). A região apresenta grande riqueza sociocultural, evidenciada pela presença de sociedades indígenas, povos ribeirinhos e colonos. Em termos quantitativos a população indígena da região de Altamira contempla 12 terras indígenas distribuídas com uma população total de 2.760 pessoas em 27 Aldeias (INSTITUTO SOCIOAMBIENTAL, 2012). Já as três Resex da região da Terra do Meio são habitadas por 184 famílias distribuídas em 68 localidades distribuídas em mais de mil quilômetros de rio (INSTITUTO SOCIOAMBIENTAL, 2012).

O interesse econômico nos recursos naturais regionais (madeira, hidroeletricidade, mineração, etc.), a diversidade de áreas protegidas e etnias existentes e a quantidade de instituições representativas, organizações não governamentais (ONGs) e instituições do governo que atuam na região fazem da Terra do Meio um centro de atenção no âmbito nacional e internacional. Essa diversidade institucional gerou a criação de diferentes fóruns e ambientes de 
encontro para o diálogo sobre o desenvolvimento regional (ALMEIDA, 2004; FEARNSIDE, 2003; ROS-TONEN et al., 2008), com enfoque mais atual em torno das questões socioambientais e econômicas relacionadas à construção da Usina Hidrelétrica de Belo Monte.

A criação das Unidades de Conservação (UCs) da Terra do Meio é resultado de um conjunto de demandas e ações coordenadas entre o Movimento pelo Desenvolvimento da Transamazônica e Xingu (MDTX) e organizações governamentais e não governamentais que visavam, com isso, a diminuição do processo de extração ilegal de madeira, grilagem de terras e desmatamento ocorridos no final da década de 90 e nos primeiros anos de 2000 (CAMPOS; NEPSTAD, 2006; ROS-TONEN et al., 2008; SCHWARTZMANN et al., 2010; VELÁSQUEZ et al., 2006).

Os estudos realizados em 2006 e 2007 pelo Instituto Brasileiro do Meio Ambiente e dos Recursos Naturais Renováveis (Ibama) mostram que até esses anos as Resex eram muito pouco assistidas pelos sistemas públicos de educação e saúde, não existindo escolas ou postos de saúde em nenhuma das Unidades de Conservação da região (INSTITUTO BRASILEIRO DE MEIO AMBIENTE E RECURSOS NATURAIS, 2007a; 2007b). Os estudos mostram também que o índice de analfabetismo nas Resex Riozinho do Anfrísio e Rio Iriri era superior a $80 \%$, sendo que poucos moradores conseguiam assinar seus nomes.

A parceria entre esse conjunto de instituições apoiou processos de denúncias e estudos sobre a região, possibilitando a definição das características e dimensões das Unidades de Conservação possíveis, resultando em um relatório denominado Estudos de Macapá (VELASQUEZ et al., 2006). Com base nesse estudo e com diferentes ações políticas, são criadas as primeiras Unidades de Conservação em 2004, estando o conjunto de Áreas Protegidas da Terra do Meio consolidado em 2008, com a criação da Resex Rio Xingu (SCHWARTZMANN et al., 2010).

Com o inicio do processo de implantação das UCs regionais surge a Rede Terra do Meio - RTM (VELÁSQUEZ et al., 2006). A RTM teve seu início em 2006, caracterizando-se como um fórum de diálogo e um espaço político de governança, 
negociação e planejamento do território entre as principais instituições responsáveis pela criação das Unidades de Conservação na região.

O Grupo de Trabalho (GT) de Atividades Produtivas é uma subrede da RTM, formado por um conjunto de instituições que busca discutir, planejar, coordenar e promover as cadeias de valor de PFNM na região. Esse grupo, que funciona de forma mais estruturada desde 2009, tem o objetivo de atuar com diferentes produtos não madeireiros da região e desenvolver ações de suporte aos primeiros elos da cadeia, envolvendo coletores, ONGs e governo, assim como melhorias e conexões nas cadeias como um todo, principalmente através da estruturação de parcerias entre extrativistas e o mercado (mercado local, mercado institucional e empresas). Estudos realizados pelas instituições participantes desse grupo (COOPERAÇÃO TÉCNICA ALEMÃ, 2009; IBENS, 2009; INSTITUTO BRASILEIRO DE MEIO AMBIENTE E DOS RECURSOS NATURAIS RENOVÁVEIS, 2007a; 2007b; INSTITUTO CHICO MENDES DE CONSERVAÇÃO DA BIODIVERSIDADE, 2010a; 2010b; INSTITUTO DE MANEJO E CERTIFICAÇÃO FLORESTAL E AGRÍCULA, 2011a; 2011b; 2011c) descrevem a importância, os desafios e alguns caminhos para a melhoria das principais cadeias de valor de PFNM regionais, sendo estas: castanha, óleos vegetais, copaíba e borracha.

Assim, a escolha da Terra do Meio e das redes de cooperação atuantes na região como escopo dessa pesquisa ocorreu pela diversidade socioambiental representada por diferentes cadeias, associações e extrativistas; pela realidade de fronteira com pressões de projetos do agronegócio e de desenvolvimento; pela diversidade de instituições atuantes na região; pelo histórico de cooperação interinstitucional para a criação e implantação das UCs da Terra do Meio e pela participação do pesquisador em processos e ações de cooperação para a implementação das UCs na região desde 2006. As características regionais da Terra do Meio ligadas à participação direta do pesquisador nas atividades de cooperação e à facilidade de obtenção de informações e documentos proporcionou um aprofundamento no entendimento dos processos, projetos e relações na rede e nas cadeias de valor de PFNM estudadas. 


\subsection{Objetivo da Pesquisa}

O objetivo da pesquisa foi analisar a contribuição das Redes de Cooperação para estruturação, funcionamento e melhoria das cadeias de valor de PFNM na região da Terra do Meio.

A pesquisa procurou explorar o objetivo proposto através dos seguintes objetivos específicos:

1. Analisar o funcionamento e organização da Rede Terra do Meio e a sua influência nas cadeias de PFNM da Terra do Meio;

2. Analisar a Rede Terra do Meio com base nas teorias de redes de cooperação;

3. Sistematizar diretrizes para a melhoria de redes de cooperação voltadas para cadeias de valor de PFNM.

\subsection{Método de Pesquisa}

A pesquisa apresentou um caráter exploratório, pois buscou levantar e analisar as contribuições, influências e possíveis formas de organização em rede para a promoção das cadeias de PFNM na região da Terra do Meio. Foi feita uma abordagem qualitativa dos dados, seguindo o método de estudo de caso. Os métodos utilizados para a realização da pesquisa foram: análises de documentos, entrevistas em profundidade, observação direta e observação participante.

Análise de documentos: são normalmente utilizados para complementar entrevistas e outros métodos de coleta de dados. Os documentos têm um valor em si mesmo, pois representam sistemas e estruturas da organização. $A$ análise permite o entendimento de situações e permite conceituar a organização com base em uma visão de dentro, em contraste com métodos que se propõem testar hipóteses e partem de uma visão de fora, em que o pesquisador se distancia da realidade 
pesquisada e utiliza instrumentos estruturados em conceitos externos (ROESCH, 1999).

A aquisição dos diferentes documentos vinculados às redes ocorreu pelo acesso direto com as instituições e também pelos seus websites. Foi analisado um total de dezoito documentos, envolvendo documentos de instituições do governo, das instituições participantes da RTM, atas de reuniões, relatórios e documentos relativos a estudos, planejamentos e ações nas cadeias de valor de PFNM na região.

Entrevistas em profundidade: visa captar 0 entendimento que os entrevistados possuem sobre o objeto da pesquisa. Dessa forma "o pesquisador não está predeterminando sua perspectiva por meio de uma seleção prévia de categorias de questões, como no caso de quem utiliza um método quantitativo" (Roesch, 1999, p. 159). Isso viabiliza que o entrevistador capte e entenda a perspectiva do entrevistado da pesquisa.

Foram realizadas doze entrevistas ao longo da pesquisa. As entrevistas foram realizadas de forma semi-estruturadas, ou seja, o pesquisador determina os tópicos a serem utilizados e guia a entrevista dentro destes tópicos, porém sem perguntas fechadas e sem uma sequencia rígida e não estruturadas. Isso permitiui que 0 assunto fosse tratado de maneira mais livre, favorecendo a obtenção de dados e informações não projetadas. Foram entrevistadas cinco empresas, cinco instituições locais, e dois comunitários.

Observação direta e participante: a observação direta possibilita ao pesquisador observar as práticas de gestão adotadas pelas diferentes unidades de análise. A observação direta e participante ocorreu através do acompanhamento e organização de: i) reuniões e treinamentos; ii) processos de planejamento interinstitucionais; iii) processos operacionais e de melhoria.

A participação do pesquisador foi variável ao longo da pesquisa, com papel de observador em algumas reuniões, sem atuação direta sobre o tema abordado, e com papel de especialista e moderador em outras, influenciando diretamente 
processos de treinamento, reuniões da RTM e do GT de atividades produtivas, processos de planejamento e melhoria das cadeias de valor. Assim, a pesquisa foi realizada em vinte e duas reuniões interinstitucionais, dez reuniões comunitárias, três visitas à empresas e duas reuniões comunidades-empresas-instituições.

O Quadro 1 apresenta os pontos fortes e fracos dos diferentes métodos de coleta de dados utilizados na pesquisa. Yin (2005) recomenda a utilização de diferentes fontes, viabilizando a posterior triangulação e comparação das informações, favorecendo a análise das convergências e divergências das evidências.

Observa-se, com base nos pontos fortes e fracos abordados por Yin (2005), que há uma complementaridade dos métodos escolhidos para a pesquisa. Além da simples observação, entrevistas e levantamento de documentos, o pesquisador adotou uma estratégia propositiva e participante sobre a realidade observada, o que demandou do pesquisador um elevado tempo de campo e favoreceu o aprofundamento no contexto local e suas modificações.

A pesquisa foi realizada ao longo dos quatro anos de doutorado, entre $2010 \mathrm{e}$ 2014, com a participação direta do pesquisador em reuniões e atividades das cadeias de valor e na realização de entrevistas com atores-chave das cadeias. $O$ histórico de atuação do pesquisador na região desde 2006 garantiu a confiança e disponibilidade das instituições, comunidades e empresas para a aquisição de informações importantes para o entendimento da dinâmica regional. $O$ detalhamento das atividades e métodos utilizados ao longo dos quatro anos de pesquisa de campo é apresentado no APÊNDICE A.

Foram realizadas atividades de pesquisa nos diferentes espaços de governança do território e das cadeias de valor, tendo como unidades de análise gerais: a Rede Terra do Meio, o Grupo de Trabalho de Atividades Produtivas da Rede Terra do Meio e as Cadeias de Valor de PFNM das Resex da Terra do Meio. E como unidades de análise específicas: os extrativistas, os representantes institucionais e representantes do mercado. 
Quadro 1: Fontes de evidências - pontos fortes e pontos fracos.

\begin{tabular}{|c|c|c|}
\hline $\begin{array}{l}\text { Fontes de } \\
\text { evidências }\end{array}$ & Pontos Fortes & Pontos Fracos \\
\hline Documentação & $\begin{array}{l}\text { - Estável - pode ser revisada } \\
\text { inúmeras vezes } \\
\text { - Discreta - não foi criada como } \\
\text { resultado do estudo de caso } \\
\text { - Exata - contém nomes, } \\
\text { referências e detalhes exatos de } \\
\text { um evento } \\
\text { - Ampla cobertura - longo espaço } \\
\text { de tempo, muitos eventos e } \\
\text { muitos ambientes distintos }\end{array}$ & $\begin{array}{l}\text { - Capacidade de recuperação - } \\
\text { pode ser baixa } \\
\text { - Seletividade tendenciosa, se } \\
\text { a coleta não estiver completa } \\
\text { - Relato de vieses - reflete as } \\
\text { idéias preconcebidas } \\
\text { (desconhecidas) do autor } \\
\text { - Acesso - pode ser } \\
\text { deliberadamente negado }\end{array}$ \\
\hline Entrevistas & $\begin{array}{l}\text { Direcionadas - enfocam } \\
\text { diretamente o tópico do estudo } \\
\text { de caso } \\
\text { - Perceptivas - fornecem } \\
\text { inferências causais percebidas }\end{array}$ & $\begin{array}{l}\text { - } \text { Vieses devido a questões mal } \\
\text { - } \quad \text { Resporadas } \\
\text { - Ocorrem imprecisões devido } \\
\text { à memória fraca do } \\
\text { entrevistado } \\
\text { - } \text { Reflexibilidade - o } \\
\text { entrevistado da ao } \\
\text { entrevistador aquilo que ele } \\
\text { quer ouvir }\end{array}$ \\
\hline Observação direta & $\begin{array}{l}\text { - Realidade - tratam de } \\
\text { acontecimentos em temo real } \\
\text { - Contextuais - tratam do } \\
\text { contexto do evento }\end{array}$ & $\begin{array}{l}\text { - } \text { Consomem muito tempo } \\
\text { - } \text { Seletividade - salvo ampla } \\
\text { - Reflexibilidade - o } \\
\text { acontecimento pode ocorrer } \\
\text { de forma diferenciada porque } \\
\text { está sendo observado } \\
\text { - Custo - horas necessárias } \\
\text { pelos observadores humanos }\end{array}$ \\
\hline $\begin{array}{l}\text { Observação } \\
\text { participante }\end{array}$ & $\begin{array}{l}\text { - } \text { os mesmos mencionados para } \\
\text { observação direta] } \\
\text { - Perceptiva em relação a } \\
\text { comportamentos e razões } \\
\text { interpessoais }\end{array}$ & $\begin{array}{l}\text { - } \quad \text { os mesmos mencionados } \\
\text { - Viese observação direta] } \\
\text { dos eventos por parte do } \\
\text { pesquisador }\end{array}$ \\
\hline
\end{tabular}

Fonte: adaptado de Yin (2005, p. 113)

Para a estruturação do estudo de caso foi seguido, basicamente, o método proposto por Yin (2005). O método começa com um desenvolvimento de teoria, com base na literatura existente, seguindo para a seleção dos casos e o desenvolvimento do protocolo e questionário de pesquisa, conforme apresentado na Figura 2 e descrito na sequência. 


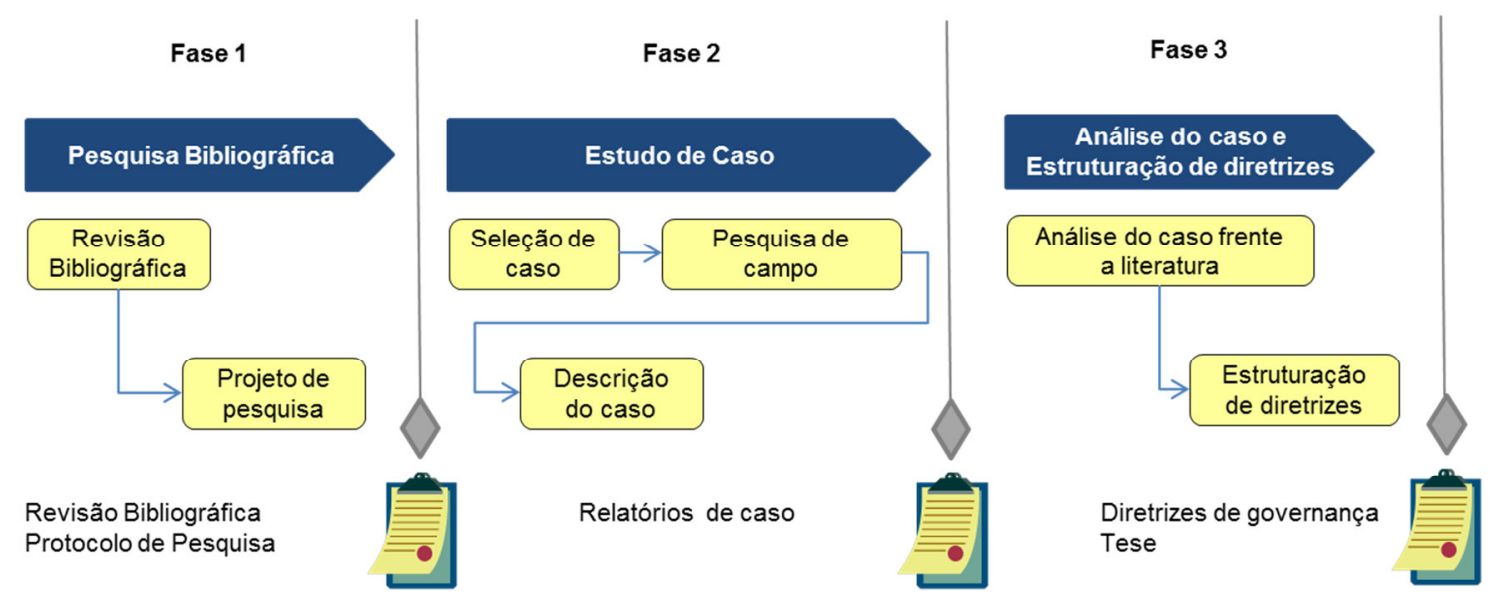

Figura 2: Fases da Pesquisa.

Fase 1- Pesquisa Bibliográfica: Levantamento, leitura e sistematização da literatura, considerando principalmente: redes de cooperação, cadeias de valor de PFNM, relação empresa-comunidade, empreendimentos comunitários e diretrizes de gestão de redes. A partir do referencial teórico existente e dos objetivos da pesquisa foi estruturado o protocolo de pesquisa (Quadro 2).

Fase 2-Estudo de Caso: Foi realizado o estudo de caso da Rede Terra do Meio, do GT de Atividades Produtivas e das diferentes cadeias de valor trabalhadas pelas Resex em cooperação com as instituições participantes da rede. Foram estruturados relatórios para os diferentes processos da rede e para as cadeias de valor, contendo a descrição dos casos e entendimento dos processos de gestão e formas de organização. Os relatórios descritivos dos diferentes processos e cadeias foram cruzados de forma a encontrar pontos comuns e complementares, buscando o entendimento das dinâmicas de funcionamento da rede e as possíveis influências nas cadeias de valor.

Fase 3- Sistematização da estrutura de governança: A partir dos estudos sobre as cadeias de valor de PFNM, das estruturas de redes de cooperação levantadas pela literatura e do resultado da análise do caso foi feita a sistematização de uma estrutura de apoio à governança de redes voltadas às cadeias de PFNM.

O protocolo de pesquisa utilizado, onde estão sintetizadas as informações centrais de coleta e análise de dados, é apresentado no Quadro 2. 
Quadro 2: Protocolo de pesquisa

\begin{tabular}{|c|c|}
\hline \multicolumn{2}{|r|}{ Protocolo de pesquisa } \\
\hline Questão de Pesquisa & $\begin{array}{l}\text { Como as redes de cooperação contribuem para o funcionamento } \\
\text { das cadeias de valor de PFNM e de que forma essas redes estão } \\
\text { estruturadas? }\end{array}$ \\
\hline Unidades de Análise & $\begin{array}{l}\text { Nível } 1 \text { - Unidades de análise gerais: } \\
\text { - Rede Terra do Meio; } \\
\text { - Grupo de Trabalho de Atividades Produtivas; } \\
\text { - Cadeias de Valor de PFNM das Resex da Terra do Meio; } \\
\text { Nível } 2 \text { - Unidades de análise de caso: } \\
\text { - Extrativistas - Representantes das comunidades e } \\
\text { - gestores de "empreendimentos" comunitários; } \\
\text { - } \text { - } \text { - Mede - Instituições de apoio e núcleo de gestão da RTM e } \\
\text { - Mercado- Empresas e comerciantes locais; }\end{array}$ \\
\hline $\begin{array}{l}\text { Período da pesquisa } \\
\text { de campo }\end{array}$ & $\begin{array}{l}\text { Períodos alternados entre Agosto de } 2010 \text { e Junho de } 2014 \text {, } \\
\text { conforme coronograma no Apêndice A. }\end{array}$ \\
\hline Local & Terra do Meio, Altamira, Pará. \\
\hline $\begin{array}{l}\text { Validade dos } \\
\text { Construtos }\end{array}$ & $\begin{array}{l}\text { Utilização de dados coletados por observação direta, observação } \\
\text { participante nas cadeias e projetos locais (cadernos de campo), } \\
\text { análise de documentos e entrevistas em profundidade com } \\
\text { representantes comunitários, das instituições de apoio e } \\
\text { empresas. }\end{array}$ \\
\hline $\begin{array}{l}\text { Questões centrais } \\
\text { dos estudos de caso }\end{array}$ & $\begin{array}{l}\text { - } \text { Qual é o histórico e como ocorreu a evolução da Rede } \\
\text { Terra do Meio, do GT de Atividades Produtivas e das } \\
\text { cadeias de valor de PFNM? } \\
\text { - Como a RTM, o GT de Atividades Produtivas e as cadeias } \\
\text { de valor de PNFM funcionam e estão organizadas? } \\
\text { - Como as redes de cooperação influenciam as cadeias de } \\
\text { PFNM na Terra do Meio? } \\
\text { - Quais processos apoiam o entendimento e melhoria de } \\
\text { redes e cadeias de valor de PFNM na Terra do Meio? }\end{array}$ \\
\hline $\begin{array}{l}\text { Estratégia de Análise } \\
\text { de dados }\end{array}$ & - Análise a partir de descrição de caso. \\
\hline Técnicas Analíticas & $\begin{array}{l}\text { - Descrição de caso - descrição do caso, contemplando as } \\
\text { questões centrais de pesquisa; } \\
\text { - Modelos lógicos - Mapa de fluxo de valor das cadeias de } \\
\text { PFNM (STRAATMANN; GEROLAMO; CARPINETTI, } \\
\text { 2011). }\end{array}$ \\
\hline
\end{tabular}




\section{Revisão Bibliográfica}

O referencial teórico pesquisado busca trazer o entendimento sobre a relação entre as populações tradicionais, os PFNM, a perspectiva histórica destes produtos, populações e sistema de governança, o entendimento de redes de cooperação e a relação entre os PFNM e as redes de cooperação.

\subsection{Produtos Florestais Não Madeireiros e Populações Tradicionais}

Os PFNM são, em geral, de origem extrativista de áreas florestais, trabalhados por populações residentes no entorno ou dentro das florestas. Alguns PFNM encontrados na Amazônia são: a castanha do Pará, o látex, o açaí, óleos e manteigas de sementes (andiroba, babaçu, patauá, buriti, pracaxi, maracujá, bacuri, cupuaçu, muru-muru, ucuúba, etc.), resina de copaíba, cumaru, cacau e outras frutas, sementes, raízes, folhas e cascas de uso tradicional e que abastecem os mercados alimentícios, farmacêuticos, cosméticos etc.

Segundo os levantamentos do Instituto Brasileiro de Geografia e Estatística (IBGE) no segmento do extrativismo vegetal, a produção madeireira totalizou $R \$ 3,3$ bilhões, enquanto que a extração vegetal não madeireira somou $R \$ 983,3$ milhões (INSTITUTO BRASILEIRO DE GEOGRAFIA E ESTATÍSTICA, 2012). O Instituto Brasileiro de Geografia e Estatística (2012) aponta seis produtos como responsáveis por $90,6 \%$ do valor total da produção de PFNM, sendo eles: coquilhos de açaí (R\$ 336,2 milhões), erva-mate nativa ( $R$ \$ 155,3 milhões), amêndoas de babaçu ( $R$ \$ 127,6 milhões), fibras de piaçava ( $R \$ 109,0$ milhões), pó de carnaúba ( $R \$ 95,1$ milhões) e castanha-do-pará ( $R \$ 68,4$ milhões).

Apesar da baixa representatividade em termos de valor na economia nacional, os PFNM são uma das principais fontes de renda para as Populações Tradicionais e Indígenas da região Amazônica. As Populações Tradicionais são definidas pelo 
decreto $N^{\circ} 6.040$, Art. $3^{\circ}$, inciso I, do Governo Federal como:

Grupos culturalmente diferenciados e que se reconhecem como tais, que possuem formas próprias de organização social, que ocupam e usam territórios e recursos naturais como condição para sua reprodução cultural, social, religiosa, ancestral e econômica, utilizando conhecimentos, inovações e práticas gerados e transmitidos pela tradição (BRASIL, 2007).

O acesso a terra é um dos principais motivadores de luta dessas populações, sendo condição necessária para a reprodução de sua cultura, modo de vida, produção, sobrevivência e acesso a direitos. As questões fundiárias trazem vulnerabilidade para as comunidades, as quais ficam expostas a grilagem de terra e invasões, e sofrem pela falta de acesso ao crédito rural e a políticas públicas (SALISBURRY; SCHMINK, 2007; WALKER et al., 2009).

Especialmente na década de 1980 e 1990, com o aumento da luta pela criação de áreas protegidas que garantissem o acesso a terra das populações tradicionais, a produção e comercialização de PFNM foi considerada uma solução provável para a redução da pobreza conciliada à conservação ambiental das florestas (FALCONER, 1999; NEPSTAD; SCHWARTZMAN, 1992). Os PFNM são uma fonte de renda importante para as populações tradicionais, as quais historicamente utilizam a floresta com baixo impacto ambiental, contribuindo para sua conservação, especialmente em comparação a formas mais predatórias de uso da terra, como a pecuária (SALISBURY; SCHMINK, 2007). No entanto, a comercialização desses produtos, como ação isolada, é insuficiente para a redução da pobreza e se feita de forma desestruturada pode gerar pressão sobre os recursos naturais e as comunidades (BELCHER; RUÍZ-PÉRES; ACHDIAWAN, 2005; MORSELLO, 2006; NKEM et al., 2010; MORSELLO et al., 2012).

A extração de PFNM é realizada, normalmente, com baixa agregação de valor, com práticas de qualidade que atendem às cadeias historicamente instituídas na região, com forte presença de atravessadores, falta de crédito e baixo acesso ao mercado (BELCHER; RUÍZ-PÉRES; ACHDIAWAN, 2005; NKEM et al., 2010). Essas relações são mais bem compreendidas pelo entendimento do histórico das cadeias de valor, da organização extrativista e das relações com o mercado apresentados 
nos itens a seguir.

\subsubsection{Histórico das Cadeias de Valor de PFNM}

As cadeias de PFNM estruturam-se e se conectam ao mercado desde a colonização, com a extração e comercialização das especiarias ou drogas do sertão (RIBEIRO D., 1995; DE SARTRE; TARAVELLA, 2009). No século XIX, com o primeiro ciclo da borracha, a exploração do látex se intensifica fortalecendo a economia do Norte do país e expandindo uma rede de extrativistas (seringueiros), patrões (seringalistas) e comerciantes (RIBEIRO D., 1995, ANDRADE, MATTOS; ARAÚJO, 2008). Essa rede se forma com a exploração da mão de obra existente localmente e com a migração de nordestinos em diferentes épocas do século XIX e XX (GIRÃO, 1985).

Com o fim do primeiro ciclo da borracha, em 1913, ocorrido pela transição do extrativismo na Amazônia para o plantio das seringueiras na Ásia, e decorrente queda nos preços, houve uma falência dessa rede de fornecimento amazônico, com 0 "abandono" dos seringais pelos seringalistas e por parte da população (ALEGRETTI, 2002; ANDRADE; MATTOS; ARAÚJO, 2008). Esse processo liberou a população do sistema de patronagem e permitiu que os mesmos ampliassem seus conhecimentos e práticas sobre a floresta, agricultura, pesca e caça, levando à estruturação de uma população especializada nas dinâmicas florestais (ALMEIDA, 2004).

O segundo ciclo da borracha, durante a segunda guerra mundial, trouxe um novo processo de migração de nordestinos para os rios amazônicos, sendo que esses imigrantes ficaram conhecidos como "soldados da borracha" (GIRÃO, 1985; ALMEIDA, 2004; DE SARTRE; TARAVELLA, 2009; ANDRADE; MATTOS; ARAÚJO, 2008). Segundo Almeida (2004), o segundo ciclo da borracha não obteve os resultados esperados pelo Brasil e Estados Unidos da América, especialmente pela absorção dos "soldados da borracha" na dinâmica do campesinato florestal. Esses se tornam parte da dinâmica de vida da floresta, conquistando com isso maior 
autonomia sobre o uso dos recursos naturais e maior possibilidade de escolha de atividade. Com o fim da guerra houve um novo "abandono" dos seringais e a fixação dessa população na floresta.

Com a ditadura militar há um novo momento econômico e migratório para a região amazônica com o lema de "integrar para não entregar" (SOUZA, 2006; SALISBURY; SCHMINK, 2007; DE SARTRE; TARAVELLA, 2009). Neste momento o governo incentiva a colonização da região e abre estradas (transamazônica - BR 230, Cuiabá-Santarém - BR 163 etc.), motivando o desmatamento, plantio de espécies exóticas e criações (SOUZA, 2006). Esse processo aumenta a pressão na região com relação às terras, madeira, garimpo e criação de gado (FEARNSIDE, 2003).

Com o projeto de integração nacional surgem cidades, megaprojetos de "desenvolvimento", colônias e fazendas, que aumentam a pressão sobre as populações tradicionais e os recursos naturais. Torna-se constante a violência contra essas populações, migrações forçadas e a utilização de sua força de trabalho nessa nova dinâmica socioeconômica (ANDRADE; MATTOS; ARAÚJO, 2008, FEARNSIDE, 2003).

A visão de desenvolvimento para a região amazônica passa a não mais ser baseada na economia extrativista preponderante até então. A nova visão tem uma dinâmica de grande exploração dos recursos naturais (madeira, ouro, ferro, alumínio), de produção de gêneros alimentícios, gado, monocultura em latifúndios e alguma industrialização (DE SARTRE; TARAVELLA, 2009). Dessa forma, as cidades e a população de maneira geral se voltam para as rodovias, fazendas, madeireiras, mineradoras e projetos industriais, dando menos importância para os rios, as florestas e suas populações.

Esse processo de abandono e a pressão sobre os recursos naturais e populações tradicionais geram o aumento da mobilização e surgimento de formas de representação política em diferentes regiões da Amazônia brasileira, sendo alguns: - Conselho Nacional dos Seringueiros (CNS) no Acre (ALLEGRETTI, 2002; ALMEIDA, 2004; ANDRADE; MATTOS; ARAÚJO, 2008); o Movimento de Defesa da 
Transamazônica e Xingu (MDTX) na região da Transamazônica no Pará (SOUZA, 2006; ROS-TONEN et al., 2008); as Comissões Pastorais da Terra (CPT) e movimentos eclesiásticos (SOUZA, 2006; BECKER e LENA, 2003); e, os movimentos Indígenas e Indigenistas em todo o Brasil (FEARNSIDE, 2003). Esses diferentes movimentos buscam o acesso a direitos básicos para as diferentes populações residentes na Amazônia, tais como: direito a terra, acesso à educação, saúde, transporte e a melhoria nas cadeias produtivas dos diferentes produtos agroextrativistas.

Os movimentos sociais ganham força e apoio internacional com a realização da RIO 92, segundo Fearnside (2003). Para esse autor, após a conferência cresce a atenção nacional e internacional para a Amazônia, com aumento na criação de áreas protegidas e fortalecimento da ação de organizações governamentais, não governamentais e de cooperação técnica internacional na região. Nesse processo há, também, maior atenção sobre as cadeias de valor dos PFNM, especialmente através dos Projetos Demonstrativos Agroextrativistas (PDA), financiados pelo PPG7 (Programa Piloto para a Proteção das Florestas Tropicais do Brasil) (FEARNSIDE, 2003; BECKER; LENÁ, 2003).

De Sartre e Taravella (2009) analisam esse momento histórico entre a transição de um projeto desenvolvimentista militar para um projeto socioambiental e de conservação da floresta. Segundo os autores esse conflito de perspectivas se potencializa com a narrativa de internacionalização da Amazônia e de busca por soberania nacional, argumentos oriundos dos militares e fortalecidos com o aumento da presença de organizações e recursos internacionais para a conservação ambiental.

Os movimentos da década de 80 e 90 fizeram com que na região amazônica e seu entorno se instituísse um sistema de governança forte, interligado e complexo. Esse sistema ganhou influência nos processos de desenvolvimento regional, podendo tanto apoiar quanto inibir ações nas cadeias dos diferentes produtos regionais. Assim, destaca-se a importância de entendimento, análise e mobilização deste capital social regional para a promoção das cadeias e redes de PFNM. 


\subsubsection{A Organização Extrativista}

Para se pensar em formas de organização que contemplem os produtos extrativistas é necessário entender a dinâmica de funcionamento das populações que trabalham e dependem historicamente desses produtos. Esse entendimento é importante para a análise das formas de intervenção das empresas, ONGs, governo e movimentos sociais nas comunidades e cadeias de valor. Não se pretende, porém, esgotar a literatura sociológica e antropológica sobre essas populações e suas relações com a floresta, e sim trazer uma visão geral sobre seu modo de vida, em especial do "Campesinato Florestal" (ALMEIDA, 2004; GUERRERO; FURIER; TORRES, 2009, p. 6).

Partindo do decreto das Populações Tradicionais (BRASIL, 2007), observa-se que as relações dessas populações com o território e a dinâmica de funcionamento do mesmo é ponto fundamental para entender a própria dinâmica do extrativismo. Como estratégia de sobrevivência essas populações aprenderam a lidar com a dinâmica da floresta, sua sazonalidade, seus alimentos, remédios, chuvas e secas. Houve, assim, a combinação entre culturas, crenças, ensino/aprendizagem e conhecimento com as dinâmicas florestais.

Para facilitar o entendimento, sintetizar as observações da literatura consultada e trazer um olhar mais objetivo, optou-se pela definição de algumas estratégias adotadas como parte do modo de vida das populações tradicionais. Essas estratégias trazem aspectos observados como importantes para a sobrevivência e reprodução cultural e familiar nos ambientes florestais. Assim, destaca-se:

- Trabalho com diferentes produtos ao longo do ano: é comum nas populações tradicionais e campesinas o aprendizado com o manejo de diferentes produtos, que são utilizados em seu processo de reprodução e sobrevivência familiar, ocorrendo comercialização do excedente (GUERRERO; FURIER; TORRES, 2009; TORRES, 2008; WOORTMANN, 2001). De seus territórios essas populações extraem e beneficiam quase 
todos os recursos necessários para a sua sobrevivência, tais como: remédios, canoas, remos, material de construção, impermeabilizantes, frutas, sementes, caça, pesca etc. Além do extrativismo, a agricultura de subsistência possui uma dinâmica própria e o envolvimento de toda a família no trabalho, sendo que "o consórcio da agricultura com o extrativismo garante 'segurança alimentar' ao grupo" (GUERRERO; FURIER; TORRES, 2009, p. 11). A visão dos diferentes produtos ao longo dos meses do ano permite enxergar um "calendário produtivo", que demonstra a complementaridade entre os produtos trabalhados e uma forma de planejamento e divisão tácita do trabalho.

- Planejamento tácito do trabalho e família: o planejamento do trabalho é baseado no suporte do sustento da unidade familiar e na produção de um excedente para comercialização ou troca por produtos industrializados, segundo Woortmann (2001). Para esse autor, esses produtos possuem valores de uso e não necessariamente valor de mercado, ou seja, é comercializado o que é excedente da produção familiar, ocorrendo a "troca" por produtos que não conseguem produzir. O resultado da produção é de toda a família e não dos indivíduos separados. Assim, não há no campesinato uma lógica de acumulação de bens e sim uma lógica de satisfação das necessidades da família.

Woortmann (2001) destaca que a estratégia de produção é determinada e parcialmente limitada pela necessidade de consumo da família e não necessariamente pela capacidade de produção da mesma. Porém, essa estratégia pode ser estimulada pelas relações com 0 "sistema maior" em que se insere (comunidade, parentes, vizinhos, comerciantes, etc.). Mas, mesmo nesse sistema, o núcleo de produção doméstico ainda conta com autonomia e relações próprias de reciprocidade, como um "estado da natureza" ou mesmo uma instituição anárquica dentro do sistema. Assim, 
níveis de intensidade acima de suas necessidades, isto se deve ao fato de que elas contribuem para o sistema maior com trabalho doméstico excedente, o que parece ser acentuado em sociedades com chefia do tipo "big man". (WOORTMANN, 2001, p. 16).

- Relações específicas de troca e reciprocidade: as relações existentes entre as famílias ou núcleos de produção doméstica são marcadas por relações de compadrio, vizinhança e interdependência fortes e variadas de acordo com as regiões e grupos étnicos. Através dessas relações ocorrem trocas de: i) força de trabalho, as quais contribuem para a execução de atividades gargalos familiares ou comunitários, como a abertura de roças e construção de casas e infraestruturas; ii) excedentes produtivos, extrativistas ou de caça, que evitam desperdício de recursos e apoio mútuo; e mesmo, iii) filhos e afilhados que podem contribuir com a sobrevivência familiar, sem ferir nenhum padrão de ética local (WOORTMANN, 2001). Assim, Woortmann (2001) destaca que,

Como em outras partes do Brasil, as relações de parentesco (e de compadrio) traziam consigo formas de ajuda mútua nas etapas mais "pesadas" do processo produtivo, o que reduzia a intensidade de trabalho dos membros de cada grupo doméstico. A família que recebia a ajuda num momento prestava ajuda em outro momento, seguindo um padrão de reciprocidade. A área cultivada por cada grupo doméstico podia, então, ser maior do que seria se contasse apenas com sua própria mão de obra (WOORTMANN, 2001, p. 10).

- Economia interna e economia externa: historicamente essas comunidades instituíram relações com a economia capitalista. Essa relação se inicia para os povos indígenas com a chegada dos portugueses e as trocas com os mesmos por produtos industrializados (RIBEIRO D., 1995). Com os ciclos da borracha as populações tradicionais ampliam os contatos com o capital, ocorrendo migrações maciças de emigrantes para os seringais, os quais utilizam bens industrializados para o seu modo de vida, que se estrutura mais como um modelo campesino após o fim dos ciclos da borracha (ALMEIDA, 2004; GUERRERO; FURIER; TORRES, 2009). 
Stoian (2005) destaca a importante relação dos extrativistas com as cidades. Há uma dependência dessas populações com as cidades, seus serviços e com os trabalhos temporários. Esses trabalhos esporádicos são fundamentais na complementação da renda campesina e das populações tradicionais, na aquisição de serviços (saúde, educação, aposentadoria, etc.) e bens industrializados.

Além das relações com o mercado e cidades, as populações tradicionais trabalham em paralelo as relações não capitalistas, de produção, troca e reciprocidade, que marcam a existência de uma economia interna (POSTIGO, 2010; GUERRERO; FURIER; TORRES, 2009, p. 7). Essa economia se fortalece através do beneficiamento, para uso e consumo, das matérias-primas extraídas ou produzidas, pela troca de produtos in natura ou processados e serviços (dias de trabalho, realização de parto, tratamento de doenças, etc.) como apresentado nos itens anteriores.

Postigo (2010), ao estudar as populações tradicionais da Resex Alto Juruá, identifica as diferentes formas de relações em rede das famílias, assim como a relação dessas famílias com a mata, sendo que:

[...] a atividade de caça entre os seringueiros do Alto Juruá está relacionada a redes intensas e obrigatórias de reciprocidade de carne de caça, assim como a um conjunto de regulamentos das relações estabelecidas entre aquele que fornece ou libera a carne de caça no seio da mata, o dono da mata ou Caipora, aqueles que recebem a caça, o caçador, e aqueles que vizinham carne de caça entre si, os vizinhos. (IBID, p. 284).

As informações organizadas nesse capítulo buscaram apresentar de forma sintetizada algumas relações do modo de vida das populações com o território. Esse entendimento é importante para relacionar minimamente alguns aspectos do extrativismo com a sociedade e o mercado de forma geral. A relação das populações e suas estratégias com o mercado e redes de PFNM são apresentadas a seguir. 


\subsection{Relações com o Mercado}

A literatura consultada sobre os PFNM traz um enfoque mais direcionado para as parcerias comerciais e cadeias de valor. Poucos estudos foram encontrados sobre redes para PFNM, sendo buscados, também, trabalhos que tratam de redes e produtos rurais de pequenos produtores, campesinos, associações e cooperativas rurais. Esses podem trazer contribuições para este trabalho, apesar de não serem referentes diretamente ao tema de pesquisa.

Homma (1992), ao analisar a produção extrativista e sua relação com o mercado capitalista, descreve um ciclo para o extrativismo vegetal. O autor aponta um ciclo lógico entre a demanda do mercado e a disponibilidade, sendo que o valor e a demanda tendem a crescer até atingir um ponto auge do extrativismo. Nesse ponto a demanda pelo produto continua grande, com um bom preço, mas não se consegue ampliar o fornecimento do produto (tanto pela quantidade limitada do mesmo ou pela quantidade de mão de obra necessária). Com o aumento da demanda pode ocorrer uma super exploração e redução da disponibilidade natural da espécie, ocorrendo uma tendência natural do mercado por procurar a domesticação e monocultura do produto ou mesmo a substituição por produtos sintéticos. Isso levaria ao fim da economia extrativista, sendo exemplos desse processo a borracha (domesticação e monocultura na Ásia e borracha sintética), o guaraná (domesticação e monocultura) e o cacau (domesticação e monocultura).

Porém, há produtos que são obtidos somente via extrativismo, que são difíceis de domesticação ou privatização para cultivo e podem ser manejados de forma apropriada, o que traz a continuidade desses processos (VACCARO; ZANOTTI; SEPEZ, 2009). Além dos produtos, existem diferentes territórios voltados para a conservação ambiental e para a reprodução do modo de vida das populações tradicionais.

Segundo Marshall, Newton e Schreckenberg (2003), além de ser importante para a economia local, a comercialização dos PFNM pode gerar impactos positivos 
na governança territorial e na manutenção do modo de vida das comunidades.

A literatura consultada foi dividida por algumas perspectivas de estudo e intervenção nas cadeias de valor, sendo categorizadas relações com o mercado através: i) da relação direta comunidade-empresa ou mediadas por uma instituição intermediária governamental ou não governamental; ii) das relações já instituídas nas cadeias de valor; iii) da relação em rede para lidar com a governança florestal e as cadeias de valor de forma mais abrangente.

\subsubsection{Relações empresas e comunidades}

Segundo Ros-Tonen et al. (2008) diferentes fatores mundiais e nacionais levam a uma nova tendência de formação de parcerias para a governança florestal e a relação de produção e comercialização entre empresa e comunidade:

No âmbito global:

i) as mudanças quanto ao pensamento sobre governança; ii) as reformas políticas neoliberais e o declínio do Estado; iii) a globalização e a melhora relativa nas comunicações transnacionais; e iv) a aceitação geral das normas de manejo sustentável de florestas (ROS-TONEN et al., 2008, p.1483).

No âmbito nacional:

i) políticas e descentralização; ii) devolução de direitos de propriedade a indígenas e outras comunidades locais; e iii) a onda de democratização dos anos 80 que resultou no desenvolvimento de sociedade civil forte (ROS-TONEN et al., 2008, p. 1483).

Para Morsello (2006) as mudanças ocorridas na governança das florestas, especialmente do controle do Estado para o controle das comunidades têm levado as empresas a adotarem novas estratégias para responder às demandas de uma complexa organização de stakeholders e de produtos com apelo socioambiental. É 
apontado que as parcerias comunidade-empresa podem ser um caminho a ser seguido, apresentando melhores resultados do que nenhuma parceria. Porém, o excesso de controle e intervenção por parte das empresas pode gerar um maior conflito e mudanças nas formas tradicionais de relação social e ambiental (MORSELLO, 2006, ROS-TONEN et al. 2008; LE TOURNEAU; GREISSING, 2010).

Morsello (2006), Ros-Tonen et al. (2008), Le Tourneau e Greissing (2010) apontam algumas vantagens possíveis com a instituição de parcerias entre comunidades e empresas, sendo elas:

- Estratégia de marketing, relacionando a empresa a uma boa imagem socioambiental e de biodiversidade;

- Possibilidade de gerar maior retorno financeiro para as comunidades quando comparado ao mercado local;

- Possibilidade de garantia de mercado para alguns produtos;

- Possibilidade de investimentos e melhoria de infraestrutura para o beneficiamento dos PFNM;

Segundo Le Tourneau e Greissing (2010), as relações de parceria são muito novas, em alguns casos inovadoras, e por isso há um "trade-off” ou mesmo perdas inevitáveis para as comunidades. Algumas perdas ou desconexões nas parcerias comunidade-empresa são levantadas com base nas experiências entre a Body Shop e os Kayapós (MORSELLO, 2006; ROS-TONEN et al., 2008) e a Natura e a Reserva de Desenvolvimento Sustentável (RDS) do Iratapuru (LE TOURNEAU; GREISSING, 2010), podendo-se citar:

- Grande parte do risco potencial é suportado pela comunidade: irregularidade da produção natural (variação de safra) e complexidade e custos do processo produtivo;

- Ação paternalista dos programas do governo, com vulnerabilidade quanto à sucessão governamental;

- Mesmo com o melhor valor pago pelo PFNM, a cadeia de valor tradicional e os intermediários continuam ficando com parte da produção; 
- Realização do pagamento a prazo, enquanto o histórico e demanda pelo dinheiro ou insumos são imediatas;

- Falta de preparo gerencial adequado;

- Papel e ação das lideranças comunitárias não foram bem definidos;

- Distribuição desigual de poder entre a empresa e a comunidade;

- Linguagem contratual complexa e não dominada pela comunidade;

- Alta dependência da empresa;

- Intervenções das companhias nas comunidades, que podem prejudicar a organização social tradicional;

- Visão da empresa como um bom intermediário pouca visão para emancipação e autonomia;

- O governo e os comunitários ficam na expectativa que o parceiro comercial realize as obrigações do Estado;

- Direcionamento da força de trabalho sobre uma única ou poucas espécies;

- Risco de redução da força e trabalho para atividades de subsistência;

Scholz (2005) $)^{2}$ apud Ros-Tonen et al. (2008) apresenta a definição de alianças, parcerias e redes utilizada em seu trabalho:

i) alianças - uma atividade comum com foco em um objetivo específico e envolvendo uma variedade de organizações, as quais terminam quando o objetivo foi alcançado; ii) parcerias - uma relação justa e estável entre duas ou mais organizações orientadas por objetivos comuns e baseadas em ideais e visões de mundo compartilhado; e, iii) redes agrupamento maior de organizações, geralmente criadas com o propósito de trocas de informação e algumas vezes com ações conjuntas (SCHOLZ, 2005, apud ROS-TONEN et al., 2008, p. 1483).

${ }^{2}$ SCHOLZ, I. Environmental policy cooperation among organised civil society, national public actors and international actors in the Brazilian Amazon. European Journal of Development Research, v. 17, n. 4, p. 681-705, 2005. 
Assim, para Ros-Tonen et al. (2008) as parcerias são o caminho mais apropriado para a melhoria da governança e manejo florestal, tendo sido estudadas pelos autores em diferentes perspectivas: i) orientadas para produtos; ii) multisetores; e, iii) da sociedade civil. Para os autores cada perspectiva teria uma função para o manejo de florestas, passando pela comercialização dos produtos com acordos e contratos mais vantajosos, pela atuação entre diferentes instituições e setores para melhoria local e pela organização da sociedade civil na realização de lobby e articulações políticas, podendo haver ou não relação entre as mesmas.

Ros-Tonen et al. (2008) conclui que há:

Primeiro, a necessidade de lidar com um número cada vez maior de atores na gestão e governança florestal; segundo, um aumento no escopo da gestão florestal, com a necessidade de maior atenção aos objetivos sociais e outros produtos que não madeira; e, terceiro, a necessidade de lidar com questões mais amplas que a gestão de uma unidade em si, sendo preciso criar um contexto político, legal e institucional apropriado (ROSTONEN et al., 2008, p. 1495).

Assim as parcerias seriam uma importante estratégia para criar situações ganha-ganha, especialmente:

i. Criando um framework institucional para uma perspectiva de multistakeholder para o uso da floresta;

ii. Negociando antecipadamente soluções locais para o uso da terra, que pode colaborar a reduzir reivindicações concorrentes de terras florestais;

iii. Aumentar o envolvimento comunitário na gestão florestal;

iv. Criar situações ganha-ganha e ampliar as capacidades dos atores e escopo de ação através da junção de poder, ativos, conhecimento e técnicas; e,

v. Compensar a falta de políticas específicas através do lobby de condições adequadas para a gestão sustentável de florestas e a aplicação adequada da legislação ambiental e direitos de posse (ROS-TONEN et al., 2008, p. 1495). 
Ingram (2014) contribui com as observações de Ros-Tonen et al. (2008) observando que, dado o contexto sócio-político-econômico das cadeias de valor de PFNM e da governança florestal é necessária a estruturação de arranjos plurais para preencher lacunas e melhorar a ineficiência de processo relacionados à essas cadeias.

Morsello (2006) e Ros-Tonen et al. (2008) apontam alguns fatores importantes para o sucesso de parcerias sendo eles:

- A existência de contratos e mecanismos que permita negociações com objetivos e condições mais justas;

- O processo de capacitação deve iniciar cedo e incluir funções gerenciais, com "empoderamento" das comunidades locais para superar desníveis de poder e interesses divergentes;

- As companhias devem evitar a intromissão em assuntos locais das comunidades;

- A inclusão de brokers, com uma função de controladores e guardiões da parceria, podendo ser constituído pelo governo e terceiros, tais como universidades e ONGs, intervindo quando necessário e também orientando empresas e comunidades;

- Arranjos institucionais equitativos, com boa relação custo-benefício e organização intermediária flexível, capaz de mediar as partes buscando baixos custos de transação;

- Monitoramento constante das condições sociais e ambientais, adaptando a gestão de acordo com esses aspectos;

- Atividades comerciais devem ser planejadas com organização e contemplando a sazonalidade da economia doméstica, assim como os sistemas coletivos de propriedade comum.

Assim, destaca-se a importância de "intermediários" ou brokers entre as demandas empresariais e a manutenção/melhoria da gestão coletiva existente, com ganhos nessa gestão de forma progressiva. Porém, Ribeiro F. (2009), analisando o 
caso da relação entre a empresa Body Shop e os indígenas do médio Xingu através da cooperativa Amazoncoop verificou que os processos de intermediação não garantem necessariamente 0 sucesso da parceria de acordo os fatores sistematizados acima.

Apesar da literatura consultada identificar e avaliar a necessidade de envolvimento de diferentes instituições dentro dos processos de parcerias voltadas aos PFNM, essa não especifica claramente como essas organizações se inseririam no processo e como a gestão dessas parcerias, alianças ou redes deveria ser feita. Assim, torna-se importante o entendimento das relações e das formas de gestão existentes verticalmente, na cadeia de valor, e horizontalmente, entre os diferentes stakeholders do processo.

\subsubsection{Relações na cadeia de valor}

Te Velde et al. (2006) ao realizar estudos em dezenove cadeias de valor de PFNM identificou a presença de diferentes formas de relação e governança dentro destas cadeias e como essa governança pode influenciar a agregação de valor aos produtos. Os autores enfatizam a importância dos agentes empreendedores e argumentam que a ação dos mesmos pode influenciar o sucesso e a existência de mercados para os produtos.

Através do mapeamento ou observação da cadeia é possível fazer uma análise além das fronteiras das comunidades e entender a dinâmica da cadeia como um todo, de forma a direcionar ações que identifiquem os atores-chave e seus papéis, buscando potencializar a cadeia, não necessariamente retirando esses intermediários do processo (TE VELDE et al., 2006; JENSEN, 2009). Te Velde et al. (2006) enfatiza a importância de se realizar um maior controle sobre os impactos negativos e positivos dos atores-chave e empreendedores na cadeia e nas populações tradicionais. É destacado pelos autores que as ações de apoio às cadeias de valor de PFNM devem levar em consideração: 
- Atividades e atitudes de atores-chave;

- Organizações locais que tenham capacidade de oferecer apoio flexível e diferenciado, considerando caso-a-caso;

- Comunidades de produtores podem ser "empoderados" para entender e monitorar o papel dos intermediários, cadeia abaixo;

- As comunidades podem melhorar seu poder de barganha através da obtenção de suporte organizacional e sistemas de informação de mercado;

- Melhora na educação;

- Melhora no acesso ao crédito; e,

- Sistemas mais simples e transparentes de regulação.

Jensen (2009) aponta que há uma grande dificuldade em se conseguir informações e dados das cadeias de PFNM, dado à característica de informalidade e ilegalidade de seus atores (especialmente os intermediários). Isso se fortalece na percepção geral de que alguns atores de algumas cadeias são vistos como "corruptos e fora da lei" (JENSEN, 2009, p. 38).

Marshall, Newton e Schreckenberg (2006), Te Velde et al. (2006) e Jensen (2009) trazem a importância de se entender a dinâmica de funcionamento da cadeia para a proposição de ações de melhoria, considerando as relações internas à comunidade e as relações diádicas com as empresas.

O entendimento da cadeia, dos diferentes atores, das dificuldades de cada "elo", dos valores praticados e das informações de mercado pode favorecer o planejamento de ações de melhoria e controle das cadeias, especialmente quanto aos impactos nas populações tradicionais. A literatura aponta a importância do envolvimento dos stakeholders na cadeia e da estruturação de formas de ação coletivas, porém não traz um olhar mais abrangente de redes e gestão para a promoção das cadeias de valor dos PFNM. 


\subsubsection{Relações em rede}

Dado o pouco material disponível sobre as redes de PFNM optou-se por buscar subsídios e olhares complementares na literatura que enfoca a agricultura familiar, agroecológica e o meio rural. É esperado que essa literatura complemente a escassa literatura de redes para a realidade dos PFNM e das comunidades tradicionais florestais.

Murdoch (2000) avalia a validade da visão de redes para o meio rural, contrastando a mesma a uma perspectiva de desenvolvimento baseada no Estado (mais assistencialista) e outra baseada no mercado (com cadeias de commodities e governança assimétrica). Para o autor a perspectiva de redes (tanto verticais quanto horizontais) é importante para o estudo, entendimento e desenvolvimento rural, e pode ir além da dinâmica do Estado e do mercado. Porém, as redes não são entendidas como uma solução em si e possuem diferentes formatos, sendo necessário "conectar o tipo de rede ao contexto econômico, social, cultural e condições naturais existentes na área rural específica" (MURDOCH, 2000, p. 417).

Abramovay (2000), de forma complementar a Murdoch (2000), coloca que há necessidade de se trazer novas visões propícias ao desenvolvimento rural, especialmente no fortalecimento do capital social dos territórios, muito mais do que em promover o crescimento de atividades econômicas. Segundo Abramovay (2000) o desenvolvimento de distritos industriais ou Arranjos Produtivos Locais, que abordam conceitos de redes, capital social, efeitos de proximidade, podem trazer novas perspectivas para o desenvolvimento regional, fortalecendo o capital social para o protagonismo no direcionamento estratégico.

Murdoch (2000) destaca que as redes horizontais apresentadas na Itália se constituíram a partir da competência dessas comunidades rurais de cooperação e reciprocidade, a qual faz parte de sua história e cultura. Essa relação histórica e cultural se demonstrou importante para a consolidação de redes flexíveis que envolviam produtores, comerciantes, distribuidores e varejistas na busca de novas 
oportunidades, adaptando-se a mudanças de mercado.

Maneschy e Klovdahl (2007) analisam as associações e grupos camponeses na Amazônia Oriental, com uma perspectiva teórica de redes e capital social. Para os autores as associações estão inseridas em uma dinâmica de relações institucionais e de dependência histórica que passa por diferentes instâncias de poder e troca. É destacado o esforço das associações para participarem das mesmas, dada as dificuldades logísticas e de comunicação.

Esses autores ainda observam que áreas com maior diversidade de relações eram aquelas que se relacionavam a "territórios especiais" (áreas protegidas ou de populações tradicionais), "sobre as quais convergem interesses e atores cujas conexões se estendem até o plano internacional" (IBID, p. 14). Nessas regiões, em que há pouca presença do Estado e baixo acesso aos serviços básicos, as conexões sociais são de especial importância para as associações alcançarem seus objetivos (IBID).

Destaca-se que "barreiras concretas de comunicação reduziam a habilidade da rede em difundir os eventuais benefícios desses fluxos" (IBID, p. 15), dificultando a difusão de informação, contato, negociações e trocas com as instituições regionais. Para os autores a superação dessa barreira e o fomento do encontro entre as associações e grupos similares poderiam estimular a formação de um capital social local mais ativo, concluindo:

Por certo, tal resultado requer bem mais que esforços para desenvolver as capacidades relacionais. Requer também, como se viu, atenção às condições sociais herdadas e seus efeitos diferenciais sobre as organizações, seus parceiros e modalidades de intercâmbio. De um lado, considerar como novas associações se coadunam, ou não, com padrões costumeiros de ação coletiva nas comunidades rurais, se há imposição de padrões, sobreposição ou conflitos de interesses. De outro, o conjunto de fatores econômicos, políticos e ambientais que restringem não só as capacidades relacionais, como reforçam a submissão dos locais a agentes externos e sua posição subalterna em redes econômicas e políticas e que, no limite, ameaçam a permanência das categorias sociais chamadas a se associar. (MANESCHY; KLOVDAHL, 2007, p. 16) 
Assim, para Maneschy e Klovdahl (2007), é importante a promoção e fortalecimento do encontro entre atores locais, com o entendimento das relações históricas e o cuidado de não se reproduzir estruturas subalternas para as populações campesinas em redes políticas, econômicas e de agentes externos.

Becker e Lená (2003) estudam os pequenos empreendimentos alternativos na Amazônia, com um enfoque nos projetos estruturados por parcerias ligadas aos PDAs. O estudo mostra a relação interinstitucional existente dentro do programa e analisa alguns projetos, sem, no entanto, entrar nas estruturas de gestão das diferentes redes.

Ao buscar e analisar esses empreendimentos Becker e Lená (2003) destacam a existência de uma grande quantidade de empreendimentos e pequenos projetos e a multiplicidade e diversidade de redes de apoio associada aos mesmos, com duas escalas diferentes de intervenção: a escala local (normalmente associada à ONGs de pequeno porte), caracterizada pelo apoio a um projeto em particular, e uma escala mais geral (associada à ONGs, instituições e redes maiores), que visa desenvolver mecanismos que facilitem iniciativas e promovam pequenos empreendimentos, independentemente do lugar.

Becker e Lená (2003) destacam que apesar dos ganhos os projetos enfrentam problemas quanto a questões internas e falta de formação. "A capacitação, a interiorização dos valores e mecanismos da economia de mercado e da gestão cooperativa são processos lentos e o crescimento dos empreendimentos é rápido demais" (IBID, p. 413).

Apesar da estruturação dos projetos do PDA ter o apoio de instituições diversas, o que se percebe nos estudos de Becker e Lená (2003) é que poucas conseguiram se organizar em rede com uma estrutura de mais longo prazo. Becker e Lená (2003) apontam um diferencial quanto à organização da Rede Frutos do Cerrado (RFC), sendo considerado como um dos projetos mais bem sucedidos, e concluem: 
de desenvolvimento, sendo imprescindível que se juntem para atuar na escala microrregional e regional. A organização em rede parece ser fundamental para o relativo sucesso dos empreendimentos. Não se trata apenas da constituição de vários projetos e de mais ampla escala, mas sim de sua articulação mediante princípios e diretrizes comuns definidas de forma coletiva, tal como ocorre na RFC. O adensamento criado pela escala e a articulação em rede representa uma grande potencialidade, favorecendo o beneficiamento da produção e a agregação de valor aos produtos (BECKER; LÉNA, 2003, p. 419).

O que se percebe a partir da literatura consultada (das relações empresascomunidades, de cadeia de valor e de redes) é que há uma lacuna quanto a estudos sobre as redes de PFNM e quanto aos processos de gestão dessas redes.

De forma complementar às redes de PFNM, foram identificadas duas redes de suporte a produção e comercialização de produtos agroecológicos e agroextrativistas, na região sul (Rede Ecovida) e centro-oeste (Rede de Comercialização Solidária de Agricultores Familiares e Extrativistas do Cerrado). Apesar de apresentarem realidades distintas quanto ao contexto regional, organização social, comunicação e logística, essas redes se encontram mais próximas da realidade extrativista do que as redes empresariais, podendo contribuir no entendimento de estruturas e organização das redes de PFNM. Através da consulta ao material produzido sobre essas redes, busca-se o entendimento do funcionamento, organização e estrutura de gestão e governança das mesmas.

\subsubsection{Rede Ecovida}

A Rede Ecovida, fundada em 1998 em Santa Catarina, é uma organização de produtores agroecológicos, instituições de apoio (ONGs, associações, sindicatos, cooperativas) e consumidores que está localizada nos três estados do Sul do país. A Rede se divide em 23 núcleos regionais em 170 municípios e conta com aproximadamente 200 grupos de agricultores, 20 ONGs e 10 cooperativas de agricultores (ECOVIDA, 2012). Atualmente a rede se estrutura juridicamente como 
uma associação, sendo esta regulamentada pelo MAPA (Ministério de Agricultura, Pecuária e Abastecimento) como Organismo Participativo de Avaliação de Conformidade (Opac), responsável pelo Sistema Participativo de Garantia (SPG) de produtos orgânicos da rede.

Segundo Santos (2005) a rede entende a comercialização como um dos gargalos para a agricultura ecológica. Assim, os objetivos centrais da rede estão na melhoria da produção, divulgação de produtos ecológicos (entre produtores e consumidores) e na comercialização destes produtos. A rede busca divulgar a produção agroecológica entre os produtores ao mesmo tempo em que busca inserir mais consumidores, objetivando não levar seus produtos apenas para nichos de mercado (SANTOS, 2005).

\section{Objetivos, valores e princípios da rede Ecovida.}

A rede Ecovida transmite como mensagem e dá como garantia a produção de alimentos saudáveis, que respeitam o meio-ambiente e as pessoas, conectando de forma justa produtores e consumidores dentro dos princípios da economia solidária e da agroecologia (ECOVIDA, 2012).

O funcionamento da rede e de seu sistema de garantia ocorre através da promoção de: confiança, participação, descentralização, organização de base, formação de redes, transparência, olhar externo, adequação a produção familiar e processos pedagógicos.

Os princípios da rede são:

- Ter na agroecologia a base para o desenvolvimento sustentável;

- Trabalhar com agricultores e agricultoras familiares e suas organizações;

- Ser orientada por normativa própria de funcionamento e de produção;

- Trabalhar na construção de mercado justo e solidário; 
- Garantir a qualidade através da certificação participativa (ECOVIDA, 2012).

E seus objetivos são:

- Desenvolver e multiplicar as iniciativas agroecológicas;

- Incentivar o associativismo na produção e no consumo de produtos ecológicos;

- Gerar, articular e disponibilizar informações entre organizações e pessoas;

- Aproximar, de forma solidária, os agricultores e os consumidores;

- Ter uma marca e um selo que expressam o processo, o compromisso e a qualidade;

- Fomentar o intercâmbio, o resgate e a valorização do saber popular (ECOVIDA, 2012).

\section{Estrutura de gestão, governança e coordenação da rede Ecovida.}

Segundo Medaets (2003) e Medaets e Medeiros (2004), o sistema de gestão da Ecovida promove a Certificação Participativa em Rede (CPR), fornece assistência técnica e apoia a comercialização dos produtos. A estrutura da rede é organizada para promover a qualificação e expansão da produção agroecológica, garantir a qualidade dos produtos e processos e integrar produtores e mercado.

De acordo com Santos (2005) e Medaets e Medeiros (2004) a rede Ecovida é uma associação dividida em Núcleos Regionais (NR), os quais contam com o suporte técnico de ONGs (pelo menos uma por núcleo). Estes núcleos estão divididos em grupos de produtores e se ligam ao mercado através de feiras municipais e cooperativas de consumidores. Os coordenadores da rede Ecovida são escolhidos nos encontros ampliados da rede a cada dois anos. A Figura 3 sintetiza a estrutura organizacional da rede e a Figura 4 descreve as principais responsabilidades dos diferentes nós. 


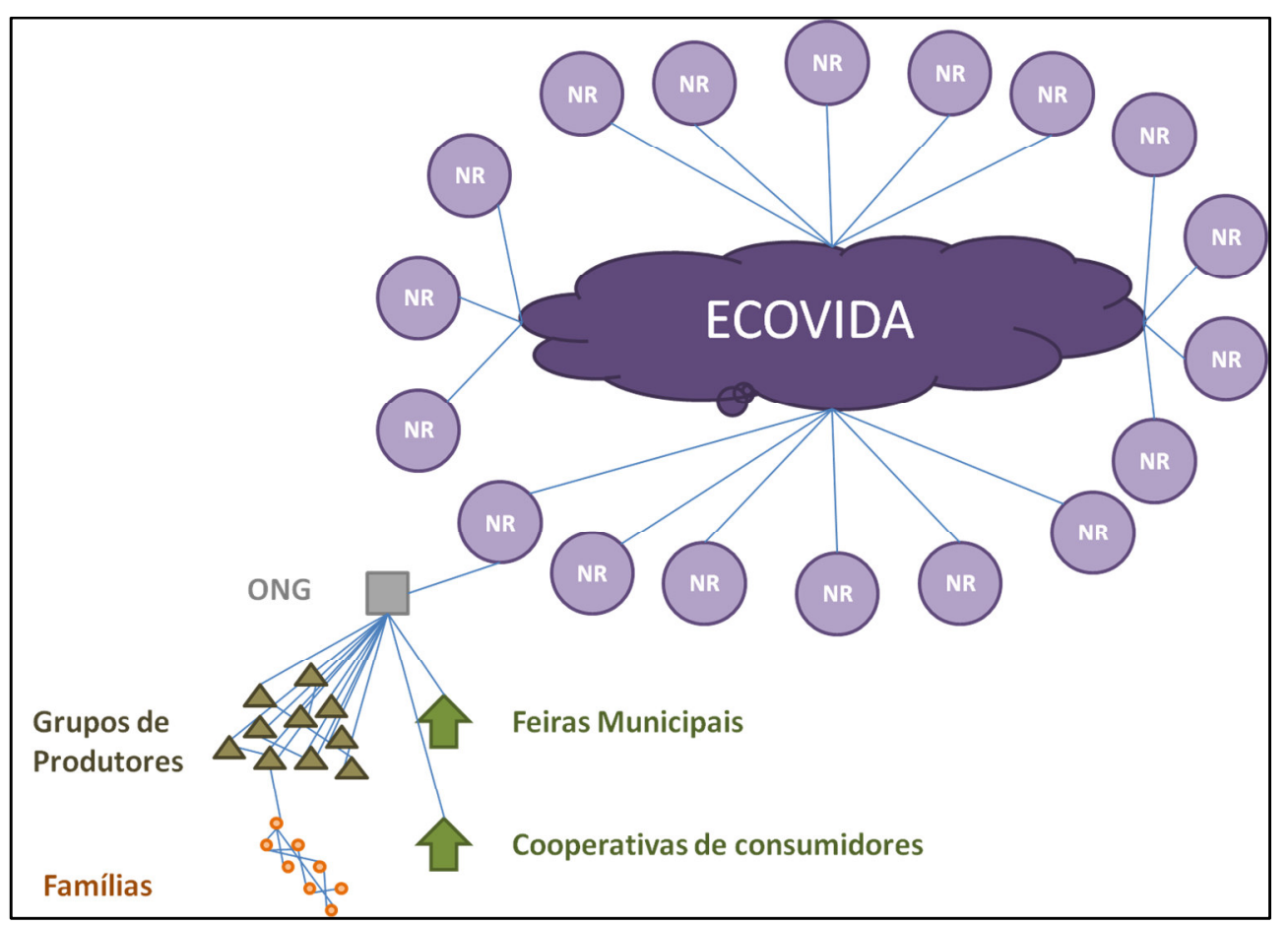

Figura 3: Estrutura de gestão da rede Ecovida.

Fonte: Autoria própria com base em Medaets (2003), Medaets e Medeiros (2004) e Santos (2005).

- - Doordenação geral da rede;
- $\begin{aligned} & \text { - Realiza um encontro ampliado de } 2 \text { em } 2 \text { anos; } \\ & \text { - Disponibiliza material e padröes gerais; } \\ & \text { - Não existia juridicamente e agora é uma associação e Opac. } \\ & \text { - Coordenação regional da rede; } \\ & \text { - Define regras, acordos e normas regionais (Padrões e normas podem ser } \\ & \text { adaptados ao contexto e práticas regionais); } \\ & \text { - Delibera sobre entrada e saída de membros e sobre os pedidos de } \\ & \text { liberação do uso do selo; } \\ & \text { - Reúne-se pelo menos duas vezes no ano; } \\ & \text { - Possui as seguintes estruturas: } \\ & \text { - Conselho de ética; } \\ & \text { - Secretário do Núcleo; } \\ & \text { - Tesoureiro; } \\ & \text { - Financiamento através de anuidades (50\% para o NR e 50\% Rede). }\end{aligned}$
$\begin{aligned} & \text { - Coordenação regional da rede } \\ & \text { - Instituição responsável pela assistência técnica e pela animação e } \\ & \text { coordenação do processo de cooperação do Núcleo Regional; }\end{aligned}$
$\begin{aligned} & \text { - Grupos locais que reúnem as famílias ; } \\ & \text { - Aplicam os procedimentos e padrões para a certificação; } \\ & \text { - Multiplicam e trocam experiências e boas práticas; } \\ & \text { - Aprovam a entrada e saída de famílias; } \\ & \text { - Indicam a designação do selo para as famílias. }\end{aligned}$
$\begin{aligned} & \text { - Responsáveis pela produção e por seguirem os padrões acordados; } \\ & \text { - trocam experiência e monitoram uns aos outros. }\end{aligned}$

Figura 4: Papéis e organização da rede Ecovida.

Fonte: Autoria própria com base em Medaets (2003), Medaets e Medeiros (2004) e Santos (2005). 
Segundo Medaets e Medeiros (2004), os processos de monitoramento e controle buscam garantir a qualidade e a conformidade dos processos produtivos dentro da SPG. Para os SPG esta conformidade se caracterizaria por uma "conformidade social", que se dá pela participação dos cidadãos na construção do bem coletivo e pelo cumprimento das normas e acordos firmados para o funcionamento do sistema de garantia (MEDAETS; MEDEIROS, 2004).

\subsubsection{Rede de Comercialização Solidária de Agricultores Familiares e Extrativistas do Cerrado.}

Segundo Silva e Porto-Gonçalvez (2008) a Rede de Comercialização Solidária de Agricultores Familiares e Extrativistas do Cerrado foi criada em 2000 e conta com duas cooperativas, a Coopcerrado e a Rede Cred, e uma marca própria, o Empório do Cerrado. A rede se organiza em três territórios (Goiano, Mineiro e Nordeste) e através 83 comunidades territoriais. O território Goiano é constituído de 9 municípios, 16 comunidades e 365 famílias (e provavelmente 73 núcleos). O território Nordeste é formado por 10 municípios, 37 comunidades e 405 famílias (e provavelmente 81 núcleos). O território Mineiro é formado por 11 municípios, 34 comunidades e 448 famílias (e provavelmente 90 núcleos). Toda a rede recebe assessoria da ONG CEDAC (Centro de Desenvolvimento Agroecológico do Cerrado), com sede em Goiânia, a qual assessora os diferentes espaços políticos, administrativos, de produção, de comercialização e de formação da rede.

A rede conta com uma marca própria (Figura 5) e um website para a comercialização de seus produtos industrializados (http://loja.emporiodocerrado.org.br/). Além da comercialização direta pela internet a rede possui contratos de fornecimento de matéria prima para indústria, como no caso especifico da fava d'anta ou faveira (Dimorphandra $s p$ ) para a indústria Merck Maranhão (OLIVEIRA; HESPANHOL, 2011) e para o mercado institucional, como da merenda regionalizada (SILVA; EGITO, 2005). 


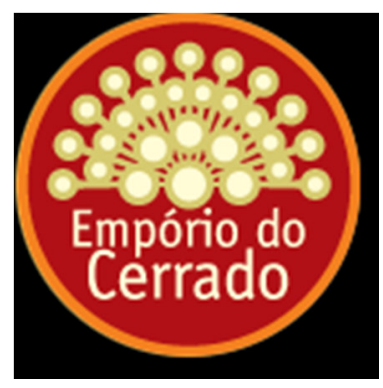

Figura 5: Selo Empório do Cerrado.

\section{Objetivos, valores e princípios da rede de comercialização.}

Segundo Empório do Cerrado (2012), a Rede de Comercialização Solidária de Agricultores Familiares e Extrativistas do Cerrado tem como objetivo central a promoção das comunidades e produtos do cerrado através do "protagonismo técnico e político dos agroextrativistas", com a agregação de valor aos produtos do cerrado (comercialização, marca própria, industrialização). O enfoque técnico e de formação ocorrem através da agroecologia e de processos e empreendimentos autogestionários.

Além das questões de comercialização, a rede possui uma visão mais ampla de territorialidade e de busca por direitos básicos da população a ela vinculada, buscando a criação de dez Reservas Extrativistas (EMPÓRIO DO CERRADO, 2012). São conquistas da rede, segundo Empório do Cerrado (2012):

- Criação da portaria 18/2002-N da Agência Goiana de Meio Ambiente, que proíbe o corte do Baru (Dipteryx alata) no estado de Goiás;

- Aprovação da Lei nำ15.051, de 29 de dezembro de 2004, que trata da matéria tributária dispondo sobre a redução de base de cálculo do Imposto de Circulação de Mercadoria e Serviços (ICMS) sobre a industrialização de produtos típicos do cerrado (antes era $17 \%$ e com a lei passou para $7 \%$ ). Foi resultado das reivindicações da Rede junto ao Governo de Goiás;

- Elaboração de Projeto de Lei para Proteção do Baru, no município de Lassance/MG, baseado na portaria de proibição do corte do baru no estado de Goiás;

- Comodato de áreas públicas para construção de unidades territoriais de armazenamento: nos Municípios de São 
Domingos/GO, Ibiaí/MG, Paracatu/MG, Goiás/GO, Goiânia/GO e Jandaia/GO;

- Viabilização pelo processo em rede ao acesso coletivo aos recursos públicos (PRONAT- Programa Nacional de Desenvolvimento Sustentável de Territórios Rurais) para construção de agroindústrias: Entreposto de Produtos Apícolas e Usina de Óleos Vegetais;

- Alimentação escolar, introdução de produtos regionais agroextrativistas (baru e jatobá) no cardápio de 513 instituições de 15 municípios do estado de Goiás, através da comercialização de cookies e granolas de baru e jatobá, mel e gergelim pelo Programa de Aquisição de Alimentos, do Fome Zero via CONAB;

- Reconhecimento da Rede pelo Ministério do Desenvolvimento Agrário - MDA, como instituição implementadora de Assistência Técnica - ATER;

- A Rede foi um dos estudos de caso piloto do FACES do Brasil Fórum de Articulação do Comércio Ético e Solidário que contribuiu para a construção do sistema nacional de comércio justo, ético e solidário;

- Constituição da Rede Cred - Cooperativa de Crédito Solidário da Rede de Comercialização Solidária, autorizado pelo Banco Central em novembro de 2006;

Os princípios norteadores da rede são, segundo Empório do Cerrado (2012):

"Respeitar o Cerrado".

- não praticando queimadas;

- coletando apenas frutos caídos no chão e deixando parte dos frutos para os animais;

- não derrubando os frutos com vara ou qualquer outro instrumento;

- cultivando roças de forma ecológica, garantindo a diversidade biológica e autonomia dos agroextrativistas.

"Garantir o desenvolvimento com democracia e justiça".

- não explorando outros agroextrativistas, através da prática de compra de frutos, ou mesmo a contratação de mão-de-obra para a coleta;

- o trabalho deve ser familiar, sem a participação de crianças de até 14 anos em atividade que possam comprometer a sua integridade física, moral e intelectual, e os adolescentes participantes devem estar freqüentando a escola; 
- a participação das mulheres com direitos iguais;

- estabelecendo um preço justo e estimulando o consumo sustentável.

"Fortalecer a identidade dos agroextrativistas do Cerrado".

- valorizando seu conhecimento tradicional, como forma de sobrevivência e autonomia;

- com a participação de famílias que realizam atividades como agricultura, extrativismo e pesca sob regime de economia familiar;

- lutando pela garantia dos meios de reprodução social, como a terra, a água e a biodiversidade do cerrado.

\section{Estrutura de Gestão, governança e coordenação da rede de comercialização.}

Segundo Silva e Porto-Gonçalves (2008) a rede de comercialização tem como organização central as Assembleias Gerais e o Conselho Político, do qual fazem parte representantes dos 3 Territórios e os diretores da Coopcerrado e da Rede Cred, em um total de 18 conselheiros. Os Territórios são divididos em Territórios Comunitários, os quais concentram os Núcleos Familiares, que por sua vez são formados por 5 a 7 famílias e possuem um monitor escolhido dentro das famílias do núcleo.

Este monitor participa de um processo de formação (chamado de formação de agroextrativista a agroextrativista) em sistema de alternância no Centro de Formação em Agroecologia em Goiânia. Dado o número de famílias atendidas por cada monitor ( 5 aproximadamente) e o total de famílias, considera-se a existência de aproximadamente 244 monitores atendendo 1218 famílias em 2008. A Figura 6 sintetiza a estrutura organizacional da rede de comercialização. 


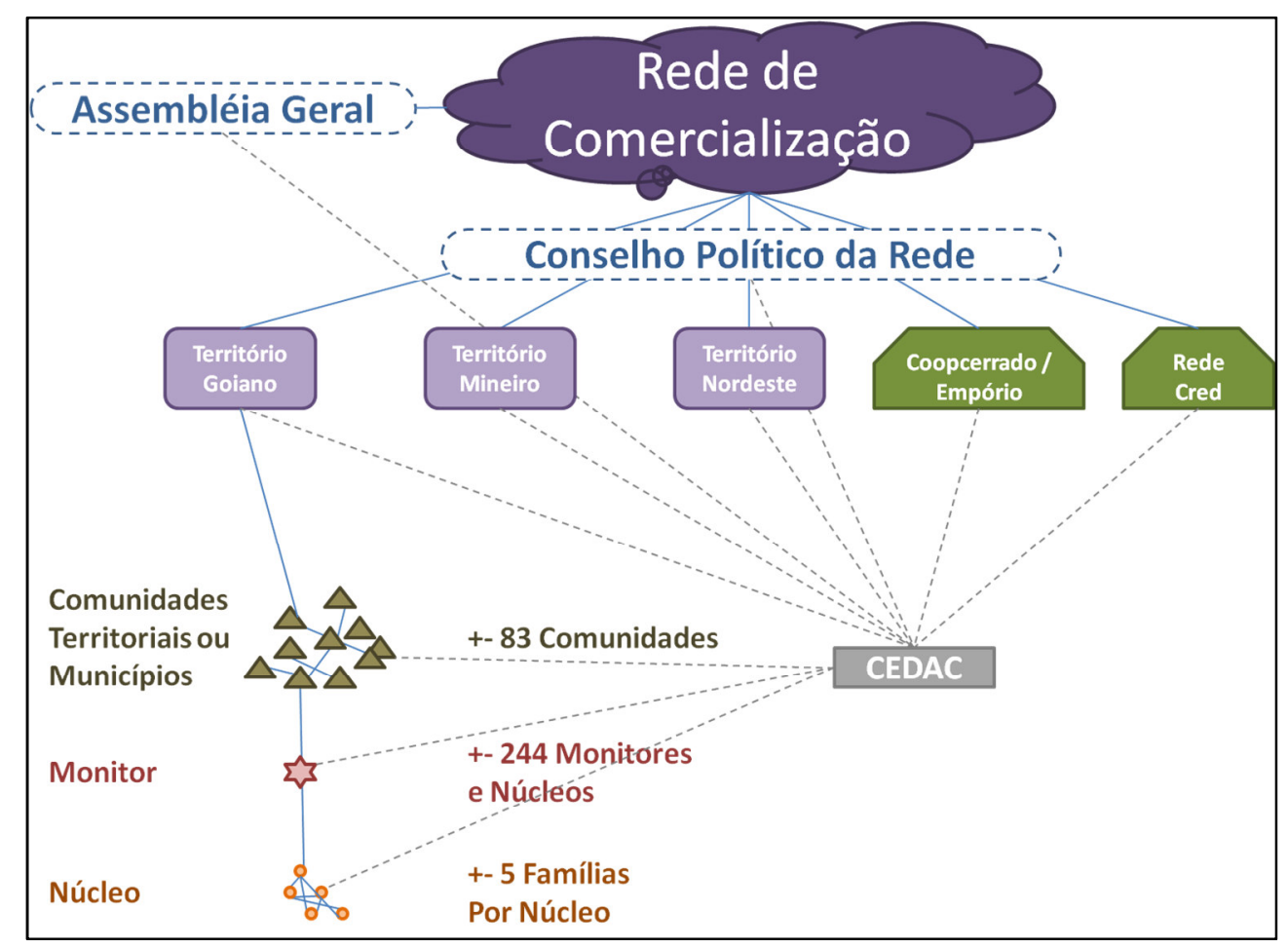

Figura 6: Estrutura de Gestão Rede de Comercialização do Cerrado.

Fonte: Adaptado de Silva e Porto-Gonçalvez (2008), Silva e Egito (2005) e Rede de Comercialização Solidária (s/d).

Abaixo segue a descrição dos diferentes papéis e espaços de gestão da rede com base em Rede de Comercialização Solidária (s/d), Silva e Porto-Gonçalvez (2008) e Silva e Egito (2005).

- Assembleia: É a instância de decisão máxima da Rede de Comercialização Solidária de Agricultores Familiares e Extrativistas do Cerrado, onde são definidas as estratégias para o plano de ação bianual da Rede, eleitos os conselheiros políticos da rede, os diretores da Coopcerrado e da Rede Cred e realizadas alterações no estatuto e regimento interno;

- Fóruns territoriais: Os fóruns são espaços de preparação e mobilização que antecedem a Assembleia da Rede, realizados a cada dois anos em três territórios (Goiano, Mineiro e o Nordeste), cujo objetivo é avaliar o trabalho em curso, discutir estratégias, trocar conhecimentos e construir o planejamento participativo com as comunidades. Os fóruns são discutidos e preparados antecipadamente pelas comunidades a partir de um roteiro definido pelo conselho político da Rede, que permite além da participação efetiva da 
comunidade de opinar e avaliar o trabalho, bem como indicar três representantes da comunidade para participar dos Fóruns e defender suas propostas coletivas.

- Conselho político da rede: formado pela diretoria da COOPCERRADO, pela diretoria da Rede Cred, e por três representantes de cada território (Nordeste, Goiano, Mineiro). É responsável pela: Gerência de Comercialização; Gerência Administrativa; Gerência de Crédito.

- Núcleos familiares: são formados por cinco a sete famílias, sendo responsáveis pela estruturação de acordos, planejamentos e procedimentos da produção. São responsáveis pela produção dos produtos para a rede. Cada núcleo tem um monitor que recebe formação em alternância por dois anos e presta assistência técnica para as famílias, apoia no planejamento de safra e na estruturação de planos de manejo familiares;

- Monitores: a formação do monitor como técnico é um dos enfoques da rede. O monitor é responsável pela assistência técnica de campo, pelo suporte ao planejamento familiar e comunitário e pela mobilização comunitária;

- Comunidades Territoriais: concentração de diferentes núcleos em comunidades com reuniões bimensais dos monitores para planejamento, articulações e troca de experiências;

- Municípios: reuniões semestrais dos monitores no nível de município para planejamentos conjuntos, articulações a nível municipal e troca de experiências;

- CEDAC: Centro de Desenvolvimento Agroecológico do Cerrado (entidade que assessoria da Rede). É a instituição animadora e articuladora da rede, centralizando a organização das ações junto aos diferentes espaços de decisão, articulação entre os produtores e também interinstitucional, a captação de recursos, a formação e assistência técnica.

\subsection{Plano Nacional de Promoção das Cadeias da Sociobiodiversidade}

O Plano Nacional de Promoção das Cadeias da Sociobiodiversidade (PNPSB), 
publicado em 2009, tem coordenação interministerial, envolvendo o Ministério do Desenvolvimento Agrário (MDA), o Ministério do Meio Ambiente (MMA) e o Ministério de Desenvolvimento Social (MDS). O plano busca fortalecer as cadeias de produtos da sociobiodiversidade, envolvendo em sua elaboração comunidades, cooperativas, empresas privadas, governos (Federal, Estadual e Municipal), universidades e organizações não governamentais (BRASIL, 2008a, 2008b, 2009).

Com base nos documentos publicados pelo PNPSB (BRASIL, 2008a; 2008b; 2009a; 2009b, 2010), percebe-se que o governo busca estruturar suas ações em diferentes níveis político-econômicos, de forma similar ao proposto por MeyerStamer (2001). No nível Macro estão sendo pensados novos programas, incentivos, políticas e legislações que favoreçam as cadeias da sociobiodiversidade. No nível Meso, estão sendo feitas diferentes articulações políticas entre os estados, ministérios, municípios, instituições de apoio, universidades e instituições comunitárias para diagnóstico e melhoria das cadeias. No nível Micro, as ações realizadas até 2010 foram pontuais e focadas em atores específicos, sendo planejada a estruturação de APLs em diferentes territórios, com articulação entre os diferentes stakeholders das cadeias produtivas.

Os APLs e as cadeias produtivas da sociobiodiversidade são definidos no PNPSB como:

Arranjos Produtivos Locais: Agrupamentos de empreendimentos de um mesmo ramo, localizados em um mesmo território, que mantêm algum nível de articulação, interação, cooperação e aprendizagem entre si e com os demais atores locais (governo, pesquisa, ensino, instituições de crédito) (BRASIL, 2009a).

Cadeia Produtiva da Sociobiodiversidade: Um sistema integrado, constituído por atores interdependentes e por uma sucessão de processos de educação, pesquisa, manejo, produção, beneficiamento, distribuição, comercialização e consumo de produto e serviços da sociobiodiversidade, com identidade cultural e incorporação de valores e saberes locais e que asseguram a distribuição justa e equitativa dos seus benefícios (IBID).

O objetivo geral do PNPSB é "desenvolver ações integradas para a promoção e fortalecimento das cadeias de produtos da sociobiodiversidade, com agregação de valor e consolidação de mercados sustentáveis" (BRASIL, 2009a). Como objetivos específicos o plano propõe: 
- Promover a conservação, o manejo e o uso sustentável dos produtos da sociobiodiversidade;

- Fortalecer cadeias produtivas em cada um dos biomas agregando valor aos produtos da sociobiodiversidade;

- Fortalecer a organização social e produtiva dos povos indígenas, quilombolas, comunidades tradicionais e agricultores familiares;

- Ampliar, fortalecer e articular instrumentos econômicos necessários à estruturação das cadeias produtivas;

- Fortalecer redes de conhecimento integrando as ações de pesquisa, assistência técnica e capacitação;

- Fortalecer a articulação intra/interinstitucional e intersetorial;

- Adequar o marco legal de maneira a atender as especificidades dos produtos da sociobiodiversidade (BRASIL, 2009a).

\section{Como diretrizes estratégicas, o PNPSB busca:}

(i) Promover a conservação e uso sustentável da biodiversidade;

(ii) Promover o reconhecimento do direito dos povos indígenas, quilombolas, comunidades tradicionais e agricultores familiares ao acesso aos recursos da biodiversidade e à repartição justa e eqüitativa de benefícios;

(iii) Promover a valorização e respeito da diversidade cultural e conhecimento tradicional;

(iv) Promover a segurança alimentar e nutricional a partir da alimentação diversificada;

(v) Buscar a agregação de valor socioambiental, com geração de emprego, renda e inclusão social;

(vi) Construir e consolidar mercados regidos por valores de cooperação, solidariedade e ética; 
(vii) Adotar a abordagem de cadeias e arranjos produtivos, o enfoque participativo, territorial e sistêmico como elementos de concepção e implementação do Plano;

(viii) Promover o empoderamento e controle social;

(ix) Promover a articulação intra e interinstitucional, e intersetorial;

(x) Implementar uma estrutura de gestão com base no compartilhamento de responsabilidades entre os setores público, privado e a sociedade civil organizada (BRASIL, 2009a).

O PNPSB parte da organização interministerial e se propõe a estruturar políticas e ações de forma articulada com governos estaduais, municipais, povos tradicionais e a sociedade civil organizada. De acordo com Brasil (2009a) a estrutura de execução do plano se organiza em uma instância deliberativa e instâncias consultivas.

Instância deliberativa:

- Coordenação Geral: MDA, MMA, MDS;

- Abrangência: Nacional;

- Atribuições:

- Articulação das ações do PNPSB;

- Operacionalização e implementação das ações;

- Articulação das estâncias estaduais e locais quando necessário;

- Organização e viabilização da coordenação e dos colaboradores de cada eixo de ação que compõem este plano de cada cadeia;

- Acompanhar a implantação dos planos de trabalho junto as cadeias de produtos da sociobiodiverside.

Instâncias consultivas:

- Câmara Setorial Nacional por Cadeia Prioritária, Câmaras Estaduais, APL, GTs;

- Abrangência: Nacional, regional e local;

- Caráter: Multissetorial; 
- Atribuições:

○ formulação e proposição;

- planejamento, acompanhamento e avaliação do andamento do Plano;

- definição de prioridades e critérios para reconhecimento das Estruturas

A Figura 7 sintetiza a estrutura político-administrativa do PNPSB, trazendo possíveis fluxos de informação, políticas, estratégias e ações.

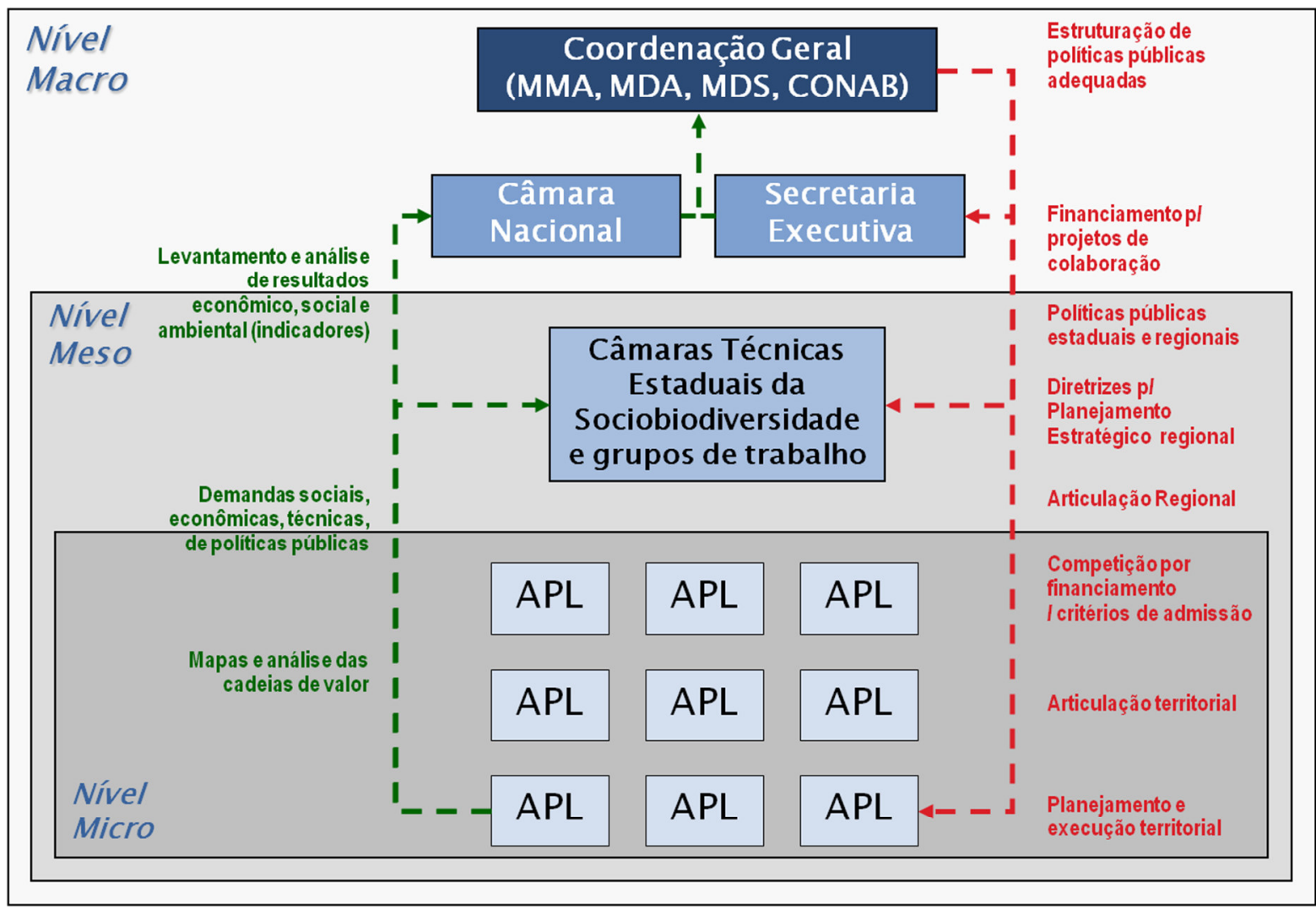

Figura 7: Estrutura político-administrativa do PNPSB.

Fonte: Autoria própria.

Dentro da instância consultiva foram criados até 2010 fóruns nacionais e estaduais para o diálogo sobre as diferentes cadeias de produtos da sociobiodiversidade, sendo estes: câmara nacional da sociobiodiversidade; dez câmaras estaduais da sociobiodiversidade (AC, AM, RO, MT, AP, PA, MA, TO, PI e CE); e fóruns técnicos específicos para cada cadeia/produto (BRASIL, 2010).

No final de 2011 foram lançados editais para contratar instituições sem fins 
lucrativos que atuem na promoção de dez APLs, sendo eles: Amazonas - APL Piaçava; Bahia - APL da piaçava; Ceará - APL do babaçu e pequi; Pará - APL do Açaí e Andiroba; Pará - APL castanha do Brasil e copaíba; Pará - BR 163 APL óleos vegetais e castanha do Brasil; Piauí , Maranhão e Minas Gerais - APL pequi e frutos do cerrado(BRASIL, 2011).

De acordo com Brasil (2010) algumas ações iniciadas e em andamento pelo PNPSB são:

- Definição das cadeias prioritárias;

- Inserção de produtos da sociobiodiversidade no Programa de Aquisição de Alimentos (PAA) ${ }^{3}$ e no Programa de Garantia do Preço Mínimo (PGPM) ${ }^{4}$ coordenados pela CONAB (Companhia Nacional de Abastecimento).

- Inserção dos produtos da sociobiodiversidade no programa de merenda escolar regionalizada, através do Progama Nacional de Alimentação Escolar (PNAE). ${ }^{5}$

- Formações técnicas e início da estruturação da rede de serviços;

- Instituição e formalização das Câmaras Setoriais;

- Estruturação das boas práticas de manejo para alguns produtos;

${ }^{3}$ O PAA é um programa federal para a aquisição de alimentos que se divide em duas linhas de atuação: de formação de estoque e de doação simultânea. Através da linha de formação de estoque, o produtor (da agricultura familiar ou extrativista) consegue recursos da Conab para formar estoque de produtos para o beneficiamento ou comercialização futura. Já a linha de doação simultânea possibilita a compra através da Conab de produtos alimentícios de produtores para a doação a instituições civis ou públicas.

${ }^{4} \mathrm{O}$ PGPM é um programa federal que estipula um valor minimo para uma série de produtos agrícolas e da sociobiodiversidade. Caso os produtores vendam seus produtos por valores abaixo desse valor mínimo determinado, eles podem requerer a diferença junto à Conab.

${ }^{5}$ O PNAE é uma política pública federal que obriga as prefeituras a comprarem pelo menos $30 \%$ dos alimentos da agricultura familiar ou extrativista para merenda escolar. 
- Comunidades Virtuais para troca de informação e disponibilização de materiais;

- Realização de reuniões com o setor empresarial e participação em feiras de negócio.

Há, assim, um esforço e ações estruturadas para os níveis macro e meso das políticas públicas e o início da organização dos APLs. Há ainda poucas ações no nível micro em termos de organização interinstitucional e de implantação das ações propostas pelo plano. Dessa forma, espera-se que as análises realizadas pela pesquisa contribuam na identificação, organização e coordenação das ações no nível micro, de forma articulada com os fóruns e políticas estruturadas nos níveis meso e macro.

\subsection{Redes de Cooperação}

A cooperação interorganizacional é um fenômeno atual e presente na rotina das organizações e governos em todo o mundo. Porém, Provan, Fish e Sydow (2007), ao analisar a literatura de redes interorganizacionais, demonstraram que as formas de colaboração são poucas vezes pesquisadas sobre a perspectiva teórica de redes, sendo mais comum a descrição e estudos através de parcerias, alianças estratégicas, relações interorganizacionais, coalizões e acordos cooperativos.

Provan, Fish e Sydow (2007) indicaram a importância de se estudar as redes interorganizacionais de forma integral, que classificam como whole network. Essa abordagem mais holística de entendimento das redes é apontada pelos autores como uma área ainda pouco estudada, sendo que os enfoques dos estudos pesquisados se concentram mais nas relações diádicas ou mesmo na relação de uma organização com a rede. Para os autores essa visão mais holística de redes pode facilitar o entendimento de algumas questões, tais como: a evolução das redes; a governança; formas de gerar resultados coletivos; o impacto e formas de melhorias da colaboração multilateral em uma região; formas de se conseguir a 
inovação multi-firmas; melhoria de clusters de pequenas empresas; estruturação de redes para melhoria de desempenho.

Oliver e Ebers (1998) realizaram uma revisão estruturada e analítica de parte da literatura sobre relações interorganizacionais e redes e observaram que o campo de redes é um campo multidisciplinar. Este possui algumas teorias centrais, com alguma convergência na conceituação de redes, porém segmentado por um número grande de perspectivas teóricas. Algumas dessas perspectivas são apresentadas no Quadro 3.

Quadro 3: Perspectivas teóricas para redes interorganizacionais.

\section{Perspectivas teóricas Descrição}

Foco na medição comparativa dos custos de transação, relativos

Custo Transacional

Estratégia

Institucional

Ecologia de população a transações entre diferentes arranjos institucionais. Sobre este ponto de vista a cooperação seria uma forma de organização híbrida entre o mercado e as empresas.

Foco em como as estratégias institucionais impactam nas redes e relações interorganizacionais ou em como os resultados/efeitos das relações interorganizacionais afetam a posição estratégica da organização e a vantagem comparativa.

Foco em processos que levam à conformidade, ordens institucionalizadas, ou similaridades entre as organizações, assim as legitimando.

Foco em como a "seleção natural/ambiental" resulta na extinção de certas formas organizacionais, ou como oportunidades do ambiente permitem 0 surgimento de novas formas organizacionais.

Foco no processo pelo qual organizações reduzem suas dependências do ambiente utilizando diferentes estratégias que aumentam seu poder dentro do sistema interorganizacional.

\section{Estruturação}

Foco na ação recíproca de estruturas e ações na geração de 
ordem

\section{Rede sociais}

Tomada de decisão

Intercâmbio

Organizações

industriais

Evolucionário

Poder político

Barganha

Agência

Teoria dos Jogos
Foco em como o posicionamento dos atores dentro de suas redes de relações, e o conteúdo dessas relações, afetam suas oportunidades para a ação.

Foco no processo interno de tomada de decisão da organizaçãoe como estes impactam os padrões interorganizacionais de relação, direcionamentos políticos, ações políticas, etc.

Foco em como características dos processos de intercâmbio/troca estão relacionados com o conteúdo e estrutura das relações interorganizacionais.

Foco em como as estruturas de mercado (e.g. número de compradores e vendedores, grau de diferenciação dos produtos, barreiras de entradas, etc.) afetam a formação e padrões das relações interorganizacionais e vice-versa.

Foco no processo através do qual os padrões das relações interorganizacionais evoluem, são mantidas e se modificam.

Foco em como relações interorganizacionais promovem ou impedem o uso do poder e vice versa.

Foco no processo pelo qual grupos e indivíduos buscam seus interesses em sistemas de troca.

Foco nos arranjos institucionais em que os atores criam suas agências de relação de forma a buscar seus interesses próprios em condições de divergência de interesses e assimetria de informação.

Foco nos modelos matemáticos projetados para analisar a interação entre diferentes atores dos quais as decisões afetam uns aos outros. Dessa perspectiva a cooperação ocorreria quando as vantagens da cooperação sobressaíssem à soma 
das vantagens individuais.

Foco em sistemas que demonstram estruturas complexas no tempo ou espaço, normalmente ocultando regras determinísticas

Sistemas Complexos

Contingência

Dialética

Desempenho simples. Alguns aspectos: não determinístico, decomposição funcional limitada, distribuição da informação e autoorganização.

Foco na identificação e entendimento da estrutura organizacional em diferentes condições: várias formas de organização podem coexistir em diferentes condições.

Foco nas relações entre as organizações, conflitos e tensões, entendendo as parcerias como arranjos institucionais instáveis, com variações no sistema de governança.

Foco no processo de melhoria e desempenho das redes de cooperação

Fonte: Oliver e Ebers (1998); Bell et al. (2006); Camarinha-Matos e Abreu (2007); Carpinetti et al. (2008).

Bell et al. (2006) avaliaram a diversidade de teorias e disciplinas e o impacto das mesmas tanto na academia quanto para as empresas, entendendo que essa grande diversidade e falta de transversalidade prejudica a evolução do campo. Os autores consideram que existe a necessidade de um maior consenso quanto às teorias e uma maior relevância das pesquisas na prática organizacional. Isso facilitaria comparações, conexões e aplicações dos estudos na dinâmica dos processos de cooperação.

Pela necessidade de transversalidade e de um entendimento mais holístico das redes, a pesquisa teve enfoque central em teorias de estruturação e desempenho. Estas perspectivas trouxeram elementos para entendimento integral das redes e seu funcionamento, assim como contribuições mais adequadas para a estruturação de diretrizes de gestão das redes de PFNM.

Além da diversidade de conceitos e disciplinas que envolvem a cooperação 
interorganizacional, há uma diversidade de nomenclaturas e enfoques dos processos de cooperação no setor empresarial. Para Provan, Fish e Sydow (2007), Camarinha-Matos e Afsarmanesh (2008) e Parrilli e Sacchetti (2008) os diferentes processos de cooperação interorganizacionais ou interfirmas, como os aglomerados industriais (PORTER, 1998), arranjos produtivos locais ou sistemas produtivos e inovativos locais (CASSIOLATO; LASTRES, 2003), distritos industriais (SCHIMITZ;MUSYCK, 1994), redes de cooperação (AMATO NETO, 2000), redes colaborativas (CAMARINHA-MATOS; AFSARMANESH, 2008) e redes interorganizacionais (PROVAN; FISH; SYDOW, 2007) podem ser vistos e entendidos sobre a perspectiva de redes.

A Figura 8 apresenta o esquema estruturado por Camarinha-Matos e Afsarmanesh (2008), que busca demonstrar o desdobramento do conceito de redes colaborativas. Esse desdobramento contempla diferentes aspectos da cooperação interorganizacional, considerando redes orientadas por objetivos específicos, como as cadeias de suprimentos e as empresas virtuais, e redes de longo prazo, como algumas Organizações Virtuais e Clusters Industriais.

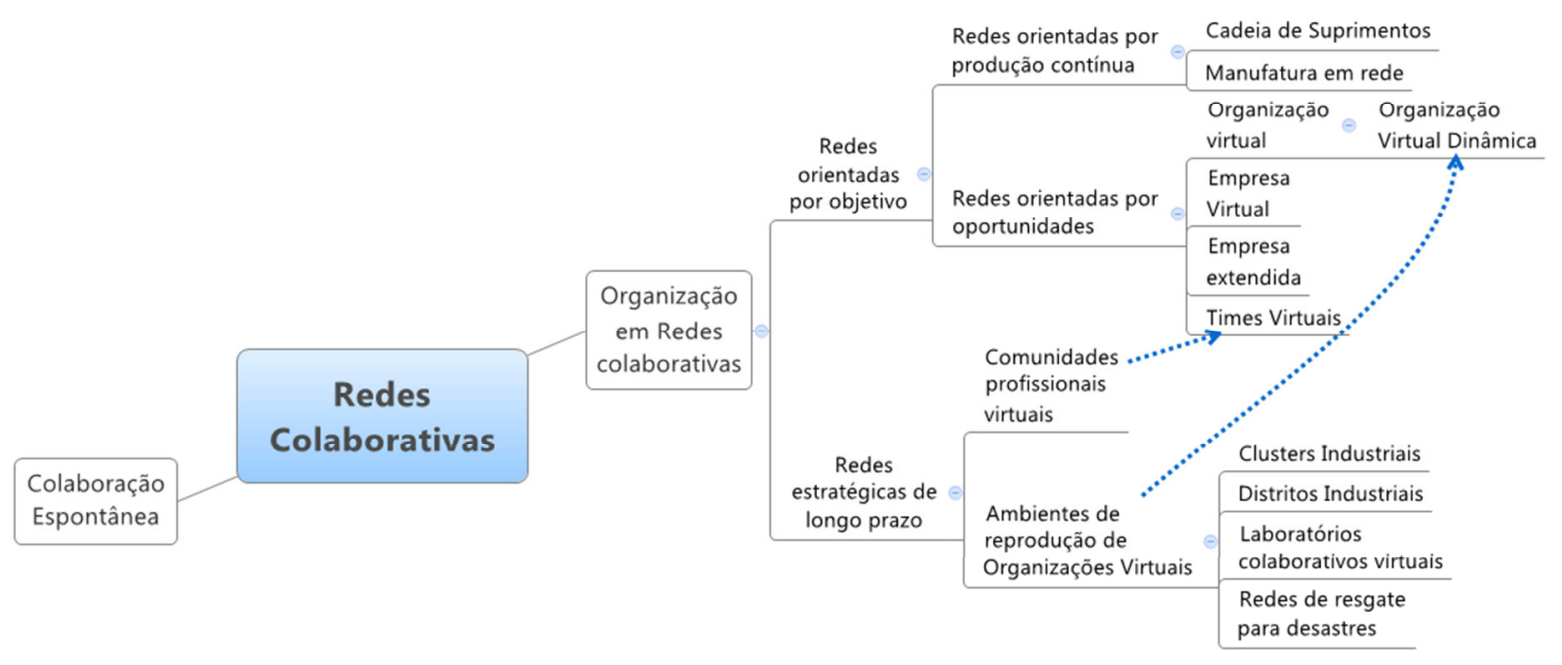

Figura 8: Redes Colaborativas.

Fonte: Adaptado de Camarinha-Matos e Afsarmanesh (2008, p. 2465).

Camarinha-Matos e Afsarmanesh (2008) descrevem as redescolaborativas como: 
[...] uma aliança constituída por diferentes entidades autônomas (e.g. organizações e pessoas), distribuídos geograficamente e heterogêneos quanto ao capital social, objetivos, ambiente de operação e cultura, mas que colaboram para alcançar objetivos comuns ou compatíveis, apoiados por redes computacionais (IBID, p. 2464).

Plisson et al. (2007) realiza a estruturação de conceitos, taxonomias e ontologias de redes. Para os autores as definições dessas ontologias são necessárias para a padronização e representação do conhecimento e para o entendimento mútuo entre pesquisadores e organizações, dividindo a mesma terminologia e conceitos.

Nesse sentido o Quadro 4 e $\circ$ Quadro 5 visam facilitar o entendimento ontológico e de caracterização das redes de cooperação. O Quadro 4 apresenta alguns pontos de entendimento e caracterização de redes encontradas na literatura consultada. O Quadro 5 apresenta uma ontologia das estruturas de gestão das redes de cooperação. 
Quadro 4: Pontos de caracterização e análise de redes de cooperação.

\section{Pontos de caracterização e análise da rede}

\begin{tabular}{ll}
\hline Tópico & Descrição \\
\hline $\begin{array}{l}\text { Governança e } \\
\text { coordenação da rede }\end{array}$ & $\begin{array}{l}\text { Foco em como a governança/gestão da rede ocorre entre os parceiros envolvidos, } \\
\text { buscando compreender a autonomia dos mesmos, os papéis de liderança, os ambientes } \\
\text { de comunicação e a concentração de recursos imateriais (conhecimento, poder, } \\
\text { informação, etc.), podendo ser analisado, segundo Provan, Fish e Sydow (2007) de três } \\
\text { formas dentro das redes interorganizacionais, como disposto nos itens seguintes: }\end{array}$
\end{tabular}

- Governança compartilhada (Simétrica)

- Governança pororganização líder (Assimétrica)
As organizações participantes trabalham coletivamente para planejar/realizar ações Provan, Fish estratégicas e operacionais, com pouca diferença de poder político e com tomada de Sydow (2007). decisão realizadas através de reuniões, encontros ou mesmo interações e colaborações informais.

Governança realizada por uma organização líder, onde as organizações podem ter Provan, Fish objetivos comuns, porém a gestão é realizada por uma organização mais forte Sydow (2007). politicamente, maior ou com posicionamento estratégico na cadeia.

- Agência de Gestão Organização criada especificamente para apoiar a gestão das ações conjuntas da rede.

Provan, Fish

Sydow (2007).

\section{Centralização}

Foco na posição do ator dentro de uma rede de relações em termos do número de laços Oliver e Ebers com outros atores. Provan acrescenta com: graus de centralidade, centralidade por (1998); Provan, Fish proximidade e centralidade "intermediária"/"betweeness". De que maneira uma ou e Sydow (2007). algumas organizações estão consideravelmente mais centralizadas do que outras? Redes mais descentralizadas são mais dispersas, com conexões espalhadas mais eventualmente entre os atores. 
Fragmentação

Capital Social

Eficiência Coletiva
Foco no entendimento da disposição da rede, se a mesma está mais conectada ou Provan, Fish fragmentada com poucas conexões, organizações isoladas ou dividida em subredes ou Sydow (2007). relações diádicas.

Características da organização social, como confiança, normas e sistemas, que Putnam (2000, p. contribuem para aumentar a eficiência da sociedade, facilitando as ações coordenadas. 177).

Foco na interação entre economias externas e ações coletivas entre os stakeholders, Schmitz (1995). promovendo iniciativas para melhorar a cooperação e competição.

Definições de regras, Foco na gestão e harmonização das instituições para viabilizar o trabalho cooperativo. Se Camarinha-Matos e papéis, instrumentos e considera a definição de papéis e tarefas, as regras de cooperação, assim como uma Afsarmanesh (2008); normas infraestrutura adequada.

Schuh e Wegehaupt (2004),

Recursos materiais

Foco em recursos materiais (e.g. dinheiro, ações, plantas, tecnologia, etc.).

Oliver (1998).

Recursos imateriais

Foco em recursos abstratos, não materiais (e. conhecimento, relações sociais, legitimidade, etc.).

Oliver (1998).

Foco na escassez ou generosidade de recursos.

Oliver e Ebers recursos

Especificidade de ativos

Dependência
Foco em ativos oportunidade.

Foco em uma situação onde, por qualquer motivo, uma parte é dependente de outra Oliver parte.
Oliver e Ebers (1998).

(1998). e Ebers 
Posição na rede

\section{Confiança}

\section{Oportunismo}

Estabilidade

Congruência de objetivos

Conflito

Densidade organizacional

Restrições de mercado

Nós

Laços Interorganizacionais
Foco na localização dos nós em um espaço multi-dimensional gerado por vários padrões Oliver de interação entre múltiplos atores.

(1998)

Foco na confiança que um ator transmite ao outro, ou mesmo que a rede transmite aos Oliver atores envolvidos.

(1998).

Foco na busca por interesses com "astúcia".

Oliver

(1998).

Foco no grau de mudança da natureza de um fenômeno (e.g. propriedades ou estruturas Oliver das organizações, ambiente ou relações da rede).

(1998).

Foco nos objetivos e interesses das várias partes que estão em harmonia, em acordo. Oliver

(1998).

Foco na ocorrência de interesses opostos ou falta de acordo e as disputas subsequentes. Oliver

(1998).

Foco no número de organizações (ou outras unidades) existentes sobre o domínio de Oliver uma organização, campo organizacional, ou área geográfica.

(1998)

Foco na imposição de demandas e/ou limitações do ambiente externo sobre as Oliver organizações. Isso pode incluir demandas legais/formais, limitação de recursos, (1998). competição, etc.

No foco das redes interorganizacionais os nós representam as organizações participantes Provan, Fish e da rede.

Sydow (2007); Oliver

e Ebers (1998).

Ligações e relações existentes entre os diferentes nós/organizações da rede.
Provan, Fish e Sydow (2007), Oliver e Ebers (1998). 
- Diádico

- Multiplo

- Horizontal

- Vertical

- Proprietário

- Contratual

- Político

Competitividade

Histórico/antecedentes de cooperação

Gestão da rede
Estudo dos laços entre duas partes apenas.

Estudo dos laços entre múltiplas partes.

Estudo dos laços entre atores engajados em atividades produtivas similares.

Estudo dos laços entre atores engajados em atividades produtivas próximas dentro da cadeia de valor.

Foco nos laços institucionalizados pela distribuição de direitos proprietários entre atores, onde um ator é proprietário dos recursos de um segundo ator (e.g. subsidiárias, joint ventures, franquias)

Foco nos laços institucionalizados pela distribuição de direitos proprietários entre atores, onde as relações entre dois ou mais atores são governadas por acordos contratuais os quais não remetem a propriedades conjuntas.

Foco nos laços que representam trocas de interesses políticos entre indivíduos, grupos ou Oliver entidades organizacionais.

Foco nos diferencias competitivos proporcionados pela organização em rede.

Foco nos antecedentes de cooperação e sua influência na estrutura e funcionamento da rede.

Foco na estruturação, gestão e funcionamento da rede como um todo.
(1998)

Porter (1998)

Oliver

(1998).

Ebers

Ebers

Oliver e Ebers

(1998).

Oliver

(1998).

Oliver e Ebers (1998).

Oliver

1998).

Ebers

Sövell et al. (2003; 2009).

Camarinha-Matos e Afsarmanesh (2008).

Fonte: Elaborado pelo autor. 
Quadro 5: Ontologia de estruturas de gestão de redes de cooperação.

\section{Estruturas de gestão}

\begin{tabular}{lll}
\hline Tópico & Descrição & Fonte \\
\hline Subredes & $\begin{array}{l}\text { Redes de colaboração que se formam dentro de uma estrutura de rede mais ampla (e.g. Provan, Fish e Sydow } \\
\text { empresa virtual dentro de uma organização virtual). }\end{array}$ \\
(2007).
\end{tabular}

Collaborative

Network

Organization (CNO)

É um conjunto de organizações que possuem o potencial e o desejo de colaborar para o Camarinha-Matos e estabelecimento de arranjos de cooperação, podendo ser estes arranjos dinâmicos ou de Afsarmanesh (2008); longo prazo.

Plisson et al. (2007).

Virtual Organization É um conjunto de organizações que possuem o potencial e o desejo de colaborar para o Camarinha-Matos e Breeding

Environment (VBE) estabelecimento de arranjos de cooperação de longo prazo, apresentando o ambiente Afsarmanesh (2008); adequado para o estabelecimento de acordos de cooperação, compartilhamento de infra- Plisson et al. (2007). estrutura, princípios e ontologias, confiança mútua, com o objetivo maior de aumentar o potencial de colaboração entre as organizações.

Organização Virtual A Organização Virtual é a cooperação entre organizações, instituições e/ou empresas, com Camarinha-Matos e (OV) uma divisão simétrica de poder, divisão clara de funções, papel e responsabilidades, para se Afsarmanesh (2008); atingir objetivos comuns ou compartilhados, tais como: a busca de novos negócios, Plisson et al. (2007). desenvolvimento de produto, solução de problemas, etc.

Empresa Virtual (EV)

A Empresa Virtual é a cooperação entre empresas, com uma divisão simétrica de poder, Camarinha-Matos e divisão clara de funções, papel e responsabilidades, para se atingir objetivos comuns ou Afsarmanesh (2008); compartilhados, tais como: a busca de novos negócios, desenvolvimento de produto, Plisson et al. (2007). solução de problemas, etc. A Empresa Virtual possui um direcionamento mais focado no negócio em si e pode se formar dentro de uma OV.

Broker

Papel a ser desempenhado por uma organização, focada ou não no mesmo, que busca a Camarinha-Matos e estruturação de novos negócios e empreendimentos coletivos que atendam aos objetivos e Afsarmanesh (2008); princípios comuns das organizações participantes/parceiras. 
Coordenador da OV Papel a ser desempenhado por uma organização, focada ou não no mesmo, que busca a Camarinha-Matos e coordenação do negócio compartilhado como um todo.

Afsarmanesh (2008);

Plisson et al. (2007).

Membros da OV

Instituições de

Suporte

\section{Agência de \\ Desenvolvimento \\ Regional (ADR)}

Organizações que fazem parte da OV, as quais possuem vontade e disponibilidade para a Camarinha-Matos e cooperação, dividindo princípios, valores e objetivos.

Afsarmanesh (2008);

Plisson et al. (2007).

Instituições participantes ou não da rede, cujo papel é de dar suporte técnico, tecnológico ou Camarinha-Matos e estrutural ao processo de cooperação (e.g. universidades, laboratórios, organizações de Afsarmanesh (2008); assistência técnica, etc.).

Plisson et al. (2007).

Agência representativa de uma rede colaborativa interorganizacional, que possui foco no Provan, Fish e Sydow apoio ao processo de cooperação, podendo concentrar diferentes funções da rede (broker, (2007). coordenador, administrador, marketing, etc.).

Fonte: Elaborado pelo autor. 
$\mathrm{Na}$ direção de estruturação de um modelo de referência para redes de cooperação, Camarinha-Matos e Afsarmanesh (2007, 2008) apresentam uma proposta de modelo denominado ARCON ( $A$ reference model for Collaborative Network). Essa proposta traz alguns pontos de relevância para a estruturação de redes, com enfoque especial em organizações virtuais e virtual organization breeding environment (VBE). O entendimento das redes é dividido em perspectivas internas (endógenas) e externas (exógenas).

A perspectiva endógena busca um olhar para dentro da rede, buscando estruturar e entender os processos de governança, estruturas organizacionais, os recursos e regras, sendo dividida em quatro dimensões:

- Dimensão Estrutural - participantes e suas relações, papéis, nós;

- Dimensão Componentes - elementos tangíveis e intangíveis: conhecimento, recursos(recursos físicos e intangíveis, recursos humanos, recursos de informação e conhecimento, recursos ontológicos), equipamentos, informação, elementos humanos;

- Dimensão Funcional - relativo à base de operações: processos, operações, workflow, planos, execução, metodologias;

- Dimensão Comportamental - princípios, políticas, e regras de governança: regras de conduta, valores, contratos, políticas de resolução de conflitos, comportamentos prescritos, comportamentos obrigatórios, restrições e condições, contratos e acordos de cooperação.

A perspectiva exógena também é dividida em quatro dimensões e busca 0 entendimento das relações com o mercado, instituições de suporte, sociedade e influência:

- Dimensão Mercado - relacionado com clientes e competidores;

- Dimensão Suporte - serviços de apoio realizadas por terceiros;

- Dimensão Sociedade - interação com a sociedade como um todo (empregos, capacitação, educação, sustentabilidade, etc.); 
- Dimensão Círculode influência - se refere ao círculo de outras organizações que podem fazer parte da rede e pode ser de interesse da rede atraí-las. (regras de adesão, marketing, fatores de atração).

Camarinha-Matos e Afsarmanesh $(2007,2008)$ identificam as fases do ciclo de vida das redes (Figura 9). O ciclo inicia com a criação da rede, com o princípio da colaboração, a busca de parceiros e a "fundação" da organização. Com a operacionalização da colaboração ocorrem ciclos de evolução e melhoria. A rede pode continuar seu processo de evolução ou entrar em um processo de metamorfose ou mesmo caminhar para a sua dissolução.

No caso de uma colaboração orientada por objetivo ou dinâmica pode ocorrer a dissolução da colaboração com o cumprimento do objetivo ou a metamorfose, buscando outro objetivo compartilhado. No caso de redes colaborativas de longo prazo o processo de metamorfose pode se confundir com o processo de evolução da rede. A dissolução ou declínio do processo de cooperação pode ocorrer, especialmente se os processos estagnarem e a cooperação fracassar.

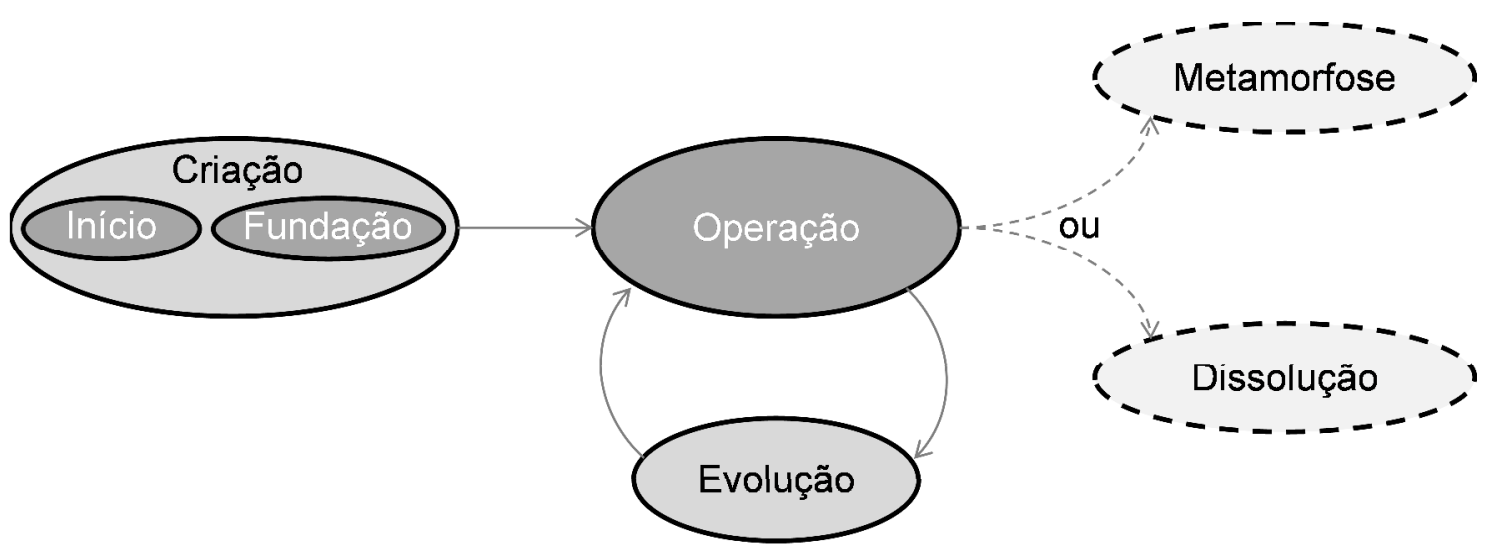

Figura 9: Fases do Ciclo de Vida de Redes Colaborativas.

Fonte: Adaptado de Camarinha-Matos e Afsarmanesh (2007, p. 539).

Uma perspectiva semelhante é apresentada por Sölvell et al. (2003) e Sölvell (2009), destacando a importância dos antecedentes e algumas fases de maturidade de melhoria dos clusters (Figura 10). Para os autores a dinâmica de funcionamento da cooperação interorganizacional demanda esforços organizados e uma 
infraestrutura compartilhada, que pode se organizar em facilitadores dedicados ou instituições para a colaboração, tais como associações e agências de desenvolvimento. Essa organização favorece a economia de escala e mesmo as melhorias de cooperação.

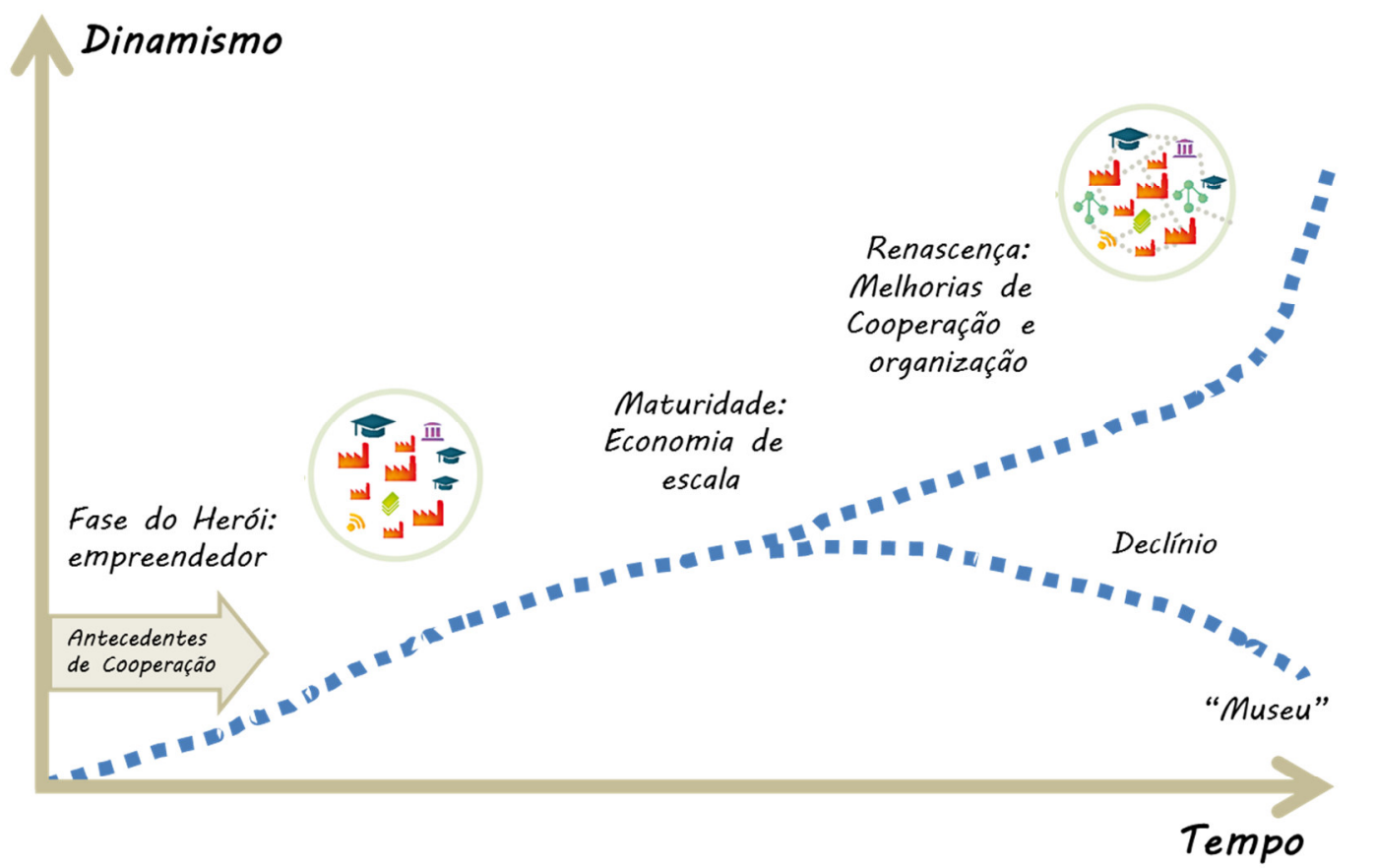

Figura 10: O ciclo de vida do cluster.

Fonte: Adaptado de Sölvell (2009, p. 53).

Com relação a redes estratégicas de longo prazo, como clusters industriais, Gerolamo (2007) e Carpinetti et al. (2008) apresentam algumas diretrizes para promover a gestão da melhoria e desempenho em redes de cooperação empresariais (Figura 11). As diretrizes se organizam em dois ciclos: um ciclo inicial de projeto da rede de cooperação e um ciclo contínuo de gestão e operação da rede de cooperação. As diretrizes estão organizadas em cinco passos demonstrados a seguir. 


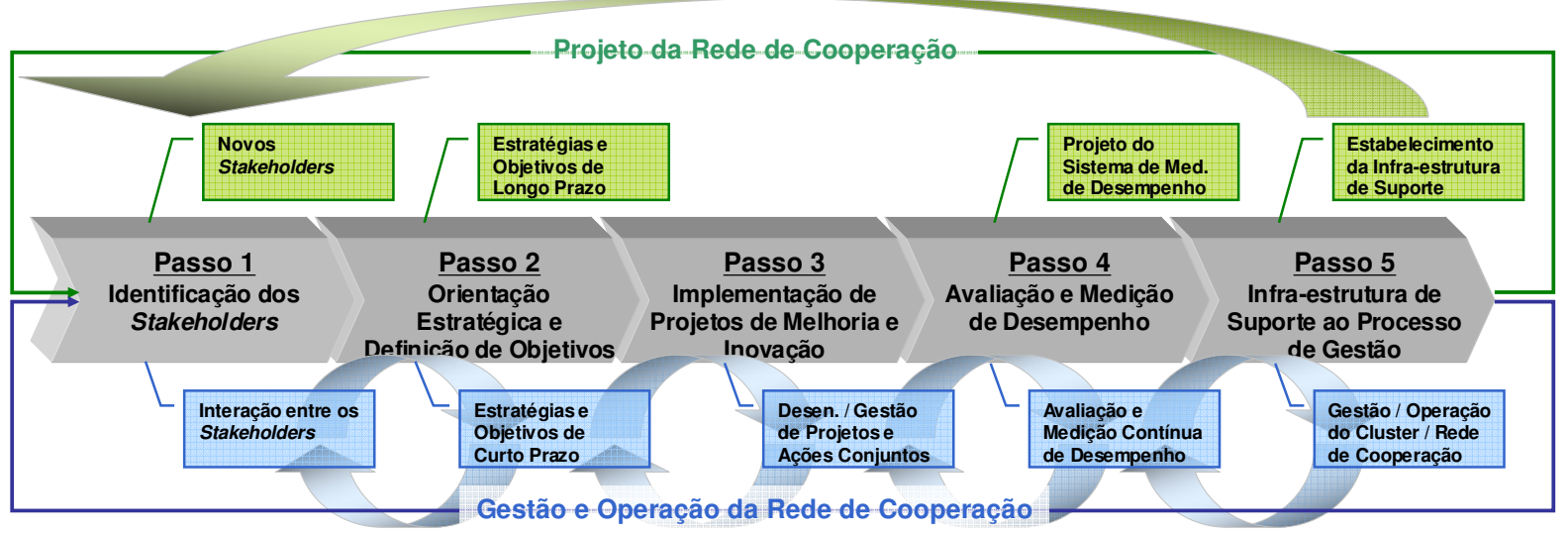

Figura 11: Gestão de desempenho de clusters industriais e redes de cooperação empresarial.

Fonte: Gerolamo (2007).

1. Identificação das necessidades e contribuições dos stakeholders do cluster: Identificação dos stakeholders, seus papéis, suas demandas, contribuições e expectativas quanto à rede de cooperação.

2. Elaboração do planejamento estratégico e definição de objetivos de desempenho do cluster: o planejamento estratégico da rede de cooperação é um mecanismo que pode ser utilizado para direcionar as estratégias sociais, ambientais e industriais para a região e deve envolver, além dos interesses locais das PMEs, as expectativas, necessidades e contribuições dos diferentes stakeholders.

3. Implantação de ações coletivas (joint actions) e projetos de cooperação empresarial para promover o processo de inovação contínua do cluster: Processo de implantação dos objetivos e ações compartilhadas. As ações desenvolvidas coletivamente buscam, além de melhorias de desempenho, aumentar a cooperação, o ganho coletivo e o capital social, trazendo, de acordo com o planejamento realizado, os resultados buscados para a região.

4. Avaliação e medição de desempenho do cluster:A medição de desempenho apoia o processo de melhoria continua do cluster e suas ações através de indicadores que tragam informações estratégicas para a gestão e tomada de decisão. 


\section{Construção de uma infraestrutura de suporte para a gestão de} desempenho do cluster: os autores consideram importante contar com o apoio de uma estrutura e infraestrutura compartilhadapara uma gestão eficiente da cooperação.

Schuh e Wegehaupt (2004) trazem uma análise de dez anos de funcionamento da Virtuelle Fabrik, com um olhar sobre a cooperação de mais longo prazo. A rede de colaboração da Virtuelle Fabrik se organiza através de uma instância focal de governança ou agência de cooperação, a qual promove a organização da rede e presta diferentes serviços para as empresas. Há uma busca pela autogestão da rede e dos projetos, a qual é melhor estruturada dentro dos projetos de cooperação em si.

A estrutura geral de gestão da cooperação na Virtuelle Fabrick é esquematizada pela Figura 12. A visão, valores, normas e missão da cooperação (item 5) fornecem o direcionador geral para a operacionalização da cooperação (item 3) e a definição estratégica compartilhada (item 4), definidos como "MetaSistema". A implementação da estratégia ocorre através da formação de parcerias interorganizacionais (itens 1) coordenados por um prestador de serviço de coordenação (item 2), que busca sincronizar as atividades individuais na execução do projeto/ação em direção à operacionalização da estratégia.

Os itens 2, 3, 4 e 5 da gestão da rede de cooperação na Virtuelle Fabrick são realizados por uma "Instância de Administração Focal". Esta apoia a cooperação através de serviços de: gestão geral da rede, auditoria, brokering, gestão da performance da rede e gestão de contratos. 


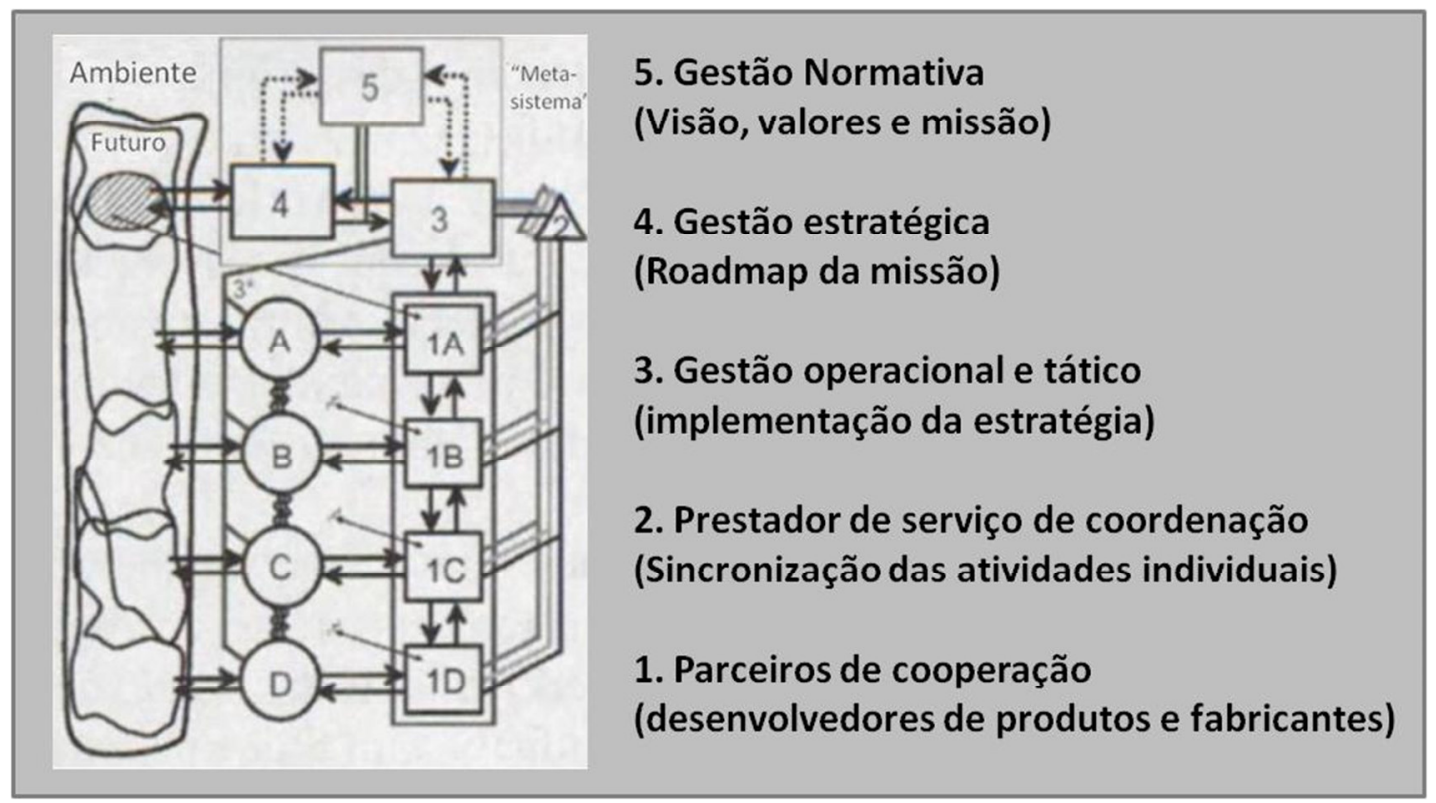

Figura 12: Gestão de redes cooperativas.

Fonte: Adaptado de Schuh e Wegehaupt (2004).

Schuh e Wegehaupt (2004), Camarinha-Matos e Afsarmanesh (2007; 2008) e Plisson et al. (2007) apontam a necessidade de se estruturar alguns papéis para o funcionamento das redes de colaboração ou para os ambientes de reprodução da colaboração. A definição e estruturação clara desses papéis facilita o processo de identificação de competências, de transparência, de comunicação entre os parceiros e realização de projetos coletivos, os quais são fundamentais para a se adquirir experiência e confiança na rede (SCHUH; WEGEHAUPT, 2004).

Para Schuh e Wegehaupt (2004) a visão de futuro compartilhada como ação inicial é fundamental para o processo de colaboração, destacando, também, alguns fatores de sucesso da Virtuelle Fabrick:

- Definição clara dos perfis dos parceiros antes da fundação da rede de competência;

- Flexibilidade e abertura para a saída e entrada de empresas parceiras;

- Capacidade dos parceiros para os negócios em sistemas - Cada empresa parceira possui a capacidade de executar atividades da construção até a entrega; 
- Vontade de comunicação e capacidade dos parceiros;

- Competência de estruturação de problemas dos parceiros e do Broker;

- Compreensão dos valores comuns (conhecimentos, motivação, compatibilidade de metas, regras);

- Integração da rede em função da organização das empresas estabelecidas;

- Criação de responsabilidades claras para atividades nas empresas parceiras, bem como no nível de rede;

- Recursos conjuntos e transparência de conhecimento;

- Identidade de sistema - Marca "Nós";

- Existência de uma cultura de conflito distinta;

- Conjunto de infraestrutura de Hard/Software.

Analisando a literatura consultada sobre as redes de cooperação observa-se que as dimensões endógenas e exógenas propostas por Camarinha-Matos e Afsarmanesh (2008) e as diretrizes de gestão de desempenho propostas por Gerolamo (2007) e Carpinetti et al. (2008) contemplam diferentes aspectos dos processos de cooperação em rede e podem contribuir de forma mais estruturada para a pesquisa. Além das diretrizes propostas por esses autores, destaca-se 0 entendimento da rede como um todo e sua caracterização, como proposto por Provan, Fish e Sydow (2007), considerando alguns fatores de análise, como: governança, centralidade e recursos.

\subsection{Considerações Finais}

Tanto a literatura sobre os PFNM quanto a literatura de redes de cooperação envolvem diferentes disciplinas e uma vasta quantidade de estudos e enfoques. Essa revisão bibliográfica não tem a pretensão de considerar todos os aspectos 
dessas áreas de estudo e nem esgotar essa literatura, mas busca, no entanto, o entendimento dos pontos centrais da gestão de redes de cooperação e dos processos de governança que envolvem as cadeias de PFNM.

Para entender a dinâmica de funcionamento das diferentes cadeias de PFNM a literatura consultada buscou observar as questões socioeconômicas e institucionais da Amazônia, a dinâmica de funcionamento do extrativismo, as cadeias de valor e relações com o mercado e stakeholders. Observa-se que os estudos consultados para as relações na cadeia e mercado possuem maior enfoque no entendimento dos impactos dessas cadeias nas populações tradicionais e floresta e nas relações entre os elos e funcionamento das cadeias de valor. No geral os estudos trazem aspectos a serem considerados na análise e monitoramento das cadeias e relações de parceria, e apontam para a necessidade de melhoria na relação entre populações tradicionais, mercado, instituições e governo.

Não foi observada a existência específica de estudos que contemplem redes de cooperação com enfoque em PFNM e seus aspectos de gestão e governança. No entanto, a literatura consultada sobre os PFNM pode contribuir para 0 entendimento de aspectos específicos da governança das cadeias e redes. Assim, da literatura destacam-se alguns pontos centrais a serem observados nos processos de gestão das redes:

i. Suporte em questões socioeconômicas e de gestão, especialmente: educação, comunicação, crédito e formação em gestão (MORSELLO, 2006; TE VELDE et al. 2006; POKORNY et al., 2012);

ii. As relações existentes na cadeia de valor (MARSHALL; NEWTON; SCHRECKENBERG, 2003, 2006; TE VELDE et al., 2006; JENSEN, 2009);

iii. O sistema de governança e capital social da região Amazônica (DE SARTRE; TARAVELLA, 2009; FEARNSIDE, 2003); 
iv. Estruturas transparentes de monitoramento de impacto e desempenho da cadeia e rede (MARSHALL; NEWTON; SCHRECKENBERG, 2003, 2006; TE VELDE et al., 2006);

A literatura que trata de sistemas, estruturas ou modelos de gestão de redes de cooperação traz algumas diretrizes norteadoras importantes para a gestão da colaboração interorganizacional. Sölvell (2009) e Camarinha-Matos e Afsarmanesh (2008) apontam o ciclo de vida das redes de cooperação o qual segue os seguintes passos: i) inicio e formação; ii) maturidade e operação; iii) evolução e melhoria contínua; iv) metamorfose, dissolução ou declínio.

O entendimento da fase em que a rede se encontra contribui para o entendimento da maturidade da mesma e o mapeamento das formas de ação necessárias para a melhoria do processo de cooperação. O entendimento da rede como um todo, como proposto por Provan, Fish e Sydow (2007) e dos antecedentes de cooperação trazem elementos de análise e compreensão sobre a governança, regras, acordos, confiança, ações conjuntas e outros elementos de organização das redes de cooperação.

De maneira geral, as redes de longo prazo para a realidade dos PFNM, envolvem extrativistas, instituições de apoio, universidade, empresas e governo. Dependendo da rede e das cadeias de valor a participação dos diferentes stakeholders podem acontecer de forma distinta, podendo ocorrer cooperações territoriais de longo prazo, sub-redes de cooperação específicas, desenvolvimento de produto, processos ou projetos, entre outros.

Dentro da literatura consultada para um entendimento mais abrangente $\mathrm{e}$ sistêmico da cooperação e seus processos de gestão Camarinha-Matos e Afsarmanesh (2007; 2008), Gerolamo (2007) e Carpinetti et al. (2008), trazem processos e diretrizes mais bem estruturados e complementares. Por esse motivo esses trabalhos são centrais na estruturação desta pesquisa.

Camarinha-Matos e Afsarmanesh (2008), através do ARCON, trazem uma 
maior quantidade de informações e detalhamentos na forma de se estruturar o processo de gestão de redes de cooperação, contemplando seu ciclo de vida, as diretrizes internas (dimensão endógena) e as diretrizes externas (dimensão exógena). De forma complementar Gerolamo (2007) e Carpinetti et al. (2008) apresentam um sistema de melhoria e desempenho, que contempla os diferentes stakeholders e um processo de planejamento, gestão e medição de desempenho de redes de cooperação.

Para compreender os processos de gestão envolvidos nas redes de PFNM é necessário contemplar como essas abordagens podem ser estruturadas dentro das formas de organização dessas redes. Assim, são considerados os seguintes pontos centrais de análise:

i. Caracterização da rede:

a. Histórico e antecedentes de cooperação (SÖLVELL et al., 2003);

b. Entendimento da rede como um todo, considerando: cadeias de valor, instituições, governança, articulação, coordenação e relações interorganizacionais, stakeholders, acordos, regras, contratos, princípios de cooperação e papéis (OLIVER; EBERS, 1998; PUTNAM, 2000; SCHUH; WEGEHAUPT, 2005; PROVAN; FISH; SYDOW, 2007;);

ii. Diretrizes de gestão e ciclo de vida da rede (GEROLAMO, 2007; CAMARINHA-MATOS; AFSARMANESH, 2008; CARPINETTI et al., 2008);

Pela literatura consultada, entende-se que a teoria de redes de cooperação possui contribuições quanto aos processos de gestão, apontando diretrizes, estruturas e procedimentos que viabilizam ambientes propícios à cooperação. Essas teorias podem servir de referência para análise dos processos existentes e posterior proposição de diretrizes de gestão de redes de longo prazo para as cadeias de PFNM. 


\section{Estudo de Caso - Rede Terra do Meio}

\subsection{Histórico da Rede Terra do Meio e Antecedentes de Cooperação}

A Rede Terra do Meio (RTM), primeiro denominada de Rede de Ação para a Terra do Meio, teve seu início em 2006 (VELÁSQUEZ et al., 2006), caracterizandose como um fórum de diálogo e um espaço político de negociação e planejamento do território. A rede deu continuidade à articulação entre as principais instituições responsáveis pela criação das Unidades de Conservação na região. As pautas centrais desse grupo de atores foram estruturadas em um plano de ação compartilhado que buscava a transparência nos processos operados pelo Ibama, a consolidação das Unidades de Conservação, a criação da Resex Rio Xingu e a garantia de acesso das Populações Tradicionais a direitos básicos.

Em 2007 foram criados os conselhos das Resex Riozinho do Anfrísio e Rio Iriri de forma integrada, visando o diálogo de aspectos comuns às áreas e a redução de custos de operação dos conselhos e da gestão do Instituto Chico Mendes de Biodiversidade (ICMBio) ${ }^{6}$. O plano de ação de 2006 continuou balizando as instituições em 2007 tendo a aproximação maior das associações, Ibama e do Ministério Público Federal (MPF).

As relações institucionais nos primeiros anos eram de cobrança e conflitos, principalmente com relação ao governo federal e municipal, envolvendo ações no MPF e Termos de Ajuste de Conduta (TAC) para que as obrigações do Estado fossem cumpridas.

${ }^{6}$ O ICMBio foi criado pela Lei $n^{\circ}$ 11.516,de 28 de Agosto de 2007. A organização passou a ser reponsável pela gestão e fiscalização das UCs, substituindo o Ibama esse papel. 
Em 2008 foi realizada a avaliação e reestruturação das linhas de ação. Alguns temas centrais faziam parte das discussões e do plano de ação para a Terra do meio entre 2006 e 2008, sendo: assistência básica (educação, saúde, documentação), estudos ecológicos, diagnóstico socioeconômico, demarcação / regularização fundiária, atividades de uso sustentável, infraestrutura, proteção das unidades e pesquisa científica.

Em 2008 surge o Grupo de Trabalho (GT) de Atividades Produtivas da RTM, organizando-se também as primeiras ações conjuntas entre as instituições com 0 projeto "Renascer da Seringa". O enfoque inicial das organizações locais eram os produtos prioritários para comercialização dialogados em 2007 com as Resex Riozinho do Anfrísio e Rio Iriri, a organização social e o mercado local com apoio à comercialização. Assim, foram realizadas articulações com comerciantes locais para borracha e castanha e foram implantadas algumas melhorias no beneficiamento da farinha e foi instalada a Oficina Cabocla ${ }^{7}$ no Riozinho do Anfrísio.

Em 2009, o quarto Encontro da Rede Terra do Meio discutiu a rede, seus objetivos, funcionamento e papéis. Nesse ano ocorreu a primeira aproximação da Fundação Nacional do Índio (Funai) ${ }^{8}$ e de representantes Indígenas das Tls da região.

A descrição e objetivo da Terra do Meio em 2009 são apresentados a seguir:

A Terra do Meio é um espaço de troca de experiências e de informações, com a função de aproximação de pessoas, instituições que atuam na região. O objetivo da rede é que haja comunicação sobre os

7 A Oficina Cabocla é uma estrutura simples de marcenaria destinada à confecção de pequenos móveis com temas regionais.

${ }^{8} \mathrm{~A}$ Funai é uma autarquia vinculada ao Ministério da Justiça. O objetivo da instituição é estabelecer e executar a Política Indigenista no Brasil, dando cumprimento ao que determina a Constituição de 1988. 
acontecimentos das diversas áreas protegidas da Terra do Meio e entorno, alinhamento de ações realizadas, planejamentos e consequente otimização de recursos humanos e financeiros aplicados na região (REDE TERRA DO MEIO, 2009)

Na reunião da RTM de 2009 foi levantada pela primeira vez a necessidade de uma estratégia compartilhada para a região, sendo proposta uma linha de ação denominada "Estratégias de extrativismo: Produção e comercialização" (REDE TERRA DO MEIO, 2009). Essa ação envolveu o Instituto de Pesquisa da Amazônia $\left(\operatorname{Ipam}^{9}\right)$, a World Wild Foudation $\left(W_{W} F^{10}\right)$, Fundação Viver, Produzir, Preservar $\left(F_{V P P}{ }^{11}\right.$ ), a Secretaria de Agricultura do Estado do Pará (Sagri) e o Instituto de Desenvolvimento Florestal do Pará $\left(\right.$ Ideflor $^{12}$ ) com responsabilidade e coordenação do Instituto Socioambiental $\left(\right.$ ISA $\left.^{13}\right)$ para sua execução. Nesse ano foram realizados

9 O Ipam é uma organização não-governamental e sem fins lucrativos voltada ao desenvolvimento sustentável da Amazônia.

10 A WWF é uma organização não governamental internacional comprometida com a conservação da natureza.

11 A FVPP é uma organização sem fins lucrativos, fundada para atuar como representante do movimento social organizado da região da transamazônica, que visa melhorar a qualidade de vida (educação, saúde e renda) das famílias instaladas na região.

${ }^{12} \mathrm{O}$ Ideflor é um entidade de direito público do estado do Pará, constituída sob a forma de autarquia, com autonomia técnica, administrativa e financeira (IDEFLOR, 2009). O principal objetivo do instituto é promover a produção sustentável de produtos florestais não madereiros e a gestão e concessões das florestas públicas estaduais

${ }^{13}$ O ISA é uma Organização da Sociedade Civil de Interesse Público (OSCIP), sem fins lucrativos, que realiza trabalhos voltados à proposição e desenvolvimento de soluções a questões sociais e ambientais de forma integrada. 
alguns estudos para subsidiar o planejamento proposto, entre eles o estudo sobre a viabilidade de estruturação de um APL de PFNM na Terra do Meio (COOPERAÇÃO TÉCNICA ALEMÃ,, 2009), o estudo de mercado para os diferentes produtos pelo Ibens (IBENS, 2009) e o estudo de potencial das oleaginosas na Resex do Rio Iriri (INSTITUTO SOCIOAMBIENTAL, 2010).

Em 2010, toda a rede passa a se organizar por GTs, aos moldes do GT de Produção e Comercialização, sendo estes divididos inicialmente em: GT de Atividades Produtivas, GT de Proteção e Regularização Fundiária, GT de Áreas Protegidas e GT de Políticas Públicas Sociais.

Essa estrutura não se modifica muito nos anos seguintes sendo as funções dos diferentes GTs discriminadas em 2012. O quadro a seguir descreve os diferentes GTs e suas funções.

Quadro 6: Funções dos GTs.

\begin{tabular}{|l|l|}
\hline GT Pesquisa & $\begin{array}{l}\text { Gestão do Banco de dados do acervo científico, promoção de } \\
\text { encontro de pesquisa, divulgação, identificar demandas de } \\
\text { pesquisa e lacunas de conhecimento, divulgação, periódico de } \\
\text { pesquisa, fomentar pesquisas na região. }\end{array}$ \\
\hline GT Atividades Produtivas & $\begin{array}{l}\text { Sistematizar informações produtivas, acompanhar atividades } \\
\text { produtivas em andamento, acompanhar implementação do } \\
\text { plano de ação de Produção e comercialização, divulgação }\end{array}$ \\
\hline GT Políticas Públicas Sociais - Saúde e & $\begin{array}{l}\text { Acompanhar politicas públicas sociais, sistematizar informações } \\
\text { sobre as politicas, acompanhar andamento das politicas, cobrar } \\
\text { a implementação de politicas das autoridades. }\end{array}$ \\
\hline participação de conselhos & $\begin{array}{l}\text { Implementação do ordenamento fundiário do Mosaico, Análise } \\
\text { estratégica de vetores de pressão, Acompanhamento de } \\
\text { processos em andamento, divulgação, proposição de estratégias } \\
\text { para anulação de ameaças potenciais e conflitos instaurados }\end{array}$ \\
\hline GT Consolidação Territorial e Proteção) & \\
\hline os documentos que subsidiama criação.
\end{tabular}

Fonte: REDE TERRA DO MEIO (2012) 
Cada GT tem dinâmica independente de funcionamento, sendo diferentes as formas de organização e atuação dos mesmos dentro da rede. A reunião anual da RTM passou a ser o momento em que as instituições e GTs dividem seus planejamentos, projetos e experiências na busca de maior complementariedade das ações no ano e no longo prazo.

Apesar da divisão de agendas, troca de informações e a definição geral de atividades prioritárias e linhas de ação as instituições são autônomas para se organizarem, elaborarem e executarem projetos. A cooperação interinstitucional ocorre de forma mais concentrada nas ações conjuntas que se desdobram dos planejamentos do GTs e das relações pessoais e institucionais.

A participação das instituições nas reuniões da RTM ao longo dos anos é apresentada no quadro a seguir.

Quadro 7: Participação das Instituições na Rede da Terra do Meio.

\section{Reunião Ano Participação das Instituições}

1‥ $2006 \quad$ FVPP, CPT, ISA, IPAM e ED

2․ $\quad 2007$ FVPP, ISA, ED, Ibama, MPF, Associações Comunitárias das Resex do Rio Iriri, Riozinho do Anfrísio e Comunitários da Região do Rio Xingu, atualmente, Resex do Rio Xingu.

3․ 2008 FVPP, ICMBio, Ibama, ISA, WWF-Brasil, LAET, GRET, ADAFAX, IPAM, ED, STTR Altamira, MPF, Associação de Moradores das Resex do Rio Iriri, Riozinho do Anfrísio, Xingu e Associação de Moradores da APA do Triunfo, Pesquisadores da Universidade de Florida e Universidade Federal do Acre.

4․ 2009 FVPP, ISA, EDF, Ibama, ICMBio, MPF, SEMA/PA, SAMAT/ATM, SAMATUR / São Felix do Xingu, ADAFAX, SEMAT/ATM, FUNAI Altamira, WWF-Brasil, IDEFLOR, TNT, TNC, LAET, Associação de Moradores das Resex do Rio Iriri, Riozinho do Anfrísio, Xingu, Estrada Canopus, TI Xypaya / Aldeia Tukamã, Universidade de Indiana, IPAM/UFPA, USP.

52010 EDF, EMATER, FUNAI, FVPP, GTZ, ICMBio, IDEFLOR, Imaflora, INCRA, IPAM, ISA, AERIM MMA/ARPA, MPF, RESEX Xingu, Riozinho do Anfrísio, SAGRI, SEMA-PA, SEMAT, SEMEC, SENAR, SESPA, SEMSA, UFPA, UFPA-LAET, USP, WWF.

62011 FUNAI, FVPP, GIZ, ICMBio, IDEFLOR, Imaflora, INCRA, IPAM, ISA, RESEX XINGU, RESEX RIO IRIRI, RESEX RIOZINHO DO ANFRÍSIO, SAGRI, SEMAT, SEMSA, UFPA, UFPA-LAET, UFPA-CNX, USP, WWF, ADAFAX, 
TNC, IFT, MOVIMENTO DE MULHERES (MMXT)

7

2012 FVPP, AFP, WWF, SEMAT, SEBRAE, EDF, FUNAI, UFPA, IPAM, ISA, USP, TV CULTURA, ICMBio, INSTITUTO KABUL, IDEFLOR, OPAN, ANSA, IFT, MEC, Imaflora, DPEPA, TNC, EMATER, SEMA, SOCIARTE, ATIX e UNIVERSIDADE DE HAMBURGO.

Fonte: INSTITUTO SOCIOAMBIENTAL $(2006,2007)$, REDE TERRA DO MEIO $(2008,2009,2010$, 2011, 2012).

Pelo enfoque do trabalho nos processos de cooperação envolvendo as cadeias de valor, o GT de Atividades Produtivas será detalhado nos itens da pesquisa com o entendimento dos processos de planejamento, funcionamento e das diferentes ações nas cadeias de PFNM da Terra do Meio.

\subsection{O GT de atividades produtivas e o processo de planejamento das cadeias de valor da Terra do Meio}

O GT de atividades produtivas iniciou-se em 2008 com a participação das principais instituições interessadas na promoção das cadeias de valor da Terra do Meio, como: ISA, Ipam, WWF e ICMBio. Uma das primeiras ações conjuntas do grupo foi o projeto "Renascer da Seringa", o qual viabilizou intercâmbios, a contratação de um técnico de campo e o processo de retomada dos seringais.

Uma das avaliações realizadas em 2008 na reunião da RTM foi a necessidade de uma orientação estratégica para o desenvolvimento das cadeias da Terra do Meio. Assim, foi contratato pelo ISA em 2009 um estudo de mercado (IBENS, 2009), o qual trouxe subsídios para o entendimento dos mercados e cadeias regionais. Em paralelo foi realizado pela Cooperação Técnica Alemã (GTZ) um estudo de arranjos produtivos locais de produtos florestais não madeireiros (COOPERAÇÃO TÉCNICA ALEMÃ, 2009), que teve como objetivo o estudo das principais cadeias de valor e entendimento da viabilidade de organização de um APL no território. 
Esses estudos, em conjunto com os diagnósticos socioeconômicos de 2007 (INSTITUTO BRASILEIRO DE MEIO AMBIENTE E RECURSOS NATURAIS, 2007a, 2007b), os Planos de Manejo das Resex de 2010 (INSTITUTO CHICO MENDES DE CONSERVAÇÃO DA BIODIVERSIDADE, 2010a, 2010b), os estudos de custo de produção realizados pelo Imaflora entre 2009 e 2010 (INSTITUTO DE MANEJO E CERTIFICAÇÃO FLORESTAL E AGRÍCULA, 2010a, 2010b, 2010c) e o conhecimento institucional acumulado, formaram a base para o processo de planejamento estratégico das cadeias de valor de PFNM da Terra do Meio, iniciado no segundo semestre de 2010 .

O planejamento buscou envolver, em um primeiro momento, as organizações que já atuavam na região, representantes extrativistas e algumas empresas com relações mais próximas das organizações e cadeias. Não foram chamados operadores locais das cadeias com os quais não havia relação de confiança, sendo essa aproximação realizada em momentos mais diretamente ligados aos estudos e melhorias das cadeias.

O processo de planejamento foi coordenado pelo Imaflora e pelo ISA, os quais mobilizaram as instituições locais e pessoas envolvidas com a Terra do Meio. O Imaflora aproximou-se da Terra do Meio em 2009 tendo como enfoque a conexão das comunidades extrativistas com o mercado de forma mais ética e o apoio na realização do plano estratégico regional.

O processo de planejamento conjunto foi estimulado pelos estudos anteriores, que indicavam a necessidade de uma melhor orientação e coordenação interinstitucional, buscando reduzir a replicação de trabalho, retrabalhos e ações parciais e melhorar a coordenação interinstitucional e o monitoramento das ações. A vinda de uma instituição neutra e de confiança ao contexto regional foi entendida como necessária para facilitar o processo de planejamento e cooperação.

Os dois primeiros ciclos de planejamento contaram com a participação intensa das instituições e representantes das Resex. Isso permitiu a realização de análises 
de conjuntura das cadeias e a proposição de estratégias e ações de médio e longo prazo. Percebeu-se no processo de planejamento que o entendimento das cadeias, seus gargalos e possibilidades não estavam nivelados entre organizações participantes.

Nos processos de mapeamento e análise houve divergências sobre as cadeias prioritárias, sobre o papel das instituições e sobre o entendimento da dinâmica das comunidades. Isso resultou na estruturação de princípios norteadores dos trabalhos das instituições na região, sendo estes:

1. Diversidade de produtos com volumes pequenos como característica do sistema de produção, do modo de vida tradicional e da estratégia de sobrevivência;

2. Respeito ao calendário produtivo dos povos da floresta;

3. Sazonalidade e variação de produção como características da dinâmica florestal;

4. Valorização dos aspectos culturais, da dinâmica social e econômica local;

5. Compreender as perspectivas e anseios locais relacionadas à manutenção ou introdução de inovações nas práticas produtivas;

6. Respeito à diversidade cultural regional (extrativistas, ribeirinhos, indígenas, colonos);

7. Integração do conhecimento tradicional ao desenvolvimento de processos, padrões, formações e pesquisas;

8. Priorização das atividades tradicionalmente trabalhadas antes de se pensar na introdução de novas atividades econômicas;

9. Respeito ao tempo de maturação das ações, com a continuidade das propostas e projetos de pelo menos 3 anos (planejamento, investimentos, formação, implementação, acompanhamento e consolidação);

10. Construção de relações comerciais que se adequem às características e dinâmicas locais, com alinhamento de princípios e valores;

11. Realização de melhorias na produção, escoamento e comercialização em conjunto com 0 avanço das relações com o mercado e suas demandas. (REDE TERRA DO MEIO, 2011b).

O alinhamento quanto aos princípios de trabalho foi importante para aumentar 
a clareza sobre a direção a ser seguida, melhorando o diálogo, o entendimento sobre as áreas protegidas e o escopo do planejamento estratégico.

Como resultado o planejamento conseguiu apontar diferentes gargalos, linhas estratégicas e ações a serem realizas para promover as cadeias de PFNM na região. As desconexões e ações propostas compuseram, em conjunto com as informações levantadas sobre a região, a primeira versão do Plano de Ação do GT de Produção e Comercialização da Rede Terra do Meio.

Dentro do processo de planejamento estava previsto o dialogo e entendimento do funcionamento do GT e dos papéis institucionais. Porém, em 2011 houve o licenciamento para a construção da Usina Hidrelétrica (UHE) de Belo Monte (Barrionuevo, 2011) e se estruturou um novo fórum político para planejar o desenvolvimento regional, o Plano de Desenvolvimento Sustentável Regional do Xingu (PDRS Xingu). O PDRS Xingu é um instrumento para a descentralização de políticas públicas que busca a realização de planejamentos territoriais participativos para o desnvolvimento regional, sob coordenação de um Grupo de Trabalho Intergovernamental envolvendo instituições do Governo Federal e do Governo do Estado do Pará (PDRSX, s/d).

Com Belo Monte e o PDRS Xingu o tempo institucional para reuniões e planos dentro do GT diminuiu, ao contrário do aumento de protestos, mobilizações e reuniões. Isto levou a uma redução da participação institucional em reuniões e promoveu, simultaneamente, a necessidade de detalhar o plano para utilização no PDRS Xingu.

Um impacto importante causado por este excesso de reuniões foi o desgaste das relações pessoais e interinstitucionais. $O$ excesso de encontro das mesmas pessoas, em reuniões diversas e com pouco alinhamento nos temas dialogados fez com que as diferenças sobrepusessem os entendimentos comuns, dificultando o diálogo.

Outro aspecto a ser destacado no funcionamento institucional regional é a 
constante mudança de pessoas nas instituições, especialmente governamentais, que gera uma descontinuidade de entendimento de processo. Para exemplificar, entre 2006 e 2014 a equipe do ICMBio foi modificada totalmente quatro vezes.

Nesse processo a definição do funcionamento do GT e o papel das instituições ficaram em segundo plano. Com a menor participação institucional o processo de detalhamento do plano foi prejudicado, trazendo desconexões de entendimento do mesmo. Como forma de superar esse déficit foram realizadas visitas específicas do Imaflora às instituições em 2012 para apresentar o plano e buscar complementações.

Em Abril de 2013, já com a dinâmica do PDRS Xingu e da UHE Belo Monte mais absorvida pelas instituições, foi realizado o resgate do histórico de cooperação do GT, das ações nas principais cadeias de valor e o plano de ação. Esse processo apresentou resultados positivos no engajamento das instituições, com um novo alinhamento com relação às diretrizes e ações previstas. Em 2013 foi possível começar o monitoramento do plano de ação, determinar o funcionamento do GT e o entendimento dos papéis institucionais.

A implantação das ações planejadas passaram a ocorrer através de subdivisões autônomas das instituições do GT, em grupos menores. Nesse processo as instituições ora exercem papel ativo na implantação ora exercem papel de apoio e monitoramento, voltando informações, avaliações e replanejamentos ao GT em suas reuniões ordinárias.

De maneira geral as instituições se dividiram, principalmente, nas seguintes linhas de ação em 2013:

- Políticas públicas para produtos extrativistas - ICMBio, Funai, ISA e Imaflora: desenvolvimento de ações direcionadas ao acesso aos mercados institucionais, especialmente o PNAE e o PAA Doação Simultânea, buscando relação comercial com prefeituras e instituições; 
- Cadeia de pequenos móveis e artesanato - ICMBio e Ipam: ação de desenvolvimento de uma nova cadeia reginal de fabricação de pequenos móveis através das Oficinas Caboclas já implantadas na parceria ICMBio e Ipam em unidades de conservação do rio Tapajós;

- Linhas de crédito alternativas - ISA e Imaflora: ações de desenvolvimento de linhas de crédito para viabilizar a operacionalização da cadeia pelos extrativistas das Resex;

- Ações de melhoria e operação para a cadeia da Borracha, Castanha e Copaíba - ISA e FVPP: ações de assistência técnica, suporte, apoio logístico, reabertura de áreas e operação de algumas atividades para viabilizar a melhoria da cadeia;

- Ações de melhoria nas mini-usinas de PFNM e cadeia de óleos vegetais ISA: estudo e estruturação de métodos de beneficiamento de múltiplos produtos em um mesmo espaços físico;

- Ações de desenvolvimento de Mercados - Imaflora e ISA: estudos de mercado, ações de relação com o mercado e desenvolvimento e implantação de ferramentas de valorização das cadeias de PFNM.

Vale um destaque com relação às ações de mercado realizadas pelo ISA e pelo Imaflora. Essas ações permitem o melhor entendimento do mercado e demandam uma ampla rede de relações para o sucesso das iniciativas, tanto para o desenvolvimento de mercado quanto para o desenvolvimento de ferramentas. Nesse sentido são destacadas as princiais ferramentas em desenvolvimento e as parcerias organizadas até 2014:

- Ferramenta para o levantamento de custos - processo que facilite o entendimento dos custos de produção e viabilizem processos de negociação com o mercado. Em desenvolvimento pelo ISA e Imaflora;

- Termos de Cooperação simplificados - construção de termos para as parcerias comerciais entre comunidades, instituições de apoio e empresas que respeitem os processos comunitários e suas 
características, evitando o excesso de linguagem e exigências jurídicas, com previsão de aumento gradual de volumes e processos de renegociação. Resultado da parceria comunidades, ISA, Imaflora, FVPP, ICMBio, Mercur e Firmenich;

- Portfólio de produtos - ferramenta que disponibiliza de forma gráfica os principais produtos, suas características e potencial. Essa ferramenta está cada vez mais agregada aos Protocolos Bioculturais;

- Protocolo Biocultural - é um documento construído em conjunto com as comunidades com o objetivo de comunicar para potenciais parceiros informações socioeconomicas regionais, a estrutura de governança do território, suas parcerias, informações dos produtos disponíveis, potenciais históricos e os requisitos da comunidade para estruturação de relações comerciais. A forma de construção desses protocolos está sendo desenvolvido com base na parceria Imaflora, ISA e a instituição internacional União para Biocomércio Ético (UEBT), que tem como enfoque os produtos da biodiversidade e objetivo a promoção de relações éticas de comércio, com repartição de benefícios.

- O Selo de Origem do Xingu - é uma iniciativa com enfoque inicial para a Terra do Meio e que se expandiu para atender as diferentes áreas protegidas do Xingu. Essa ação visa a estruturação de um processo de certificação de origem simples, que valorize a organização social existente e o patrimônio sociocultural e ambiental das diferentes áreas protegidas da região. O desenvolvimento desse sistema é coordenado pelo Imaflora e conta com a cooperação de algumas instituições, sendo: as empresas Safe Trace, Lodducca e Source Maps; e as instituições ISA, Associação Floresta Protegida (AFP), Amora, UEBT e a Associação Terra Indígena do Xingu (ATIX).

Olhando as linhas de ação desenvolvidas em 2013 no GT, percebe-se que o ISA, o Imaflora, o ICMBio e a Funai ficaram como os principais atores na implantação das ações em conjunto com as comunidades. Isso ocorre, 
principalmente, pelo fato da Funai e do ICMBio serem os gestores públicos das áreas protegidas e o ISA e Imaflora terem como enfoque principal de ação as Reservas Extrativistas. As demais instituições possuem atuação com maior enfoque na agricultura familiar, na pesquisa e na articulação política regional. Porém, as mesmas exercem o papel de monitoramento, de complementação e apoio às ações, especialmente em outros espaços políticos regionais. A FVPP em 2013/2014 diminuiu sua atuação em campo nas cadeias de valor de PFNM, sendo que mesmo nos demais anos sua participação foi restrita à Resex Rio Xingu, dado o seu enfoque histórico nos agricultores da Transamazônica e em ações na articulação política regional.

As principais iniciativas de melhoria das cadeias de valor de PFNMs e apoio técnico continuo às comunidades se concentraram no ISA para as unidades de conservação e na Funai para a terra indígena, em cooperação com as respectivas associações comunitárias e o ICMBio. O Imaflora é responsável por ações específicas da cadeia, especialmente no acesso ao mercado, apoiando as partes interessadas com informações, estudos e conexão comunidade-empresa.

Por limitações da Funai, pelo alto envolvimento dos indígenas com a UHE Belo Monte e pela falta de instituições que trabalhem diretamente com as Terras Indígenas, a maior parte das ações realizadas até 2013 nas cadeias de valor regionais aconteceu nas Resex. As ações da Funai ficaram restritas à participação no grupo de trabalho de políticas públicas e na estruturação de um projeto para a cadeia da castanha e merenda escolarpara a TI Xipaya dentro do PDRS Xingu entre 2013 e 2014.

Tornou-se também responsabilidade da Funai o acompanhamento do Plano Básico Ambiental (PBA) Indígena, que visa compensar os prejuízos causados pela UHE Belo Monte. O PBA Indígena possui diferentes áreas de atuação, sendo que os processos de produção constituem apenas uma dessas áreas. Com início em 2013 - PBA voltado para as atividades produtivas realizou ações praticamente independentes da Funai e não dialogou com o planejamento realizado até o 
momento na Terra do Meio.

Em 2012 foi feito um chamado ao ISA pelo MMA para apresentação de um projeto dentro do escopo do PNPSB. Essa proposta colocaria o ISA como instituição mobilizadora de um APL de produtos da sociobiodiversidade para a região Oeste do Pará. Pelo fato de não haver uma dinâmica logística e de relação entre o território da Terra do Meio e o restante do Oeste Paraense a proposta original foi negociada restringindo-se à Terra do Meio. Porém, o escopo do trabalho não pode ser negociado tendo o projeto o mesmo padrão para os outros oito territórios que foram contemplados pelo mesmo. O financiamento e suas atividades tiveram início somente no segundo semestre de 2013 e apoiaram a execução do processo de planejamento territorial já em andamento, mas não agregou em novos processos de articulação estadual e nacional como era esperado pela proposta construída pelo governo desde 2008.

Em 2014, além da reunião do GT, foi realizada a Semana do Extrativismo na Resex Rio Xingu. Um dos objetivos centrais do encontro foi possibilitar processos de diálogo entre os extrativistas e entre eles e as instituições e empresas, de forma a possibilitar uma participação mais ativa da comunidade no processo de avaliação e planejamento das cadeias de valor. A participação da comunidade ocorreu ao longo de todo o processo de planejamento, porém nunca de forma estruturada, com variação constante das pessoas da comunidade envolvidas, dificultando 0 entendimento das mesmas no processo.

Um processo complementar de avaliação e planejamento foi realizado no Curso de Gestão Territorial da Terra do Meio em 2014. Esse curso, iniciado em 2010 e promovido pela cooperação entre ISA e FVPP, está formando os comunitários das Resex no entendimento de seus direitos e em processos de gestão de seus territórios.

Assim, após todo o processo de planejamento apresentado podem-se destacar as seguintes linhas estratégicas do grupo de trabalho de produção e 
comercialização da Rede Terra do Meio:

Linha Estratégica Geral: partir do conhecimento tradicional, do uso múltiplo de produtos, do entendimento da demanda dos mercados (local, regional, institucional e diferenciado) e da articulação interinstitucional para a realização da melhoria na cadeia de valor, buscando a autonomia dos extrativistas de forma processual, através da prática e possibilidade de experimentação de tecnologias adequadas/adaptadas, da relação com 0 mercado, da formação continuada e acompanhamento técnico qualificado.

Estratégia de Mercado: A estratégia de mercado para os produtos da Terra do Meio deriva da estratégia de vida adotada pelas populações tradicionais, vinculada a Multi-produtos e baixo volume, com disponibilidade limitada pela capacidade florestal e pela quantidade de famílias envolvidas nas cadeias. Essa estratégia forma uma cesta de produtos extrativistas que poderão ter características diferentes, sendo as principais: mercados diferenciados, mercados institucionais (especialmente merenda regionalizada), mercado local e mercado interno. As demandas dos diferentes mercados e o conhecimento tradicional irão balizar as melhorias necessárias nas cadeias de valor.

Objetivo específico:

- Estruturar sistema de relação comunidade / empresas que se adeque às demandas de mercado e à realidade socioambiental das comunidades e valorize os produtos não madeireiros;

Estratégia de Formacão e Assistência Técnica: A formação dos extrativistas e a melhoria da assistência técnica ocorrem de forma conjunta para a melhoria das cadeias de valor dos não madeireiros na terra do meio. O enfoque estratégico para a região se encontra no aumento da assistência técnica para os não madeireiros, a formação em rede dos técnicos das diferentes instituições e a transferência da responsabilidade da assistência técnica para o estado. Essa assistência técnica deve ser vinculada e tomar como ponto de partida às práticas das populações tradicionais e a utilização de multiplicadores locais de boas práticas.

Objetivos específicos:

- Divulgar e expandir ações de melhoria entre os extrativistas nas diferentes cadeias, com: aumento da quantidade de famílias envolvidas e adoção de boas práticas;

- Melhorar conhecimento técnico de extensionistas, técnicos e extrativistas em PFNM na região;

- Fortalecer as organizações comunitárias formais;

Estratégia de tecnologia, agregacão de valor e qualidade: as melhorias nos processos de gestão, extrativismos, beneficiamento têm como orientação estratégica a escolha de produtos e processos já 
desenvolvidos pelas populações tradicionais, com a possibilidade de experimentação de tecnologias (gestão, beneficiamento, extração, etc.) através de intercâmbios e de um centro de tecnologias, que facilitará a escolha das comunidades nos processos a serem adotados pelas mesmas. Os processos/projetos de melhoria deverão estar ligados a contratos e negociações com o mercado. A base do desenvolvimento tecnológico é o conhecimento tradicional, a diversidade de produtos e a contemplação de processos de baixa e média escala.

Objetivos específicos:

- Melhorar a gestão dos projetos comunitários e familiares para as diferentes cadeias e grupos;

- Buscar e avaliar tecnologias adequadas (equipamentos, gestão, processamento e logísitica) para o manejo e beneficiamento dos produtos das diferentes cadeias, visando agregação de valor na produção, a disponibilização e divulgação de tecnologias apropriadas para as unidades comunitárias e familiares;

Estratégia de Crédito: Construir uma proposta de micro-crédito ou fundo rotativo regional adequado para as diferentes cadeias e grupos.

Estratégia de logística: partir da logística existente atualmente tanto para produtos de alto volume quanto para os de baixo volume. Para os produtos de alto volume a estratégia será a melhora da relação com os operadores logísticos (regatões e atravessadores) e estruturação de linhas de crédito alternativas. Para produtos de baixo volume o direcionamento logístico se encontra na melhoria da organização comunitária para coordenação de transporte (tanto com barcos próprios, quanto com os barcos comunitários e operadores logísticos locais);

Estratégia para Políticas Públicas: Desenvolver competência e experiências práticas na introdução dos produtos regionais dentro das diferentes políticas públicas existentes (PAA, PNAE, PGPM, etc.). Buscar, com base nessas experiências, adaptações/melhorias e influenciar no desenvolvimento de políticas públicas mais adequadas à realidade local.

Estratégia de Gestão de Áreas Protegidas: acompanhar, melhorar e implantar planos de gestão das diferentes áreas protegidas da Terra do Meio.

Estratégia Interinstitucional: melhorar coordenação, comunicação e transparência entre as instituições locais envolvidas com PFNM através do: desenvolvimento de bases de materiais comum, do desenvolvimento de ferramentas conjuntas de monitoramento e na execução e acompanhamento do plano estratégico.

Objetivos específicos: 
- Melhorar articulação, coordenação, troca de informações e gestão dos diferentes atores envolvidos com os processos de produção e comercialização de PFNM na Terra do Meio.

- Monitorar as ações, projetos conjuntos e impactos das cadeias de valor nas comunidades; (REDE TERRA DO MEIO, 2011b, p 31-33).

As ações institucionais e os principais resultados nas cadeias de valor são apresentados no item 3.3 - Produtos e Cadeias de Valor.

\subsection{Produtos e Cadeias de Valor}

\subsubsection{Introdução e contextualização das cadeias e ações regionais}

Como em outras regiões da Amazônia, as atividades econômicas da Terra do Meio, especialmente nas Resex, possuem uma forte relação com o sistema do seringal. O primeiro grande momento econômico regional foram os seringais implantados ao longo dos rios da região, possuindo o seringalista um papel central em todo o processo. Os seringueiros eram alocados em colocações de seringa pelos patrões e recebiam as condições iniciais necessárias para começar a trabalhar, que se resumiam basicamente a estradas, moradia e insumos de produção.

Os processos de comercialização eram centrados nos barracões colocados estrategicamente ao longo dos rios, os quais eram supridos de mercadorias e recebiam a seringa e a castanha para a comercialização. O seringueiro pegava do barracão os insumos e mercadorias que julgava necessários para seu trabalho e sustento e posteriormente pagava sua dívida com a borracha, podendo ou não ter um saldo positivo no final.

Com o declínio da borracha houve um esvaziamento do seringal e outros 
atores passaram a desenvolver o comércio local. Esse comércio passou a se concentrar na mão de pessoas de fora ou de dentro da região denominadas regatões, que dominavam a navegação e passaram a negociar os produtos locais.

Vale destacar o funcionamento do principal sistema de crédito que envolve a comercialização dos PFNM até o momento da pesquisa. Os regatões são financiados pelos comerciantes de Altamira interessados em alguns itens, como castanha, ouro, óleo, peixe e outros produtos regionais. Esses comerciantes, por sua vez, são muitas vezes financiados por empresas e compradores externos interessados nos produtos regionais. Esse ciclo de financiamento chega finalmente aos extrativistas, os quais constantemente compram com 0 regatão antecipadamente insumos, alimentos, equipamentos e utensílios domésticos necessários para a safra ou para a vida na localidade.

Os juros observados na cadeia da castanha com um dos comerciantes em Altamira chegava a ser de até $10 \%$ ao mês sobre o valor de empréstimo dos regatões. Já os custos desses juros, os custos da viagem (aproximadamente $550 \mathrm{~km}$ de rio até a cidade) e os riscos de naufrágio e calote assumidos pelo regatão acabam refletindo na diferença de valor entre os produtos comercializados na cidade de Altamira e os produtos comercializados nas Resex.

A Figura 13 toma a cadeia da castanha como exemplo para ilustrar 0 funcionamento das diferentes cadeias de valor de PFNM na região de Altamira. 


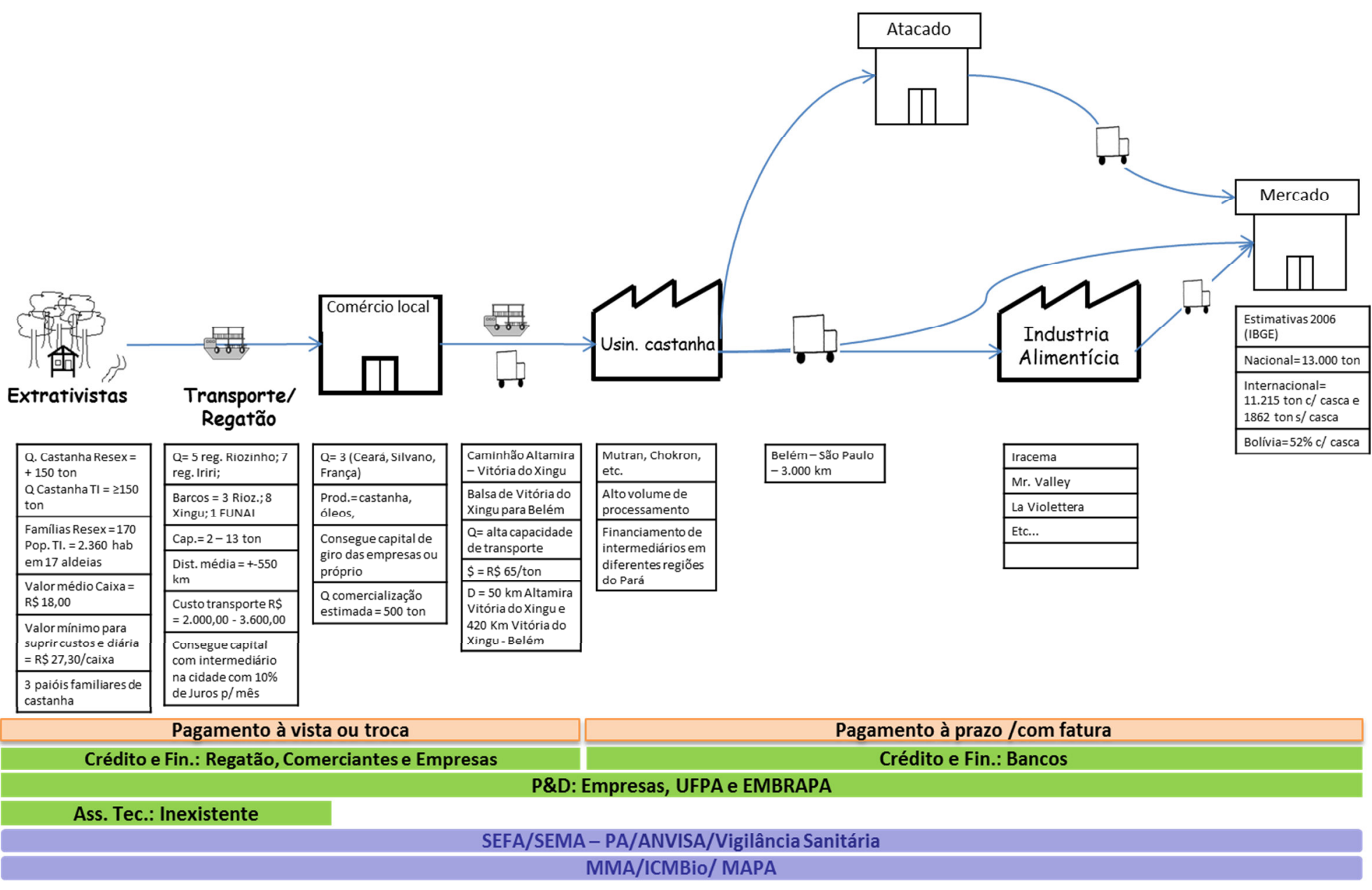

Figura 13: Mapa do Fluxo de Valor da Castanha em 2010. 
Esse processo de crédito e financiamento na Terra do Meio foi complementado por processos alternativos em 2008 com os primeiros trabalhos das instituições nas Resex. Inicialmente o crédito para início das atividades era dado pelas instituições em forma de alimentos e insumos de produção. Porém, esse sistema mostrou-se frágil por não possibilitar o fornecimento dos insumos corretos e no momento exato de necessidade de cada extrativista, fazendo com que ele recorresse ao regatão. Além disso, o sistema de apoio direto das instituições não abria muitas possibilidades para o ganho de autonomia das comunidades sobre os processos.

Em paralelo ao fomento das atividades produtivas foi iniciada pelas instituições uma busca por novos mercados para a comercialização dos produtos das Resex. Foram feitos contatos com comerciantes locais, regionais e nacionais e foram realizados diferentes estudos para possibilitar processos de negociação com as empresas. Os primeiros contratos foram estabelecidos em 2010 e 2011 com as empresas beneficiadoras de borracha Quirino e Mercur e a empresa de insumos químicos Firmenich, compradora de óleo de copaíba.

Com base em experiências passadas e a partir da negociação da comunidade do Riozinho do Anfrísio com a empresa Firmenich surgiu a proposta de instalação de capital de giro e cantina para comercialização do óleo de copaíba. Com o bom andamento da cantina da copaíba, posteriormente foram estabelecidos também sistemas de cantina para as cadeias da borracha, óleos vegetais e da castanha, que serão mais bem detalhados em tópicos futuros relativos a cada cadeia.

O sistema de cantina baseia-se na existência de um capital de giro dentro da Resex gerido por uma pessoa eleita pela comunidade, que é responsável por fazer o papel antes assumido unicamente pelo regatão, de venda de insumos e mercadorias e compra de produtos extrativistas. Ou seja, no momento em que o extrativista entrega sua produção ao cantineiro (ex: óleo de copaíba, castanha, borracha), ele recebe o pagamento em dinheiro ou troca parte do pagamento por bens de consumo disponíveis na cantina. O capital de giro existente hoje nas Resex foi fomentado por 
empresas interessadas em óleo de copaíba (Firmenich) e em borracha (Mercur) e também por instituições de apoio ao desenvolvimento das cadeias de valor dos PFNM (ISA e Imaflora). Dentre as melhorias trazidas por esse sistema em comparação às cadeias ligadas ao regatão e seu sistema de financiamento, pode-se citar:

- Aumento da autonomia e da organização da comunidade - o sistema de cantinas trouxe uma alternativa para venda de produtos e compra de mercadorias por parte dos extrativistas, reduzindo a dependência do regatão. As regras de funcionamento de cada cantina são definidas pelos próprios comunitários em reuniões. Isso levou a uma maior organização e autonomia da comunidade.

- Estabelecimento de parcerias comerciais - refletidas em contratos com empresas feitos a partir de acordos com a comunidade; o que dá mais segurança e transparência à cadeia de produção como um todo.

- Aumento do poder de compra dos extrativistas - resultante do aumento no preço pago pelos produtos extrativistas (previamente acordados entre as partes envolvidas) e da redução no preço dos bens de consumo disponíveis na cantina, em comparação com os valores estipulados pelo regatão (Quadro 8).

- Influência no valor do produto no mercado local - os melhores preços pagos na cantina pelos produtos extrativistas têm potencial influência sobre os valores estipulados pelo regatão, que necessita dos produtos para manter sua renda e passa a ter a concorrência da cantina.

- Acesso imediato a dinheiro e mercadoria por parte dos extrativistas - 0 capital de giro na mão do cantineiro dentro das Resex faz com que os extrativistas possam receber 0 pagamento por seus produtos no momento imediato da entrega; além disso existe disponível na cantina das Resex uma lista de mercadorias de fácil acesso aos comunitários. 
Quadro 8: Comparação entre valores de mercadorias cobrados pelo regatão e nas cantinas das

Resex.

\begin{tabular}{|c|c|c|c|c|}
\hline Produto & Unidade & Preço Regatão (R\$) & Preço Cantina (R\$) & Diferença \\
\hline Gasolina & L & 7,00 & 4,50 & 2,50 \\
\hline Diesel & L & 5,00 & 4,00 & 1,00 \\
\hline Arroz & $\mathrm{kg}$ & 6,40 & 3,40 & 3,00 \\
\hline Açúcar & $\mathrm{kg}$ & 3,50 & 2,60 & 0,90 \\
\hline Feijão & $\mathrm{kg}$ & 10,00 & 5,50 & 4,50 \\
\hline óleo & $\mathrm{L}$ & 7,00 & 4,60 & 2,40 \\
\hline Café & $250 \mathrm{~g}$ & 6,00 & 4,40 & 1,60 \\
\hline Sal & $\mathrm{kg}$ & 2,50 & 1,10 & 1,40 \\
\hline Milharina & pacote & 5,00 & 2,00 & 3,00 \\
\hline Leite em pó & pacote & 18,50 & 12,00 & 6,50 \\
\hline Coloral & pacote & 3,00 & 1,00 & 2,00 \\
\hline Sabão & pedaço & 1,40 & 1,00 & 0,40 \\
\hline Bombril & pacote & 5,00 & 1,70 & 3,30 \\
\hline Isqueiro & unidade & 6,00 & 4,00 & 2,00 \\
\hline Pilha & unidade & 3,00 & 2,10 & 0,90 \\
\hline Alho & $\mathrm{kg}$ & 20,00 & 15,60 & 4,40 \\
\hline Pimenta & pacote & 3,50 & 3,00 & 0,50 \\
\hline Creme dental & tubo & 6,00 & 4,00 & 2,00 \\
\hline Escova & unidade & 5,00 & 2,60 & 2,40 \\
\hline Sabão em pó & $500 \mathrm{~g}$ & 7,00 & 4,00 & 3,00 \\
\hline Bolacha & pacote & 5,50 & 4,20 & 1,30 \\
\hline Saco de fibra & unidade & 5,00 & 2,00 & 3,00 \\
\hline Facão & unidade & 80,00 & 35,50 & 44,50 \\
\hline Lima chata & unidade & 20,00 & 13,00 & 7,00 \\
\hline Cartucho (20) & unidade & 7,00 & 4,30 & 2,70 \\
\hline Chumbo & $\mathrm{kg}$ & 30,00 & 18,50 & 11,50 \\
\hline Espoleta & unidade & 2,50 & 0,80 & 1,70 \\
\hline
\end{tabular}

Fonte: Sistematização de informações levantadas no curso de gestão territorial da Terra do Meio.

Na Figura 14 está apresentado o novo mapa do fluxo de valor da castanha com o funcionamento do sistema das cantinas. 


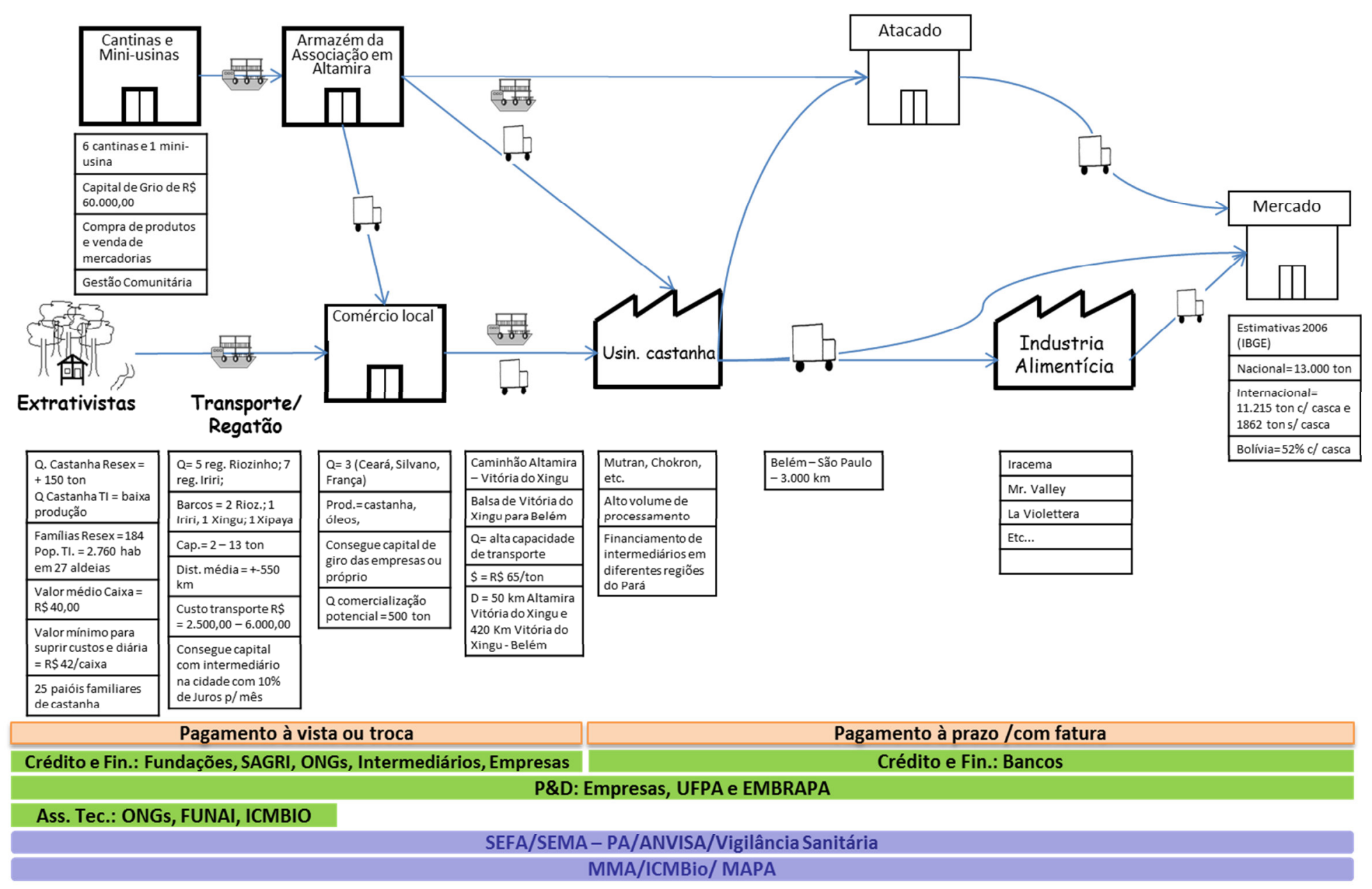

Figura 14: Mapa do Fluxo de Valor da Castanha com Cantinas em 2014. 
A estratégia das cantinas, associada a contratos comerciais, trouxe para as comunidades o controle sobre o capital de giro e a compra e venda de mercadorias. Esse sistema é semelhante ao sistema dos barracões, porém a gestão das cantinas é realizada pelo cantineiro e pelas comunidades e não mais pelo seringalista. No entanto, é importante evidenciar a necessidade de ações em saúde, educação, infraestrutura e na formação e acompanhamento técnico para que o processo seja realmente absorvido na dinâmica comunitária. Destaca-se que até 2007 havia $80 \%$ de analfabetismo nas Resex Riozinho do Anfrísio e Rio Iriri, sendo a conquista de direitos fundamental para o ganho de autonomia das comunidades.

Cientes dessa situação, as instituições de apoio vêm promovendo processos de formação com comunitários das Resex. Entre 2006 e 2007 os processos de diagnóstico socioeconômicos feitos na região tinham como parte do método de trabalho a alfabetização e a leitura de mundo da forma proposta por Paulo Freire (VASCONCELOS et al., 2010). Em abril de 2011 o ISA e a FVPP, com apoio do ICMBio, iniciaram o curso de gestão territorial das Resex da Terra do Meio, o qual visava preparar representantes das Resex na interlocução com a sociedade, principalmente com a nova realidade de moradores de Reservas Extrativistas. Paralelamente, houve um processo de formação específico para o cantineiro, permitindo que o mesmo tivesse acesso à informação e formação, melhorando suas habilidades de gestão.

Esses processos de formação ligados às demais atividades proporcionam um amadurecimento substancial dos extrativistas na relação com a sociedade e nos processos de negociação, especialmente com as diferentes organizações regionais.

Outra ação que buscou contemplar a demanda de agregação de valor aos produtos nas comunidades foi a instalação de infraestruturas de armazenamento e beneficiamento dos produtos extrativistas. Um projeto das Associações das Resex aprovado e financiado pelo PDRS Xingu permitiu o aluguel de um armazém em Altamira para os produtos extrativistas. Outra iniciativa apoiada pelas instituições foi a construção de estruturas simples para o armazenamento de castanha e borracha 
dentro das próprias Resex, além da criação de uma mini-usina para beneficiamento de PFNM na Resex do Rio Iriri. As Mini-usinas possuem a intenção de promover o beneficiamento multiprodutos de PFNM nas comunidades, agregando valor de forma adequada para diferentes mercados (local, institucional e nacional).

O detalhamento e histórico dos diferentes processos de melhoria de cada uma das cadeias de valor realizados pelas instituições do GT de atividades produtivas da Rede Terra do Meio é apresentado nos itens a seguir.

\subsection{2 Óleo de Copaíba}

O óleo de copaíba é retirado tradicionalmente pelos extrativistas e indígenas da região para uso caseiro. A partir da década de 1990 houve uma procura maior pelo óleo regionalmente, o que fez com que essa atividade extrativista se tornasse muito importante na região à montante do Riozinho do Anfrísio, complementando a renda familiar. Devido a essa importância, em 2008 foi realizado um estudo do potencial produtivo de óleo de copaíba da região, o qual trouxe alguns procedimentos e orientações complementares ao processo de extração. Em 2010 foi feita a primeira experiência de comercialização conjunta de parte da produção de copaíba de extrativistas do Riozinho do Anfrísio para a empresa Atina Ativos Naturais.

Visando apoiar o processo de coleta do óleo de copaíba, o ISA e a FVPP forneceram para os extrativistas interessados na venda desse produto, em forma de crédito, materiais necessários para a coleta do óleo e para alimentação. A busca da copaíba foi feita de forma coletiva, em "expedições" acompanhadas por um técnico do ISA. Durante este acompanhamento foi feito o mapeamento, plaqueamento e registro fotográfico das árvores de copaíba e, por demanda da empresa, os extrativistas tiveram que separar o óleo de acordo com sua coloração.

O produto demorou três meses para sair da Resex, ser organizado em Altamira 
e ter a documentação liberada (nota fiscal do produtor, autorização do ICMBio earranjos com a transportadora). Apenas após o final dos trâmites comerciais, que levaram cerca de dois meses para acontecer, foi depositado o pagamento na conta de um dos extrativistas, escolhido pelo grupo, que acabou sendo roubado. Esse processo ilustra a dificuldade na operação de processos comerciais por parte dos extrativistas, gerando aprendizados e sugestões de melhorias. Essa experiência causou desânimo dos extrativistas para a organização e venda coletiva do produto.

Em abril de 2011, através das articulações de mercado do Imaflora e do ISA, a empresa Firmenich interessou-se pela copaíba da região. Foi realizada uma reunião na Resex, onde a cadeia e o histórico regional foram apresentados, sendo estruturada a ideia de uma doação da empresa para a composição de um Fundo Rotativo da Copaíba que viabilizasse o recebimento imediato do pagamento. Para operacionalizar esse fundo os extrativistas optaram pela organização de uma cantina no Alto Riozinho, a ser administrada por um extrativista.

Na reunião foram feitos acordos de funcionamento da cantina e de relação com a empresa e foi celebrado um acordo de cooperação, entre Firmenich, AMORA,ICMBio, ISA e Imaflora de compra direta de até $1.300 \mathrm{~kg}$ de óleo de copaíba/ano por um período de 3 anos a um preço de $R \$ 25 / \mathrm{kg}$ (a ser renegociado anualmente). A comunidade responsabilizou-se em entregar o óleo em Altamira e assumir o valor de imposto de $12 \%$, bem como descontar uma ajuda de custo para 0 administrador da cantina, chamado de cantineiro.

Do Fundo de $R \$ 10.000,00$ ficou decidido que $R \$ 3.000,00$ ficariam em espécie (dinheiro) para pagamento a vista da produção dos extrativistas, conforme esses entregassem o óleo ao cantineiro, e $R \$ 2.000,00$ seriam disponibilizados em insumos (alimentação e equipamentos) que ficariam na cantina da Resex disponíveis para o acesso dos extrativistas.O restante do montante ( $R \$ 5.000,00)$ ficou guardado em Altamira. O ISA prestou apoio aos extrativistas na compra de vasilhames para transporte do produto, na organização das compras de mercadorias para a cantina, nos processos de treinamento e operação da comercialização 
(auxílio no controle de contas, emissão de nota e expedição do produto), na formação do cantineiro, bem comona sistematização dos dados de produção.

Os valores das mercadorias industrializadas disponibilizadas na cantina também foram definidos em reunião pelos extrativistas. $O$ preço de cada mercadoria comprada na cidade foi acrescido de um valor que contemplasse os custos de transporte e de perdas eventuais. Essas reuniões para a decisão do funcionamento da cantina trouxeram para os extrativistas um maior conhecimento das operações logísticas e da cadeia, aumentando a possibilidade de negociação e monitoramento.

O processo de comercialização estruturado da maneira descrita acima funcionou bem, sendo que todos os acordos foram cumpridos e os extrativistas conseguiram receber à vista o pagamento pelo óleo de copaíba entregue ao cantineirona Resex.

No segundo semestre de 2012 os extrativistas reuniram-se na cantina e demandaram novos acordos e valores para a empresa Firmenich. Em um primeiro momento foi enviada uma carta para o representante da empresa e posteriormente 0 cantineiro procedeu com as negociações por telefone no escritório do ISA. A Firmenich entendeu as demandas e modificou os valores inserindo os custos que não estavam sendo cobertos pela negociação anterior. O valor passou a contemplar mais especificamente os custos envolvidos no processo sendo que o quilo do óleo passou para $R \$ 32,00$. Desse valorainda são descontados $12 \%$ de ICMS, $R \$ 1,00$ de frete, $R \$ 2,50$ de ajuda de custo para o administrador e $R \$ 1,00$ para compra de vasilhames, restando $R \$ 23,50$ de dinheiro líquido na mão do extrativista.

A gestão da cantina da copaíba e as definições acordadas também se mostraram positivas. No monitoramento realizado em conjunto com o cantineiro verificou-se que o montante de recursos disponível aumentou para $R \$ 12$ mil. Esse acréscimo ocorreu tanto pela boa administração do cantineiro quanto pelo sobrepreço acordado sobre as mercadorias adquiridas pelos extrativistas nas cantinas. 


\subsubsection{Borracha Natural}

Entre 2006 e 2007, as organizações locais apontaram a demanda das populações das Resexde retornaras atividades com aborracha, principalmente na Resex Riozinho do Anfrísio. A partir da demanda dos extrativistas, as seguintes justificativas foram sistematizadas na época: (1) não existe uma atividade econômica que forneça às famílias uma renda fixa e confiável entre os meses de abril e novembro; (2) com a seringa, o extrativista pode estar em casa todos os dias, cuidando mais da família, de criações $^{14}$ e da roça; (3) há um conhecimento acumulado bastante grande sobre a atividade seringueira que pode se perder caso não seja reativada; (4) o preço da seringa é mais alto que o do peixe; (5) um seringueiro consegue calcular exatamente o quanto pode produzir periodicamente (por dia, semana, mês e ano) e prever a sua renda, diferente de outras atividades que são incertas como a copaíba e o peixe. Percebeu-se também que, associado a estas razões, existiaum certosaudosismo com relação à atividade de extração da borracha, retomando o "mito do passado de ouro".

Em 2007, as instituições envolvidas com as cadeiais de valor da Terra do Meio optaram por iniciar um pojeto piloto com seringueiros do Riozinho do Anfrísio. Em conjunto com os extrativistas, em reuniões nas Resex, foi estruturada uma forma de apoiar a reabertura dos seringais com: (1) compra de utensílios (facão, tijelas, botina, combustível, etc) e (2) compra de rancho ${ }^{15}$ para os extrativistas e suas famílias durante o período de reabertura dos seringais. O projeto não incluiu a responsabilidade pela comercialização. Ficou claro que os próprios seringueiros deveriam ficar responsáveis pela venda do produto no preço de mercado (na época

${ }^{14}$ Criações é denominação dada pelos ribeirinhos para a criação de pequenos animais como patos, galinhas e porcos, por exemplo.

${ }^{15}$ Rancho é a alimentação básica da família extrativista (sal, açúcar, café, óleo, etc.). 
$R \$ 1,60 / \mathrm{kg}$ de borracha prensada) através da venda para os regatões que já compravam deles e/ou para compradores da cidade. Com estas condições postas em reunião realizada em dezembro de 2007 , candidataram-se inicialmente dezoito seringueiros para fazer a revitalização de seus seringais.

Em 2008 foram realizadas diversas reuniões com esses extrativistas, intercâmbios e a colaboração entre ICMBio, ISA, WWF, FVPP e IPAM para promover a retomada da atividade seringueira. Esse foi o mesmo ano de criação do GT de Atividades Produtivas que iniciava as discussões sobre as possíveis estratégias para as atividades produtivas nas Resex.

Nas reuniões comunitárias foram dialogadas as práticas de manejo dos seringais, foram entregues os mantimentos e materiais de corte com preços subsidiados pelas organizações e foi assinado um acordo entre organizações e seringueiros. O mesmo continha os produtos recebidos e quanto deveriam retornar para a associação de moradores, com a finalidade de financiar novos projetos. $\mathrm{O}$ acordo assinado com os extrativistas previa naquela safra a devolução de apenas $1 / 3$ dos recursos financiados pelas organizações de apoio, que visavam o incentivo da cadeia.

Paralelamente, iniciou-se uma sequência de conversas com comerciantes locais para compra da borracha produzida. Para melhorar o preço foram realizadas tentativas de acesso a subsídios governamentais para a produção, envolvendo uma parceria entre organizações do GT de Atividades Produtivas, extrativistas da Terra do Meio, produtores de borracha da transamazônica, comerciantes locais, o ICMBio e a Companhia Nacional de Abastecimento (Conab).

Esse processo viabilizou $\mathrm{o}$ acesso dos produtores de borracha da transamazônica ao Programa de Garantia de Preço Mínimo (PGPM) em 2010. Porém, os extrativistas das Resex não conseguiram acessar o programa por não possuírem a Declaração de Aptidão ao Pronaf (DAP), que é um documento requerido para acessar esse direito e outras políticas públicas voltadas a assentados 
da reforma agrária e moradores de Unidades de Conservação de uso sustentável, Terras Indígenas e Quilombolas.

Na safra de 2009 o projeto de revitalização dos seringais foi estendido para as Resex Rio Iriri e Rio Xingu. O processo continuou com o mesmo formato anterior, sendo a safra e os insumos financiados com recursos da GTZ, através do ISA e da FVPP. Nesse períodohouve maior aproximação do ISA e do Imaflora de duas empresas parceiras da cadeia de borracha, a Mercur e a Quirino. Essa aproximação resultou na visita de representantes da Mercur às Resex Riozinho do Anfrísio e Rio Iriri, com a realização dereuniões entre os seringueiros das trêsResex, a Mercur e as organizações de apoio.

Vale destacar a mudança de paradigma de negócios que a empresa Mercur vem passando, em busca de padrões mais éticos de negócio. Estimulada por mudanças no cenário e por novas lideranças, a empresa vem reduzindo seu impacto socioambiental, buscando trabalhar em mercados éticos, restringindo o uso de insumos perigosos e buscando relações justas com colaboradores e fornecedores. Essa mudança de paradigma aliada ao contato com colaboradores do Imaflora proporcionou o interesse da empresa em retomar a aquisição de insumos da Amazônia, em especial das Resexda Terra do Meio, onde o Imaflora já possuía atuação.

Nas reuniões comunitárias foi elaborado um termo de cooperação assinado pelos representantes das três Associações das Resex, ISA, Imaflora, FVPP e ICMBio. Em suma, a Mercur estabeleceu três anos (safras de 2010, 2011 e 2012) de compra da borracha em bloco pelo preço de $R \$ 4,00 / \mathrm{kg}$. Esse valor teve como referência os estudos realizados pelo Imaflora no começo do ano. Conforme orientado pela própria Mercur, o bloco de borracha virgem prensada foi vendido diretamente para a empresa transformadora Quirino Borrachas, que o processou, padronizou e revendeu para a Mercur.

A parceria funcionou bem e tomou como base o processo de comercialização 
já adotado pela Associação Agroextrativista Sementes da Floresta (AASFLOR) e pela cadeia da copaíba, com a comercialização através da emissão de Nota Fiscal de Produtor Rural por parte do extrativista diretamente na Secretaria da Fazenda do Estado do Pará. Para viabilizar o transporte da borracha para São Paulo a empresa Quirino Borrachas articulou com o comerciante local de borracha a compra de parte de sua produção em conjunto com a borracha oriunda das Resex.

Em 2011 houve um aumento considerável de extrativistas participando do projeto e a inexistência de regatões atuando neste mercado. A oportunidade de venda por um preço melhor e a experiência de venda positiva dos vizinhos em 2010 motivaram outras famílias a participarem da atividade de venda da borracha para as empresas. Entretanto, alguns gargalos foram identificados nesse processo ao longo dos anos, como: a necessidade de colocação de "estradas de seringa", que são trilhas abertas dentro da mata por um especialista (o "mateiro") com o intuito de criar um caminho lógico que passe pelas seringueiras do extrativista e otimize o seu processo de extração; a falta de alimentos, mercadorias e insumos básicos necessários à safra, acessíveis aos extrativistas; a inadimplência por parte de alguns seringueiros com relação ao pagamento das mercadorias adquiridas junto às organizações de apoio.

Nesse mesmo ano, através das idas às Resex de técnicos da empresa, foi desenvolvida uma nova tecnologia para o pré-beneficiamento da borracha, denominada de Manta de Borracha Seca (MBS). Ficou acordado que essas poderiam ser comercializadas diretamente para a Mercur pelo preço de $R \$ 6,00 / \mathrm{kg}$, retirando a necessidade de processamento na Quirino. A adoção da técnica pela comunidade foi parcial, que ainda beneficiou a maior parte da produção em blocos e apenas uma menor parte em MBS.

Em 2012 foram mantidos os valores e o sistema de apoio do ano anterior, dessa vezoperado pela FVPP. O número de seringueiros participantes permaneceu o mesmo, mas a produção diminuiu $43 \%$ em relação a do ano anterior. 
Buscando fortalecer as relações e aumentar o entendimento dos seringueiros sobre a cadeia, foi realizado um intercâmbio com as empresasem 2012, com a participação de um seringueiro de cada Resex. Nessa viagem, os extrativistas, acompanhados pelo ICMBio, ISA e Imaflora, puderam conhecer o processo produtivo final da cadeia da borracha, os seringais plantados no sul, ampliar sua consciência sobre o projeto e negociar novas condições para o mesmo.

Nesse mesmo ano o início da participação da empresa Quirino no comércio local de borracha trouxe consequências para as transações comerciais da região. A empresa que costumava comprar borracha do comerciante de Altamira, sabendo que parte da produção desse comerciante estava sendo vendida para a Quirino, deixou de pagar parte da produção enviada pelo comerciante e declarou à Conab que não recebia produção dos agricultores e extrativistas beneficiários do PGPM da região.

Disso resultou o cancelamento do pagamento dos subsídios desses agricultores, a descapitalização do comerciante local e a estruturação de um estudo entre comerciante, ISA e agricultores para comprovar que existia produção, que a mesma havia sido enviada para a empresa e que era viável para a Quirino manter e ampliar a parceria com o comerciante local. Comprovada a existência de produção, os agricultores voltaram a receber o subsídio e a relação comercial do comerciante passou a ser realizada totalmente com a Quirino.

Em 2012 foi iniciado um estudo etnográfico por um antropólogo especialista nas populações extrativistas da Amazônia, tendo como um dos objetivos 0 entendimento das relações de produção e comercialização nas Resex. Como resultado a pesquisa apontou que a quantidade de mercadorias fornecidas pelas organizações e sua entrega antecipada aos extrativistas não estavam sendo suficientes para o desenvolvimento da atividade familiar na seringa, uma vez que os alimentos fornecidos não supriam suas necessidades na totalidade, o que acabava levando os extrativistas para outra atividade que proporcionasse o devido recurso no momento da necessidade, como a pesca. Esse teria sido um dos motivos da 
inadimplência no pagamento dos alimentos por parte de alguns seringueiros, aliado à dificuldade de colocar estradas de seringa sem o suporte de mateiros especializados.

Com base nesse estudo e na experiência da cantina da copaíba decidiu-se iniciar em 2013 a estruturação de cantinas para a cadeia da borracha. Em Julho de 2013 um dos donos da empresa Mercur veio para as Resex para conhecer a região e renegociar valores e condições para a cadeia. A visita possibilitou um entendimento mais profundo da realidade local, modificada especialmente pela construção da UHE Belo Monte (preço de mercadorias, pressão sobre a pesca, aumento do valor das diárias, etc), e viabilizou modificações na estruturação da parceria.

Foram realizados diálogos sobre abertura de estradas de seringa, métodos de extração e produtividade dos seringais, sendo planejadas ações de melhoria nos processos extrativistas e de gestão. A empresa e as organizações envolvidas comprometeram-se a pesquisar utensílios de extração mais parecidos com os utensílios antigos, a apoiar a estruturação das cantinas e do capital de giro necessário, e a estudar as possibilidades de preço dentro das propostas feitas pelos seringueiros.

A Mercur, o ISA e o Imaflora doaram para as Associações o recurso financeiro necessário para a estruturação das cantinas para a safra de 2013. Considerando as horas de trabalho dos seringueiros para a extração da borracha, o custo dos insumos de produção e o valor da diária local de $R \$ 40,00$, foi definido o novo preço de $R \$ 6,60$ por quilograma de borracha, sendo que desse total, $R \$ 0,50 / \mathrm{kg}$ devem ser destinados à remuneração do cantineiro.

Porém, esse valor está muito acima do valor nacional de mercado baseado no plantio de seringueiras, de cerca de $R \$ 2,00 / \mathrm{kg}$, e pode onerar muito a cadeia e 0 produto final, tornando o mesmo pouco competitivo. A justificativa apresentada ao mercado para o maior valor dos produtos das Resex deve ser atrelada a qualidade 
diferencial desses produtos de terem em sua concepção um maior valor agregado associado a um serviço sociocultural-ambiental. Isso porque o estímulo a cadeias de produtos extrativistas da Floresta Amazônica ajuda a:

- Preservar a floresta, pois a forma tradicional do extrativismo favorece essa preservação (serviço ambiental);

- Promover o modo de vida dos extrativistas, pois os conhecimentos existentes sobre a floresta, seus produtos e sua dinâmica são fundamentais para a conservação da mesma e a continuidade desse conhecimento passa pelos PFNM. (serviço cultural);

- Merlhorar a renda dos extrativistas através do extrativismo e a melhorar a qualidade de vida deles na floresta (serviço social).

Ou seja, a empresa está comprando em conjunto com a borracha a cultura envolvida nessa atividade, sua história e os serviços prestados pelos seringueiros na conservação das Reservas Extrativistas. Percebeu-se que ter um produto tradicional competitivo com relação a outras atividades mais degradantes é favorecer a continuidade e evolução da cultura e modo de vida que apoiou a conservação dessas áreas nos últimos anos. Uma possibilidade em estudo é a divisão em produto, subsídios do governo e Pagamentos por Serviços Sociombientais.

\subsubsection{Castanha do Pará}

As populações extrativistas da Terra do Meio extraíam a castanha para comercialização na entressafra da seringa para os patrões. Com a queda da seringa a castanha passou a assumir importante papel na renda familiar em conjunto com outras atividades, tais como pele de animais e garimpo.

O levantamento socioeconômico realizado em 2007 pelo IBAMA (2007a) apontou que a castanha representava $37,9 \%$ da renda dos moradores da Resex 
Riozinho do Anfrísio, constituindo sua principal renda, e $30 \%$ da renda dos moradores da Resex Rio Iriri, atrás apenas do peixe, que representava $42 \%$ da renda (IBAMA, 2007a). O preço da castanha variava entre $R \$ 0,50$ a $R \$ 1,00$ na safra, de Janeiro a Abril, e de $R \$ 0,75$ à $R \$ 1,25 / \mathrm{kg}$ na entressafra, de Maio a Dezembro (IBAMA, 2007a). Em 2005 a castanha era comprada dos indígenas da região a um valor de $R \$ 1,50 / \mathrm{kg}$ pela cooperativa Amazoncoop, havendo uma produção aproximada de 37 toneladas de castanha das Terras Indígenas da região do médio Xingu (RIBEIRO F., 2009).

Com o fim da Amazoncoop em $2008^{16}$ toda a castanha produzida na região voltou a ser negociada somente com os comerciantes locais e vendida para Belém. Com isso a safra de 2009 foi vendida pelo menor preço dos últimos anos pelos moradores das Resex, chegando a $R \$ 0,50 / \mathrm{kg}$. Por ser um dos principais produtos da região, o ISA apoiou alguns extrativistas para comercialização na entressafra em 2009, comercializando a castanha a $\mathrm{R} \$ 0,80 / \mathrm{kg}$.

Com base nessa experiência, iniciou-se em 2010 um projeto para armazenamento da castanha colhida na safra, de modo que ela pudesse ser vendida na entressafra a preços melhores. Para esse armazenamento idealizou-se a construção nas Resex de estruturas de madeira protegidas do sol e da chuva, com ventilação e limpeza adequadas, denominadas de paióis. Os paióis também possibilitariam a melhoria da qualidade do produto, favorecendo a secagem adequada da castanha e viabilizando as boas práticas de manejo, que também poderiam aumentar o preço de venda.

Seguindo o modelo da cadeia da borracha, foram realizados pelas organizações adiantamentos em alimentação e material para a construção de alguns

${ }^{16}$ Para Ribeiro F. (2009) a Amazoncoop teve o trabalho com a castanha suspenso em 2006. Porém no trabalho realizado em 2006 e 2007 na região foi feita uma visita com representantes das Resex à cooperativa, que passou a funcionar em um local afastado da ciadade. 
paióis nas Resex Riozinho do Anfrísio e Rio Iriri e para o financiamento da safra.

A adesão ao projeto proposto pelo ISA e FVPP era voluntária e por organização própria dos extrativistas, gerando uma organização por núcleos familiares que culminou na construção inicialmente de três paióis de 4 por 6 metros em diferentes localidades das Resex. Paralelamente, o ISA e o Imaflora passaram a prospectar mercado para a castanha com empresas da região além de dois compradores de Altamira. Neste ano a melhor alternativa encontrada foi ainda em Altamira, pelo preço $\mathrm{R} \$ 1,60 / \mathrm{kg}$.

Em 2011 foi repetido o apoio em material e alimentação para as famílias que solicitaram no Riozinho do Anfrísio e no Rio Iriri. Também foram construídos paióis, de acordo com o interesse da família em continuar armazenando a produção.

Nesta safra a produção dos castanhais nas Resex foi excepcionalmente baixa e a comercialização do produto foi difícil. A produção de $2.025 \mathrm{~kg}$ foi vendida a um preço de $R \$ 2,40 / \mathrm{kg}$, com um aumento significativo comparado a 2010. Porém, esse aumento ocorreu mais por conta da baixa oferta de castanha no mercado do que pelas práticas de manejo e negociação implementadas. No entanto, por estar em dificuldades financeiras a empresa só pagou parte desse valor.

O ISA e o Imaflora continuaram a prospectar outros mercados e encontraram a empresa Ouro Verde, que já comprava a castanha da TI Kayapó. A empresa buscava pagar valores mais justos por castanhas manejadas e de boa qualidade.

Em janeiro de 2012, apesar de não estabelecer contrato, foi firmado o compromisso com a Ouro Verde em manter o preço de compra a $R \$ 2,40 / \mathrm{kg}$ de castanha manejada até o final da safra, porém sendo de responsabilidade do extrativista em parceria com as organizações locais pagar o ICMS e o frete para Altamira. A castanha não manejada foi inclusa nas negociações a um valor menor, de $R \$ 2,10 / \mathrm{kg}$. Nesse mesmo ano as associações das Resex conseguiram um projeto pelo PDRS Xingu, com apoio do ISA, adquirindo insumos de produção e garantindo o aluguel de um barracão em Altamira para o armazenamento da 
produção na cidade.

Como havia dificuldade para armazenar as castanhas não manejadas, pela falta de paióis, tentou-se uma segunda estratégia de organização com as comunidades. Foram escolhidos dois "agentes da Castanha" no Riozinho do Anfrísio, um indicado pela comunidade e com experiência em comercialização e o segundo já apoiava o ISA em suas atividades de campo e participava do Curso de Gestão Territorial ofertado por essa instituição.

O ISA fez alguns acordos individualmente com os agentes de comprarem a castanha por preços justos, com o dinheiro e alimentação adiantados pela instituição, sendo o preço das mercadorias acordado entre as partes. Ao contrário da copaíba esse processo não contou com uma reunião e acordos diretos com a comunidade.

O arranjo funcionou e foram comercializados com valores diferenciados 10 toneladas de castanha, com um dos maiores valores já pagos na região. Esse resultado satisfez os extrativistas promovendo a ampliação dos participantes no ano seguinte. Os agentes de castanha acabaram por competir diretamente com os regatões, trabalhando algumas vezes nos mesmos moldes que estes já estavam trabalhando.

A venda para os regatões por parte dos extrativistas manteve-se tanto por endividamento prévio quanto por relações de reciprocidade existente entre os mesmos. Porém, o valor da nova parceria influenciou o mercado local, e o preço praticado pelos regatões passou de $R \$ 1,25 / \mathrm{kg}$ no começo da safra para até $R \$$ $2,00 / \mathrm{kg}$ no final da safra.

Em 2013 a Ouro Verde anunciou novamente interesse na compra da castanha a $R \$ 2,40 / \mathrm{kg}$. No início de janeiro os recursos de apoio à produção do Riozinho e Iriri (insumos, alimentação e dinheiro) foram entregues juntamente com explicações dos técnicos das instituições e um informativo sobre os combinados com a Ouro Verde. No Riozinho do Anfrísio foi feita ainda reunião com a Associação de Moradores e 
extrativistas para combinar a safra e a responsabilidade de cada parte. Nessa reunião também foi melhor esclarecido o papel dos agentes da castanha e foi levantada a possibilidade de cantinas para a castanha, nos moldes da cadeia da copaíba.

O arranjo da castanha funcionou como esperado e mais uma vez elevou o valor da castanha pago pelos regatões, que foi em média de $R \$ 1,50 / \mathrm{kg}$. A castanha foi enviada para Altamira e armazenada no galpão alugado pelas associações. Porém, em abril de 2013 a Ouro Verde informou o ISA que não poderia comprar a castanha nesse ano, pois o valor de mercado da castanha sem casca havia caído de uma média de $R \$ 21,00 / \mathrm{kg}$ para $R \$ 13,50 / \mathrm{kg}$ o que inviabilizava uma remuneração justa para os fornecedores, preferindo a empresa ficar sem beneficiar a castanha do que ter que remunerar as comunidades a um valor abaixo do considerado justo pela mesma.

Pesquisando o mercado, percebeu-se que a grande safra de 2012 gerou estoque nos beneficiadores (nacionais e bolivianos) e atacadistas, o que pressionou o valor para baixo em 2013, reduzindo também o valor pago aos extrativistas. Porém, o valor praticado pelos varejistas manteve-se estável nas gôndolas dos supermercados.

Para viabilizar o pagamento dos extrativistas, oito toneladas de castanha foram comercializadas para o comerciante local Silvano Bonfim a um valor de $R \$ 2,00 / \mathrm{kg}$, valor melhor do que o pago durante a safra localmente, porém menor do que o valor acordado com os extrativistas.

A queda de preço e as comunicações com a Ouro Verde geraram algumas ações para a cadeia da castanha. O Imaflora começou um estudo mais profundo da cadeia como um todo para tentar influenciar as empresas chave, especialmente varejistas. O estudo ligado a ações junto às instituições representativas das empresas visava a estruturação de acordos para a mudança progressiva das relações na cadeia da castanha e o melhor monitoramento da mesma. 
Outra ação foi a negociação com empresas beneficiadoras para a terceirização do beneficiamento da castanha. Essa negociação foi realizada com a empresa Ouro Verde e com uma empresa de Belém, que tem o comerciante Silvano Bonfim como sócio.

Para viabilizar a terceirização foi estruturado e aprovado um projeto da Associação dos Moradores do Riozinho do Anfrísio (AMORA) junto ao Fundo Social do Imaflora. Esse recurso foi aprovado e serviu para remunerar a empresa pelos serviços de beneficiamento. O Imaflora teve interesse no financiamento do processo pelo fato do mesmo representar uma possibilidade de agregar valor à castanha pelo seu beneficiamento e pela possibilidade de conseguir informações diretamente do mercado.

Todo o processo foi notificado aos extrativistas ao longo do tempo através dos técnicos de campo e via rádio, porém os mesmos não tiveram participação ativa na tomada de decisão sobre a comercialização da castanha. Isso ocorreu tanto pela dificuldade de conseguir organizar reuniões com enfoque nesse assunto quanto pela urgência na resolução da questão. A participação dos extrativistas no processo ocorreu via representantes das associações que periodicamente estão em Altamira para reuniões do PDRS Xingu.

Por fim, houve uma reaproximação da Ouro Verde em Agosto de $2013 \mathrm{com}$ a intenção de comprar a castanha restante a um valor de $R \$ 2,6 / \mathrm{kg}$. O ISA optou, então, pela venda de parte da castanha para a Ouro Verde e pela realização do teste de beneficiamento e comercialização de cinco toneladas de castanha beneficiada.

Em uma força tarefa conjunta, o ISA e o Imaflora determinaram junto à empresa o arranjo comercial, os acordos, as datas de beneficiamento para acompanhamento, rótulos e embalagens. A empresa se dispôs a abrir as informações de custos de produção e informações de mercado para viabilizar a precificação do produto e os estudos da cadeia em andamento pelo Imaflora. 
No final de 2013 foram realizadas reuniões nas comunidades das Reservas Extrativistas para conversar sobre as atividades do ano e planejar como poderiam ser as atividades em 2014. Destacou-se que, pelas demandas das comunidades e pelos resultados positivos com a copaíba, o ISA optou por não mais gerenciar diretamente o apoio com crédito individual aos castanheiros, preferindo apoiar a estruturação de cantinas nas comunidades, com gestão do capital de giro pelos extrativistas e apoio aos cantineiros.

As definições de localização das cantinas e de seus responsáveis foi realizada pelas comunidades com acompanhamento de dois colaboradores do ISA, sendo definidas para 2014 a organização de três cantinas no Riozinho do Anfrísio e três cantinas no Rio Iriri. Com isso a comunidade passaria a ter maior controle sobre 0 crédito para safra e sobre a gestão e monitoramento das primeiras atividades da cadeia da castanha, que envolve: disponibilidade de crédito, compra de insumos, comercialização de mercadoria, transporte coletivo para Altamira, armazenamento e comercialização conjunta.

Um dos locais escolhidos pela comunidade na Resex Rio Iriri foi o Rio Novo, local onde funciona a Mini-usina de PFNM. Nesse local, além da gestão do capital de giro/cantina a comunidade está operando outras etapas da cadeia, fazendo também o beneficiamento, embalagem, transporte e comercialização no mercado local, como apresentado na descrição do processo da Mini-Usina a seguir.

\subsubsection{Mini-usinas de PFNM}

A mini-usina de PFNM é um conceito em desenvolvimento na região da Terra do Meio, que busca viabilizar através de tecnologias adequadas o beneficiamento dos produtos comunitários para consumo e comercialização. Os principais produtos beneficiados na mini-usina em 2014 são: óleos e manteigas vegetais (babaçu, 
castanha, andiroba, cupuaçu, cacau), sabonetes, mesocarpo de babaçu e castanha desidratada.

As primeiras mini-usinas foram instaladas na região rural do município de Uruará pelo Projeto Sementes da Floresta (PSF). O PSF foi uma iniciativa da Associação Cultura Franciscana (ACF) em conjunto com as comunidades ligadas ao Centro Comunitário Nossa Senhora de Guadalupe, localizado no município de Uruará, PA - Km 200 da Transamazônica.

O PSF envolve 31 famílias, 155 pessoas de 7 comunidades, uma área de uso direto de aproximadamente 3.100 hectares nosprojetos de assentamento (PA) Rio Trairão e Uirapuru e uma área requerida de uso coletivo de 12.000 hectares no PA Rio Trairão. A coleta, seleção, secagem e extração dos oléos é realizada nas comunidades por duas mini-usinas. Para poder conciliar as atividades da agricultura familiar com o extrativismo ou a extração de óleo é adotada uma dinâmica de trabalho coletivo ou "multirão" por comunidade envolvida no projeto. O projeto é gerido por um conselho gestor (duas pessoas por comunidade) que é reponsável pela contabilidade da comunidade e gestão da mini-usina. O planejamento e as decisões da comunidade são tomadas por meio de assembléia geral dos produtores.

Desde seu início o projeto teve parceria com a empresa Naturais da Amazônia, a qual era responsável pela assistência técnica, compra e comercialização dos óleos vegetais. Esta empresa estimulava a estruturação de processos de beneficiamento simples em comunidades, sempre com a participação de uma terceira instituição de apoio na organização comunitária. Os valores praticados pela empresa eram, normalmente, maiores que os valores de mercado e seu principal canal de escoamento era o exterior.

A parceria foi quebrada em 2012, por desacordos e falta de pagamento, aumentando os desafios para o PSF. Em 2013 o projeto se formalizou como 
Associação Agroextrativista Sementes da Floresta $\left(\right.$ AASFLOR $^{17}$ ) e a comercialização passou a ser concentrada principalmente no mercado local de Uruará, de forma fracionada, para óleos e sabonetes e para alimentação escolar (mesocarpo de babaçu).

Além da parceria com a empresa Naturais da Amazônia a AASFLOR desenvolveu laços importantes com outras instituições locais, especialmente 0 Ideflor, a FVPP e o ISA. A AASFLOR começou a participar do GT de atividades produtivas da RTM em 2010, no processo de planejamento regional, e aumentou sua relação com as Resex através de intercâmbios constantes. Essa aproximação das instituições e redes locais trouxe maior visibilidade para a associação e viabilizou a inserção da mesma nos projetos e atividades das instituições regionais. Viabilizou, também, o suporte em estudos e articulações voltadas à legalização fundiária das áreas extrativistas das comunidades que estavam sendo invadidas.

Nas Resex sempre existiu uma pequena produção artesanal de óleo vegetal (andiroba, babaçu e castanha) para uso familiar, havendo diálogos entre instituições e comunidades para o aproveitamento das oleaginosas na região. A implantação de uma unidade de beneficiamento começou a ganhar corpo com projetos do ISA e com a realização de dois intercâmbios com a AASFLOR em 2010. Esses foram importantes para aumentar o entendimento dos extrativistas sobre os processos e tecnologias e confirmar o interesse pela implantação da mesma localmente.

Em 2011 foram adquiridas as máquinas para a mini-usina nas Resex. Dentre as localidades das Resex que participaram dos intercâmbios e treinamentos, a localidade do Rio Novo, na Resex Rio Iriri, apresentou-se como a mais propícia para a implantação do projeto piloto da mini-usina. Os motivos apontados foram:

\footnotetext{
${ }^{17}$ A sigla AASFLOR será utilizada ao longo do texto para representar a associação/PSF.
} 
- O alto engajamento das famílias do Rio Novo nos intercâmbios, na operaçãodas máquinas e participação das discussões;

- O fato de ser uma localidade com várias famílias e vizinha de outras localidades de maior agregação populacional;

- A família que ficou responsável pela mini-usina nessa localidade possui uma vasta rede de relacionamento, com bons laços e poucos conflitos, com as comunidades vizinhas e com pessoas de Uruará e Altamira;

- Maior proximidade das cidades de Altamira e Uruará em relação a outras localidades;

- Há acesso por terra até um ponto muito próximo da localidade, via estrada da Maribel; região de passagem dos moradores do Riozinho do Anfrísio e Rio Iriri, bem como de pessoasprovenientes do porto da Maribel.

Assim, em Agosto de 2011, foi inaugurada a mini-usina do Rio Novo com um investimento aproximado de $R \$ 70.000,00$. Após sua inauguração, os ciclos de intercâmbios foram mantidos, ocorrendo três intercâmbios na unidade com moradores das três Resex, AASFLOR, ISA, Imaflora, Funai e FVPP.

Participaram também desses intercâmbios, o fabricante dos equipamentos e o representante da empresa Naturais da Amazônia, sendo estabelecido um acordo de compra entre as comunidades e esta empresa. Porém, este nunca precisou ser operacionalizado pelos extrativistas, pois todo o óleo produzido era consumido pelas próprias famílias ou negociado no mercado local.

No primeiro intercâmbio foram definidas algumas regras e acordos de funcionamento da mini-usina, tais como:

- $20 \%$ da produção de óleo devem ser destinados a cobrir custos da usina e da mão-de-obra;

- Somente pessoas treinadas podem operar as máquinas;

- A mini-usina é de toda a Resex, porém a responsabilidade na operação e manutenção é da família responsável; 
- A coleta dos produtos extrativistas e o seu transporte até a mini-usina é de responsabilidade do extrativista, podendo o mesmo levar o óleo resultante do beneficiamento ou deixá-lo para ser comercializado pela mini-usina;

Essas regras foram definidas pelos extrativistas, com apoio das instituições, em diálogos ao longo do intercâmbio. O processo possibilitou a participação dos extrativistas, porém não havia informações suficientes para a tomada de decisão sobre valores e porcentagens. Essas decisões foram pautadas na experiência dos extrativistas e em valores que os mesmos achavam possíveis. $O$ valor do produto, em um primeiro momento, foi basedao no valor praticado pela empresa Naturais da Amazônia.

Com relação ao funcionamento, a mini-usina segue uma divisão de trabalho familiar. Os pais são os principais responsáveis pelo extrativismo das sementes e pelo processamento dos óleos. As filhas são responsáveis pela casa e, por terem algum estudo, pela parte gerencial, controlando a entrada e saída de produtos, as anotações de produção e a parte contábil.

A pouca escolaridade familiar traz dificuldades para o entendimento dos controles escritos, sendo necessário um processo constante de treinamento e acompanhamento para a formação em gestão. Em 2012 as jovens passaram a frequentar a escola rural de Uruará, por articulações e negociações da Associação dos Extrativistas do Rio Iriri-Maribel (AERIM). O acompanhamento técnico buscou estruturar a gestão da mini-usina de forma gradual, de acordo com o aprendizado das famílias envolvidas. Assim, o crescimento gradual da demanda e das melhorias foram importantes para acompanhar o aprendizado em gestão.

Fazem parte do controle da mini-usina:

- Anotações das informações sobre a coleta - data, número de pessoas, tempo, quantidade; 
- Anotações sobre os processos de beneficiamento - data, número de pessoas, pesos das matérias-primas, peso do produto acabado, retirada de percentuais;

- Anotações sobre comercialização - data, comprador, quantidade vendida, preço, elaboração de recibos. Para a comercialização, no caso de venda externa é realizada a emissão de nota fiscal do produtor rural na Secretaria da Fazenda do Estado do Pará em Altamira, com apoio técnico do ISA.

Em meados de 2012 a mini-usina adquiriu licença de funcionamento pela Vigilância Sanitária,com apoio do ISA, viabilizando outros canais de comercialização no mercado local. Os produtos também adquiriram rótulos simples, embalagens, análise química e cartilhas de boas práticas com apoio do Imaflora.

Com isso, foram feitas novas experiências de venda na cidade, com enfoqueno varejo. A venda dos produtos rotulados na cidade foi realizada pela família responsável e por assessores do ISA. Os rótulos propostos não estavam adequados para a comercialização em supermercados, sendo necessárias adequações, feitas em 2014. Porém, a comercialização direta e para comerciantes da feira municipal e para moradores das Resex tem sido o suficiente para a produção realizada de óleo e mesocarpo.

\subsubsection{1 Óleos Vegetais}

O primeiro produto processado pela mini-usina foi o óleo de babaçu, que tem grande potencial produtivo principalmente devido à abundância da espécie na região. No início da implantação da mini-usina os custos de produção não eram claros e a definição do valor de venda foi feita pelo mercado local. As primeiras experiências de comercialização exclusiva dos extrativistas em Altamira resultaram em um valor médio de $R \$ 15,00 / \mathrm{kg}$ de óleo de babaçu; valor este maior que o 
sugerido pela empresa Naturais da Amazônia e que passou a ser praticado localmente. Com o acompanhamento técnico e as anotações realizadas pelos extrativistas, percebeu-se que um valor compatível com a diária local, considerando o esforço de coleta e beneficiamento da amêndoa, deveria ser de aproximadamente $\mathrm{R} \$ 28,00 / \mathrm{kg}$.

Até 2012 a produção do óleo de babaçu na mini-usina no Rio Novo era restrita à produção da própria localidade, devido a dificuldades logísticas e de comercialização dos demais extrativistas das Resex. Os demais extrativistas tinham dificuldades logísticas para levar as amêndoas de babaçu até a localidade da miniusina para a extração de óleo, e também para levar o óleo processado até Altamira e comercializá-lo. Essa dificuldade era agravada pelo fato do pagamento pelas amêndoas só ocorrer após a venda do óleo em Altamira, o que poderia levar meses. As famílias da localidade Rio Novo tinham maior facilidade para comercializar o óleo que processavam devido a suas relações e tinham necessidade de aumentar 0 volume de óleo produzido, que já se tornava referência na região.

Durante o intercâmbio de 2012 os extrativistas sugeriram que a mini-usina passasse a comprar a amêndoa dos comunitários das Resex e foi assumido um valor inicial de $R \$ 4,00 / \mathrm{kg}$ de amêndoa de babaçu. Esse valor inicial não estimulou a venda de amêndoas por parte dos comunitários e foi estipulado um novo valor em conjunto com os extrativistasde $R \$ 5,50 / \mathrm{kg}$ de amêndoa, com base no valor de venda local do óleo de babaçu. Também foi negociada, entre a associação da Resex e o Imaflora, a estruturação de um capital de giro na mini-usina que permitisse 0 pagamento à vista das amêndoas dos extrativistas.

Como comparação, em novembro de 2013 o preço do quilograma de amêndoa de babaçu no Maranhão era de $R \$ 0,96$, enquanto que o preço mínimo sugerido pela Conab (PGPM) era de $R \$ 2,49 / \mathrm{kg}$ (COMPANHIA NACIONAL DE ABASTECIMENTO, 2013). Considerando a produção média de $5 \mathrm{~kg} /$ dia de amêndoa das quebradeiras de coco de babaçu (BRASIL, 2009c), percebe-se que os valores pagos no Maranhão e pelo PGPM resultam em uma diária, respectivamente, de $R \$$ 
5,00 e de $R \$ 12,45$; muito menores do que a diária que tem sido paga pelo comércio local da região da Terra do Meio, de cerca de $R \$ 27,50$. Esse valor ainda está abaixo do valor médio de diária de Altamira e região, de $R \$ 40,00$. Os valores extremamente baixos da amêndoa de babaçu dificultam o desenvolvimento dessa cadeia.

Em 2013 a mini-usina adquiriu o capital de giro e passou a comprar amêndoas, o que aumentou a produção de óleo do Rio Novo. O uso do capital de giro foi mais uma vez acordado em reunião, sendo decidido que o recurso seria administrado pela família responsável pela mini-usina, devendo ser usado, em um primeiro momento, exclusivamente para compra de amêndoas de babaçu para fabricação do óleo. O capital de giro permite a formação de estoque para comercialização de maiores volumes e promove um aumento gradual na formação e organização dos extrativistas para questões logísticas e de pagamento, já que a gestão desse capital é feito pela comunidade em reuniões anuais.

Visando expandir o mercado do óleo de babaçu operado pela mini-usina, houve um esforço de comercialização pelo Imaflora para indústrias cosméticas. Nesse mercado a comercialização do óleo de babaçu não se mostrou simples, pois o óleo é produzido a um preço muito reduzido no Nordeste Brasileiro, como demonstrado, e é facilmente substituído por outros óleos vegetais.

Em 2013 houve uma aproximação maior da empresa Natura com os empreendimentos regionais de óleo vegetal. A Natura é parceira comercial do projeto "Cacau Orgânico", comprando cacau das cooperativas ligadas ao projeto na Transamazônica. Em sua nova estratégia, a empresa divide seus fornecedores em territórios, sendo que o território da Transamazônica e Xingu é visto como um dos territórios prioritários. A Natura tem relações tanto com o ISA quanto com o Imaflora em nível nacional, ocorrendo alguns diálogos de aproximação. Regionalmente a Natura aproximou-se da AASFLOR através do técnico local, buscando a compra de óleo de andiroba. Porém, a relação não se efetivou por dois motivos centrais alegados pelo técnico: qualidade do óleo e a decisão da empresa de não abrir novos 
fornecedores até a estratégia territorial ser implantada.

A estratégia regional da Natura tem como enfoque o fortalecimento dos empreendimentos comunitários já trabalhados pela mesma, através da diversificação da produção e dos produtos entregues. Assim, a empresa e a GIZ (Cooperação Internacional Alemã) firmaram uma Parceria Público Privada (PPP) com o intuito de direcionar a cadeia de óleo de babaçu para as cooperativas do Cacau Orgânico, construindo uma fábrica de pequeno porte no município de Pacajá $-P A$.

As ações da Natura, da GIZ e do projeto Cacau Orgânico pouco dialogaram com as ações já existentes na região para a cadeia de óleos vegetais, o que levou o ISA e o Imaflora a realizarem uma reunião com a Natura. Como desdobramentos dessa reunião, houve a maior aproximação dos agentes locais e regionais dos projetos da Natura e foi considerada a possibilidade dos óleos produzidos pelas mini-usinas serem comercializados pela empresa. Esse processo de negociação deve passar ainda por diferentes estágios, contemplando alguns aspectos: avaliação de estrutura e qualidade, demanda da empresa por outras estruturas formais de comercialização (cooperativa, associação, empresa etc.), levantamento de custos de produção nas Resex; definição de contrato entre a empresa e as associações, entre outros.

\subsubsection{Farinha do Mesocarpo do Babaçu}

A farinha do mesocarpo do babaçu é um produto específico do coco babaçu que pode ser utilizado para a produção de mingaus, bolos, pães e massas. $O$ valor de $R \$ 12,00 / \mathrm{kg}$ praticado localmente é um valor que remunera bem os extrativistas, pelo fato de seu processamento ser mais produtivo que o óleo. Até 2013 a farinha de babaçu produzida na mini-usina do Rio Novo era vendida localmente ou em 
Altamira.

Há um grande potencial de inserção do mesocarpo na merenda das escolas de Altamira, das Resex e das Terras Indígenas através do Programa Nacional de Alimentação Escolar (PNAE). Esse potencial foi levantado e discutido nas oficinas e discussões realizadas pelo grupo de políticas públicas do GT de Atividades Produtivas.

Um dos principais gargalos enfrentados pelos extrativistas e instituições para que isso possa se tornar realidade foi a falta da Declaração de Aptidão ao Pronaf (DAP), documento necessário para o acesso ao PNAE que foi aprovado apenas em 2014, estando ainda em fase de implementação entre os comunitários das Resex.

Apesar da falta de documentação, as oficinas e atividades das instituições geraram relações importantes dentro da secretaria de educação da prefeitura de Altamira, com diferentes desdobramentos para viabilizar a inserção do mesocarpo na merenda. Foram realizados estudos nutricionais do produto e o teste de aceitabilidade nas escolas de Altamira, sendo o mesocarpo aceito pela nutricionista responsável e pelas crianças que participaram do teste. É prevista a estruturação da parceria com a prefeitura para 2014.

\subsubsection{Castanha do Pará}

Em 2013 o comerciante de Altamira que já comprava óleo e mesocarpo de babaçu demandou aos comunitários do Rio Novo amêndoas desidratadas de castanha da Amazônia. Essa demanda desencadeou a estruturação de um processo simples de beneficiamento para atender à demanda local, que contemplasse as possibilidades da comunidade e o baixo custo de replicação. Foram instalados quatro quebradores manuais, panela de pressão e um desidratador à lenha. Foram aproveitadas as estruturas e equipamentos já utilizados pelos processos dos óleos 
vegetais e da farinha de mesocarpo de forma que o investimento adicional para 0 processamento da castanha foi de aproximadamente $\mathrm{R} \$ 5.000,00$.

Ao contrário do óleo de babaçu os valores praticados pela castanha conseguem remunerar os diferentes extrativistas envolvidos no processo com 0 valor da diária local. Toda a castanha produzida em 2013 na mini-usina foi comercializada em Altamira a um valor de $R \$ 25,00 / \mathrm{kg}$, sendo que o custo de produção foi de aproximadamente $R \$ 16,00 / \mathrm{kg}$. Nas reuniões realizadas com a comunidade foram feitos acordos de gestão e de utilização do lucro obtido com o processo. Optou-se pela destinação deste recurso para a melhoria dos equipamentos e do processo produtivo.

A implantação do processamento da castanha contou com forte atuação da comunidade em todos os passos, sendo realizadas reuniões constantes para a definição de valores, procedimentos e responsabilidades. Assim, como no processamento do óleo e do mesocarpo, a operação do processo da castanha é realizada pelas famílias, com divisão de papéis. A gestão dos recursos e o controle da produção são realizados pelas filhas da família, enquanto que os pais se responsabilizam pela qualidade do processo e do produto, pela dinâmica de funcionamento e pela relação com comunitários, clientes e representantes institucionais.

Em 2014 foram realizadas melhorias nos processos produtivos, deixando os mesmos mais adequados aos requisitos da vigilância sanitária municipal, melhorando também a qualidade do produto final. O Imaflora desenvolveu rótulos e embalagens específicos para a castanha das Resex, permitindo que a mesma entrasse no mercado formal, já corrigindo as falhas cometidas nos rótulos do óleo e farinha do babaçu.

O processamento da castanha vem ocorrendo de forma complementar ao processamento do óleo e mesocarpo de babaçu e das atividades de roça e pesca. $O$ beneficiamento das amêndoas pode ocorrer de forma intermitente, não sendo 
necessário processar todo o lote de uma única vez. Essa flexibilidade permite aos comunitários a variação de produtos, viabilizandoo uso múltiplo da floresta e uma maior segurança de recursos. 


\section{Análise da Rede Terra do Meio}

\subsection{Evolução e Ciclo de Vida da Rede}

Analisando a situação atual do GT de Atividades Produtivas e das cadeias de valor de PFNM com relação ao ciclo de vida de redes, observa-se que o GT é uma organização recente que pode ser entendida na transição da fase de formação para a fase de maturidade em um ciclo de vida de redes de cooperação (CAMARINHAMATOS; AFSARMANESH, 2008).

Apesar da compreensão da maturidade de uma rede de cooperação não estar clara na literatura, essa consideração se respalda na comparação dos processos desenvolvidos na rede com relação ao modelo estruturado por Gerolamo (2007): i) há mobilização e relação entre as partes interessadas com fortes antecedentes históricos de cooperação; ii) existe um plano coletivo que apóia a cooperação e coordenação das ações na cadeia de valor; iii) há espaços democráticos, reuniões freqüentes e ações conjuntas que fortalecem os laços e relações interinstitucionais; e iv) existem princípios e acordos que norteiam o processo de cooperação.

Por outro lado destacam-se alguns aspectos que podem ainda promover a maturidade da rede, como: i) a estruturação de uma forma clara de participação dos extrativistas nos processos de planejamento, ação e monitoramento dentro do GT; e ii) o aumento do entendimento dos papéis institucionais, formas de ação e funcionamento das redes e cadeias. Apesar do funcionamento da rede e os papéis desempenhados pelos atores ser algo mutável, acredita-se que esse entendimento apoiaria o processo de cooperação e sua melhoria ao longo do tempo.

Analisando o início da Rede Terra do Meio, percebe-se que a rede parte da cooperação já existente e de uma base de ações conjuntas entre instituições da sociedade civil e do governo para a criação e implantação das Unidades de 
Conservação da Terra do Meio. As diferentes ações realizadas conjuntamente antes e depois da criação da rede foram fundamentais, assim como apontado por Schuh e Wegehaupt (2004), para se adquirir experiência e confiança na rede. Esse caminho permitiu a consolidação e/ou desestruturação de laços organizacionais de forma natural, sem aproximações forçadas e sem grandes constrangimentos em momentos de conflitos e desacordos.

Evidencia-se no início do processo de cooperação a participação mais ativa de poucos atores, que assumiram papéis de liderança, motivação e mobilização das diferentes partes interessadas (extrativistas, instituições governamentais e não governamentais e empresas), como observado por Sölvell (2009) para iniciativas de cluster industriais.

A participação dos extrativistas nos primeiros encontros da RTM e do GT de Atividades Produtivas ocorreu com variação de representantes, sem uma estrutura clara de envolvimento dos mesmos e com dificuldade de inserí-los na grande quantidade de informações apresentadas nessas reuniões. Ficou evidente, ao longo dos anos, o desafio de conciliar técnicos, extrativistas e empresas, principalmente pelas diferenças de entendimento, linguagem e ritmo. Isso levou a diferentes ações de formação que reduzissem o processo de exclusão participativa das populações tradicionais, evidenciado por Guerrero, Torres e Camargo (2011). Segundo esses autores os cronogramas de execução dos trabalhos previstos nas unidades de conservação são incompatíveis com o ritmo da população local. Destacam-se entre essas ações de formação:

- o curso de gestão territorial, que além de ampliar o entendimento sobre o território possibilitou o aprofundamento dos participantes em processos de leitura, escrita e matemática;

- o aumento e melhoria do acompanhamento técnico mais estruturado em campo e na cidade, dado pelas instituições de apoio;

- o fortalecimento, acompanhamento técnico e regularização das associações; 
- a ampliação de empreendimentos com gestão comunitária (mini-usina de PFNM do Rio Novo, capital de giro e as cantinas da copaíba, borracha e castanha);

- a participação das associações no PDRS Xingu, aumentando o entendimento dos representantes sobre a política regional, a captação de recursos diretamente pelas associações e a articulação direta com um número maior de instituições; e,

- o aumento do acesso das populações à assistência social do estado com melhorias principalmente na saúde e educação), passando as Resex a contar com escolas (vinte nas três Resex) e postos de saúde (um por Resex).

Da mesma maneira a participação dos demais elos das cadeias (empresas e atravessadores locais) ocorreu através de reuniões e levantamentos pontuais das organizações, buscando a estruturação de parcerias iniciais, ganho de relação e confiança para posterior aproximação das discussões da rede.

Os Grupos de Trabalho da Terra do Meio surgem, também, de forma espontânea, partindo dos processos de cooperação já existentes e da necessidade de aprofundamento e maior cooperação em processos específicos. Esses grupos, vinculados à rede, desenvolveram processos próprios de organização e ação dentro dos respectivos temas.

O GT de Atividades Produtivas, enfoque da pesquisa, reúne os principais atores interessados nas cadeias de valor de PFNM da Terra do Meio. As experiências acumuladas com as cadeias de valor e nos diferentes estudos proporcionaram o amadurecimento e mudanças na governança do grupo ao longo do tempo. Isso resultou em novos processos de cooperação promovidos pelas diferentes parcerias estabelecidas, proporcionando também mudanças na organização dos extrativistas para a comercialização, nas associações das Resex e na organização das instituições de apoio em rede.

Essa mudança na cooperação é resultado do amadurecimento das ações e 
dos espaços de formação estruturados. Esses diferentes espaços estão possibiltando a formação de agentes comunitários mais preparados para a negociação com a sociedade envolvente, aumentando o protagonismo das Resex nas discussões e tomada de decisão. Isso tem viabilizado uma participação mais estruturada de representantes das comunidades nos espaços de planejamento regionais, seja na RTM, seja nos GTs, nas Associações ou no PDRS Xingu.

É importante destacar também o impacto do PDRS Xingu na RTM. O PDRS Xingu por ser um espaço de governança regional, que mobiliza uma quantidade maior de atores e recursos, aparenta ter diminuído a importância da RTM na dinâmica regional. Assim, é provável que a RTM sofra um processo de reavaliação, reestruturação ou mesmo de dissolução.

Dessa maneira, observa-se que o comportamento da rede e subredes da Terra do Meio, direcionadas para as cadeias de valor de PFNM seguem um ciclo de vida similar às redes de cooperação empresarias. A organização da rede é processual e mutável ao longo dos anos, principalmente com o amadurecimento das relações e com o ganho de experiência dos diferentes atores. Um processo iniciado com pouca participação das comunidades está se direcionando aos poucos para um processo de maior autonomia, que demanda tempo e investimento para se concretizar e cumprir os objetivos mais amplos de governança do território e melhoria das cadeias.

\subsection{Estrutura de Governança e Coordenação da RTM}

A Rede Terra do Meio pode ser considerada, de acordo com Camarinha Matos e Afsarmanesh (2008), como uma rede estratégica de longo prazo, autonoma, horizontal, orientada para o desenvolvimento territorial, dividida em subredes.

O GT de Atividades Produtivas pode ser entendido como uma subrede da 
RTM, com orientação estratégica de longo prazo, horizontal, autonoma, orientada pelo tema atividades produtivas no território da Terra do Meio e também dividida em subredes de melhoria e de operação das cadeias de valor.

A RTM e o GT de Atividades Produtivas podem ser entendidos como ambientes destinados à criação de processos de cooperação, similares às organizações de redes colaborativas e ambientes de colaboração estudados por Plisson et al. (2007) e Camarinha-Matos e Afsarmanesh (2008). Esse ambiente proporcionado pela RTM e pelo GT facilitou processos de planejamento e coordenação que ocorreram, em um primeiro momento, entre instituições de apoio e governo e, com o amadurecimento da cooperação, entre esses e as comunidades, os operadores da cadeia e as organizações de mercado.

As subredes são organizações ligadas às redes mais amplas de cooperação, que visam estruturar cadeias ou executar ações específicas (PROVAN; FISH; SYDOW, 2007). Essas subredes, como são os prórios GTs dentro da RTM, possuem o papel de aprofundar temas, realizar planejamentos e estruturar as cadeias. Como exemplo, pode-se citar a formação de três importantes subredes dentro do GT de atividades produtivas, com enfoque principal em: i) políticas públicas para inserção de produtos em mercados institucionais; ii) estruturação, organização e monitoramento das cadeias de valor junto às comunidades; iii) desenvolvimento de mercado para os produtos extrativistas da Terra do Meio.

Analisando as subredes direcionadas para as cadeias de valor observa-se uma estrutura comum de organização. Essas são, normalmente, organizadas pelo tripé "redes/grupos extrativistas" - "instituições de apoio" - "organizações de mercado". As "redes extrativistas" são constituídas por diferentes famílias autônomas, que se conectam através de relações de reciprocidade, de parentesco e compadrio e, na cadeia de valor, através dos regatões e cantineiros. As "instituições de apoio" são formadas pelas organizações governamentais e não governamentais que atuam diretamente com as populações. As "organizações de mercado" são formadas por empresas ligadas à cadeia de valor, incluindo comerciantes e atravessadores; por 
instituições civis, no caso de doação simultânea (PAA doação simultânea); e pela prefeitura, no caso da merenda regionalizada (PNAE). Esse tripé de atuação garante maior qualidade de laços, transparência, monitoramento, balanço de força e confiança para a estruturação da subrede.

Vale destacar que nesse tripé o processo de cooperação e ganho de confiança com os extrativistas ocorre principalmente através das atividades realizadas diretamente com as famílias nas Resex, nas relações diretas instituídas e com os resultados das ações dentro de um processo de melhoria. Somente reuniões em processos participativos de discussão e decisão não garantem a formação das relações de confiança necessárias para o entendimento e atuação conjunta.

Percebe-se, no GT de Atividades Produtivas, que embora não se tenha realizado dentro do processo de planejamento um alinhamento direto quanto aos papéis institucionais, ação importante para a dimensão estrutural da rede (CAMARINHA-MATOS; AFSARMANESH, 2008), o papel dos atores nas subredes é direcionado pelas ações conjuntas, pelo enfoque institucional e pelos conflitos ocorridos. Uma síntese dos diferentes papéis desempenhados pelos principais atores nas cadeias de valor e do GT de Atividades Produtivas da Terra do Meio são descritos a seguir:

- Associações Comunitárias: As principais associações vinculadas às cadeias de valor são: Associação dos Moradores da Resex Riozinho do Anfrísio (Amora), Associação dos Moradores da Resex Rio Iriri (Amoreri), Associação dos Moradores da Resex Médio Xingu (Amomex), Associação Agroextrativista Sementes da Floresta (AASFLOR) e a Associação Extrativista do Rio Iriri e Maribel (AERIM). O papel das associações comunitárias é principalmente 0 de representar politicamente seus associados, a luta por direitos sociais, a busca por melhorias, financiamentos e parcerias. Estão sendo realizadas adequações nos estatutos das associações para que as mesmas possam comercializar os 
produtos das Resex nos diferentes mercados trabalhados Em termos das cadeias extrativistas, as associações possuem o papel de atuar em:

- Negociação de contratos técnicos e comerciais;

- Monitoramento da cadeia;

- Busca de financiamentos;

- Proposição e execução de projetos de melhoria para as cadeias: comunicação, transporte, beneficiamento e acesso a políticas públicas;

- Participação nos processos de planejamento;

- Organização comunitária;

- Extrativistas: Os extrativistas são os operadores diretos das cadeias, organizados em suas respectivas famílias, vizinhanças, comunidades e associações. O papel principal dos extrativistas na cadeia envolve:

- Garantir o bom manejo dos PFNM e sua qualidade (planejamento, coleta, boas práticas, armazenamento);

- Negociação com parceiros comerciais, visando o diálogo sobre os princípios do contrato, valores, qualidade, operacionalização da cadeia etc.;

- Comercialização da produção localmente;

- Participação nos processos de planejamento;

- Participação de reuniões comunitárias, especialmente sobre o funcionamento das safras anuais.

- Cantineiros das cadeias da Castanha, Borracha, Óleos Vegetais e Copaíba: são extrativistas responsáveis pela promoção local das cadeias de valor e operação do capital de giro via cantina. O papel do cantineiro é:

- Agregação e controle da produção (recepção, anotações, organização dos lotes, rastreabilidade);

- Gestão de fundo rotativo/cantina (com a compra e venda de mercadorias, compra da produção, pagamento em dinheiro); 
- Gestão da comercialização e parceria comercial (emissão de nota fiscal, negociação, despacho);

- Verificação da qualidade;

- Organização do transporte para Altamira;

- Emissão de nota fiscal (através da nota fiscal de produtor rural, emitindo a nota em nome do grupo de extrativistas e produto que o mesmo representa);

- Participação de reuniões comunitárias, especialmente sobre o funcionamento das safras anuais.

- Organizações de mercado: De maneira geral o papel das organizações de mercado (empresas, comerciantes locais, prefeitura etc.) é:

- Negociar de maneira transparente e justa a comercialização dos PFNM;

- Desenvolver e transferir tecnologias adequadas à realidade extrativista;

- Buscar entender a dinâmica de funcionamento da organização extrativista e buscar soluções técnicas para as dificuldades nos processos de comercialização;

- Disponibilizar informações quanto à qualidade dos produtos.

- Instituto Socioambiental (ISA): O ISA tem um papel central nos processos de produção e comercialização de PFNM na região, tanto na mobilização da RTM e do GT quanto na operacionalização das cadeias de valor. Os papéis do ISA são:

- Assistência técnica - que inclui assistências diretas aos extrativistas no manejo e implantação de melhorias; no suporte à gestão das associações; envolvendo projetos, finanças, organização social, reuniões em espaços políticos, reuniões com empresas; escrita de projetos; operação logística e comercial (emissão de nota, retirada de documentação, controle financeiro). 
- Busca de financiamentos;

- Organização de parcerias técnico/científicas;

- Busca e gestão de parcerias comerciais;

- Implantação de melhorias - tanto nos processos produtivos, quanto nos sistemas de educação e saúde;

- Organização da RTM - secretaria executiva da rede;

- Participação nas reuniões da RTM e GTs;

- Estruturação de processos (de manejo, transporte e comercialização).

- FVPP: A FVPP possui um papelo histórico na mobilização dos agentes locais e externos na criação das UCs da Terra do Meio, possuindo um importante papel político na região da Transamazonica e Xingu. Os papéis assumidos pela FVPP são:

- Assistência técnica em manejo;

- Busca de financiamentos para a melhoria dos processos produtivos;

- Organização da RTM - secretaria executiva da rede

- Participação nas reuniões da RTM e GTs;

- Suporte dentro do sistema político regional especialmente na articulação para acesso a políticas públicas de saúde e educação

- Busca de financiamento;

- Imaflora: O Imaflora assume na região o papel de relação com o mercado e a valorização da produção extrativista da região. Assim, é papel do Imaflora:

- Realização de estudos de mercado;

- Gestão de parcerias comerciais;

- Valorização da produção extrativista (certificação, selos, rótulos, mercados, etc.); 
- Suporte a atividades de campo com: levantamento de custos, técnicas de manejo, apoio ao fundo rotativo e elaboração de materiais didáticos;

- Acompanhamento/monitoramento das cadeias;

- Animação do GT de atividades produtivas e suporte ao desenvolvimento e gestão do plano de ação;

- Participação da reunião da RTM e GT de Atividades Produtivas;

- Busca de financiamentos.

- Instituto Chico Mendes de Conservação da Biodiversidade - ICMBio: O ICMBio possui o papel central de órgão governamental gestor das unidades de conservação, apoiando a gestão compartilhada das Resex, os processos de monitoramento, pesquisa e fiscalização das áreas. Nas cadeias de valor da região o ICMBio possui os seguintes papéis:

- Estruturação dos Planos de Manejo das UCs e acompanhamento/suporte na adequação das atividades realizadas com relação ao mesmo;

- Suporte na adequação das cadeias à legislação vigente;

- Articulação política para a implantação de políticas públicas de forma adequada nas UCs (emissão de Declaração de Aptidão ao Pronaf DAP; suporte ao acesso aos mercados institucionais; etc.);

- Organização da RTM - secretaria executiva da rede;

- Participação das reuniões do GT de atividades produtivas;

- Suporte à organização comunitária (reuniões comunitárias, associação, participação no conselho deliberativo);

- Busca de financiamentos;

- Fundação Nacional do Índio - Funai: A Funai, assim como o ICMBio, possui o papel de órgão governamental responsável pela gestão das Terras.Nas cadeias de valor da região a Funai possui o papel de:

- Apoiar a organização comunitária; 
- Organizar e monitorar a assistência técnica para os processos extrativistas e de subsistência;

- Suporte às associações indígenas;

- Acompanhamento das cadeias de valor da região;

- Participação das reuniões da RTM e GT de atividades produtivas;

- Busca de financiamentos;

- Implantação de melhorias nos processos produtivos.

Para cada subrede o papel dos atores locais pode mudar consideravelmente. Assim, um agente com perfil mais regulador, como o ICMBio, pode desempenhar processos de apoio em uma cadeia de valor, de monitoramento na outra e de fomento em outra. Da mesma forma, instituições com perfil para apoio podem desempenhar, em uma subrede, papel de suporte e monitoramento, não participando ativamente da operação das ações. Assim, é possível dividir os atores da Terra do Meio em: atores de operação das cadeias, atores de regulação, atores de fomento e atores de apoio.

Os atores de operação normalmente dependem das cadeias para gerar seus recursos, executando processos diretos de funcionamento, tais como: compra de insumos, extração, beneficiamento, transporte, comercialização etc. Consideram-se atores de operação os extrativistas, empresas (atacadista, varejista, beneficiadores etc.) e atravessadores (regatões, comerciantes etc.).

Os atores de regulação das cadeias são aqueles responsáveis por definir leis, padrões, critérios, procedimentos e controles. São responsáveis pelos processos de criação de padrões legais e de monitoramento dos mesmos. Normalmente, esses atores são organizações do governo que regulam territórios, processos de extração, processos de comercialização, transações, processos produtivos entre outros. Algumas organizações governamentais de regulação das cadeias de PFNM são: MMA, MDA, MDS, Ibama, ICMBio, Funai, Incra etc.

Os atores de fomento são aqueles responsáveis pelos processos de 
financiamento da cadeia. Esses fomentos podem ocorrer em forma de crédito, financiamento de organizações de apoio, financiamento de projetos, financiamento de safra, subsídios etc. Esse papel pode ser assumido por diferentes organizações, tais como: bancos, fundos, ONGs, Conab, Ideflor, empresas etc.

Os atores de apoio das cadeias são aqueles responsáveis pela assistência técnica, pela promoção de melhorias e inovações e facilitação de processos de cooperação. São responsáveis por treinamentos, apoio à organização social, organização de práticas produtivas, implantação melhorias nos processos produtivos e de beneficiamento, estruturação de parcerias, estruturação de padrões adequados etc. Diferentes organizações podem assumir processos de melhoria das cadeias, sendo: associações comunitárias, organizações de assistência técnica ligada ao governo, ONGs e empresas.

Para as comunidades o entendimento do papel das instituições pode ser ambiguo. Ora a instituição pode ser entendida como um parceiro que as apóia; ora pode ser entendida como Estado com o dever de apoiar em todos os aspectos socioeconomicos; e ora pode ser entendida como o antigo patrão, o qual históricamente prestou assistência às comunidades. Da mesma maneira, verifica-se que há pouco entendimento dos processos de financiamento e captação, o que gera, em alguns casos, desconfiança de que as instituições ou até mesmo a associação comunitária poderiam estar se beneficiando de recursos que deveriam ser diretamente destinados para as Resex.

Esse entendimento e direcionamento dos diferentes deveres do Estado para as organizações mais próximas foi identificado por Le Torneau e Greissing (2010) ao estudar a relação da Natura com a Reserva de Desenvolvimento Sustentável (RDS) Iratapuru no Amapá. Nesse contexto tanto as comunidades quanto o próprio governo ficaram na expectativa que o parceiro comercial realizasse as obrigações do Estado.

Analisando esse entendimento das comunidades, observam-se alguns fatores 
que podem levar a essa expectativa: o isolamento histórico das comunidades dos processos políticos e de seus direitos; a pequena rede de relações externas que as comunidades geralmente possuem; as diferentes visões de mundo existentes; e as relações prévias entre as comunidades e a sociedade envolvente (relações com os seringalistas, regatões, organizações governamentais, grileiros, madeireiros e políticos).

No entanto, percebe-se que o entendimento dos papéis organizacionais varia de acordo com o envolvimento dos comunitários nos processos. Aqueles que participam ativamente da operação das cadeias (cantineiros), de reuniões do conselho, de reuniões da comunidade e do curso de gestão territorial têm maior possibilidade de entender de forma mais abrangente os papéis, ações e interesses dos agentes externos, conseguindo negociar melhor com as organizações.

Assim, percebe-se que a governança e coordenação da RTM e das cadeias de valor de PFNM a ela associada passa por subdivisões autônomas da rede direcionadas para o aprofundamento e implantação de ações. Essas subdivisões, apesar de autônomas em sua organização, são monitoradas e suportadas pelas instituições participantes da rede. Esse processo faz com que as cadeias, apoiadas por subredes de operação, sejam monitoradas e suportadas pelo GT de Atividades Produtivas e suas instituições e também pelo conjunto mais amplo de instituições participantes da RTM. O funcionamento da rede é analisado no Item 4.3 a seguir.

A Figura 15 sistematiza essa estrutura de governança da Rede Terra do Meio, com suas diferentes subredes (os GTs) destacados em marrom, as linhas de ação do GT de Atividades Produtivas em vermelho e os diferentes nós/elos responsáveis pela operação das cadeias destacados em azul, como: as cantinas (C), os extrativistas (reunidos em suas associações), o ISA (como principal instituição de apoio nessa operação) e o mercado. 


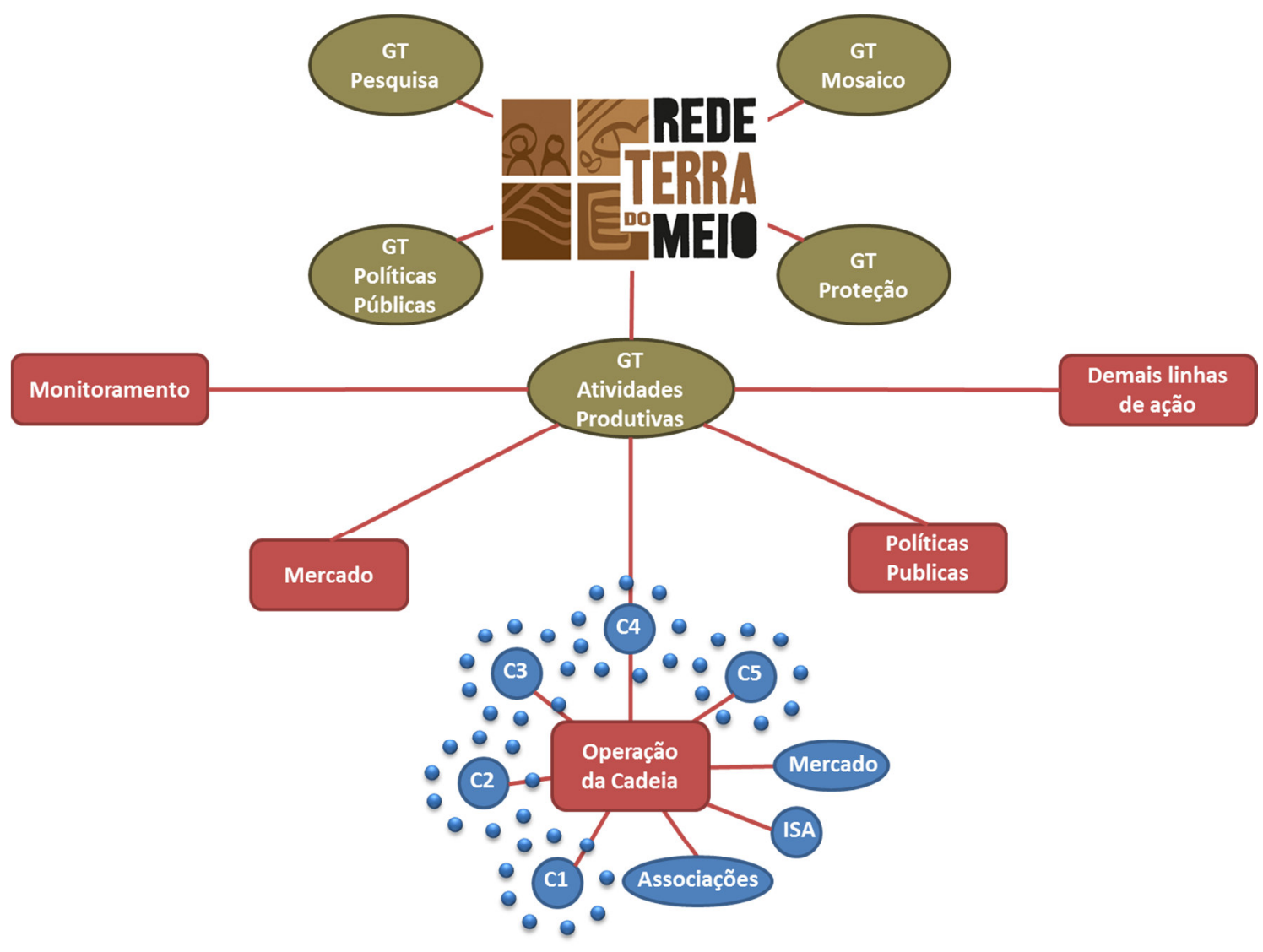

Figura 15: Estrutura de Governança das redes e cadeias de valor da Terra do Meio.

\subsection{Funcionamento da rede e das subredes da Terra do Meio}

De acordo com Camarinha-Matos e Afsarmanesh (2008) a dimensão funcional da rede é relativa à base de operações da mesma, seus processos, fluxos, planos, formas de execução e metodologias. Analisando o funcionamento da rede e subredes da Terra do Meio percebem-se dinâmicas diferentes, paralelas e complementares de funcionamento. A análise foi dividida no funcionamento das subredes de operação e melhoria e em análises de aspectos ligados ao funcionamento do GT de Atividades Produtivas e RTM: orientação estratégica, centralidade, disponibilidade de recursos e resolução de conflitos. 


\section{Subredes de melhoria e operação}

As subredes de melhoria e operação são processos de cooperação mais constantes, que nos últimos anos se conectaram a novas formas de organização, como a cantina e a mini-usina. Nas cadeias da borracha, castanha, copaíba e óleos vegetais a relação entre as instituições de apoio, os cantineiros e os extrativistas é constante.

A atuação dos técnicos de campo evoluiu com a estruturação das cantinas, deixando de ser uma atuação muito focada nos extrativistas e na viabilização da safra, para uma dinâmica de acompanhamento, monitoramento e melhoria de processos. Os técnicos do ISA desenvolveram uma dinâmica em 2014 de acompanhamento, monitoramento e formação que envolve visitas a todas as localidades e acompanhamentos mais profundos aos cantineiros e coordenadores da mini-usina. Esses processos buscam desenvolver as habilidades de gestão e governança necessárias para o bom funcionamento das cadeias como apontado por Morsello (2006), Te Velde et al. (2006), Ros-Tonen et al. (2008) e Pokorny et al. (2012).

Os processos executados pelos cantineiros em conjunto com o ISA são:

- Reunião com o grupo de extrativistas ligado à cantina para a definição de preços da mercadoria, avaliação do funcionamento da cantina e acordos de funcionamento da safra (medidas, perdas, qualidade etc.);

- Compra da produção e análise de qualidade do produto;

- Comercialização da mercadoria a troco pelo produto entregue;

- Gestão do capital de giro;

- Emissão de recibos e controle da produção;

- Avaliação do manejo de alguns produtos (inicialmente da borracha e copaíba);

- Acompanhamento do transporte da produção para Altamira; 
- Estruturação de lista de mercadorias a serem compradas para abastecer as cantinas;

- Comercialização e emissão de nota fiscal em Altamira;

- Negociação com representantes do mercado.

Alguns desses processos são executados quase que totalmente pelo ISA, especialmente os processos realizados em Altamira (compra de mercadoria, emissão de nota fiscal, controle e pagamento de impostos, despacho etc.). Essa execução pode ser entendida de duas formas distintas e aparentemente conflitantes entre si: assistencialismo ou ganho de autonomia processual.

O entendimento de uma ação assistencialista, apontada por algumas instituições locais, ocorre pela visão de que os processos operados pelos comunitários devem ocorrer logo de início de forma autônoma e independente, com ganho de autonomia a partir de processos de formação. Parte-se do pressuposto que os extrativistas já estariam preparados para assumir papéis antes desconhecidos.

A busca por um processo que já se inicia praticamente sem assistência pôde ser acompanhado na implantação da Oficina Cabocla da Resex Riozinho do Anfrísio realizada pela parceria Ipam e ICMBio. A partir dos treinamentos realizados e da instalação da infraestrutura necessária os extrativistas ficaram totalmente responsáveis pela produção e comercialização dos pequenos móveis. A primeira produção foi totalmente comercializada para membros das instituições da RTM. Após essa fase não houve mais acompanhamento técnico na gestão da oficina e no apoio aos processos de produção e comercialização. Mesmo com encomendas já realizadas e uma demanda crescente no mercado de Altamira, principalmente pela vinda de pessoas de outros estados para a construção da UHE Belo Monte, a produção de pequenos móveis diminuiu, resultando praticamente no abandono da atividade ao longo do tempo.

Já o entendimento de ganho processual de autonomia, tem uma visão de 
processo e de aprendizado contínuo na prática para o ganho de autonomia, entendendo que a autonomia ocorrerá ao longo do tempo, de acordo com o ganho de novas habilidades importantes para lidar com a sociedade envolvente e com a garantia da continuidade dos processos iniciados. O entendimento e alinhamento quanto a essas diferentes visões ainda não é claro na RTM, gerando ou potencializando conflitos. Assim, torna-se cada vez mais importante um novo processo de alinhamento quanto a estratégias de ação para o bom funcionamento das parcerias e processos de cooperação. Dado o contexto local é necessário, de forma complementar ao apontado por Gerolamo et al. (2008) e Camarinha-Matos e Afsarmanesh (2008), o alinhamento constante quanto a princípios e estratégias de atuação na cadeia e populações.

De maneira similar ao funcionamento das principais cadeias de PFNM, a subrede de políticas públicas está estruturando projetos entre as associações e a prefeitura de Altamira para entrega de produtos regionais nas escolas das Resex. Nesse processo o tripé de atuação da subrede é composto principalmente pelo ICMBio e Funai, com acompanhamento do ISA e do Imaflora, secretaria de educação da prefeitura de Altamira e associações comunitárias. O acesso ao mercado institucional demandará igualmente melhorias na organização comunitária e acompanhamento técnico constante para seu amadurecimento e funcionamento no longo prazo.

A subrede de valorização dos produtos extrativistas para diferentes mercados tem um funcionamento paralelo às demais subredes. Essa subrede possui duas linhas gerais de ação: i) desenvolvimento e gestão de parcerias; e ii) desenvolvimento e implantação de ferramentas de valorização das cadeias de PFNM.

O desenvolvimento e gestão de parcerias estão centrados especialmente no ISA e no Imaflora, com acompanhamento das demais instituições e transferência gradual de processos para os cantineiros e associações. Esse processo de desenvolvimento de mercado satisfaz o papel de broker da parceria comercial 
apontado por Morsello (2006) e Ros-Tonen et al. (2008). O reconhecimento do ISA e do Imaflora como instituições competentes em suas áreas de atuação e a grande rede de relações nacionais e internacionais que essas instituições fazem parte favorece a conexão com organizações do mercado.

O desenvolvimento e implantação de ferramentas de valorização das cadeias de PFNM também são realizados pelo Imaflora e pelo ISA, com maior centralidade no Imaflora. Tanto para o desenvolvimento de mercado quanto para o desenvolvimento de ferramentas a articulação entre as instituições e outras redes mostra-se fundamental para o sucesso das diferentes iniciativas.

\section{Orientação Estratégica}

O processo de planejamento ocorrido no GT de Atividades Produtivas entre 2010 e 2012 trouxe importantes aprendizados para o processo de cooperação. Como apontado por Gerolamo (2008) a identificação dos atores centrais que já possuiam alguma relação e a definição de objetivos estratégicos possibilitaram o direcionamento de ações prioritárias de melhoria a serem implantadas pelas instituições, individualmente ou em ações conjuntas. Essas ações conjuntas geraram resultados positivos, melhorando a eficiência coletiva da rede e também conflitos que passaram a redirecionar as ações e formas de cooperação.

Como resultado do processo de planejamento é possível destacar: os aprendizados gerados pelos momentos de discussão, ampliando o entendimento das pessoas envolvidas sobre as cadeias de valor de PFNM; o aumento do alinhamento institucional com relação às diretrizes e linhas de ação a serem seguidas, com uma primeira divisão de responsabilidades; e a importância de agentes facilitadores para o diálogo e processos de cooperação, especialmente com a mudança do cenário com relação à UHE Belo Monte.

É importante destacar que a existência de um plano não resolveu conflitos e os principais gargalos existentes nas cadeias de valor de PFNM. Porém, o plano apoiou a orientação das ações institucionais e alguns processos de cooperação e 
direcionou ações conjuntas para a melhoria das cadeias de valor. Destaca-se também que o plano não tem um carater obrigatório de relização das ações propostas. O mesmo busca orientar e coordenar as ações das organizações nas cadeias de valor de PFNM. Apesar da não obrigatoridade, percebe-se que as ações na Terra do Meio seguem as propostas planejadas.

Percebe-se também que o plano de ação estruturado tornou-se um documento dinâmico que se modifica anualmente conforme as ações ganham maturidade e as instituições passam a atuar nas linhas orientadoras gerais. A mudança na ação de criação de linhas de crédito adequadas para capital de giro e cantinas é um exemplo da dinamicidade do plano de ação. No primeiro momento de planejamento foi identificada a necessidade de crédito na mão dos extrativistas durante a safra para que os mesmos pudessem realizar suas atividades. Porém, com a prática e as demandas comunitárias foi estruturada a estratégia de cantinas. Essas, por sua vez, também podem vir a sofrer alterações de acordo com o amadurecimento e resultado dos processos.

Outra importante observação na construção e monitoramento do plano de ação no longo prazo é a necessidade da constante apresentação, avaliação e reposicionamento do mesmo para os diferentes parceiros envolvidos. Esse processo de validação e engajamento tem sido importante regionalmente, principalmente pela alta rotatividade de pessoas e instituições, que demandam uma inserção adequada nas diferentes atividades regionais.

Esse processo de mobilização e engajamento constante é mais amplo do que o plano em si, expandindo-se para o processo de cooperação como um todo e para importância de cooperar. O plano torna-se simplesmente o documento que apresenta o caminho que o processo de cooperação está seguindo.

As cantinas, as mini-usinas e a Semana do Extrativismo trouxeram o processo de avaliação, monitoramento e reposicionamento do plano para dentro das comunidades de forma mais estruturada. Antes, a participação nas reuniões do GT 
de Atividades Produtivas e nos processos de planejamento das cadeias era limitada a alguns membros da comunidade que tivessem disponibilidade. Com a criação desses novos espaços de governança das cadeias, os comunitários passaram a participar mais ativamente dos processos de avaliação e reposicionamento das estratégias e ações. A participação comunitária passou a ocorrer da seguinte forma: i) primeiro individualmente com os técnicos de campo; ii) nas reuniões de planejamento de safra das cantinas e mini-usina; iii) na Semana do Extrativismo, que tem a possibilidade de alimentar o GT de Atividades Produtivas com informações mais diretas dos extrativistas, podendo até passar a englobar o GT dentro de sua dinâmica futuramente.

\section{$\underline{\text { Centralidade }}$}

Apesar das relações horizontais na RTM, percebe-se certa centralização em algumas instituições: na FVPP, nos primeiros anos, e no ISA, nos útlimos anos. Sölvell (2009), analisando as diferentes iniciativas de clusters, aponta ser comum no início dos processos de cooperação a centralidade em alguns atores.

A centralidade inicial na FVPP está relacionada à intensa participação da mesma nos processos históricos regionais, à mobilização para a formação das UCs, à luta pelos direitos das populações tradicionais e à grande quantidade de laços e relações da instituição na região da Transamazônica e Xingu.

O ISA, por sua vez, estruturou seu escritório em Altamira em 2007 com diversas atividades em parceria com a FVPP e sempre com o enfoque nas UCs da Terra do Meio. Com o aumento gradativo de recursos, o ISA conseguiu aumentar sua atuação nas Resex, aumentando sua proximidade com as populações, ampliando laços e relações com comunidades, instituições locais, nacionais e internacionais.

Assim, o ISA passou a desempenhar um papel central para a Terra do Meio, enquanto a FVPP continuou desempenhando um papel central para a região da Transamazônica e Xingu. Essa centralidade do ISA é explicada, também, pela 
característica mobilizadora da instituição, pela sua atuação múltipla e propositiva e pelo processo histórico regional, destacando-se: os estudos e suportes para a criação de diferentes áreas protegidas; as atividades contra UHE Belo Monte; e, principalmente, pelas ações de suporte às comunidades (documentação, saúde, transporte, educação, comunicação, regularização fundiária, organização social e formação).

\section{Resolução de Conflitos}

A rotatividade de pessoas, diferença de quantidade e qualidade de ação das diferentes instituições com as comunidades e diferenças de entendimento sobre os processos regionais facilitou o desgaste de algumas relações locais e a potencialização de alguns conflitos. Fearnside (2003) aponta que conflitos de interesse são inerentes aos processos de governança ligada à conservação, sendo fundamentais processos de negociações e gestão de conflitos.

Não foi identificado na RTM e no GT de Atividades Produtivas um método definido e acordado para resolução de conflitos. No entanto, a existência do espaço político, as relações instituídas, o entendimento da necessidade de cooperação, o alinhamento em princípios e os esforços internos para a cooperação contribuem para a gestão dos diferentes conflitos regionais.

A atuação do Imaflora dentro do processo de planejamento foi importante para amenizar conflitos e gerar alinhamento quanto aos caminhos possíveis de atuação e melhoria dentro das cadeias de valor da Terra do Meio. Essa neutralidade e credibilidade facilitou o diálogo com os atores locais durante o planejamento, sendo importante para o alinhamento do plano entre as partes posteriormente, especialmente com o início das obras da UHE Belo Monte.

O papel de facilitador do processo de planejamento e de relação com o mercado realizado pelo Imaflora é similar ao papel de broker apontado por Schuh e Wegehaupt (2004), Camarinha-Matos e Afsarmanesh (2007) e Ros-Tonen et al. (2008) para mobilização, coordenação e monitoramento de processos de 
cooperação. O papel de facilitador é fundamental para fomentar a cooperação, promover o alinhamento e resolver conflitos na rede. Na Terra do Meio esse papel é dinâmico, sendo desempenhado por diferentes atores ao londo do tempo e das subredes.

\subsection{Recursos da Rede}

Schuh e Wegehaupt (2004), Gerolamo et al. (2008) e Camarinha-Matos e Afsarmanesh (2008) destacam a importância de recursos compartilhados ou destinados para o funcionamento da rede. Esses recursos tendem a viabilizar e promover os processos de cooperação, que demandam esforços dos diferentes atores envolvidos.

A RTM e as diferentes subredes, por serem organizações não formais, não contam com financiamentos próprios, sendo esses operados pelas instituições participantes. No caso das cadeias de valor de PFNM, os recursos existentes são geridos pelas instituições e famílias. Para subsidiar uma análise dos recursos disponíveis na rede buscou-se sistematizar alguns recursos tangíveis e intangíveis, levantados no ano de 2014. Dentre esses recursos (humanos, equipamentos, informação etc) é possível citar:

- Recursos físicos: Paióis familiares de boas práticas de castanha; mini-usinas de óleos vegetais;

- Vinte e quatro paióis familiares de boas práticas de castanha construídos e outros trinta e oito alocados em projeto do ICMBio e ISA;

- Mini-usinas de óleos vegetais: existe uma mini-usina na Resex Rio Iriri e outras três mini-usinas nas comunidades da AASFLOR. Outras quatro mini-usinas estão alocadas em projetos das associações (AMORA, 
AMORERI, AERIM, AASFLOR e AMOMEX) no PDRS Xingu e no Fundo Amazônia com suporte do ISA;

- Vinte escolas municipais de ensino fundamental;

- Três postos de saúde;

- Três pistas de pouso;

- Um sistema de internet via Satélite no Riozinho do Anfrísio e outros dois planejados para as demais Resex;

- Quatro barcos comunitários para transporte de produtos e mercadorias;

- Três lanchas para transporte de saúde e reuniões das associações;

- Três polos comunitários com estrutura para serviços públicos e reuniões comunitárias;

- Colaboradores: atuaram diretamente nas cadeias de valor em 2014: 06 pessoas do ISA; 02 pessoas do Imaflora; 01 pessoa da FVPP; 01 pessoa do ICMBio e 06 cantineiros ligados às associações; 03 assessores comunitários das associações. De maneira geral há pelo menos uma pessoa das demais instituições que acompanham os processos e participam da reunião do GT, mas pouco se envolvem nas ações de melhoria e suporte técnico.

- Conhecimento: além do conhecimento presente nas comunidades tradicionais, que precisaria de vários estudos para sistematizar, há um grande conhecimento tácito na experiência da relação dos técnicos com os comunitários e agentes das cadeias. Como conhecimento sistematizado e compartilhado do GT de atividades produtivas destaca-se: Plano de ação interinstitucional, relatórios de custos das cadeias da copaíba, castanha, borracha e babaçu, a cartilha de boas práticas do coco babaçu e manta de borracha, os planos de manejo das Resex, estudos de mercado e os Protocolos Bioculturais das Resex Riozinho do Anfrísio e Rio Iriri.

- Recursos financeiros: as diferentes cadeias extrativistas da região da Terra do Meio funcionam tradicionalmente com financiamentos da empresa para o regatão e desse para o extrativista. As novas atividades de agregação de valor e 
contratos diferenciados ocorrem com financiamentos de fundações, empresas e governo, captado de forma independente pelas instituições, com alguns projetos compartilhados. Os recursos são alocados em projetos de melhoria da qualidade dos produtos, financiamento das reuniões da RTM e do GT de atividades produtivas, na prestação de assistência técnica, no levantamento de informações e custos, na negociação com empresas, intercâmbios e ações de agregação de valor ao produto. Concomitantemente às ações nas cadeias de valor há ações de melhoria em educação e saúde, que viabilizam a melhoria da qualidade de vida dos comunitários de forma complementar a melhoria de renda.

A operação das cadeias nas comunidades está ocorrendo através de capitais de giro estruturados através de doações das empresas e instituições. Até 2014 estão alocados em capitais de giros nas cantinas os seguintes valores:

- Copaíba: R\$12.000,00 com capital doado pela Firmenich;

- Borracha: $\mathrm{R} \$ 25.000,00$ com capital doado pela Mercur e ISA;

- Óleos Vegetais: $R \$ 10.000,00$ com capital doado pelo Imaflora;

- Castanha: $\mathrm{R} \$ 30.000,00$ com capital doado pelo Imaflora e ISA;

Quando comparado a 2006, quando só existia um colaborador do ICMBio lotado na Resex Riozinho do Anfrísio, e poucos colaboradores das demais instituições com dedicação parcial, houve um aumento considerável de recursos destinados para as Reservas Extrativistas da Terra do Meio. Tanto com relação a recursos financeiros, quanto físicos e de conhecimento compartilhado.

O que se percebe é que a captação de recursos pelas diferentes instituições foi fortalecida pelo processo de cooperação, pelo aumento do poder de negociação da rede, pelo ganho de peso político e pelo aumento da credibilidade das ações propostas. A presença de instituições com capacidade de gerenciar grandes projetos e o ganho de relações da rede aumentou a segurança dos financiadores.

Até 2008 as captações eram principalmente direcionadas para as instituições individualmente e para realização de projetos pontuais. A partir de 2009 foram realizadas captações pelas instituições em conjunto ou de forma coordenada para a 
execução de atividades. Algumas captações podem ser listadas:

- Captações conjunta/complementares envolvendo ISA e FVPP para apoio às cadeias de valor de PFNM e para o curso de gestão territorial em 2009;

- Captação coordenada e complementar pelo Imaflora e ISA contemplando ações de planejamento, estudos de agregação de valor para o mercado e apoio na estruturação de relações comerciais em 2009 e 2013;

- Captação das Associações das Resex no PDRS Xingu em articulação com ISA para ações estruturantes nas Resex e entorno em 2012, 2013 e 2014;

- Captação conjunta envolvendo cinco associações da Terra do Meio e entorno, sete associaçõesda cabeceiras Xingu no Mato Grosso, o ISA e o Imaflora pelo Fundo Amazônia gerenciado pelo Banco Nacional de Desenvolvimento Econômico e Social (BNDES) para a Bacia do Xingu em 2014.

\subsection{Influências nas cadeias de PFNM}

Ao longo da história do GT de atividades produtivas ocorreu uma variação de formas de atuação e suporte às cadeias de valor da Terra do Meio. Inicialmente as ações de melhoria focaram a resolução de gargalos operacionais da cadeia, através de pequenos créditos para a safra, assistência técnica e melhorias nos processos de extração, beneficiamento e armazenamento. Essas ações pontuais e as articulações com o mercado local geraram sobreposição de ações, desmotivação dos extrativistas envolvidos e poucos resultados de melhoria nas cadeias.

Com a continuidade do processo de cooperação, as ações passaram a ser mais estratégicas, direcionadas para a cadeia como um todo, incluindo a busca e 0 estabelecimento de parcerias comerciais. Com isso, as ações passaram a ser articuladas com uma demanda mais certa de mercado, especialmente para as cadeias da copaíba, borracha e castanha. 
Essa estratégia de ação é complementar à proposta de Te Velde et al. (2006), para os quais a melhoria das cadeias de PFNM passam pelo fortalecimento dos empreendedores chave das cadeias, com o aumento do controle dos possíveis impactos negativos dos mesmos, buscando liga-los a cadeias de valor que remunerem melhor e exijam distribuição justa dos resultados.

Dessa forma, o processo de cooperação da Terra do Meio aponta para diferentes maneiras de influênciar as cadeias, categorizadas na tese como: i) influência nos processos produtivos primários das cadeias de valor; ii) influência na cadeia local ${ }^{18}$; iii) influência na cadeia como um todo; e iv) operacionalização de processos fragilizados da cadeia local de forma articulada com o mercado;

A influência nos processos produtivos primários das cadeias de valor ocorreu nos primeiros anos e com ações mais pontuais e individuais das instituições de apoio. Foram realizadas melhorias pontuais em processos produtivos como na construção de paióis familiares para a secagem da castanha e mesmo na estruturação de novas cadeias como a cadeia de pequenos móveis (oficinas caboclas). Essas melhorias pontuais não geraram resultados duradouros por não considerarem aspectos importantes das cadeias regionais, tais como disponibilidade de crédito, pagamento imediato, relações pessoais, transporte e relação com o mercado.

As ações que buscaram influenciar a cadeia local e desempenhar ações de monitoramento partiram da mobilização dos atores locais das cadeias para a estruturação e monitoramento de novos acordos. Essas tentativas foram realizadas na cadeia da borracha nos primeiros anos e na cadeia da castanha. Na cadeia da borracha a articulação com comerciantes locais não gerou melhoria de valores e não

18 Entende-se como cadeia local a cadeia que possui relações diretas com o território, especialmente com a extração de insumos, podendo ter seu processamento e comercialização em outros locais. Ex. cadeia da castanha na Terra do Meio. 
foi possível sua continuidade pelo baixo preço do produto pela inviabilidade de implantação do Programa de Garantia de Preço Mínimo. Para a castanha, esse processo também não possibilitou grandes melhoras de preço nos produtos e nem acordos mais formais de comercialização. Porém, a influência na cadeia através da estruturação de capital de giro e cantinas nas comunidades gerou um processo de aumento de preço regional por competição com os atravessadores. Percebe-se que localmente a organização em rede para a comercialização através das cantinas gera um processo de competição com os intermediários que, por precisarem da castanha para atender seus contratos e abastecer as beneficiadoras, aumentam o preço pago para não perder o produto.

O que se observa nas tentativas ocorridas na Terra do Meio na cadeia local é que elas buscaram envolver diretamente os operadores da cadeia ou influenciar sua atuação através do apoio e operação de parte do processo. Não foram tentadas ainda ações de conexão dos operadores locais a cadeias que valorizam relações éticas vinculadas a estruturação de acordos e processos de monitoramento dos mesmos.

Na Terra do Meio ainda estão em andamento ações que buscaram influenciar a cadeia como um todo sem resultados conclusivos sobre as mesmas. Destacam-se duas ações em andamento nesse sentido. A primeira é a organização de um estudo da cadeia da castanha vinculada a ações de articulação com instituições representativas do setor empresarial e empresas de varejo. Busca-se com essa articulação comprovar os efeitos negativos das relações comerciais estruturadas para os extrativistas, principalmente pela grande variação de preço nas safras, e buscar soluções conjuntas para modificar a cadeia como um todo influenciando atores-chave da cadeia. A segunda é a articulação no Estado do Pará para a implantação de políticas públicas direcionadas aos PFNM, buscando criar e adequar políticas estaduais, federais e municipais à realidade e necessidade do setor.

Por último as ações de operacionalização de processos fragilizados têm como premissa ações na cadeia local articuladas com ações com o mercado, com a 
execução de atividades de fomento, apoio técnico, armazenamento e comercialização com o suporte de atores não operacionais. As principais ações realizadas na Terra do Meio nos últimos anos seguiram o processo de articulação com o mercado e suporte técnico na operação de processos fragilizados ou ainda não dominados pelas comunidades. Essa estratégia ou forma de atuação foi desenvolvida pelas experiências com os operadores locais e pela necessidade de influenciar a cadeia a partir de novas parcerias. Porém, para que essas novas parcerias fossem operacionalizadas foi necessário que os atores locais apoiassem a operação de processos em paralelo à organização comunitária e processos de formação. Em 2013 a estratégia de capital de giro e cantinas, iniciada na cadeia da copaíba, difundiu-se para as demais cadeias demandando uma quantidade maior de recursos para o suporte às cadeias gerando melhores resultados e também maiores riscos para o processo de cooperação como um todo.

As diferentes formas de atuação ou estratégias geraram um conjunto de experiências para os extrativistas, instituições e organizações de mercado envolvidas nas cadeias de valor, tais como:

- A construção de protocolos bioculturais com as comunidades, que busca sistematizar como os grupos extrativistas estão organizados;

- O levantamento de custos de produção;

- A aproximação das empresas da realidade das comunidades e vice-versa, visando trazer o entendimento dos gargalos e potencialidades da cooperação;

- A estruturação de contratos de cooperação simplificados;

- A participação das organizações locais de apoio e regulação do território para suporte e monitoramento das relações;

- A estruturação de capital de giro e cantinas.

Esses procedimentos e as ações realizadas pelo GT e pela RTM contemplam parcialmente as características de uma boa relação comercial apontada por RosTonen et al. (2008), sendo: 
i. A existência de contratos e mecanismos que permita negociações com objetivos e condições mais justas;

ii. o "empoderamento" das comunidades locais para superar desníveis de poder e interesses divergentes;

iii. A inclusão de brokers, com uma função de controladores e guardiões da parceria, podendo ser constituído pelo governo e terceiros, tais como universidades e ONGs, intervindo quando necessário e também orientando empresas e comunidades;

iv. Arranjos institucionais equitativos, com boa relação custo-benefício e organização intermediária flexível, capaz de mediar as partes buscando baixos custos de transação;

v. Benefícios suficientes e compartilhados de forma justa, com base em operações economicas viáveis; e,

vi. O estabelecimento de parâmetros de exploração sustentáveis e sistemas apropriados de monitoramento. (ROS-TONEN et al., 2008, p. 1495).

É importante a ponderação de alguns pontos abordados por Ros-Tonen et al. (2008) para a realidade da Terra do Meio. O primeiro ponto é o entendimento que o estabelecimento de arranjos institucionais e relações, o ganho de poder pelas comunidades, o entendimento da repartição de benefícios e mesmo 0 estabelecimento de parâmetros de exploração são atividades processuais que devem ser visualizadas ao longo do tempo das relações em um território e cadeia. Além do tempo, deve-se observar que alguns processos podem ocorrer com agilidade enquanto outros são mais lentos. Além disso, alguns processos podem ser condição para a estruturação de outros, dependendo da realidade.

Nesse sentido, a estruturação de arranjos institucionais e mesmo a inclusão de brokers ocorre, como visto no histórico de cooperação da RTM, a partir de ações conjuntas. Essas ações viabilizam a criação, fortalecimento ou ruptura de laços tanto interinstitucionais quanto entre comunidades e a estruturação de mecanismos não 
necessariamente formais para a gestão de conflitos.

A inclusão de brokers para mediar relações entre as comunidades e as organizações de mercado pode ser potencializada com a organização em rede, pois pode haver participação de organizações de regulação, apoio, operação e fomento. Esse monitoramento mais amplo pode minimizar os riscos, como apontado por Ribeiro F. (2009), de que uma instituição ou pessoas responsáveis pela intermediação/regulação sejam beneficiadas pela parceria.

Essa organização multi-setorial (apoiadores, reguladores, beneficiários) permite um maior balanço de força no processo de negociação da parceria e operação da cadeia. Esse equilíbrio é potencializado com alguns fatores:

- há uma tradução da realidade das comunidades para as empresas e das necessidades da empresa para as comunidades;

- essa tradução e essa mediação podem facilitar a construção de acordos que contemplem a realidade das comunidades;

- as decisões de mudança nas relações comerciais são reguladas por contratos simples e por atores, evitando imposições arbitrárias das empresas, sendo necessário processos de negociação; os riscos podem ser mais bem mapeados e distribuídos, inclusive podendo alguns riscos serem assumidos pelas instituições;

- há maior distribuição das demandas das comunidades entre os diferentes parceiros, aumentando a possibilidades de serem atendidas e evitando que essas recaiam totalmente sobre a relação comercial.

O empoderamento e o ganho de autonomia das comunidades na Terra do Meio vem ocorrendo durante o andamento dos processos. Seja pela operação dos mesmos, pela assistência técnica, pela criação de espaços de negociação com os atores e entre os extrativistas ou pela realização de intercâmbios e formações de lideranças comunitárias. O processo de aprendizado das comunidades na prática é gradual e complementar a formações (escolar, através do curso de gestão territorial 
etc.).

Como observado nas cadeias de valor e nas ações conjuntas dos atores locais o processo de fortalecimento da organização comunitária pode ir além do escopo da cadeia de valor e das relações empresa-comunidade. Esse fortalecimento da organização social extrativista passa pela estruturação de cursos/processos que viabilizem o entendimento das relações políticas com as quais as populações estão envolvidas, os diferentes interesses ligados a seus territórios e recursos, a formação básica em leitura, escrita e matemática, o entendimento das cadeias de valor e de seus gargalos e potencialidades, pelo acesso à documentação e a direitos tais como saúde e educação adequadas, como apontado por Morsello (2006), Te Velde et al. (2006) e Pokorny et al. (2012).

Assim, mais do que simples formações, cursos de associativismo e cooperativismo, o fortalecimento da organização social das comunidades passa por processos mais amplos, difíceis de mensurar e associar somente às cadeias. A existência de processos participativos, como demonstram Guerrero, Torres e Camargo (2011), não garante o aumento de poder, assim como a não participação em algumas reuniões e na tomada de decisão sobre estratégias e financiamentos não implica necessariamente na exclusão e baixo poder de decisão.

Percebe-se também, na Terra do Meio, o aumento das relações entre as comunidades das três Resex, que possuem realidades similares. Esse aumento vem sendo gerado pelos acordos comerciais, pela estruturação de cantinas, pelas reuniões de conselho e das associações, pelo curso de gestão territorial e pelas reuniões do PDRS Xingu. Esse aumento das relações entre extrativistas amplia seu poder na negociação com agentes externos.

Aliado ao aumento das relações internas há um aumento substancial das relações externas pelos espaços políticos regionais. Segundo Maneschy e Klovdahl (2007) a quantidade e a qualidade das ligações e dos canais de comunicação utilizados por comunidades e associações comunitárias são fundamentais para seu 
fortalecimento organizacional.

O arranjo institucional para a comercialização, por sua vez, traz benefícios e riscos para a cadeia. A decisão inicial de não estruturar um arranjo formal trouxe flexibilidade e aprendizado para a operação comercial, pois os entraves burocráticos demandariam maiores esforços de gestão de uma estrutura jurídica (associação, cooperativa ou empresa). Essa estrutura, provavelmente, apresentaria normas pouco adequadas à organização comunitária, aumentaria custos e quantidade de informações novas a serem absorvidas.

A estruturação de mecanismos de relação com o mercado através da inclusão de instituições de apoio, de contratos, protocolos bioculturais, capital de giro e cantinas buscou valorizar as formas de organização das comunidades e reduzir as possíveis perdas, desconexões e trade offs apontados por Morsello (2006), RosTonen et al. (2008) e Le Tourneau e Greissing (2010).

Assim, percebe-se que a organização informal, voluntária e por grupos de afinidade, como ocorre nas cantinas e mini-usina, proporciona uma estrutura de organização leve, que parte da organização social existente e não impõe regras externas e padrões não acordados pelo grupo. Com isso, os extrativistas podem focar mais nas atividades de operação, governança e no aprendizado de novos processos à medida que as demandas são geradas. Essa organização viabiliza, também, a estruturação de processos de monitoramento das cadeias necessários para a melhoria das relações e acordos nas mesmas como apontado por Te Velde et al. (2006).

Por outro lado, esse arranjo institucional tem um custo elevado de operação quando comparado ao arranjo tradicional de atravessadores e comerciantes locais. Esse custo caracteriza-se pela necessidade de formação e acompanhamento constante dos extrativistas e das cantinas, até que os processos sejam bem absorvidos, tanto na governança interna das comunidades quanto na relação com os agentes e burocracias externas. Esse arranjo, por vezes, apresenta-se inadequado 
para a relação com algumas empresas e mesmo para a relação com o governo, que demandam cadastro de pessoa jurídica para os procedimentos de comercialização.

A emissão de nota fiscal de produtor rural pelo cantineiro, por exemplo, demanda dos extrativistas a retirada de documentos, a ida para Altamira, a relação com operadores da Secretaria da Fazenda do Estado do Pará e o entendimento claro de documentações e procedimentos. Demanda, também, a abertura e gestão de conta bancária para receber o pagamento da empresa e o conhecimento para comprar a quantidade de mercadorias correta e separar a quantidade de dinheiro para repor o capital de giro. A distância das comunidades e os custos de transação envolvidos faz com que parte dessas atividades seja realizada por parceiros locais. Essa transferência na realização de algumas atividades só ocorre por haver uma forte relação de confiança e transparência entre as partes envolvidas.

Um risco importante do arranjo estruturado para a Terra do Meio é que os atores já consolidados na operação das cadeias de valor, como o regatão, sejam substituídos pela "rede", por ONGs ou por instituições governamentais que não dependem do sucesso dessas cadeias como apontado por Te Velde et al. (2006). Essa substituição demanda dos novos atores maiores recursos, esforços e envolvimento de longo prazo. A inexperiência, a falta de conhecimento sobre os custos de transação e os salários dos técnicos pode ser proibitiva para o bom funcionamento da cadeia no futuro.

Assim, a mudança de paradigma na comercialização dos PFNM, com a participação de novos atores, gera uma série de custos transacionais inerentes aos objetivos de melhoria da cadeia. Soluções que proporcionem estruturas leves e flexíveis e que reduzam ou dividam melhor os custos transacionais envolvidos nas cadeias produtivas de PFNM ainda devem ser encontradas como já apontado por Ros-Tonen et al. (2008).

Os estudos de custos e as negociações ocorridas entre os atores da cadeia trazem entendimentos e complementações para a viabilidade, governança e 
coordenação das mesmas. Uma análise meramente econômica do extrativismo, como feita por Homma (1992), aponta para a inviabilidade do extrativismo em longo prazo, sendo o mesmo fadado à substituição por monoculturas ou produtos sintéticos. Porém, essa análise, não considera fatores externos às relações econômicas diretas que agregam valor às cadeias, tais como cultura, modo de vida, proteção territorial e serviços socioculturais e ambientais. Quando comparado a uma monocultura percebe-se que o extrativismo: traz poucas mudanças na dinâmica ecológica da floresta; demanda deslocamentos mais longos para acesso aos recursos, o que possibilita maior monitoramento do território; pode agregar múltiplos produtos; e é formado por atividades normalmente já dominadas e que valorizam o modo de vida das populações tradicionais e seus territórios. Sendo assim, os PFNM da Terra do meio têm a eles associado um valor agregado referente a um serviço sociocultural ambiental, por favorecerem a valorização do modo de vida das populações tradicionais e indígenas e, com isso, a conservação da floresta.

O modo de vida, a cultura e o conhecimento das populações são ativos que mantidos e potencializados podem prestar diferentes serviços à sociedade (desenvolvimento de pesquisas, medicamentos, conservação da floresta, água e biodiversidade etc.). Porém, o valor agregado a esses ativos é de difícil mensuração e necessita de métodos e cálculos que apoiem a determinação de seu valor. Para o pagamento desses serviçosassociados aos PFNM é necessária a estruturação de arranjos, contratos e formas de pagamento específicas. Esse valor pode ser pago tanto pela relação comercial quanto direcionado a outros mercados, como o mercado de crédito de carbono, devido ao desmatamento evitado.

\subsection{Considerações finais}

A análise do estudo de caso da RTM feita acima demonstrou que as teorias de redes de cooperação podem ser aplicadas para orientar a estruturação de processos 
de governança multi-stakeholder da floresta e das cadeias de valor de PFNM, uma vez que essas teorias trazem subsídios para: i) organização de ambientes propícios à cooperação, que viabilizam a estruturação de parcerias e processos de monitoramento; ii) organização e coordenação de redes, subredes e cadeias; e iii) organização de estratégias para melhoria e monitoramento das cadeias de valor.

A organização em rede formada na Terra do Meio segue uma estrutura não formalizada, de suporte a processos de cooperação, que se desdobrou em subredes para a operacionalização de melhorias e processos ao longo do tempo. Esses desdobramentos possuem formas de organização e atuação totalmente autônomas com relação à RTM. Porém, suas ações são pautadas nas discussões e planejamentos realizados e seus resultados são monitorados nos diferentes espaços políticos organizados.

$\mathrm{Na}$ Terra do Meio a relação entre redes de instituições de apoio, de governo e de extrativistas ocorre em ambientes e fóruns de cooperação tais como a RTM e o GT de Atividades Produtivas. Desses espaços surgem possibilidades de parcerias para a melhoria do território e para a ação em conjunto com a rede extrativista, que possui padrões de funcionamento historicamente instituídos. As melhorias nas cadeias e na governança do território passam pelo entendimento dos padrões históricos dos grupos extrativistas e da dinâmica existente para a realização de melhorias nos processos.

O processo de cooperação e ganho de confiança entre organizações governamentais, não governamentais, de mercado e extrativistas é fundamental para o bom funcionamento da rede de cooperação e concretização das ações de melhoria nas cadeias produtivas. Somente reuniões e processos participativos de discussão e decisão não garantem a formação das relações de confiança necessárias para o entendimento e atuação conjuntas. Na RTM, o aumento de confiança acontece principalmente através das atividades realizadas diretamente com as famílias nas Resex, nas relações diretas instituídas e com os resultados positivos das ações de melhoria. O contato direto e a aproximação dos extrativistas 
foram fomentados em grande parte através do trabalho nas Resex dos técnicos de campo contratados pelo ISA, que desenvolvem uma dinâmica de acompanhamento, monitoramento e formação da comunidade através de visitas periódicas em todas as localidades.

Em adição, para que as reuniões e tomadas de decisão sejam realmente participativas, é preciso fomentar o profundo discernimento / entendimento dos extrativistas sobre os diferentes pontos de discussão, o que se dá através de cursos de formação e diálogos contínuos que favorecem o empoderamento da comunidade através do acesso à informação. Na RTM, além do trabalho contínuo dos técnicos de campo descrito acima, pode-se ressaltar como exemplos de ações de formação, interação e difusão de informações com os extrativistas: o curso de Gestão Territorial; a Semana do Extrativismo e a participação e auxílio das instituições de apoio nas reuniões das associações das Resex.

Percebeu-se também a partir da análise e participação no GT de Atividades Produtivas da RTM que o envolvimento maior da comunidade com as questões produtivas é estimulado pelo aumento da qualidade de vida dos comunitários, através de ações em educação e saúde, de forma complementar à geração de renda. Dessa forma, a comunidade solicita das instituições de apoio auxílio também nessas questões, o que é feito principalmente através de pressão e ações conjuntas com os órgãos responsáveis para cumprimento de políticas públicas nas Resex, com construção de escolas, postos de saúde e contratação de profissionais habilitados.

Percebe-se, também, no caso das cadeias de valor de PFNM da Terra do Meio, que há um deslocamento da governança da cadeia. Essa sai da exclusividade da empresa para uma governança mais compartilhada, com maior equilíbrio de forças na relação entre empresa, intermediários e comunidade. Essa mudança ocasionada pela cooperação aparenta ter melhorado a comunicação, a definição de padrões de qualidade e preços, regras, contratos e papéis. Assim, o estudo indica que as mudanças nas cadeias de valor podem evoluir de uma perspectiva de 
melhoria baseada na relação empresa-comunidade, como estudado por Morsello (2006), Le Tourneau e Greissing (2010), para uma perspectiva de relação múltipla, demandando uma governança e coordenação em rede e o envolvimento gradual de diferentes operadores das cadeias.

Para complementar as considerações finais do estudo de caso, no quadro abaixo (Quadro 9) é feita uma análise da RTM em comparação aos principais pontos trazidos pela teoria de redes de cooperação e aspectos relacionados ao bom funcionamento das cadeias de valor de PFNM, encontrados na literatura. 
Quadro 9: Síntese da análise do estudo de caso da RTM.

Fatores de análise Terra do Meio

Rede estratégica de longo prazo direcionada para o

desenvolvimento territorial. A

rede se organiza em processos

de cooperação pré-existentes ou

que se formam a partir dos

espaços políticos da RTM e do

GT de Atividades Produtivas,

sendo os mesmos considerados

como fóruns e ambientes de

potencialização de processos de

cooperação interinstitucional.

Laços

Laços múltiplos e horizontais nas

redes e laços múltiplos e mais

interorganizacionais horizontalizados nas cadeias de

nas redes e

cadeias

valor buscando situacão ganha-

ganha para as organizações

participantes.
Literatura

Camarinha-Matos e

Afsramanesh (2008) e

no caso das redes

colaborativas de longo prazo

a importância de ambientes

de cooperação denominados

de Virtual Breeding

Environment (VBE). Esses

ambientes são apontados

pelos autores como

promotores de processos de

cooperação

interinstitucionais.

Ros-Tonen et al. (2008) e Ingram (2014) apontam a necessidade de estruturação de processos de parceria multi-stakeholder para a gestão da floresta e criação de situações ganha-ganha a governança florestal e cadeias de PFNM.
Considerações

A RTM e o GT de Atividades Produtivas realizam o papel de promover prom espaço de diálogo entre as instituiçoes para espaços políticos. Analisando a RTM percebe-se que o funcionamento do ambiente é variável ao longo do tempo, sendo que as instituições buscam aproveitar as oportunidades apresentadas. Não é explicito na literatura a forma de estruturação desses ambientes de cooperação. Observa-se na pesquisa que os mesmos podem ou não ser formalizados, e a não formalização da RTM e GT foi trouxe maior flexibilidade para o começo do processo de cooperação. Porém pode ser demandada organizações formais para a cooperação na cadeia futuramente.

O ambiente institucional da Terra do Meio é condizente com as mudanças na governança florestal apontada por Ros-Tonen et al. (2008), contando com fortes pressões sobre os territórios e populações e um grande número de instituições com interesses diversos. O envolvimento de diferentes atores em ambientes de cooperação se mostrou fundamental para a melhoria das cadeias de valor tanto pelo ganho de força política, quanto pela melhoria na resolução de conflitos, compreensão de processos e coordenação de ações. De forma complementar à proposta de Ros-Tonen et al. (2008), a organização em rede ou fóruns de discussão foi fundamental para a estruturação de parcerias ou subredes de cooperação em diferentes aspectos. Para as cadeias de valor a participação de diferentes atores na parceria comercial possibilitou ganho de confiança e uma relação mais horizontal nos processos de negociação, execução e monitoramento da relação/parceria. 


$\begin{array}{ll} & \begin{array}{l}\text { A estrutura de governança } \\ \text { existente na Terra do Meio é } \\ \text { complexa e dividida em subredes } \\ \text { de cooperação para a realização } \\ \text { de melhorias. As relações nas }\end{array} \\ \text { cadtruturas de } & \begin{array}{l}\text { cadeias de valor são } \\ \text { intermediadas pelas instituições } \\ \text { locais que fazem o papel de } \\ \text { broker dessas relações entre } \\ \text { operadores de mercado e grupos } \\ \text { extrativistas. }\end{array} \\ & \\ & \text { O conjunto de princípios } \\ \text { estruturados no processo de } \\ \text { planejamento do GT foi } \\ \text { importante para balizar o } \\ \text { processo de planejamento e } \\ \text { cooperação entre as instituições. }\end{array}$

A teoria de Redes de

Cooperação consultada

(GEROLAMO et al., 2008; PROVAN; FISH; SYDOW, 2007; CAMARINHA-MATOS: AFSARMANESH, 2008; SCHU; WEGEHAUPT, 2004; SÖLVELL, 2009) indicam que os processos de cooperação interfirmas podem ocorrer com maior coordenação com a governança apoiada por brokers e/ou por uma

Agência de Desenvolvimento Regional (ADR).

Schu e Wegehaupt (2004) e Camarinha-Matos (2008) apontam como fatores de sucesso de cooperação a definição clara de regras, papéis, princípios e diretrizes do processo de cooperação.
A governança da Rede Terra do Meio, no GT de Atividades Produtivas e suas diferentes subredes é dinâmica e encontra-se em construção. A relação dos grupos extrativistas com operadores de mercado é realizada através de brokers como indicado por RosTonen et al. (2008), podendo o mesmo variar de cadeia para cadeia E possível que o papel de broker desempenhado por diferentes atores atualmente seja substituido por uma estrutura de governança da cooperação, como as associações ou uma ADR à medida que os grupos extrativistas ganhem capacidade de gestão e surja necessidade e oportunidade para que uma agência ocupe o papel hoje desempenhado pelas instituições.

Observou-se que o processo de construção de regras, acordos, instrumentos de gestão, papéis e normas é gradual de acordo com o processo de cooperação, sendo essas definições constantemente refeitas ao longo do processo. Observou-se também que a existência de definições mais claras de papéis, princípios e processos pode proporcionar melhorias na cooperação. 
Fatores de análise Terra do Meio

Contratos simples de relação entre elos da cadeia de valor;

Formalização nos processos de cooperação

Centralização

Variabilidade de produtos/cadeias produtor rura e recursos em poucos nós da rede

Cooperação focada em multiprodutos incluindo a manutenção de atividades de
Literatura

Contratos e acordos entre agentes trazem segurança para as relações e parcerias tanto para redes quanto para relações comunidadeempresa (MORSELLO, 2006; ROS-TONEN et al., 2008); simples com emissão de nota de

Centralização de relações, ações subsistência

Uma rede perfeita não teria concentração de poder ou relações. Porém, estudos

dos processos de cooperação interfirmas apontam processos de concentração de poder e relações especialmente no início da cooperação;

Para Morsello (2006), Le Tourneau e Greissing (2010) um dos pontos negativos dos processos de cooperação empresas-comunidades é o enfoque dado em um único
Consideração

Os acordos de cooperação são fundamentais para o alinhamento das instituições e também das relações na cadeia de valor. Os acordos na Terra do Meio foram construídos com base nas relações existentes e possibilitaram aumento da confiança nos processos. De forma complementar à Morsello (2006) observa-se na Terra do Meio um processo de construção desses contratos, que consideram características da organização comunitária e processos claros de negociação.

O processo de centralização em redes de cooperação para PFNM não aparenta ser diferente do processo apontado por Sölvell (2009).

Porem, observa-se que a centralidade e variavel ao longo do tempo e de acordo com a capacidade das instituições de articular com a rede extrativista e com a rede territorial e de acordo com as relações com o ambiente externo. Essa centralidade se distribui também nas subredes de operação de melhorias e processos, pela autonomia dos atores e subredes na execução de suas atividades. O processo de centralização na rede de extrativistas não foi analisado, ocorrendo alguma centralidade nos cantineiros pela sua posição na cadeia de valor e relações pessoais. Esse ponto pode ser pesquisado futuramente. produto na relação.
A estruturação multicadeias da Terra do Meio reduz o risco de pressão sobre um único recurso e mantém a lógica de uso múltiplo da floresta das Populações Tradicionais. Esse processo gera, também, a possibilidade de escolha da atividade e, principalmente, a possibilidade de geração de renda ao longo de todo o ano em paralelo às atividades de subsistência, especialmente roça, caça e pesca. 
Eficiência coletiva ampliada a partir da realização de projetos conjuntos entre os diferentes atores envolvidos, com ganho de Eficiência Coletiva confiança com a realização dessas ações conjuntas. Processo de planejamento compartilhado apoia orientação das ações, coordenação e ganho de eficiência.

Redes recentes e em processo

Ciclo de vida da rede de estruturação, podendo se classificadas em um processo de
Interação entre economias externas e ações coletivas entre os stakeholders, promovendo iniciativas para melhorar a cooperação e competição (SCHMITZ, 1995). Gerolamo (2007) destaca a importância de processos deliberados de governança e coordenação para a melhoria de processos de cooperação.

\section{Camarinha-Matos e}

Afsramanesh (2008) e Söllvel (2009) descrevem o ciclo de vida de redes de cooperação evidenciando as transição entre sua formação para a maturidade.

\section{Consideração}

As ações conjuntas entre instituições de apoio, entre essas instituições e os grupos extrativistas, entre os próprios grupos e entre desses atores com as organizações de mercado foram fundamentais para a formação e fortalecimento da RTM, do GT de Atividades Produtivas e para a estruturação de novas relações nas cadeias de valor. A realização de atividades conjuntas de forma deliberada é fundamental para a construção e/ou desestruturação de laços, para a confiança e para a cooperação na cadeia de valor. Destaca-se essa realização de ações conjuntas como ponto de partida para a construção de processos de cooperação mais amplos e ganho de eficiência coletiva.

A evolução da RTM mostra um processo similar ao apontado pela literatura de redes de cooperação. Tanto as redes mais amplas, como a RTM e o GT de Atividades Produtivas, quanto as subredes de operação e melhoria passarem por esse ciclo, mudarem sua organização e estrutura ou sofrerem processos de declínio e dissolução da cooperação. A dissolução pode ocorrer por diferentes fatores, podendo ser a obtenção do resultado/objetivo almejado pela cooperação, por mudanças no cenário político local, por conflitos entre os atores entre outros. meração;

evolução e melhoria

contínua; Metamorfose, dissolução ou declínio. 
A Rede Terra do Meio e o GT de Atividades Produtivas foram criados inicialmente para promover a cooperação

Envolvimento das populações possibilitaram o aumento gradual da participação efetiva das populações nos ambientes de cooperação e nos processos de operação e monitoramento das cadeias de valor de PFNM.

Variável de acordo com o período de atuação das instituições e cadeia. Para os óleos vegetais há Te Velde et al. (2006) aponta pouca operação voltada à a importancia de realizar comercialização ocorrendo maior melhorias nas cadeias Atuação da rede na suporte na melhoria dos considerando os atores de Cadeia de valor
Te Velde et al. (2006),

Morsello (2006), Ros-Tonen et al. (2008), Pokorny et al. (2012), Le Tourneau e

Greissing (2010) apontam a importância do envolvimento das comunidades nos processos de decisão, planejamento, operação e monitoramento das cadeias e a necessidade de fomenta processos de formação das comunidades em gestão. pressos. Nos últimos anos operaçáo das mesma passou a realizar ações de apontando os riscos de

De forma complementar à literatura o que se observa na Terra do Meio é que a participação da comunidade é dinâmica ao longo do tempo e demanda um esforço para o acesso à políticas públicas e em formação. Quanto maior o preparo da comunidade mais efetiva é a sua participação. Destaca-se a importância de trabalhar nos processos de formação o entendimento da realidade vivenciada no território como um todo além de ferramentas e técnicas de gestão e organização social. Destaca-se que o processo de formação demanda um alto investimento e processos de acompanhamento, não sendo suficientes a realização de cursos pontuais de associativismo e cooperativismo.

Percebe-se que não existe um caminho único de promoção das cadeias de valor de PFNM. Cada cadeia e região passaram por processos históricos diferentes e possuem riscos e oportunidade igualmente distintas considerando as relações na cadeia de valo nas redes. Então, o que se observa é a possibilidade de influenciar as cadeias de diferentes formas de acordo com as oportunidades $e$ melhoria e operação das cadeias substituição dos mesmos po como um todo. Pode sofrer novas atores que não dependem mudanças com ampliação da da cadeia. necessários para cada forma de ação.

comunicação com atores locais

de operação das cadeias. 
Para Pokorny et al. (2012)

acesso a direitos,

principalmente ligados à

A RTM possui uma atuação ampla com relação aos territórios,

Acesso a direitos e proporcionando processos de formação cooperação em diferentes temas relativos ao desenvolvimento territorial.

O monitoramento na Terra do Meio ocorre em diferentes

\section{Estruturas}

transparentes de âmbitos sendo os principais: comunidades; cantinas; monitoramento da acompanhamento institucional cadeia

nas comunidades; reuniões do GT de Atividades Produtivas; RTM documentação, saúde e

educação, são requisitos inerentes à qualidade de vida, trabalho e relações sociais e à capacidade de mudar a realidade das comunidades envolvidas com as cadeias de PFNM.

Te Velde et al. (2006) evidencia a importancia de criação de processos de monitoramento das cadeias considerando os atores envolvidos e as comunidades. Para as redes de cooperação Gerolamos (2007) destaca a importância de se criar processos de medição de desempenho que considerem o processo de cooperação
A estruturação das relações nas cadeias em paralelo à estruturação de processos de cooperação para o desenvolvimento territorial é fundamental para que ocorram melhorias nas cadeias de valor e para que questões sociais não sejam direcionadas para as cadeias como ocorre desde o seringal para as populações da Terra do Meio.

O processo de monitoramento organizado para as cadeias de valor da Terra do Meio possibilitam a avaliação das cadeias pelos diferentes atores envolvidos de forma não estruturada, que é suficiente para o grau de maturidade da rede e das ações até o momento. Com a ampliação dos processos de cooperação e a estruturação de sistemas de certificação, como o selo de origem, será necessária a estruturação de um sistema de indicadores de desempenho que reflitam os resultados das cadeias e da

cooperação no território, nas relações e em suas populações. Esses indicadores possibilitarão, também, o dimensionamento e valoração dos serviços socioambientais prestados pelas populações e seus produtos.

Fonte: Elaborado pelo autor. 
Visando sistematizar o conhecimento adquirido durante os quatro anos de pesquisa na Terra do Meio foram organizadas diretrizes para a estruturação de redes de cooperação voltadas para as cadeias de PFNM apresentadas no Item 5 a seguir. 


\section{Diretrizes para estruturação de redes de cooperação voltadas para as cadeias de PFNM}

Com base nas análises realizadas da experiência da Rede Terra do Meio e na consulta à literatura de Cadeias de PFNM e Redes de Cooperação, foram sistematizadas algumas diretrizes que podem contribuir com processos de cooperação intersetorial para a promoção de cadeias de valor de PFNM. Ressaltase que essa sistematização traz os elementos centrais da análise, não tendo como pretensão ser um modelo que contemple todos os processos e as dinâmicas de relações possíveis em redes de cooperação com enfoque nas cadeias de PFNM.

Entende-se que a cooperação e a coordenação das cadeias/redes podem ocorrer de diferentes maneiras, organizando-se em diferentes arranjos, de forma a responder a uma grande quantidade de questões. Porém, o que se espera é que as diretrizes estruturadas traduzam a experiência regional e colaborem com processos de análise e organização na Terra do Meio e em outras regiões com características similares. A Figura 16 esquematiza um ciclo de diretrizes de governança de redes de cooperação voltadas às cadeias de PFNM.

O ciclo apresentado é baseado no modelo proposto por Gerolamo (2007) e no ciclo de vida de redes de cooperação apresentado por Camarinha-Matos e Afsarmanesh (2008). Dentro dos diferentes processos são considerados aspectos de gestão de redes apresentados por Camarinha-Matos e Afsarmanesh (2008). Os processos de operação, melhoria e monitoramento da cadeia e da cooperação tomam como base as considerações de Morsello (2006), Te Velde et al. (2006) e Ros-Tonen et al. (2008). 


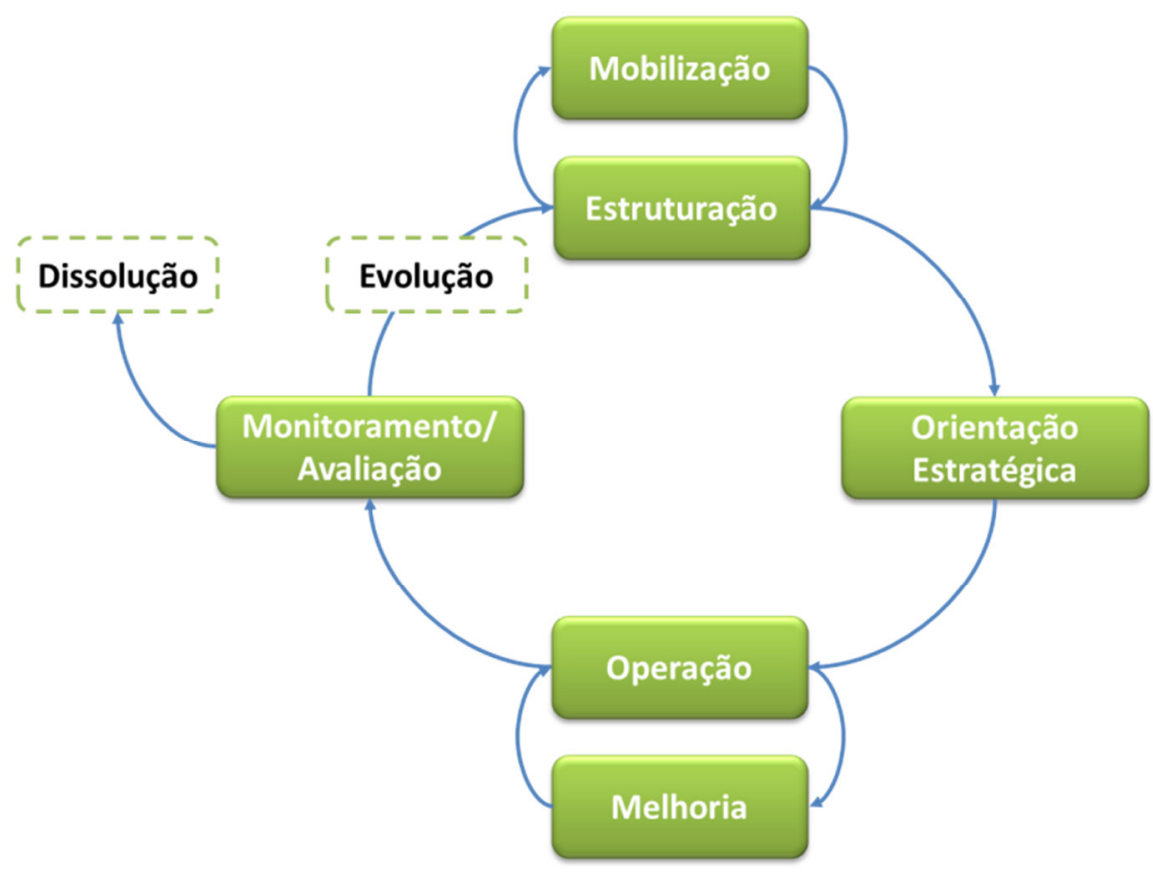

Figura 16: Ciclo de processos de governança de Redes de Cooperação.

Para tornar o processo mais didático, optou-se por iniciar a explanação da estrutura pela mobilização dos atores e estruturação da rede de cooperação.

\subsection{Mobilização e estruturação da rede}

A mobilização dos atores das cadeias de valor pode ser realizada envolvendo todos os atores que desempenham os diferentes papéis na cadeia, ou identificando atores que possuem relações próximas, já realizam atividades em conjunto e dividem alguns princípios. É uma característica das redes a participação voluntária e espontânea de pessoas e organizações, que tendem a ser autônomos em suas decisões, articulações e ações. A mobilização de novos atores pode ocorrer com o ganho de maturidade e aumento da estruturação da rede.

Um processo que envolva inicialmente poucos atores que já possuem um 
relacionamento pode ser entendido como um surgimento espontâneo, "de baixo para cima", da cooperação em rede. Essa formação com atores mais coesos tem maior potencial de alinhamento, organização e continuidade, porém com o risco de perder chances de negociação com outros atores no começo.

Com os atores centrais identificados e mobilizados inicia-se o processo de estruturação da cooperação, o qual visa definir os objetivos centrais da rede, seus princípios e valores, sua organização, quais são os papéis, funções, formas de comunicação, periodicidade de reuniões etc. Por ser tratar de um processo, a estrutura final da rede não é necessariamente definida no início, sendo necessária a experiência para definir as melhores formas de organização da rede, que podem ser mutáveis de acordo com os resultados e dinâmicas locais. Porém, quanto melhor estiverem definidos os acordos, maiores são as possibilidades de resolução de conflitos futuros, naturais dos processos de cooperação.

Conforme apresentado na Figura 16, a estruturação da rede encontra-se ligada ao processo de mobilização em um ciclo contínuo. Isso ocorre pela necessidade observada de constante mobilização e animação dos atores para o processo de cooperação. Essa animação constante é necessária para validar a estrutura definida, os acordos, circular informação, fortalecer laços organizacionais e pessoais e apoiar a resolução de conflitos. A animação da rede pode ser realizada de diferentes maneiras e por diferentes atores, porém a existência de pessoas ou organizações que desempenhem esse papel mostrou-se importante na dinâmica de funcionamento das redes.

Destacam-se alguns pontos a serem observados nos processos de mobilização e estruturação da rede ao longo do tempo, não sendo estes pontos obrigatórios:

- Participação voluntária na rede;

- As pessoas e organizações são autônomas em suas decisões, articulações e atuação na rede; 
- Podem ser definidos os objetivos gerais da rede, seus princípios e valores - a definição dos objetivos, princípios e valores é importante para trazer um alinhamento entre as pessoas participantes sobre a forma de trabalho, os objetivos gerais e o entendimento geral da cooperação;

- Com base nos objetivos, princípios e valores, pode ser definido um documento de acordo geral, um pacto, que transmita os acordos do processo de cooperação;

- A estrutura da rede pode ter subdivisões, como subredes, grupos de trabalho ou parcerias, para a realização de processos específicos;

- A definição de um facilitador da cooperação pode ser importante para facilitar o encontro institucional, buscar recursos para a cooperação, apoiar a resolução de conflitos, apoiar a organização e execução de planos e aumentar o alinhamento institucional quanto aos princípios, valores e objetivos da cooperação;

- É importante que a rede focada na promoção das cadeias de PFNM esteja conectada a outra rede, mais ampla, que contemple os diferentes aspectos de governança das áreas protegidas;

- A estrutura da rede pode ser formal ou informal - a não formalização da rede em termos jurídicos é positiva inicialmente para que haja experimentações de modelos e possibilidades sem a burocracia inerente aos modelos jurídicos existentes e possíveis. Porém, com o tempo, estruturas formais podem ser demandadas para a rede como um todo ou para as subredes formadas para a operação de alguns processos das cadeias, podendo potencializar o processo de cooperação com a criação de infraestruturas e recursos exclusivos da rede.

\subsection{Orientação Estratégica}

$\mathrm{Na}$ estruturação da rede também é necessária a definição de linhas 
estratégicas de ação para orientar o processo de cooperação. Pode ser interessante começar o processo de cooperação com alguns projetos conjuntos, como, por exemplo, de estudos sobre as cadeias, de busca de informações de mercado e com algumas ações práticas, para que a rede ganhe experiência no processo e nas ações conjuntase para que as limitações e oportunidades da cooperação sejam conhecidas. O início da operação de algumas ações conjuntas evidencia a necessidade de orientações estratégicas a serem seguidas pelo grupo, de forma a haver mais coesão no entendimento das cadeias e nos possíveis caminhos para 0 território.

A orientação estratégica possibilita que os atores tenham clareza das possibilidades territoriais, facilitando o processo de planejamento interno de suas atividades e também facilitando a estruturação de parcerias e atividades conjuntas.

A orientação estratégica pode contemplar linhas gerais de atuação e um plano de ação macro, voltado para a rede como um todo, assim como ações a serem realizadas em curto prazo. Os planejamentos de curto prazo visam a análise das ações a serem realizadas no ano, a divisão de atividades por organizações, parcerias ou grupos de trabalho, a divisão de agendas de campo e a estruturação de atividades complementares. Vale destacar que tanto o planejamento de longo prazo quanto o de curto prazo, não prende as instituições à obrigatoriedade de realizar atividades conjuntas, sendo o momento de planejamento focado no alinhamento da rede e na definição de prioridades, que é feita por cada instituição de forma autônoma.

Na prática o processo de planejamento ocorre periodicamente e de acordo com a necessidade de alinhamento dos atores locais e das mudanças que venham a ocorrer nos cenários analisados. A mudança constante de pessoas nas instituições da região amazônica, por exemplo, demanda um processo de alinhamento constante, sendo importante o resgate periódico da história das parcerias e das cadeias, dos planejamentos realizados, dos acordos firmados e dos resultados obtidos. 
Alguns pontos importantes para o processo de planejamento são:

- É importante reunir no planejamento pessoas que tenham experiência nas cadeias regionais e os atores centrais das mesmas, principalmente os extrativistas e empresas que tenham alinhamento mínimo com os princípios do grupo inicial;

- O envolvimento de todos os atores regionais que se envolvem na cadeia pode trazer riscos para o processo de planejamento, pois: i) o envolvimento de atores que não têm histórico de diálogo e que não compartilham dos princípios éticos objetivados pela cadeia pode trazer conflitos logo no início da cooperação; ii) o processo de planejamento pode evidenciar discordâncias de pontos de vista e entendimentos, disputas de liderança, necessidades de alinhamento etc, principalmente em um primeiro momento, podendo gerar desconfortos e afastamentos de atores importantes para processos de melhoria futuros;

- Pode-se buscar, no processo de planejamento, os princípios e objetivos gerais da cooperação;

- É importante levantar ou estruturar materiais que subsidiem o processo de planejamento com informações e dados, para facilitar análises e a tomada de decisão, especialmente informações das principais cadeias, volumes de produção históricos, informações socioeconômicas, informações logísticas e informações de custos de extração e transporte;

- É possível utilizar algumas ferramentas no processo de planejamento, sendo o mapa da cadeia de valor uma ferramenta importante para o alinhamento, para a estruturação de informações e para análise. Outras ferramentas complementares são: plano de ação, brain storming, análise FFOA (Forças, Fraquezas, Oportunidades e Ameaças), Protocolo Biocultural, estudos de custo etc;

- As realizações de reuniões periódicas de planejamento de curto prazo e monitoramento auxiliam o bom andamento da rede; 
- A sistematização das informações pode ser dividida com os membros da rede, de forma a não ficar concentrada em uma única instituição;

- A existência de um planejamento conjunto pode facilitar processos de captação de projetos e recursos para a melhoria das cadeias, tanto individualmente quanto coletivamente.

\subsection{Operação e Melhoria}

A operação remete ao dia-a-dia das cadeias, às atividades realizadas pelos diferentes atores e ao processo de cooperação em si. Os processos de melhoria ocorrem concomitantemente à operação, buscando aprimorar as cadeias e os processos a elas ligados. É durante a fase de operação e melhoria que o plano de ação da Rede definido pela orientação estratégica será implantado.

A operação direta de uma cadeia de valor de PFNM pode ser dividida em diferentes processos, sendo alguns: aquisição de insumos para o extrativismo; atividade extrativista em si; armazenamento/processamento dos produtos; marketing/comercialização (entre elos e para o consumidor); processamento industrial; e, serviços, dentre os quais podem ser inclusos os serviços socioculturais ambientais inerentes ao extrativismo em áreas protegidas, que gera um valor agregado ao produto.

A transformação de cadeias tradicionais em cadeias éticas demanda 0 entendimento dos processos e a formação e preparação dos atores da cadeia para assumi-los, modificá-los, controlá-los e monitorá-los. Ações mal estruturadas e sem entendimento/compromisso com o processo de mudança podem trazer prejuízos para a cadeia como um todo, especialmente para os elos mais fragilizados.

Uma estratégia central para as diferentes melhorias é o entendimento da cadeia e de mercados. No geral as ações de melhoria na cadeia possuem enfoque 
no aprimoramento de processos de extração e beneficiamento, deixando para segundo plano a relação com o mercado. Porém, a definição e operação dessas melhorias dificilmente funcionarão sem uma relação clara com o mercado, baseada em acordos de relacionamento e definições de qualidade que envolvam as necessidades dos diferentes atores.

Algumas ferramentas são úteis no relacionamento com o mercado, especialmente:

- Mapeamento e estudo da cadeia de valor e seus principais atores - o entendimento da cadeia local e da cadeia como um todo permite munir com informações o processo de negociação, especialmente ao buscar influenciar o comportamento de toda a cadeia;

- Protocolo Biocultural;

- Portifólio de produtos;

- Estudo de custos;

- Termos de cooperação simplificados;

- Canais formais de comercialização - o entendimento dos processos de comercialização é importante para negociações com os diferentes mercados. Algumas alternativas são possíveis de estruturação:

a. Comercialização conjunta com emissão de nota(s) de produtor rural ou micro empreendedor(es), com a organização dos extrativistas em grupos e emissão de nota no nome de um ou mais representantes;

b. Comercialização conjunta com emissão de nota via Associação ou Cooperativa;

c. Comercialização conjunta com negociação com intermediários locais;

Em posse dessas ferramentas os atores de apoio podem buscar as estratégias mais adequadas para intervir no mercado e na cadeia de valor. É recomendado que as ações de melhoria nos processos extrativistas estejam previamente associadas a ações da cadeia voltadas a comercialização, de forma que a melhoria na extração ou processamento reflita em valores justos e acordos de qualidade com o mercado. 
Dessa maneira, os atores de apoio podem agir em diferentes processos com estratégias distintas. Algumas estratégias gerais podem ser observadas:

- Influência na cadeia local e monitoramento;

- Influência na cadeia como um todo e monitoramento;

- Operacionalização de processos fragilizados da cadeia local e monitoramento.

A estratégia de influenciar a cadeia local e desempenhar ações de monitoramento visa a mobilização dos atores da cadeia para a estruturação e monitoramento de novos acordos voltados à construção de relações éticas e valores justos. Nessa linha, os atores de apoio podem auxiliar os operadores da cadeia na busca por melhorias em valores e em processos produtivos; na ampliação do acesso a financiamento e linhas de crédito etc.

A estratégia de influenciar a cadeia como um todo e desempenhar ações de monitoramento visa a mudança das relações de uma cadeia inteira, buscando influenciar os elos centrais, especialmente os reguladores e os mais próximos do mercado consumidor. Nessa estratégia, os atores de apoio buscam negociar com os principais elos e/ou atores de regulação mecanismos de controle que causem modificações na cadeia como um todo, influenciando novas práticas de relação entre os elos e garantias de padrões acordados. Dentre as ações que podem influenciar a cadeia como um todo pode-se citar a estruturação de: políticas públicas voltadas aos PFNM, moratórias de mercado e processos de certificação.

A estratégia de operacionalização de processos fragilizados tem como premissa ações na cadeia local articuladas com o mercado, porém com a necessidade de execução de atividades de fomento, processamento, armazenamento e comercialização com o suporte de atores não operacionais. A necessidade de operacionalização de processos fragilizados pode ocorrer por diferentes motivos, sendo alguns: dificuldade de negociação com elos locais da cadeia; necessidade de substituição de elos; estruturação de novas cadeias que não 
possuem agentes claros de mercado; necessidade de novos processos nas comunidades, que demandam tempo de aprendizado etc. Algumas cadeias podem demandar novos processos não dominados por operadores da cadeia ou atores de fomento, sendo necessários processos de negociação, operação e formação para que esse novo processo seja absorvido pelos operadores.

A operacionalização de processos por agentes não diretamente relacionados à cadeia traz em si um risco: a dependência da cadeia desse agente externo, o qual, normalmente, não depende da cadeia em si para sua manutenção. Por isso, ações que substituam atores ou que criem necessidades de formação e acompanhamento constantes devem ser bem planejadas e serem realizadas com grande entendimento/comprometimento com o processo de mudança desejado, pois 0 abandono do processo pode causar impactos negativos, especialmente nos elos mais frágeis.

A experiência na Terra do Meio mostrou a importância da existência de um tripé de cooperação como base de sustentação das cadeias de PFNM, formado por (Figura 17): i) Grupos extrativistas; ii) Grupo de organizações de apoio; e iii) organizações de mercado.

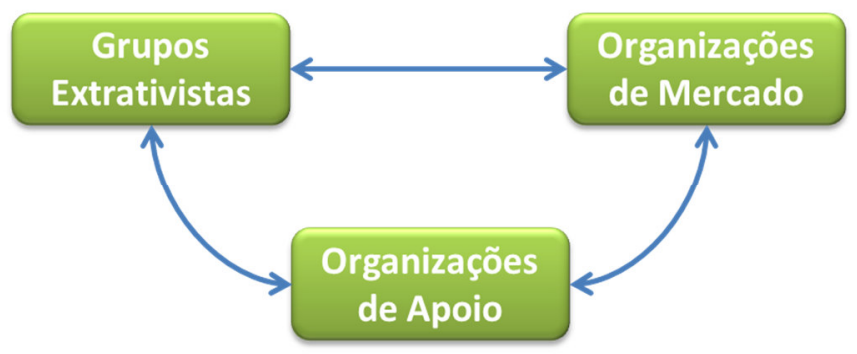

Figura 17: Subredes de melhoria e monitoramento das cadeias.

Os Grupos Extrativistas se caracterizam pelos grupos tradicionalmente constituídos em um território. Esses grupos podem se constituir por reciprocidade, proximidade, afinidade e relações de confiança. A organização dos extrativistas em grupos favorece o fortalecimento gradual da organização social, especialmente com 
iniciativas que demandam articulação entre os extrativistas e desses com os atores externos a suas áreas. Como exemplo, pode-se citar a operação de mecanismos de comercialização conjunta, a operacionalização de capitais de giro, as negociações com empresas, a construção de Protocolos Bioculturais, a organização para o escoamento da produção, organização para o acesso ao Programa de Aquisição de Alimentos (PAA) e ao Programa Nacional de Alimentação Escolar (PNAE) etc.

A ação das organizações de apoio pode mudar conforme a estratégia adotada e seu papel na cadeia, sendo a participação dessas organizações importante para: garantir o balanço de forças na relação comercial; garantir a troca de informações; aumentar a confiança na relação; operacionalizar processos fragilizados ou em construção; apoiar tecnicamente melhorias e processos formativos; preparar operadores da cadeia para assumir processos; apoiar grupos no acesso a direitos básicos e acesso a políticas públicas destinadas às cadeias da sociobiodiversidade; produzir e difundir informação para os demais atores regionais participantes ou não da rede; monitorar acordos e resultados da cooperação etc.

Assim, além de uma ação simples de melhoria na cadeia, as organizações de apoio exercem papel fundamental na conexão com o mercado (papel de Broker), gestão de parcerias, gestão de projetos e processos, formação técnica, gestão da informação, acompanhamento e monitoramento das cadeias.

A relação com as organizações de mercado aumentam a segurança da cadeia através de contratos, financiamentos e garantias de comercialização dos produtos. Essa relação mais próxima pode auxiliar na busca de melhorias de processos e qualidade. A cooperação entre empresas envolvidas com os mesmos atores da rede pode gerar economias transacionais com relação a investimentos, transportes, armazenamento e operação coordenada das cadeias. 


\subsection{Monitoramento / Avaliação}

Os diferentes processos de planejamento, operação e melhoria podem ser monitorados pelos atores locais. Esse monitoramento pode ocorrer de diferentes formas e pode evoluir com o amadurecimento da rede. É normal que o processo de monitoramento se inicie com processos mais informais e simples de acompanhamento da cadeia nas atividades de campo e reuniões, podendo evoluir para a definição de indicadores de desempenho quantitativos para as cadeias, processos de melhoria e processos de cooperação.

Alguns indicadores iniciais que podem ser observados são: melhoria de valor do produto, manutenção de atividades de subsistência e/ou competição/complementação com outras atividades, organização coletiva, viabilidade de operação dos processos determinados, funcionamento das ações propostas, mercados atingidos etc.

De maneira geral o processo de monitoramento pode evoluir para um sistema de medição de desempenho, que permita a quantificação de diferentes resultados para avaliação dos diferentes atores das cadeias. Esse sistema pode contemplar indicadores socioeconômicos, ambientais, da cadeia, de organização social e da cooperação em rede, incluindo o planejamento e sua execução, a captação de recursos, a organização dos grupos extrativistas etc.

A partir do monitoramento/avaliação dos processos e da cooperação o ciclo recomeça buscando a Evolução da Cooperação, com a reestruturação da rede, a continuidade do processo de mobilização e animação dos atores, o (re) planejamento e a operação dos processos; ou a rede opta pela sua Dissolução. 


\section{Conclusão}

A organização de cadeis de valor de PFNM mais éticas e dignas, que contemplem o modo de vida das populações tradicionais e gerem maior valor para a floresta manejada por elas é um desafio enfrentado pelos extrativistas, pelos operadores das cadeis, instituições não governamentais, governos e empresas.

Os PFNM são vistos como uma importante fonte de renda para a economia das comunidades tradicionais, porém, não suficiente para a redução da pobreza em áreas de floresta (MARSHALL; NEWTON; SCHRECKENBERG, 2003; MORSELLO, 2006). Os modos de vida estruturados pelas populações tradicionais em seus territórios, com as diferentes estratégias criadas e o conhecimento profundo dos recursos naturais, proporciona independência com relação a fontes de renda e cadeias específicas, como estudado por Almeida (2004) com relação aos seringueiros. Isso garante liberdade às populações na escolha de suas atividades produtivas e comerciais.

Essa liberdade de escolha das famílias está vinculada ao uso múltiplo dos recursos da floresta, a uma vasta rede de relações familiares e dessas com a sociedade envolvente. Parte dessa conexão com a sociedade envolvente ocorre através das cadeias de valor de PFNM, que segundo Te Velde et al. (2006) e Jensen (2009), são cadeias complexas e repletas de relações informais que nem sempre geram resultados positivos para as populações e territórios.

Algumas iniciativas vêm buscando caminhos diversos para a melhoria dessas cadeias e relações, sendo levantado pela literatura consultada: i) relação direta comunidade-empresa, como estudado por Morsello (2006), Le Tourneau e Greissing (2010); ii) relação empresa-comunidade mediada por uma instituição intermediária governamental ou não governamental, como estudado por Ribeiro F. (2009), Michi (2007); iii) a manutenção, melhoria e monitoramento das relações já instituídas nas cadeias de valor, como apontado por Te Velde et al. (2006); iv) relação em parceria para lidar com a governança florestal de forma mais abrangente, lidando com 
diferentes territórios, objetivos sociais e econômicos, incluindo os PFNM, com a criação de um contexto político, legal e institucional apropriado como apontado por Ros-Tonen et al. (2008).

A literatura que estuda esses diferentes caminhos aponta alguns riscos em suas análises, destacando-se os riscos de mudanças em estruturas centrais no modo de vida das populações tradicionais, tais como: i) relações comunitárias e de reciprocidade; ii) nas relações da comunidade com a floresta e agricultura de subsistência; iii) nas dinâmicas estabelecidas com diferentes elos das cadeias de valor de PFNM existentes. Essas relações e dinâmicas trazem para as populações da floresta a liberdade de escolha das atividades de maior interesse pela grande diversidade de fontes de recurso disponíveis em seu território e nas relações instituídas.

Não foram encontrados na literatura casos que descrevessem e trouxessem maiores detalhes da organização em rede ou formas de estruturação de parcerias mais amplas e de longo prazo para a promoção de melhorias nas cadeias de valor de PFNM. Os estudos levantados forneceram poucos direcionamentos quanto aos papéis dos diferentes atores dentro das cadeias de valor, de como a intervenção, intermediação e monitoramento ocorrem ou poderiam ocorrer no longo prazo e como as redes poderiam ser estruturadas.

Assim, através do estudo de caso realizado e da análise do caso frente à literatura, a tese traz como resultados e contribuições os seguintes pontos: i) a descrição e análise da rede de cooperação estruturada para a melhoria das cadeias de valor de PFNM da região da Terra do Meio; ii) as influências e contribuições da rede de cooperação para as cadeias da região; e, iii) a sistematização de diretrizes para a estruturação de redes de cooperação voltadas para as cadeias de valor de PFNM.

Vale destacar que a participação ativa do pesquisador ao longo do processo de estruturação da rede, desde 2006, foi fundamental para entender os detalhes dos 
processos de cooperação da Terra do Meio. Uma pesquisa realizada com poucas visitas a campo, através de entrevista proporcionaria à pesquisa um retrato simples da estrutura organizada, gerando, possivelmente, resultados diversos ao longo do tempo e das análises.

\section{O Caso da Rede Terra do Meio}

A rede de cooperação estruturada na Terra do Meio é complexa, envolvendo uma grande quantidade e diversidade de atores e temas com interesse ou responsabilidades sobre o território. Ao analisar a RTM percebe-se que a mesma é uma rede horizontal, informal, de longo prazo, direcionada para o desenvolvimento da região da Terra do Meio, que proporciona um ambiente para a cooperação interinstitucional e se divide em Grupos de Trabalho. Esses grupos são considerados na pesquisa como subredes orientadas por objetivos específicos, horizontais e autônomas quanto ao seu funcionamento e ação no território e que favorecem igualmente processos de cooperação. As diferentes instituições e subredes da RTM possuem objetivos que envolvem direta ou indiretamente as Populações Tradicionais residentes em áreas protegidas da Terra do Meio e se relacionam com essas populações de forma distinta.

Analisando a organização extrativista da Terra do Meio sob uma perspectiva de redes, cada família pode ser analisada como um nó independente e autônomo da rede, que possui relações próximas de reciprocidade, parentesco e compadrio e se relaciona com a sociedade através de um conjunto de relações pessoais, de troca e comércio. Com a criação das Reservas Extrativistas essa população passou a trabalhar com um número maior de atores, aumentando suas relações com instituições públicas e novas instituições que buscam apoiar a implantação efetiva de suas áreas contemplando aspectos sociais e ambientais.

Essa nova realidade gerou mudanças também na relação com as cadeias de valor, especialmente com a ação das instituições na melhoria dessas cadeias. As ações institucionais evoluíram de ações focadas na melhoria de processos 
produtivos nas comunidades para ações de melhoria na cadeia como um todo. Assim, comunitários e instituições passaram a ter que trabalhar com dinâmicas mais amplas de mercado e políticas públicas relacionadas a cada cadeia de valor. Esse processo demandou das redes, de instituições e de extrativistas, a melhoria dos da cooperação entre as instituições, entre os extrativistas e destes com atores das cadeias de valor.

Percebe-se que a evolução e ciclo de vida da RTM, do GT de Atividades Produtivas e suas subredes é similar ao observado na teoria de redes de cooperação estudadas por Söllvel (2009) e Camarinha-Matos e Afsarmanesh (2008). A cooperação em torno da RTM e no GT de Atividades Produtivas parte de processos de cooperação e ações conjuntas históricas de poucos atores envolvidos com a criação das Unidades de Conservação. A evolução da rede e subredes ocorreu de acordo com a operação e melhoria de processos de governança e ações conjuntas da mesma. Nessas ações houve a construção e desestruturação de laços de confiança, a resolução de conflitos e o aproveitamento de oportunidades de acordo com o ganho de competência da rede e suas instituições. O processo de cooperação e o cenário político local podem levar a modificação ou dissolução da RTM e do GT de Atividades Produtivas como espaço de promoção da cooperação, porém isso não implicaria necessariamente no fim da cooperação em si.

É importante observar que os processos desempenhados para a cooperação em rede na Terra do Meio possibilitou maior alinhamento e ganho de confiança entre os diferentes atores envolvidos direta e indiretamente na rede. Os processos e ações conjuntas realizadas entre as instituições gerou um aumento considerável de recursos direcionados para as UCs da Terra do Meio, os quais dificilmente seriam acessados pelas organizações individualmente, especialmente as associações comunitárias. Esses recursos são destinados a ações conjuntas nas cadeias de valor e nos demais escopos da rede, principalmente para proteção e regularização do território e políticas públicas saúde e educação.

Por fim, percebe-se que as redes e grupos extrativistas passaram a se 
conectar a novos atores e a redes focadas no desenvolvimento do território como um todo. Tornou-se importante para as diferentes redes conectadas e seus atores 0 compartilhamento do entendimento da realidade territorial e os caminhos necessários para a melhoria do mesmo no futuro, tanto para ações institucionais quanto para o desenvolvimento e implementação de políticas públicas.

Dessa mesma forma, o processo de organização e planejamento direcionado para as cadeias de valor de PFNM demandou e vem demandando melhorias na cooperação e coordenação das redes e subredes envolvidas. Processos de cooperação bem instituídos e compartilhados com os diferentes nós da rede podem gerar resultados mais duradouros no longo prazo nas cadeias de valor do que a orientação das ações da rede sem o compartilhamento de idéias, planos, riscos, projetos etc. Alguns desses resultados podem ser mais bem compreendidos ao se analisar a influência dessas redes nas cadeias de valor de PFNM.

\section{Influência das Redes de Cooperação nas Cadeias de Valor}

A análise do estudo de caso mostra que a organização em rede influenciou as cadeias de valor da Terra do Meio de diferentes maneiras. Essas influências podem ser categorizadas em: i) influências nos processos iniciais das cadeias de valor; ii) influência na cadeia local; iii) influência na cadeia como um todo; e iv) operacionalização de processos fragilizados da cadeia local articulado com 0 mercado.

As ações ao longo do processo de cooperação na melhoria das cadeias de valor de PFNM da Terra do Meio direcionaram as ações nos últimos anos para ações de melhoria na cadeia de valor de forma articulada com o mercado com a operacionalização de processos fragilizados e ainda não dominados pelas comunidades. Essa concentração de ações com bastante apoio operacional não descartou a possibilidade de ações com estratégias diferentes, que possibilitem a integração de operadores locais nas novas cadeias e relações estruturadas.

A organização de subredes voltadas para a operação e melhoria das cadeias 
de valor se estruturou no tripé "redes/grupos extrativistas" - "instituições de apoio" “organizações de mercado". Esse tripé trouxe para a relação na cadeia de valor o papel de um ou mais broker de facilitação de processos de cooperação. Esse papel, como apontado por Morsello (2006) e Ros-Tonen et al. (2008) foi fundamental para a estruturação de novas relações nas cadeias de valor de PFNM e para 0 monitoramento dos resultados dessas relações (TE VELDE et al., 2006).

Além da simples intermediação de um broker ou agente facilitador as parcerias estabelecidas na Terra do Meio passam pelo constante monitoramento das diferentes instituições participantes da Rede Terra do Meio. Pode-se sistematizar esse processo de monitoramento em diferentes âmbitos e etapas dentro da organização regional: i) pelos extrativistas no dia a dia da atividade e nos espaços de avaliação e planejamento instituídos (reuniões das cantinas, reuniões das associações e reuniões de avaliação e planejamento das cadeis de valor); ii) pelas atividades das instituições nas comunidades; iii) nos encontros do GT de Atividades Produtivas e Rede Terra do Meio. Observa-se que o processo de avaliação e monitoramento decorrente do processo de cooperação na Terra do Meio apoia a diminuir riscos de relações de intermediação mal estruturados como estudado por Ribeiro F. (2009).

A existência de diferentes âmbitos de cooperação para o território favorece também o acesso das populações a direitos e políticas públicas. $O$ acesso a esses direitos, principalmente ligados à documentação, saúde e educação, são requisitos inerentes à qualidade de vida, trabalho e relações sociais e à capacidade de mudar a realidade das comunidades envolvidas com essas cadeias (POKORNY et al., 2012). Essa ação multi-temática, promovida pela cooperação na RTM, permite que não seja direcionado para a relação com os operadores de mercado as responsabilidades do Estado, como estudado por Le Tourneau e Greissing (2010), e viabiliza o ganho de competência em gestão dos extrativistas e associações no longo prazo.

A cooperação entre os atores e a coordenação das ações na cadeia 
proporcionou um conjunto de resultados, verificados nas ações na Terra do Meio, tais como:

- Aumento da distribuição das informações sobre as cadeias nos grupos extrativistas, instituições e organizações de mercado;

- Aumento de dialogo intersetorial para cooperação;

- Aumento da compreensão das diferentes realidades, principalmente pelos operadores das cadeias: as comunidades e empresas;

- Estruturação de espaços de resolução de conflitos, já que a interação entre atores pode potencializar os mesmos pelo aumento de dialogo e divisão de liderança;

- Melhora da coordenação das ações nos territórios;

- Aumento de relações mais horizontais no território e nas cadeias de valor;

- Maior distribuição de poder nas relações e tomada de decisão;

- Aumento gradual da organização social dos extrativistas para um maior controle dos processos de produção e comercialização;

- Possibilidade de ganho de escala para comercialização na organização extrativista;

- Aumento da comunicação, controle e monitoramento pelas partes;

- Maior transparência nas relações;

- Compartilhamento de desafios e soluções;

- Maior entendimento e monitoramento de riscos inerentes ao negócio para as comunidades e para as organizações de mercado;

- Maior chance de cumprimento dos acordos estabelecidos;

- Ganho gradual de capital social, organização e governança;

- Ações direcionadas na resolução de outros passivos socioambientais (saúde, educação, transporte, documentação etc.), que poderiam ser totalmente direcionados para a relação de mercado;

- Incorporação de novos conceitos nas relações comerciais regionais (relação ética, rastreabilidade, certificação de origem); 
Uma fragilidade e risco encontrada na estratégia de operar processos das cadeias de valor é a substituição de operadores da cadeia por atores que não dependem diretamente do sucesso das cadeias, como apontado por Te Velde et al. (2006). Essa operação demanda dos atores maiores recuros e envolvimento de longo prazo para a criação de sistemas mais flexíveis que contemplem a organização extrativista existente e seus agentes em formação. A operação dos processos com a estrutura existente no território em 2014 seria muito complexa e onerosa para as comunidades, sendo necessário buscar caminhos que direcionem os processos de assistência técnica para o Estado, que tragam valorização aos produtos, que contemplem novas formas de operação ou insiram os operadores locais em cadeias mais éticas.

Observa-se, de forma complementar ao apontado por Le Tourneau e Greissing (2010), que as ações de melhoria levam a processos de mudança inevitáveis para as cadeias de valor e comunidades. Na Terra do Meio essas mudanças tiveram início com a entrada de agentes externos interessados nas terras e recursos naturais das populações tradicionais e posteriormente na entrada de instituições governamentais e não governamentais com a criação das Unidades de Conservação e Terras Indígenas. Todo esse processo territorial, incluindo as cadeias de valor, demanda novos conhecimentos e formas de organização complementares e pautadas na organização e conhecimento existentes.

Essa nova organização das Populações Tradicionais da Terra do Meio deve lidar com o conhecimento tradicional, com a gestão do território, com processos de beneficiamento e comercialização, com articulações políticas e outros desafios de governança do território. Há nas Resex da Terra do Meio um processo em construção, que vai demandar das comunidades e instituições um comprometimento de longo prazo e a melhoria constante dos processos de cooperação.

Somente o comprometimento de longo prazo com o processo, buscando a participação efetiva da comunidade, pode garantir o monitoramento, avaliação e ajustes das estratégias adotadas, de forma a desenvolver soluções que respeitem 0 
modo de vida das populações e a melhora na gestão do território e das cadeias de valor.

Diretrizes para estruturação de redes de cooperação voltadas para as cadeias de PFNM

As diretrizes propostas pela tese tomaram como base 0 conhecimento organizado no estudo de caso e a literatura de redes de cooperação. A proposta apresentada é flexível e não busca responder a todos os aspectos de gestão de redes e sim apresentar os aspectos centrais observados nos processos de cooperação da Terra do Meio.

As diretrizes organizadas em processos apresenta a necessidade constante de mobilização de atores e (re) estruturação da rede devido a necessidade da rede ter que lidar com dinâmicas locais adversas e com a rotatividade de atores. Esse processo de mobilização demanda atores específicos para fomentar a cooperação que realizem o papel de broker ou agente facilitador da cooperação. A forma da estrutura organizada para a cooperação é diversa e mutável ao longo do tempo e da maturidade, podendo contemplar desde simples espaços que promovam processos de planejamento, cooperação e monitoramento a estruturas mais formais como as Agências de Desenvolvimento Regional (ADR) já estudadas por Gerolamo (2007) e Provan, Fish e Sydow (2007).

Indica-se que o início do processo de cooperação contemple os principais atores regionais que já possuem relação, e que se parta de ações conjuntas entre esses atores para o ganho de confiança e maturidade para cooperação. Essas experiências conjuntas conduzirão à necessidade de uma Orientação Estratégica para as ações e processos de cooperação. A inserção dos diferentes atores envolvidos na cadeia com o processo de planejamento e cooperação pode ser gradual e conforme os laços são instituídos para evitar que conflitos e indisposições iniciais inviabilizem a cooperação.

É na operação das cadeias e na realização de melhorias que o processo de 
cooperação tem sua maior interação com os grupos extrativistas e atores de operação. As formas de intervenção e de melhoria são diversas podendo contemplar melhorias nas cadeias locais instituídas, melhorias na cadeia como um todo e mesmo a operação de alguns processos associado a melhorias de mercado. De maneira geral é importante a realização de melhoria nas cadeias de forma coordenada à (re) estruturação de mercados. Pois o engajamento dos diferentes atores de operação das cadeias demanda melhorias na cadeia inteira. Assim, propõe-se que os processos de operação e melhoria sigam o tripé observado na Terra do Meio que contempla: grupos extrativistas - organizações de apoio Organizações de Mercado.

As diferentes estratégias e ações realizadas podem ser avaliadas e monitoradas em diferentes âmbitos e processos. Inicialmente os monitoramentos envolvem a organização extrativista existente, a interação entre organizações e extrativistas e o monitoramento nos espaços políticos instituídos. Com o amadurecimento da rede é possível a estruturação de indicadores de desempenho que contemplem aspectos centrais daa cooperação, das estratégias, do território e das populações.

Por fim, a avaliação do processo de cooperação pode levar à necessidade de mudanças e evolução na estrutura, orientação estratégica, formas de operação e formas de monitoramento ou levar o grupo à dissolução da rede e dos processos de cooperação. 


\section{Limitações e sugestões para trabalhos futuros}

Como limitação, a pesquisa apresenta resultados de um único caso de cooperação. Isso pode restringir a generalização dos resultados para outras redes e territórios. Outra limitação da pesquisa é a pouca profundidade quanto à análise social e da organização das comunidades, de suas redes e do impacto das redes nessas dinâmicas, dado o escopo principal deste trabalho na estrutura de governança das redes voltadas para as cadeias de PFNM e de sua influência nas cadeias de valor.

Com base nessas limitações e nas possibilidades de continuidade desse trabalho sugerem-se os seguintes temas para serem trabalhados em pesquisas futuras:

- As mudanças ocorridas na organização social das comunidades com o surgimento de novos atores (madeireiros, grileiros, governo, ONGs etc) e relações com a sociedade e cadeias de valor;

- As relações de poder nas redes e sua evolução ao longo do tempo;

- O estudo dos níveis de maturidade da rede e possíveis formas de organização dentro de cada nível;

- As possíveis formas de organização formais (associações, cooperativas, empresas ou organizações combinadas como consórcios) para vializar a cooperação em rede e a melhoria dos processos de comercialização;

- Desenvolvimento de processos de indicadores de monitoramento que contemplem o processo de cooperação, os resultados nas cadeias de valor e os impactos nas comunidades e floresta;

- Estudos sobre as possíveis formas de valoração dos serviços socioculturais e ambientais prestados pelas populações e seus territórios através dos produtos tradicionalmente trabalhados e PFNM;

- Estudo de outras redes voltadas às cadeias de valor de PFNM. 


\section{REFERÊNCIAS}

ABRAMOVAY, R.O capital social dos territórios: repensando 0 desenvolvimento rural. Economia Aplicada, v. 4, n. 2, p. 379-397, 2000.

ALLEGRETTI, M. H. A Construção Social de Políticas Ambientais - Chico Mendes e o Movimento dos Seringueiros. 2002. Tese (Doutorado) - Centro de Desenvolvimento Sustentável, UNB, Brasília, 2002.

ALMEIDA, M.W.B. Direitos à floresta e ambientalismo: seringueiros e suas lutas. Revista Brasileira de Ciências Sociais, v.19, n. 55, p. 33-53, 2004.

AMATO NETO, J. Redes de cooperação produtiva e clusters regionais. São Paulo: Atlas. 2000.

AMATO NETO, J.; FUCCI AMATO, R. C.Capital social: contribuições e perspectivas teórico-metodológicas para a análise de redes de cooperação produtiva e aglomerações de empresas. Revista Gestão Industrial, v. 5, n. 1, p. 18-42, 2009.

ANDRADE, F.G.; MATTOS, A. A.; ARAÚJO, J. C. A constituição do campesinato na Amazônia e suas estratégias de reprodução: o caso da comunidade de São Bento no estado do Acre. XLVI Congresso da Sober, p. 1-5. 2008. Disponível em: http://www.sober.org.br/palestra/9/507.pdf\%20. Acesso em: 29 jul. 2011.

BECKER, B.; LENÁ, P. Pequenos Empreendimentos Alternativos na Amazônia. In: LASTRES, H.M.M.; CASSIOLATO, J.E.; MACIEL, M.L. (Org.). Pequena Empresa - Cooperação e Desenvolvimento Local. Rio de Janeiro: Relume Dumará. Cap.23, p.403-421, 2003.

BELCHER, B.; RUÍZ-PÉREZ, M.; ACHDIAWAN, R. Global Patterns and Trends in the Use and Management of Commercial NTFPs: Implications for Livelihoods and Conservation. World Development, v. 33, n. 9, p. 1435-1452, 2005.

BELL, J.; OUDEN, B.; ZIGGERS G. W. Dynamics of Cooperation: At the Brink of Irrelevance. Journal of Management Studies, v. 43, n. 7, p. 1607-1619, 2006.

BRASIL. Decreto № 6.040, de 7 de fevereiro de 2007. Institui a Política Nacional de Desenvolvimento Sustentável dos Povos e Comunidades Tradicionais. 2007. 
Ministério do Meio Ambiente; Ministério de Desenvolvimento Agrário; Ministério do Desenvolvimento Social. Cadeias dos produtos da sociobiodiversidade: agregação de valor e consolidação de mercados sustentáveis. Relatório técnico. Brasília - DF. 2008a Disponível em: http://comunidades.mda.gov.br/dotlrn/clubs/planonacionaldepromoodosprodutosdaso ciobiodiversidade/one-community?page num=0. Acesso em: 08 mai. 2010.

Ministério do Meio Ambiente; Ministério de Desenvolvimento Agrário; Ministério do Desenvolvimento Social. Cadeias de produtos da sociobiodiversidade: desafios e oportunidades - diálogo com o setor empresarial. Relatório técnico. São Paulo - SP. 2008b. Disponível em: http://comunidades.mda.gov.br/dotlrn/clubs/planonacionaldepromoodosprodutosdaso ciobiodiversidade/one-community?page num $=0$ Acesso em: 08 mai. 2010.

- Ministério do Meio Ambiente; Ministério de Desenvolvimento Agrário; Ministério do Desenvolvimento Social. Plano Nacional de Promoção das Cadeias de Produtos da Sociobiodiversidade. Brasília - DF. 2009a. Disponível em:

http://comunidades.mda.gov.br/dotlrn/clubs/planonacionaldepromoodosprodutosdaso ciobiodiversidade/one-community?page num $=0$. Acesso em: 08 mai. 2010.

Ministério do Meio Ambiente; Ministério de Desenvolvimento Agrário; Ministério do Desenvolvimento Social. Plano Nacional de Promoção de Produtos das Cadeias da Sociobiodiversidade - Balanço 2009. Relatório técnico. Brasília - $2009 \mathrm{~b}$ DF. Disponível em:http://comunidades.mda.gov.br/dotlrn/clubs/planonacionaldepromoodosprodutos dasociobiodiversidade/one-community?page num=0. Acesso em: 08 mai. 2010.

Ministério do Meio Ambiente; Ministério de Desenvolvimento Agrário; Ministério do Desenvolvimento Social. Promoção Nacional da Cadeia de Valor do Coco Babaçu. Relatório Técnico. Brasilia, 2009c.

Ministério do Meio Ambiente; Ministério de Desenvolvimento Agrário; Ministério do Desenvolvimento Social. Plano Nacional de Promoção de Produtos das Cadeias da Sociobiodiversidade - Plano de Ação 2010. Relatório técnico. Brasília $\quad-\quad$ DF. 2010.2 Disponível em:http://comunidades.mda.gov.br/dotlrn/clubs/planonacionaldepromoodosprodutos dasociobiodiversidade/one-community?page num=0. Acesso em: 08 mai. 2010.

Ministério do Meio Ambiente; Ministério de Desenvolvimento Agrário; Ministério do Desenvolvimento Social. Plano Nacional de Promoção de Produtos das Cadeias da Sociobiodiversidade. Informe Sociobiodiversidade, n. 4. Brasília

DF. 2011.

Disponível em: 
http://comunidades.mda.gov.br/dotlrn/clubs/planonacionaldepromoodosprodutosdaso ciobiodiversidade/one-community?page num=0. Acesso em: 08 abr. 2012.

2013. Ministério do Meio Ambiente. Lista dos municípios prioritários. http://www.mma.gov.br/images/arquivo/80120/lista prioritarios doc14 10 2013.pdf). Acesso em: 28 jan. 2014.

BUTLER, R.; LAURANCE, W. F. New strategies for conserving tropical forests.Trends in ecology \& evolution, v. 23, n.9, p. 469-72, 2008.

CAMARINHA-MATOS, L. M.; ABREU, A. Performance indicators for collaborative networks based on collaboration benefits. Production Planning and Control, v. 18, n. 7, p. 592-609, 2007.

CAMARINHA-MATOS, L.M.; AFSARMANESH; H. A comprehensive modeling framework for collaborative networked organizations.Journal of Intelligent Manufacturing, v. 18, n. 5, p. 529-542, 2007.

On reference models for collaborative networked organizations.International Journal of Production Research, v. 46, n. 9, p. 24532469, 2008.

CAMPOS, M. T.; NEPSTAD, D.C. Smallholders, the amazon's new conservationists.Conservation Biology, 2006, v. 20, n. 5, 1553-1556.

CARPINETTI, L.C.R.; GALDÁMEZ, E.V.C.; GEROLAMO, M.C.A measurement system for managing performance of industrial clusters: a conceptual model and research cases. International Journal of Productivity and Performance Management, v. 57, p.405-419, 2008.

CASSIOLATO, J. E.; LASTRES, H. M. M. O foco em arranjos produtivos e inovativos locais de micro e pequenas empresas. In: LASTRES, H.M.M.; CASSIOLATO, J.E.; MACIEL, M.L. (Org.). Pequena empresa - cooperação e desenvolvimento local. Rio de Janeiro: Relume Dumará. Cap.1, p.21-34, 2003.

COMPANHIA NACIONAL DE ABASTECIMENTO. Conjuntura Mensal Relatório. $2013 . \quad$ Disponível em: http://www.Conab.gov.br/OlalaCMS/uploads/arquivos/13 1219091942 babacun ovembro13.pdf. Acesso em: 15 jan. 2014. 
COOPERAÇÃO TÉCNICA ALEMÃ. Arranjos Produtivos Locais na Região do Médio Xingu e Transamazônica. Relatório. Cooperação Técnica Alemã. Brasilia. 2009.

DE SARTRE, X. A.; TARAVELLA, R. National sovereignty vs. sustainable development lessons from the narrative on the internationalization of the Brazilian Amazon.Political Geography, v. 28, n. 7, p. 406-415, 2009.

ECOVIDA. Rede de agroecologia Ecovida. 2012. Disponível em: http://www.ecovida.org.br/. Acesso em: 2 mai. 2012.

EMPÓRIO DO CERRADO. Rede de Comercialização Solidária de Agricultores Familiares e Extrativistas do Cerrado. Disponível em: http://www.emporiodocerrado.org.br/pt-br/. Acesso em: 2 mai. 2012.

FEARNSIDE, P. M.Conservation Policy in Brazilian Amazonia: Understanding the Dilemas. World Development, v. 31, n. 5, p. 757-779,2003.

GEROLAMO, M. C. Modelo de referência em gestão de desempenho de clusters e redes regionais de cooperação de pequenas e médias empresas estudos de casos brasileiros e alemães. 2007. Tese (Doutorado) - Escola de Engenharia de São Carlos, Universidade de São Paulo, São Carlos, 2007.

GEROLAMO, M. C.; CARPINETTI, L.C.R.; SELIGER, G.; GALDÁMEZ, E.V.C. Performance management of regional clusters and SME cooperation networks. International Journal of Business Excellence, v. 1, n. 4, p. 457-483, 2008.

GUERRERO, N.; FURUIE, V.; TORRES, M. A Camisa Verde Compromisso Social e Produção Científica em Atividade de Extensão Universitária na Amazônia. XIX EŅCONTRO NACIONAL DE GEOGRAFIA AGRÁRIA, p. 1-23, 2009.

GUERRERO, N.; TORRES, M.; CAMARGO, M. L. Exclusão Participativa Conflitos em torno da gestão das unidades de conservação ambiental hoje. $V$ Simpósio Internacional de Geografia Agrária/VISimpósio Nacional de Geografia Agrária, Porto Alegre, 2011.

HOMMA, A.K.O. A (ir)racionalidade do extrativismo vegetal como paradigma de desenvolvimento agrícola para a Amazônia. In: COSTA, J.M.M. (Org.). Amazônia: desenvolvimento ou retrocesso, p. 63-207. Coleção Amazoniana 2. CEJUP, Belém, 1992.

INGRAM, V. J. Win-wins in forest product value chains? How governance 
impacts the sustainability of livelihoods based on non-timber forest products from Cameroon. Tese (Doutorado). Faculty of Social and Behavioural Sciences. University of Amsterdam (UvA). 2014. Disponível em: http://dare.uva.nl/document/515924. Acesso em: 2 jul. 2014.

INSTITUTO BRASILEIRO DE GEOGRAFIA E ESTATíSTICA. Produção da Extração Vegetal e Silvicultura - Comentários, v.27, 2012, Instituto Brasileiro de Geografia e Estatística. Disponível em: ftp://ftp.ibge.gov.br/Producao Agricola/Producao da Extracao Vegetal e da Silvic ultura [anual]/2012/comentarios.pdf. Acesso em: 29 jun. 2014.

INSTITUTO BRASILEIRO DE MEIO AMBIENTE E RECURSOS NATURAIS. Diagnóstico Socioeconômico da Reserva Extrativista Riozinho do Anfrísio. Altamira, 2007a.

Iriri, Altamira, 2007b.

Diagnóstico Socioeconômico da Reserva Extrativista Rio

INSTITUTO CHICO MENDES DE CONSERVAÇÃO DA BIODIVERSIDADE. Plano de Manejo da Resex Riozinho do Anfrísio. Brasília. 2010a.

Plano de Manejo da Resex Rio Iriri. Brasília. 2010b.

INSTITUTO DE MANEJO E CERTIFICAÇÃO FLORESTAL E AGRÍCULA. Avaliação econômica das principais cadeias de produtos da Sociobiodiversidade da Resex Riozinho do Anfrísio. Relatório Técnico. Imaflora. Altamira. 2010a.

Avaliação econômica das principais cadeias de produtos da Sociobiodiversidade da Resex Rio Iriri. Relatório técnico. Imaflora. Altamira. 2010b.

Avaliação econômica das principais cadeias de produtos da Sociobiodiversidade da Resex Rio Xingu. Relatório técnico. Imaflora. Altamira. 2010c.

INSTITUTO SOCIOAMBIENTAL. Seminário "Perspectivas para a Terra do Meio". Relatório. Altamira. 2006.

Altamira. 2007.

. II Seminário "Perspectivas para a Terra do Meio". Relatório. 
Programa Xingu. Disponível em: http://www.socioambiental.org/prg/xng.shtm. Acesso em: 10 mai. 2012. Instituto Socioambiental, 2013.

. De Olho em Belo Monte: 2013, no pico da contradição.

JENSEN, A. Valuation of non-timber forest products value chains. Forest Policy and Economics, v. 11, n. 1, p. 34-41, 2009.

LE TOURNEAU, F. M.; GREISSING, A. A quest for sustainability: Brazil nut gatherers of Sao Francisco do Iratapuru and the Natura Corporation. Geographical Journal, v. 176, p. 334-349, 2010.

MANESCHY, M. C.; KLOVDAHL, A. Redes de associações de grupos cp.amponeses na Amazônia Oriental (Brasil): fontes de capital social?.REDESRevista hispana para el análisis de redes sociales, v. 12, n. 4, p. 1-19, 2007. Co. 1920 .

MARSHALL, A. Principles of Economics. 8. ed. London: Macmillan and

MARSHALL, E.; NEWTON, A.C.; SCHRECKENBERG, K. Commercializing non-timber forest products: first steps in analyzing the factors influencing success. International forestry Review, v. 5, n. 2, p. 128-137, 2003.

analyzing the factors influencing success. UNEP World Conservation Monitoring Centre, Cambridge, UK, 2006.

MEDAETS, J.P.P. A construção da qualidade na produção agrícola familiar: sistemas de certificação de produtos orgânicos.2003. Tese (Doutorado) - Centro de Desenvolvimento Sustentável da Universidade de Brasília, UNB, Brasília, 2003.

MEDAETS, J. P. P.; MEDEIROS, J. X. A ação coletiva no controle da qualidade da produção orgânica familiar: Análise comparativa entre a certificação por auditoria externa e a certificação participativa em rede. In: Anais do XLII Congresso da Sociedade Brasileira de Economia e Sociologia Rural, Cuiabá, 2004, p. 366-366.

MEYER-STAMER, J. Estratégia de desenvolvimento local e regional: clusters, política de localização e competitividade sistêmica. ILDES, in F.E. Stiftung (Ed.) Policy Paper, n.28, September, 2001. 
MICHI, L. N. O papel do Estado nas percerias comerciais entre povos indígenas amazônicos e empresas na comercialização de produtos florestais não madeireiros. Dissertação (Mestrado). Programa de Pós Graduação em Ciência Ambiental (Procam) da USP. São Paulo: 2007.

MORSELLO, C. Company-community non-timber forest product deals in the Brazilian Amazon: A review of opportunities and problems. Forest Policy and Economics, n. 8, p. 458-494, 2006.

MORSELLO, C.; RUIZ-MALLÉN, I.; DIAZ, M.D.M.; REYES-GARCIA, V. The Effects of Processing Non-Timber Forest Products and Trade Partnerships on People's Well-Being and Forest Conservation in Amazonian Societies. PLoS ONE, v. 7, n.8, 2012. Disponível em: http://www.plosone.org/article/info\%3Adoi\%2F10.1371\%2Fjournal.pone.0043055. Acesso em: 20 jun. 2014.

MURDOCH, J. Networks - a new paradigm of rural development?Journal of Rural Studies, v. 16, n. 4, p. 407-419, 2000.

NKEM, J.; KALAME, F. B.; IDINOBA, M.; SOMORIN, O. A.; NDOYE, O.; AWONO, A.Shaping forest safety nets with markets: Adaptation to climate change under changing roles of tropical forests in Congo Basin. Environmental Science \& Policy, v. 13, n. 6, p. 498-508, 2010.

OLIVEIRA, R.M.; HESPANHOL, R.A.M. O agroextrativismo praticado pelos povos tradicionais do cerrado como alternativa de reprodução social econômica e cultural. Revista Geográfica da América Central, n. especial EGAL, p. 1-19, 2011.

OLIVER, A.; EBERS, M. Networking Network Studies: An Analysis of Conceptual Configurations in the Study of Inter-organizational Relationships. Organization Studies, v. 19, n. 4, p. 549-583,1998.

PARRILLI, M. D.; SACCHETTI, S. Linking learning with governance in networks and clusters: key issues for analysis and policy. Entrepreneurship \& Regional Development: An International Journal, v. 20, n. 4, p. 387-408, 2008.

PLISSON, J.; LJUBIC, P.; MOZETIC, I.; LAVRAC, N.An Ontology for Virtual Organization Breeding Environments. IEEE transactions on systems, man, and cybernetics - part c: applications and reviews, v. 37, n. 6, p. 1327-1341, 2007.

POKORNY, B.; JOHNSON, J.; MEDINA, G.; HOCH, L. Market-based conservation of the Amazonian forests: Revisiting win-winexpectations. Geoforum, v. 43, n. 3, p. 387-401, 2012. 
PORTER M. E. Clusters and the new economics of competition. Harvard Business Review, New York, November-December, v.76, n.6, p.77-90, 1998.

POSTIGO, A. A. A terra vista do alto: usos e percepções acerca do espaço entre os moradores do Rio Bagé, Acre. 2010. Tese (doutorado) - Antropologia Social, Unicamp, Campinas, 2010.

PROVAN, K.G.; FISH, A.; SYDOW, J. Interorganization networks at network level: a review of empirical literature on whole networks. Journal of Management, $v$. 33, p. 479-516, 2007.

REDE DE COMERCIALIZAÇÃO DO CERRADO. O saber fazer técnico e político dosmonitores (as)agroextrativistas do Cerrado num processo em Rede. (S/D) Disponível em: http://www.emporiodocerrado.org.br/ptbr/documentos/sistematizacao-rede-comercializacao.pdf. Acesso em: 3 mai. 2012.

REDE TERRA DO MEIO. Relatório da terceira reunião da Rede Terra do Meio. Relatório. Altamira. 2008.

Altamira. 2009.

. Relatório da quarta reunião da Rede Terra do Meio. Relatório.

Altamira. 2010.

. Relatório da quinta reunião da Rede Terra do Meio. Relatório.

Altamira. 2011a.

. Relatório da sexta reunião da Rede Terra do Meio. Relatório.

- Plano de Ação: Estratégias para as principais cadeias de produtos extrativistas da Terra do Meio. Relatório. Altamira. 2011b.

Relatório. Altamira. 2012.

Relatório da sétima reunião da Rede Terra do Meio. . Relatório da oitava reunião da Rede Terra do Meio. Relatório. Altamira. 2013.

RIBEIRO, D. O Povo Brasileiro - A Formação e o Sentido do Brasil. São Paulo: Schwarcz. 1995.

RIBEIRO, F. A. N. Etnodesenvolvimento e o mercado verde na Amazônia indígena: os Asuriní no Médio Xingu. 2009. 179 f. Dissertação (Mestrado) - 
Programa de Pós-Graduação em Ciência Ambiental, Universidade de São Paulo, São Paulo, 2009.

ROESCH, S.M.A. Projetos de estágio e de pesquisa em administração. 2. ed. São Paulo: Atlas, 1999.

ROS-TONEN, M. A. F.; ANDEL, T. V.; MORSELLO, C.; OTSUKI, K.; ROSENDO, S.; SCHOLZ, I. Forest-related partnerships in Brazilian Amazonia: There is more to sustainable forest management than reduced impact logging. Forest Ecology and Management, v. 256, p. 1482-1497, 2008.

SALISBURY, D.; SCHMINK, M. Cows versus rubber: Changing livelihoods among Amazonian extractivists. Geoforum, v. 38, n. 6, p. 1233 - 1249, 2007.

SCHMITZ, H. Collective efficiency: growth path for small-scale industry. The Journal of Development Studies, v. 31, n. 4, p. 529-566, 1995.

SANTOS, L.C.R. Certificação participativa em rede: um processo de certificação adequado à agricultura familiar agroecológica no sul do Brasil. Relatório. Projeto CNPQ n 52.0847/01-6. Centro de Estudos e Promoção da Agricultura de Grupo - CEPAGRO, junho, 2005. Disponível em: http://www.centroecologico.org.br/index.php. Acesso em: 4 maio 2012.

SCHUH, G.; WEGEHAUPT, P. Die Virtuelle Fabrik: lesson learned Zehn Jahre Danach, in: Stanoevska-Slabeva, K. (Ed.). The Digital Economy - Anspruch und Wirklichkeit, Festschrift für Beat F. Schmid, Berlin-Heidelberg-New York, p. 183198, 2004.

SILVA, A. K.;PORTO-GONÇALVES, C. W. Territórios em Rede: a criatividade político-cultural dos Povos do Cerrado. In: PORTO-GONÇALVES, C. W. (ORG.) Os Cerrados vistos por seus povos: O Agroextrativismo no cerrado. Centro de Desenvolvimento Agroecológico do Cerrado. Goiânia-GO, p. 68-95, 2008.

SCHWARTZMANN, S., ALENCAR, A., ZARIN, H, SOUZA, A.P.S. Social Movements and Large-Scale Tropical Forest Protection on the Amazon Frontier: Conservation From Chaos. The Journal of Environment \& Development, 2010, 19 (3), 274-299.

SCHWARTZMAN, S.; VILLAS BOAS, A.; ONO, K.Y.; FONSECA, M.G.; DOBLAS, J.; ZIMMERMAN, B.; JUNQUEIRA, P.; JEROZOLIMSKI, A.; SALAZAR, M.; JUNQUEIRA, R.P.; TORRES, M. The natural and social history of the indigenous lands and protected areas corridor of the Xingu River basin. Philosophical Transactions of the Royal Society. London, v. 368, n. 1619, jun. 2013. 
SILVA, A.K.; EGITO, M. Rede de Comercialização Solidária de Agricultores Familiares e Extrativistas do Cerrado: um novo protagonismo social. Agriculturas, junho de 2005, v. 2, n.2, p. 14-16, 2005.

SÖLVELL, O. Clusters - Balancing evolutionary and constructive forces. 2. ed., Stockholm: Ivory Towers, 2009.

SÖLVELL, O., LINDQVIST, G., KETELS, C. The Cluster Initiative Greenbook.1.ed., Stockholm: Ivory Towers AB, 2003.

SOUZA, A. P. S. O Desenvolvimento socioambiental na Transamazônica: a trajetória de um discurso a muitas vozes. 2006. Dissertação (Mestrado) - Núcleo de Estudos Integrados de Agricultura Familiar, UFPA, 2006.

STOIAN, D. Making the Best of Two Worlds: Rural and Peri-Urban Livelihood Options Sustained by Nontimber Forest Products from the Bolivian Amazon .Forest Policy and Economics, v. 33, n. 9, p. 1473-1490,2005.

STRAATMANN, J., GEROLAMO, M.C., CARPINETTI, L.C.R. Value Network of Amazon Non Timber forest Products: A Mapping Tool to Support a complex network Strategic Planning. In: 12th IFIP - International Federation for Information Processing - WG 5.5 Working conference on virtual Enterprises, São Paulo. Adaptation and Value Creating Collaborative Networks, p. 77-84, 2011.

TE VELDE, D. W.; RUSHTON, J.; SCHRECKENBERG, K.; MARSHALL, E.; EDOUARD, F.; NEWTON, A.; ARANCIBIA, E. Entrepreneurship in value chains of non-timber forest products. Forest Policy and Economics, v.9, n.7, p. 275-741, 2006.

TORRES, M. "A despensa viva: o banco de germoplasma dos roçados da floresta amazônica". Geografia em questão. v. 04, n. 02, p. 113-138, 2011.

VACCARO, I.; ZANOTTI, L. C.; SEPEZ, J. Commons and markets: opportunities for development of local sustainability. Environmental Politics, v. 18, n. 4, p. 522-538, 2009.

VASCONCELOS, V. O. ; SIQUEIRA, C. T.; SANTOS, R.; SALAZAR, M.; STRAATMANN, J.; NEVES, L.; CAMPOS, P. G. Inclusão Social e Educação Popular: uma Experiência em Reservas Extrativistas na Terra do Meio. Ambiente \& Educação (FURG), v. 15, p. 47-66, 2010,

VILLAS BOAS (ORG). De Olho na Bacia do Xingu. Série Cartô Brasil Socioambiental, v. 5. Instituto Socioambiental, 2012. 
VELÁSQUEZ, C., VILLAS BOAS, A., SCHWARTZMAN, S. Desafio para a gestão ambiental integrada em território de fronteira agrícola no oeste do Pará. Revista de Administração Pública, 2006, 40 (6), 1061 - 1075.

WALKER, R.; BROWDER, J.; ARIMA, E.; SIMMONS, C.; PEREIRA, R.; CALDAS, M.; SHIROTA, R.; ZEN, S. Ranching and the new global range: Amazônia in the 21st century. Geoforum, v. 40, p.732-745, 2009.

WOORTMANN, K. O modo de produção doméstico em duas perspectivas: Chayanov e Sahlins. Brasília: UNB/ Departamento de Antropologia/Instituto de Ciências Sociais. Série Antropologia. N. 293. 2001.

YIN, R.K. Estudo de Caso - Planejame nto e Métodos. 3. ed. Porto Alegre: Bookman, 2005. 
APÊNDICE A - Atividades, métodos e cronograma de campo

\begin{tabular}{|c|c|c|c|c|c|c|c|c|c|}
\hline \multirow[b]{3}{*}{ Objetivo/Atividades } & \multirow[b]{3}{*}{ Métodos } & \multicolumn{8}{|c|}{ Cronograma Trimestral } \\
\hline & & \multirow{2}{*}{$\begin{array}{cc}2010 \\
1 & 2\end{array}$} & \multicolumn{2}{|r|}{2011} & \multicolumn{3}{|c|}{2012} & 2013 & \multirow{2}{*}{$\begin{array}{l}2014 \\
1516\end{array}$} \\
\hline & & & 3 & $\begin{array}{lll}4 & 5 & 6\end{array}$ & 7 & 8 & 910 & $\begin{array}{llll}11 & 12 & 13 & 14\end{array}$ & \\
\hline $\begin{array}{l}\text { 1. Análise da influência da rede de } \\
\text { cooperação nas cadeias de PFNM da RTM e } \\
\text { RSX }\end{array}$ & & & & & & & & & \\
\hline $\begin{array}{l}\text { Reuniões com instituições pra apresentação e } \\
\text { complementação do plano de ação do GT de } \\
\text { Atividades Produtivas }\end{array}$ & $\begin{array}{l}\text { Observação participante } \\
\text { apresentação e diálogo sobre } \\
\text { o plano; Entrevista não } \\
\text { estruturada sobre o GT de } \\
\text { Atividades Produtivas (Ideflor, } \\
\text { IFT, FVPP e ICMBio); }\end{array}$ & & & & & 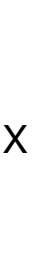 & & & \\
\hline
\end{tabular}




\begin{tabular}{|c|c|c|c|c|c|c|c|c|c|c|c|c|c|c|c|c|}
\hline & & 2010 & & 201 & & & & & 012 & & & & 13 & & & 014 \\
\hline Objetivo/Atividades & Métodos & 12 & 3 & 4 & 5 & 6 & 7 & 8 & 9 & 10 & 11 & 12 & 13 & 14 & & 16 \\
\hline Reuniões da Rede Terra do Meio & $\begin{array}{l}\text { Obeservação participante; } \\
\text { análise de documentos }\end{array}$ & & $x$ & & & & $x$ & & & & & & & & & \\
\hline Reuniões do GT de atividades produtivas & Observação participante; & & & & & & & & & & $x$ & & $\mathrm{X}$ & & $x$ & \\
\hline Reuniões do PDRS Xingu & $\begin{array}{l}\text { Observação Direta; Análise de } \\
\text { documentos }\end{array}$ & & & & & & & & & & & & & & & \\
\hline Projeto APL Terra do Meio - PNPSB & Observação participante & & & & & & & & $\mathrm{X}$ & & & & & $X$ & & $x$ \\
\hline $\begin{array}{l}\text { Reuniões e acompanhamento das atividades do } \\
\text { Selo de Origem do Xingu pelo Imaflora }\end{array}$ & Observação participante & & & & & & $x$ & $\mathrm{X}$ & $\mathrm{X}$ & $X$ & $x$ & $X$ & $x$ & $X$ & $x$ & \\
\hline
\end{tabular}




\begin{tabular}{|c|c|c|c|c|c|c|c|c|c|c|c|c|c|c|}
\hline \multirow[b]{2}{*}{ Objetivo/Atividades } & \multirow[b]{2}{*}{ Métodos } & 2010 & \multicolumn{3}{|c|}{2011} & \multicolumn{4}{|c|}{2012} & \multicolumn{4}{|c|}{2013} & \multirow{2}{*}{$\begin{array}{l}2014 \\
1516\end{array}$} \\
\hline & & 12 & 3 & 45 & 6 & 7 & 8 & 9 & 10 & 11 & 12 & 13 & 14 & \\
\hline $\begin{array}{l}\text { 2. Análise do funcionamento das principais } \\
\text { cadeias da Terra do Meio; }\end{array}$ & & & & & & & & & & & & & & \\
\hline $\begin{array}{l}\text { Estudo de custos das principais cadeias } \\
\text { produtivas em conjunto com o Imaflora - } \\
\text { castanha, borracha, copaíba e babaçu }\end{array}$ & Observação participante & $x \quad x$ & & & $x$ & & $x$ & & $x$ & & $\mathrm{X}$ & & $x$ & \\
\hline $\begin{array}{l}\text { Atividades de intercâmbio, treinamento, } \\
\text { acompanhamento, planejamento e melhoria na } \\
\text { Mini-Usina Rio Novo }\end{array}$ & $\begin{array}{l}\text { Observação participante; } \\
\text { Análise de documentos }\end{array}$ & & & & $x$ & & $x$ & & $x$ & & $x$ & & $x$ & \\
\hline $\begin{array}{l}\text { Treinamento Cadeia de Babaçu na } \\
\text { Transamazonica - Natura, GIZ, Cooperativas de } \\
\text { Cacau Orgânico, AASFLOR e Amoreri }\end{array}$ & Observação participante & & & & & & & & & & & $x$ & & \\
\hline $\begin{array}{l}\text { Reunião Natura, ISA, Imaflora, Amoreri e Amora - } \\
\text { aproximação dos atores locais e estruturação de } \\
\text { agenda conjunta }\end{array}$ & Observação participante & & & & & & & & & & & & $X$ & \\
\hline $\begin{array}{l}\text { Entrevista não estruturada Pedro Pereira } \\
\text { cantineiro da cadeia da copaíba }\end{array}$ & Entrevista não estruturada & & & & & & & $X$ & & & & & & \\
\hline $\begin{array}{l}\text { Entrevista com Francinaldo Lima - ISA - } \\
\text { estruturação dos processos de comercialização } \\
\text { da cadeia da copaíba }\end{array}$ & Entrevista não estruturada & & & & & & & & $x$ & & & & & \\
\hline
\end{tabular}




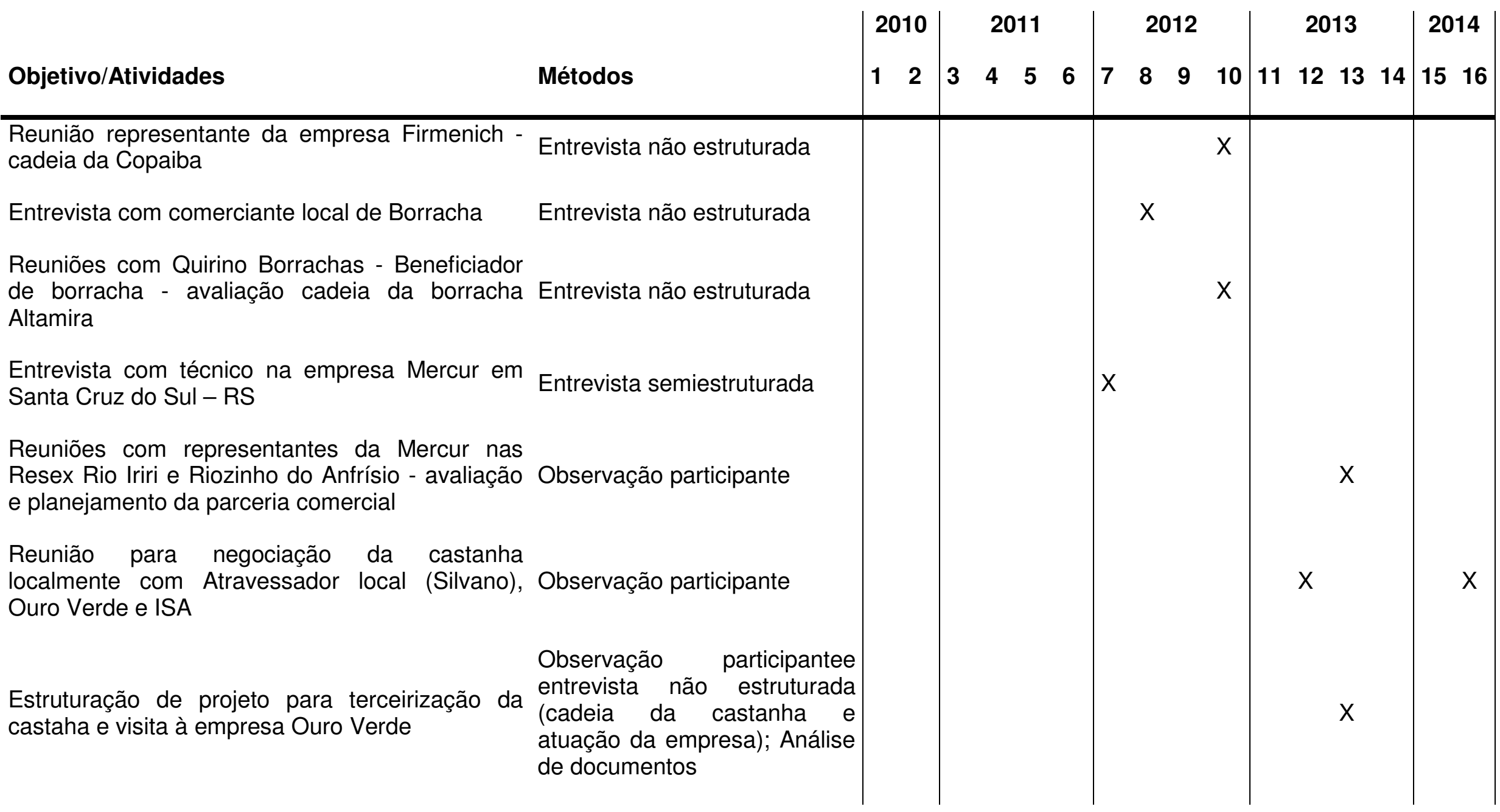


Objetivo/Atividades

Métodos

2010

2011

2012

2013

2014

Semana

do Extrativismo

avaliação

planejamento das cadeias de valor da Terra do

Meio - Comunidades, instituições de apoio empresas

Acompanhamento do processamento

de Observação direta; Análise de borracha na empresa Quirino Borrachas

documentos

\section{Análise dos processos de maturidade e} evolução das redes de PFNM na RTM;

Processo de Planejamento do GT de Atividades Produtivas da Rede Terra do Meio

Observação participante moderador do processo de planejamento

Observação participante

Reuniões com instituições pra apresentação e apresentação e diálogo sobre complementação do plano de ação do GT de Atividades Produtivas o plano; entrevista não estruturada sobre o GT de Atividades Produtivas (Ideflor, IFT, FVPP e ICMBio);

Reuniões do GT de Atividades Produtivas

Observação participante 


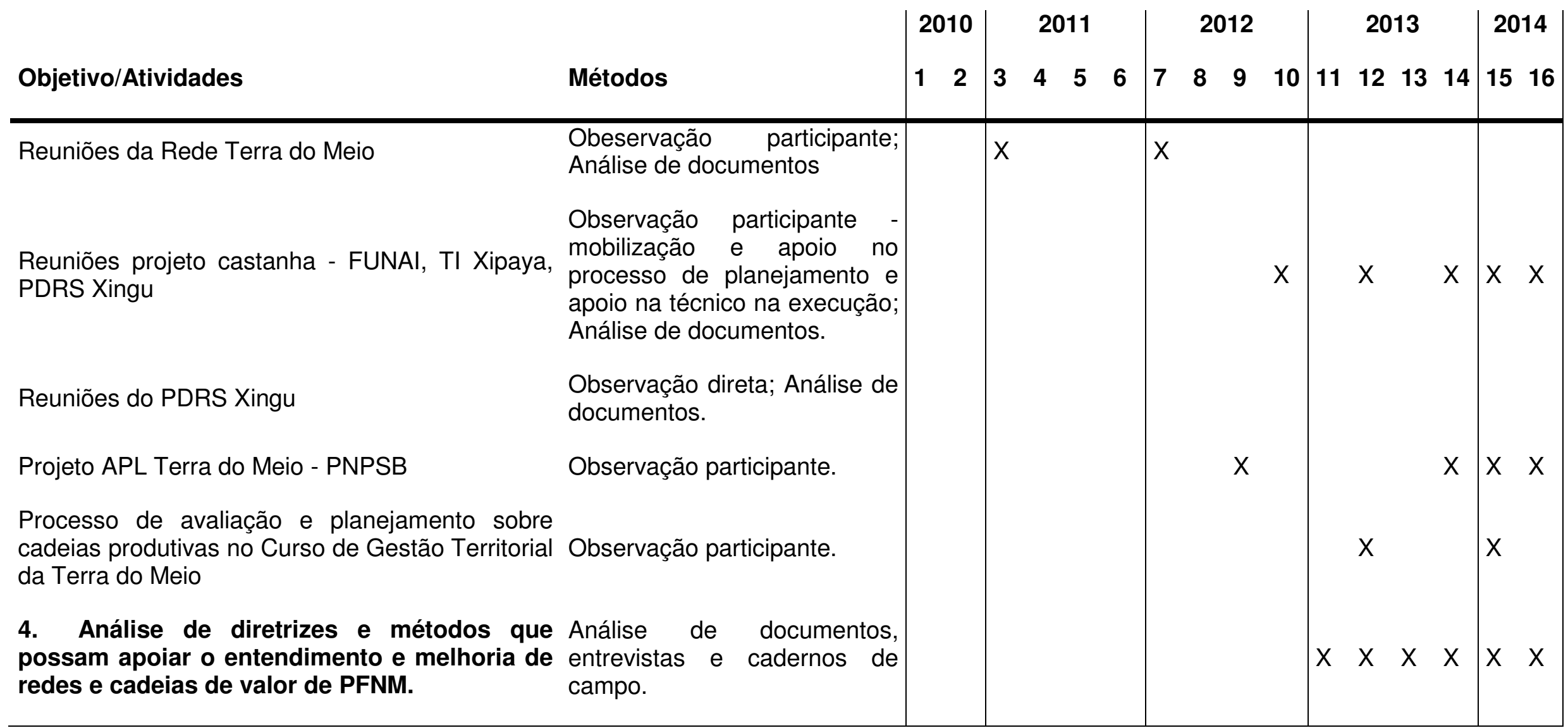

